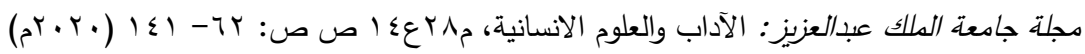 \\ DOI:10.4197/Art.28-14.3
}

\section{القول المبين في حكم الزكاة على المهنيين (') ؟ والضريبة عليهم كبديل؟ \\ تأصيل ودراسة}

$$
\begin{aligned}
& \text { المحامي د. عدنان بن جمعان الزهراني } \\
& \text { جدة - ش / صاري - حي البوادي }
\end{aligned}
$$

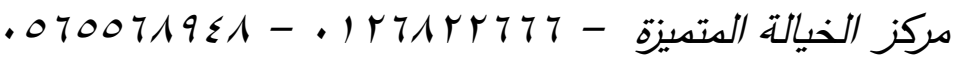

مستخلص. إن المنهج الذي اختاره ولاة الأمر في هذه البلاد حفظها الله، منهج جعل المرجعية في كل أعمالها لهالها

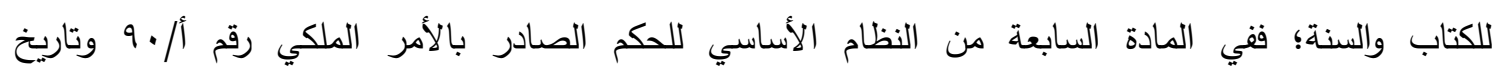

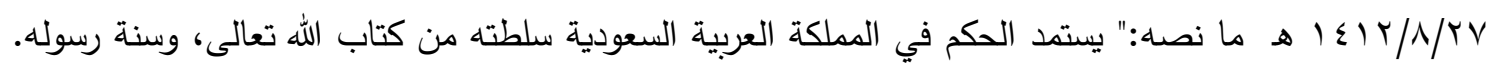

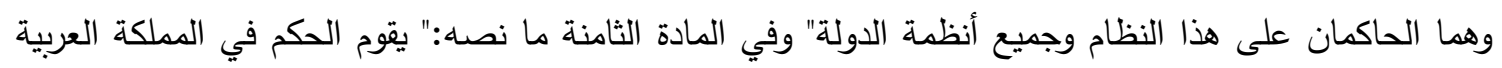
السعودية على أساس العدل والثورى والمساواة، وفق الثريعة الإسلامية"، وتأتي هذه الدراسة عملا بهذا المنهج،

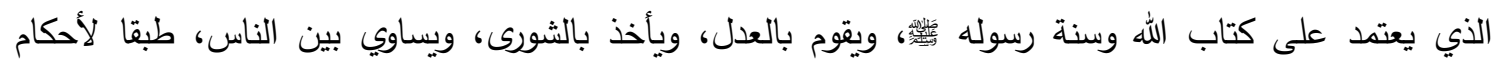

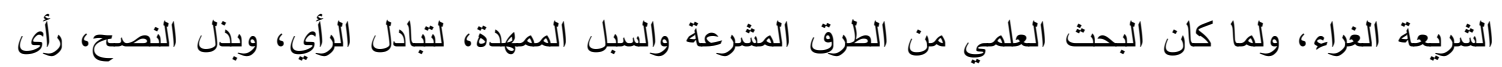

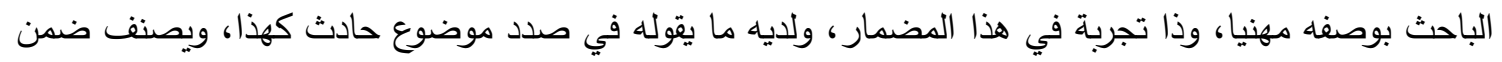

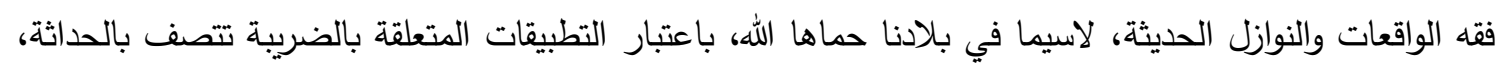

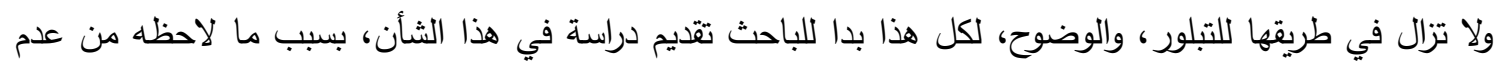

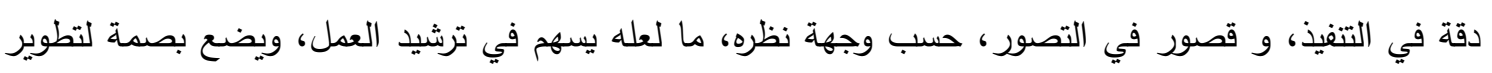

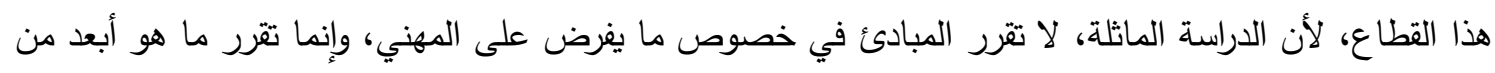

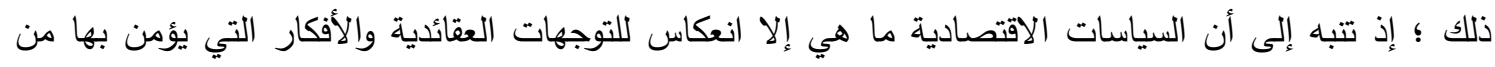

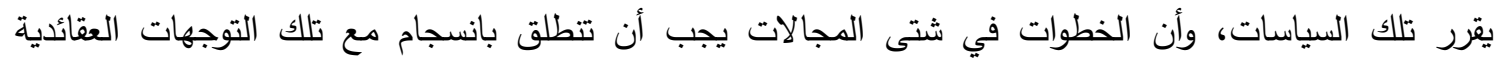

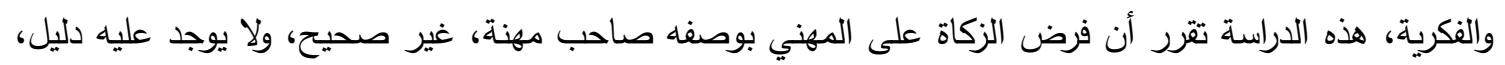


ولا قائل به في كل تراثا الفقهي، وأما فرض الضريبة على المهني فهو شيء سائغ، لا غبار عليه، ولكن بشروط

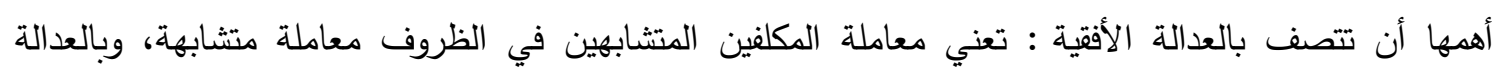

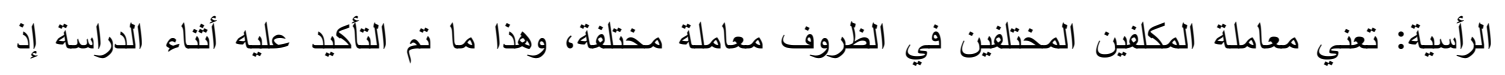

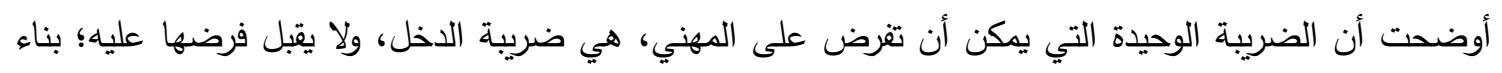

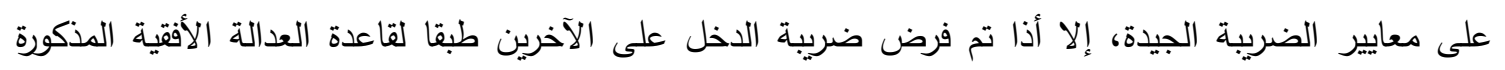

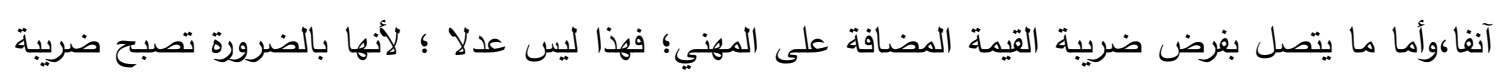

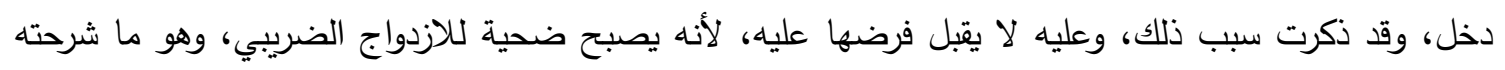
خلال الدراسة. وأنا إذ أقدم هذا البحث أقدمه نصحا لله تعالى ولرسوله وللأئمة المسلمين وعامتهم، سائلا الله تعالى أن يجعله خالصا لوجها الكريم. هذا وصلي الله وسلم وبارك على سيدنا محمد وآله وصحبه.

على الاستمرار دون تحقيق متطلبات جميع الأجهزة الحكومية، وهذا شيء له محاسنه الكبيرة، ولكنه في الوقت ذاته يعيق النشاط عن الاستمرار في حالة

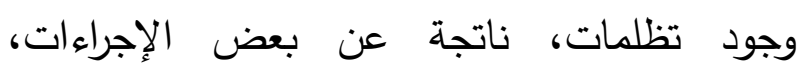
والمكلف يجد نفسه مضطرا للسير وراء متطلبات الجهة الحكومية، حتى بافتراض عدم صحة الإجراء

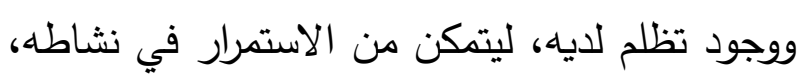

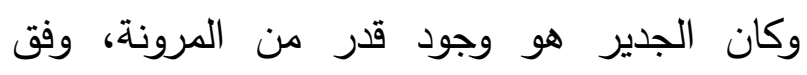
صلاحيات محددة، تتيح الاستمرار في النشاط، إلى ونى

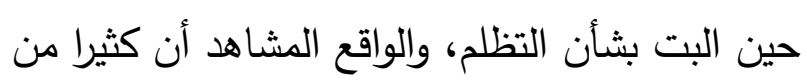

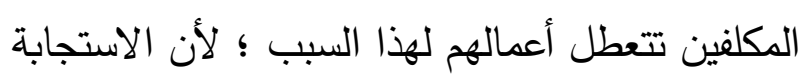
لتلك الإجراءات لا تكون متيسرة، وفق إمكانيات

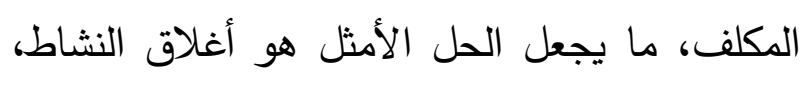

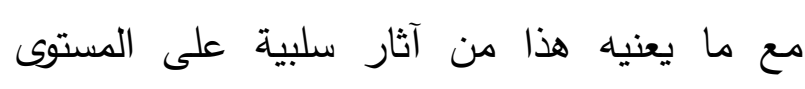
الاقتصادي، وهي خطوة يراها كثيرون أفضل من هن لنيه

\section{المقدمة}

بدأ في المملكة العربية السعودية تطبيق ضريبة

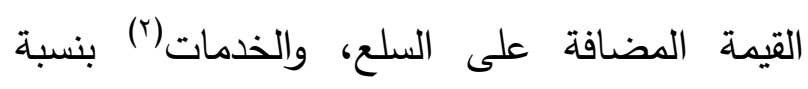

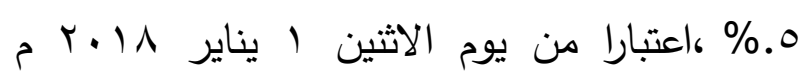

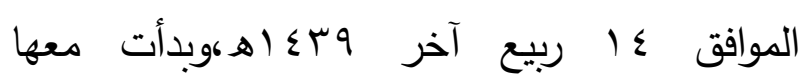
إجراءات تتطلب التسجيل، والتوقيع على الإقرار

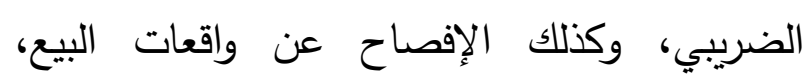

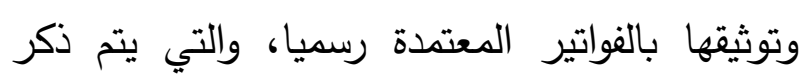
الرقم الضريبي فيها، وعهد ذلك إلى هيئة الزكاة

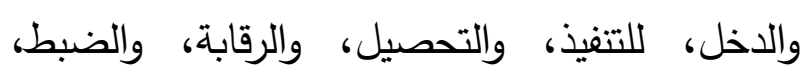

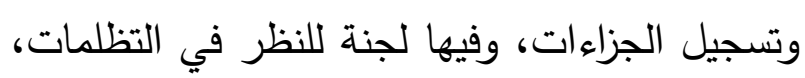
ما اقتضى تغييرا كبيرا في هيكلة الهيئة، وطريقة وتئة الجئة عملها، وتم ربط جميع الإجراءات الحكومية بعضها مع بعض، على نحو يجعل أي نشاط غير قادر الاجراه 
فيه أن يقوم بدوره في دعم الاقتصاد، وألا يكون عالة على المجتمع ؛ لأن الوطن بيتنا الكبير، ومتى أهمل وقع الجميع في العنت، ولحق الضرر بنا جميعا، وهذا الضرر قد لا يلاحظ لأول وهلة، ولكن لله عواقبه الوخيمة على المدى البعيد، إن تخلف المرء عن أداء دوره عبث لا يليق بعاقل، وجميع الثرائع أتت بعقاب من يتعمد العبث بمقدرات الأمة، أو يتجاهل دوره في القيام بوظيفته ودوره في خدمة مجتمعه، ولهذا على كل منا أن يقدم مساهماته بطيب نفس، وليعلم أن له من الأجر عند الله فوق ما يتصوره، لأن الله يكافئ على العمل الصالح الحسنة بعشر أمثالها، إن أية مساهمة تصب في مصلحة المجتمع ليست غرامة بل كرامة، وفرصة منحها الله للمكلف لمزيد من الخير، وما فتح عليه الله بهذا إلا ليخلف الله بأضعاف من الخير مضاعفة، ليس كلامي الآن عن الفرائض الثرعية فقط، وإنما هو حديث عن جميع المساهمات لمصلحة المجتمع، سواء ما فرضته الشريعة، أو فرضته السلطات، ولكن في الوقت ذاته، لابد من مراعاة عدة أمور، منها أن المساهمات لمصلحة الاقتصاد ليست تقتصر على المساهمات من خلال دفع الضرائب، هذا تصور قاصر، وفهم خاطئ، فالتاجر الكبير الذي رزق فطنة، وهو يدير أعماله على نحو حاذق ؛ يساهم في الاقتصاد على نحو كبير جدا، لأن تجارته الناجحة تعني وجود فرص عمل للآخرين، ووفرة في السلع، وتدوير للاقتصاد، ما لو تم تتبع أثره الاقتصادي
سلوك سبيل التظلم، لا سيما مع طول إجراءات التقاضي، فقد تتتهي السنة التكليفية، وتدخل غيرها، بل وتدخل ثالثة، ولم يفصل في التظلم الأول، وسيجد المكلف أن المنافع المرجوة من التظلم محدودة، أو لا جدوى منها، في الوقت الذي يكلفه الاستمرار بالنشاط مبالغ هو أحوج ما يكون إليها من أجل تطوير الأعمال واستمرارها، وهذا الأمر طال المهنيين؛ إذ صار تجديد ترخيصده، أو تجديد سجله، أو استقدام عمالة لصالح نشاطه، مرتبطا بسداد الضرائب، والحال أن الإجراء المطلوب هو سداد الزكاة مثلا، أو ضريبة القيمة المضافة، والحال أن كل ذلك مما لا يسوغ فرضها - حسب وجهة نظر الباحث(ז) - لا على المستوى الضربي طبقا لقواعد الضريبة، ولا على المستوى الثرعي طبقا لقواعد الزكاة وفقهها، وهنا تأتي أهمية هذه الدراسة، التي لم أجد من تعرض لموضوعها من قبل، برغم جدته وحيويته، وفائدته. وأستبق فأقول: لا يسع المرء إلا أن تكون لله مساهماته في الاقتصاد الوطني، ولا يجوز لله أن يولي ظهره قبل ذلك، ويجب وجوبا شرعيا لا مرية

(T) - يحتفظ الباحث بأقصى درجات الود ، و العرفان لاى وجود آراء أخرى ، فكلها محل تقديره ، غير أن حفظ ذلك لا بل بعني عدم توضيح

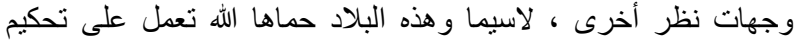

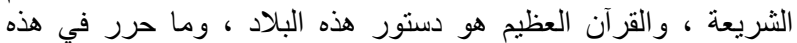

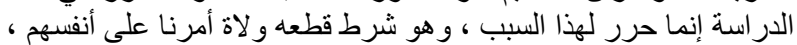

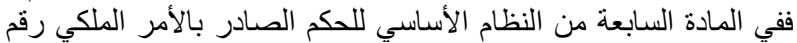

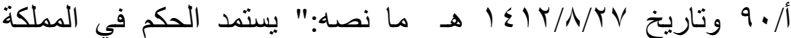

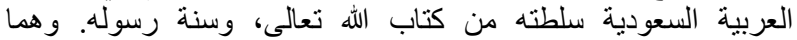

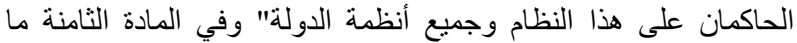

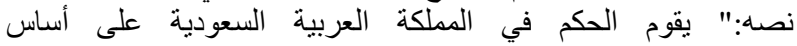
العدل و الثورى و المساو اة، وفق الثريعة الإسلامية". 
الاقتصاد لا يمكن أن نتجاهلها، فهي مساهمة مباشرة، وفورية، وليست تفتقر لغير بدء العمل ؛ لتبدأ مساهته لمصلحة الاقتصاد، فهو بصفة دائمة نافع للاقتصاد، وليس عالة عليه، وما يجنيه من أجر لرانه

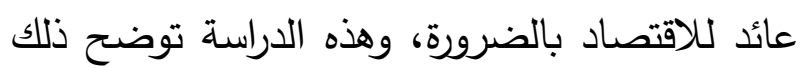
بجلاء، فالطبيب مثلا في عيادته، والمستشار في مكتبه، كل منهما يضيف لجهة عميله ما يزيد من

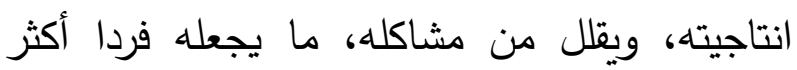

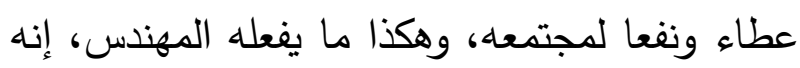
يبني أو يصلح، أو غير ذلك من الأعمال التي

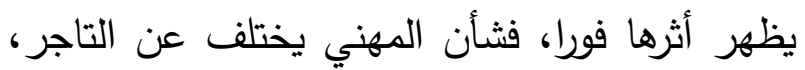

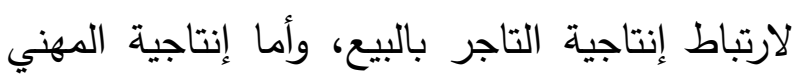
فتحقق بالخدمة، كما توجد جوانب أخرى لابد من إنابه بيانها تفصيلا خلال الدراسة. ولما كانت الدراسة تتعلق بالزكاة، وببديلها "الضريبة"، كان لابد من جعلها في فصلين، أحدهما عن الزكاة، والآخر عن الضريبة، وفي كل من الفصلين كان

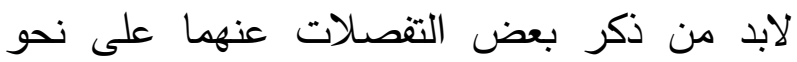

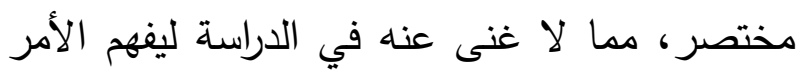

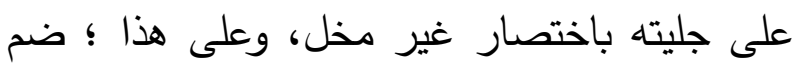

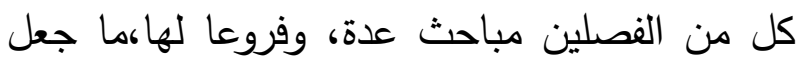
فصول الدراسة ومباحثها تظهر على هذا النحو:

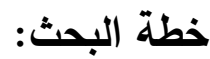
الفصل الأول: تعريف الزكاة، أركانها، وشروطها، والأموال التي تجب فيها.

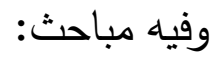

لوجد بدرجة لعلها لا تقل عن الضرائب التي تثرض

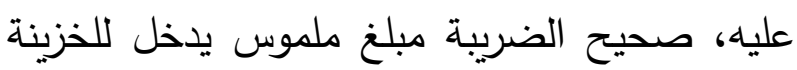
العامة، ومساهمة التاجر من خلالها مساهمة محسوبة مباشرة، ولكن الأمر ليس بهذه البساطة

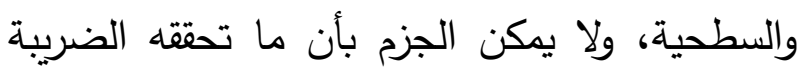
للخزينة العامة من خلال الضريبة، وبالتالي ما لهال يتحقق لمصلحة الاقتصاد الكلي، نعم لا يمكن الجزم

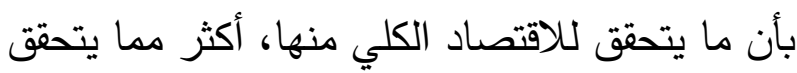

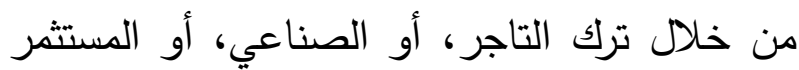
بصفة عامة، دون فرض هذه الضريبة عليه، إن تقريرا يصب لصالح إحدى الوجهتين يفتقر لدراسات

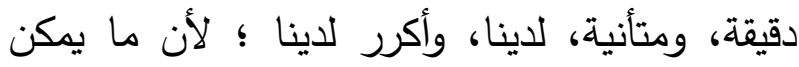
رصده من آثار في بلد، ليس بالضرورة هو ما يمكن لان لاندرن

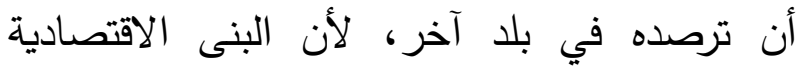

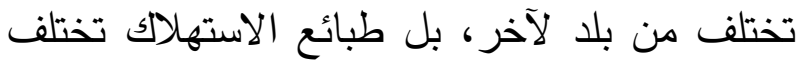
من بلد لآخر، ما يعني أنك في حاجة ماسة لدراسة تخص المملكة العربية السعودية، ولا يكفي استنساخ لهاخ تجارب البلاد الأخرى، وليس ما يدخل للخزينة العامة من جهة الضريبة هو بالضرورة نافع للاقتصاد الكلي

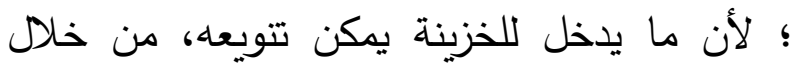
توسيع القاعدة الاقتصادية، والاخول في نشاطات جديدة صناعية، وتجارية، لها أثرها البالغ في تشغيل

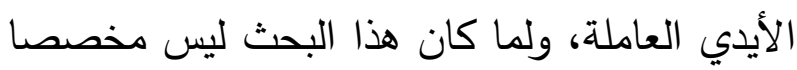
للحديث عن الجوانب الاقتصادية بصفة عامة، برغم صلته الوثيقة بها، وإنما يركز الكلام عما يخص الكس الهن المهنيين ؛ عليه أفيد بأن مساهمة المهني لمصلحة 
الفرع الثاني: منطلقات الضرببة من خلال فلسفة الدولة العقائدية والاقتصادية.

أولا: النظام الإقطاعي.

ثانيا: النظام الرأسمالي.

ثالثا: النظام الثيوعي.

رابعا: النظام الاشتراكي.

خامسا: النظام المختلط.

سادسا: النظام الإسلامي.

الفرع الثالث: أنواع الضرائب.

الفرع الثالث: وظائف الضريبة، وشروطها.

$$
\text { أولا: وظائف الضريبة. }
$$

ثانيا: قواعدها أو شروطها.

الفرع الرابع: حكم الضريبة شرعا.

الفرع الخامس: وكيف ينبغي أن تكون الضربية على المهني باعتبارها بديلا للزكاة.

المبحث الثالث: الفرق بين الضربية والزكاة.

ثم آتي على ذكر الخاتمة وأهم النتائج.

وأما عن منهجي في الدراسة فهو منهج استقصائي، مع الحفاظ على جانب الاختصار والتركيز، كما أن منهجي في تخريج الأحاديث أني أكتفي بالصحيحين حين يكون الحديث فيهما، فإن لم يكن فإني أخرجه من أهم المصادر، وأذكر خلاصة الحكم عليه، من جهة الصحة، والضعف نقلا عن أحد أئمة هذا الشأن، وأما الأقوال الفقهية فسأذكرها معزوة إلى الى أصحابها من كتبهم المعتمدة، مكتفيا بالمذاهب الأربعة، ولا أخرج عن ذلك إلا يسيرا، من دون
المبحث الأول: تعريف الزكاة،المبحث الثاني:

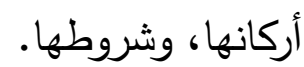

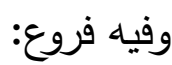
الفرع الأول : شروط باذل الزكاة. الفرع الثاني : شروط آخذ الزكاة. الفرع الثالث: شروط المال المزكى. وفيه مسائل: المسألة الأولى: استقرار الملك. المسألة الثانية: خروج المال عن دورته الاقتصادية

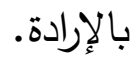
المبحث الثالث: الأموال التي تجب فيها. الفصل الثاني: تعريف المهني، وإمكانية تخريج المهنة طبقا لفقه الزكاة، وأقوال الفقهاء بشأنه، ومتى تجب عليه الزكاة، ومدى جواز فرض الضربية عليه، والفرق بين الضريبة والزكاة. وفيه مباحث: المبحث الأول: تعريف المهني. المبحث الثاني: إمكانية تخريج المهنة طبقا لفقه الزكاة، وأقوال الفقهاء في المسألة، ومتى يزكي

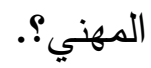
المبحث الثالث: فرض الضريبة على المهني بدلا من الزكاة، تعريفها، ومنطلقاتها العقائدية، وأنواعها، ووظائغها، وحكمها وكيف ينبغي أن تكون على

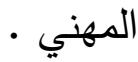

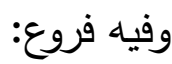
الفرع الأول: تعريف الضربية. 
قال ابن فارس :"والأصل في ذلك كله راجع إلى الى هذين المعنيين، وهما النماء والطهارة"(£). وقال في لسان العرب :"وأصل الزكاة في اللغة:

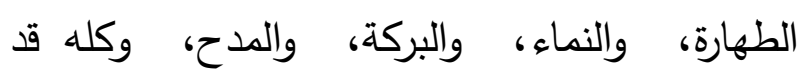

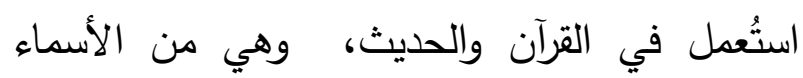

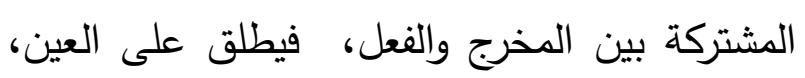

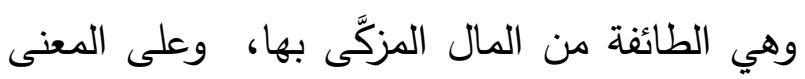
وهي التزكية"(0). وقال الراغب في المفردات: "أصل الزكاة النمو الحاصل عن بركة الله تعالى، ويعتبر ذلك بالأمور

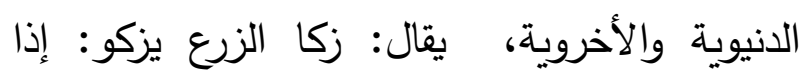

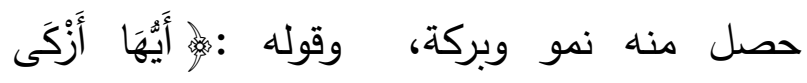

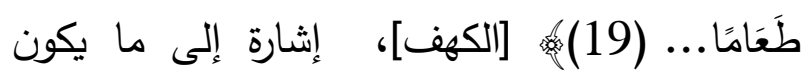

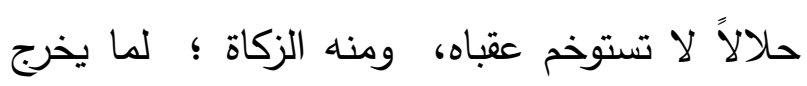

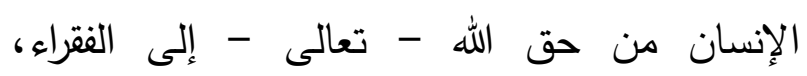

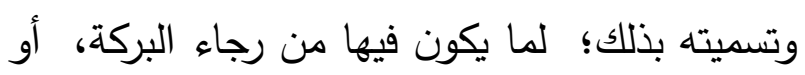

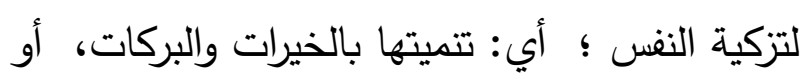
لهما جميعًا؛ فإن الخيرين موجودان فيها، وقرن الله

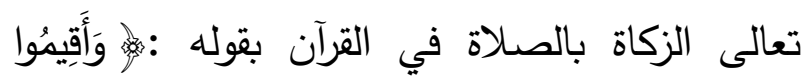

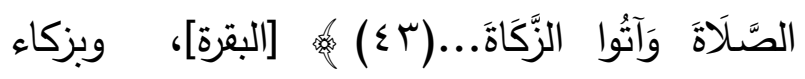
النفس وطهارتها ؛ يصير الإنسان بحيث يستحق في

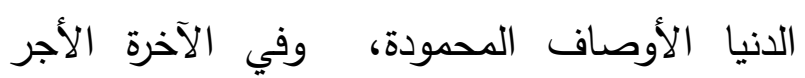

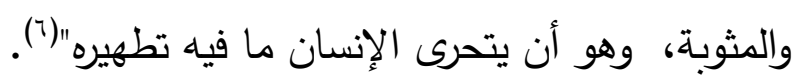

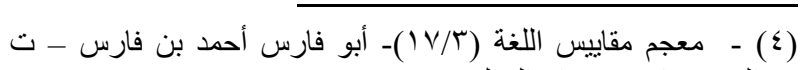

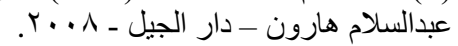

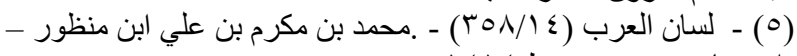

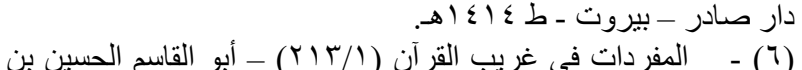

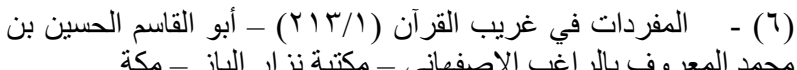

الاستقصاء، غير أني سأرجح في بعض المسائل

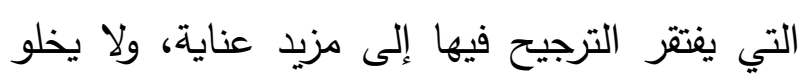

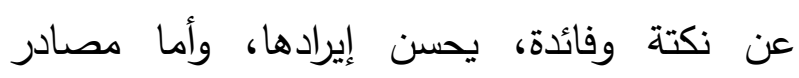

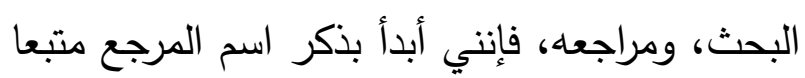

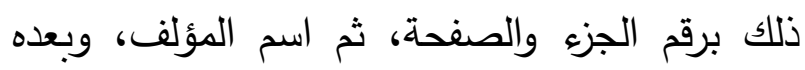

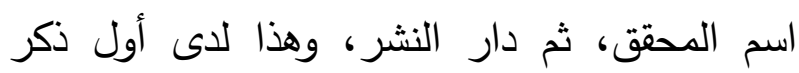

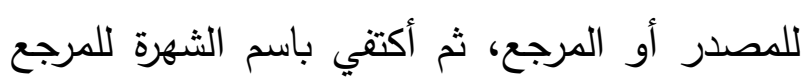

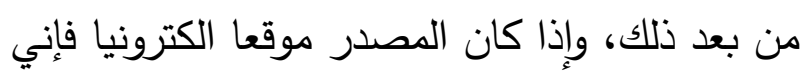

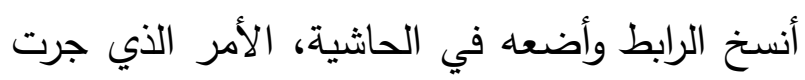

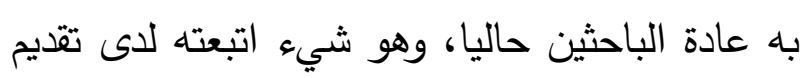
بحثي للدكتوراه في جامعة أم القرى بعنوان : أحكام

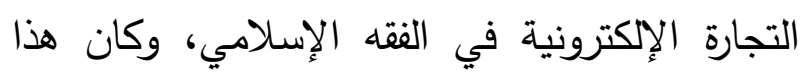

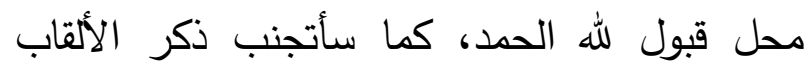
العلمية كما هي العادة في البحوث المُحَكَّمة. وهذا صلي اللهم وبارك على نبيك محمد وآله

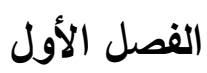
تعريف الزكاة أركانها وشروطها والأموال التي تجب فيها توناه المبحث الأول: تعريف الزكاة أولًا: الزكاة لغة: تطلق الزكاة في اللغة على معنيين: الأول :النماء والبركة والزيادة. الثاني :الطهارة. 
r. الحرية، ولا يكاد يقع في هذا خلاف أيضا(r') .

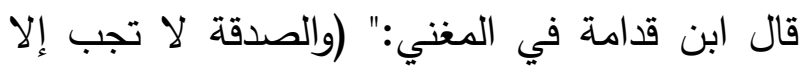

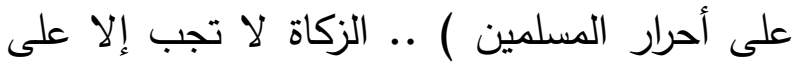

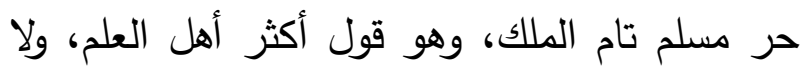
نعلم فيه خلافا، إلا عن عطاء، وأبي ثور ؛ فإنها قالا: على العبد زكاة ماله"("ir).

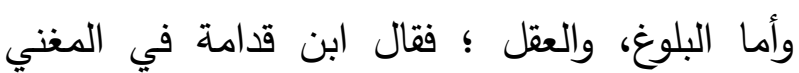
:"مسألة : قال : (والصبي، والمجنون ؛ يخرج عنهما

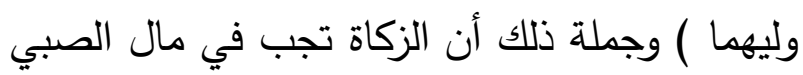
والمجنون ؛ لوجود الشرائط الثلاث فيهما، روي ذلك اهن عن عمر، وعلي، وابن عمر، وعائشة، والحسن بن علي، وجابر رضي الله عنهم. وبه قال ...مالك عل ...

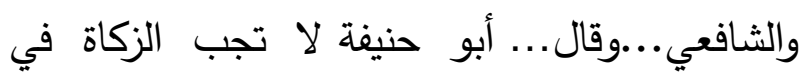
أموالهما ـ وقال أبو حنيفة:يجب العشر في زروعهما، وثمرتهما، وتجب صدقة الفطر عليهما.واحتج في نفي الزكاة بقوله

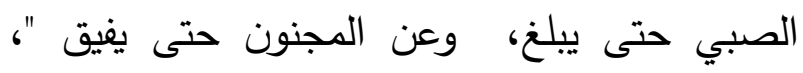
وبأنها عبادة محضة ؛ فلا تجب عليهما، كالصلاة

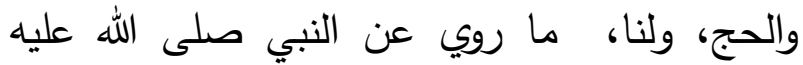

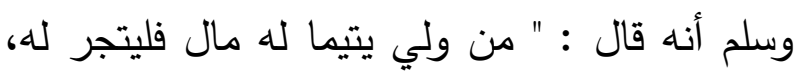

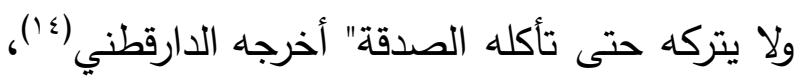

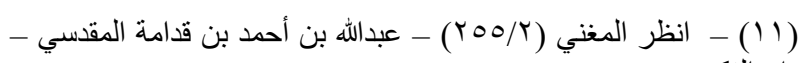

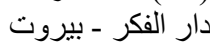

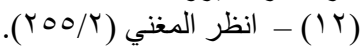

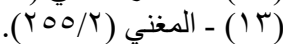

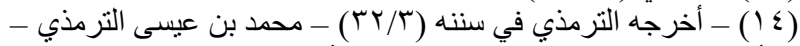

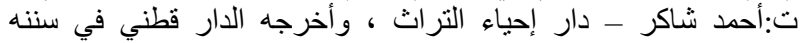

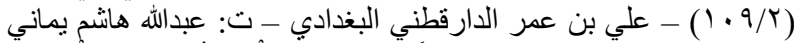

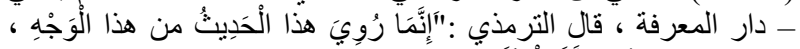

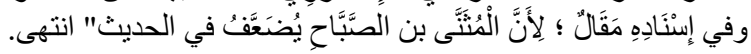

ثانيًا: الزكاة في الاصطلاح: عرف الحنفية الزكاة بقولهج: "تمليك جزء من مال، عيَّنَه الشارع، من مسلم فقير غير هاشمي ولا مولاه، بشرط قطع المنفعة عن الملك من كل وجه" (V) وعرفها المالكية : "إخراج جزء مخصوص، من من مال

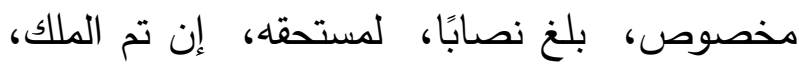
وحال الحول"(^). مخوصن وعرفها الثافعية بأنها: "اسم صريح لأخذ شيء

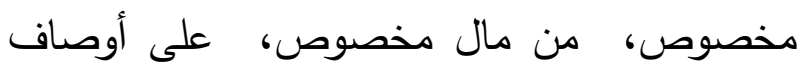

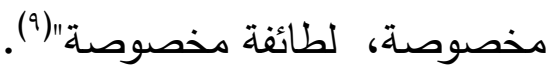
وعرفها الحنابلة بأنها: "حق واجب في فوطه مال

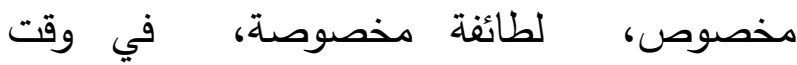
مخصوص" (1) (1) وكلها معان متقاربة. المبحث الثاني:أركانها وشروطيها. الأركان هي :باذلها، وآخذها، والمال المزكى.

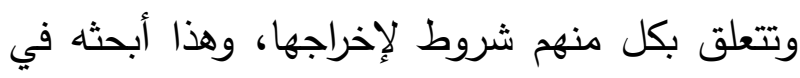

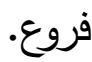
الفرع الأول : شروط باذل الزكاة.

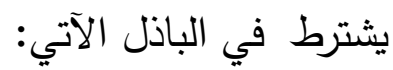
1. الإسلام، بلا خلاف (').

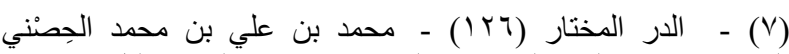

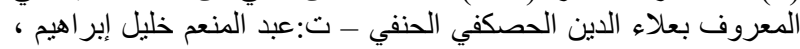

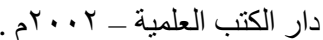

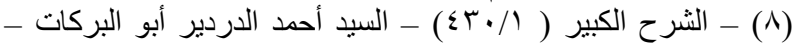
ت:محمد عليش - دار الفكر - بيروت. (9) - المجموع شرح المهذب (YMN/0) - أبو زكريا يحيى بن شرف

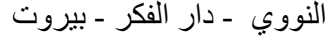

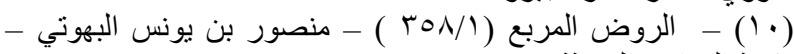

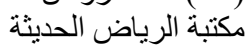


يقصد بآخذها (مستحقوها) وهم: من قام بهم سبب

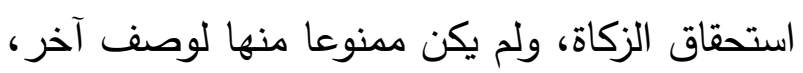
وهذه هي "مصارف الزكاة"، وفي هذا يقول تعالى:

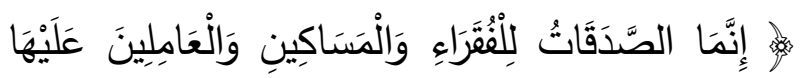

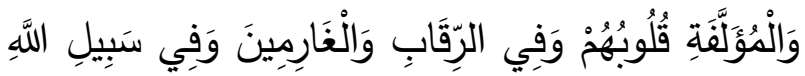

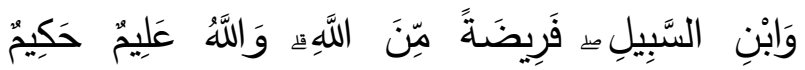

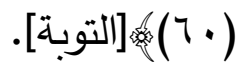
فمن قام به وصف من تلك الأوصاف استحق من

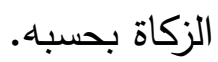
ونختصر القول بشأن تلك الأصناف على النحو الآتي:

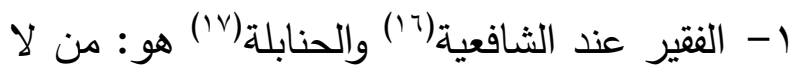
يجد شيئا من الكفاية، أو يجد بعض الكفاية، أي: دون نصفها.

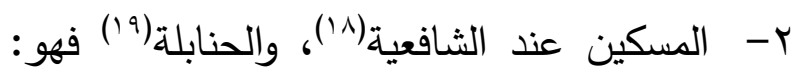
الذي يجد أكثرها، أي: أكثر الكفاية، أو نصفها، والحنفية(·r) والمالكية(r) على اكترها: عكس ذلك فيهما. ورجح الطبري في تفسيره: أن المراد بالفقير : المحتاج المتعفف الذي لا يسأل، والمسكين: المحتاج المتذلل الذي يسأل، وذكر وجه ذلك ؛ قال :"وأولى هذه

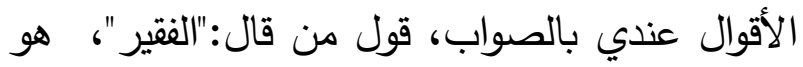
ذو الفقر أو الحاجة، ومع حاجته يتعفّف عن مسألة

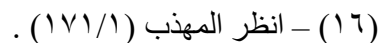

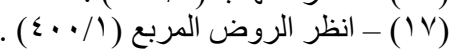

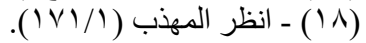

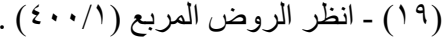

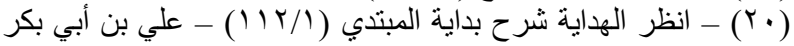
المر غيناني - المكتبة الإسلامية. (Y) - انظر الخرشي على سيدي خليل (Y/Y) الخرشي - - مار الفكر
وفي رواته المثنى بن الصباح، وفيه مقال، وروي

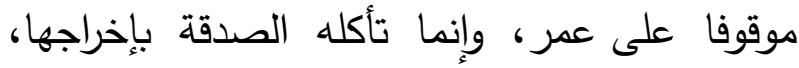

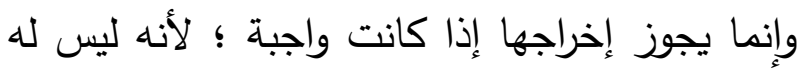

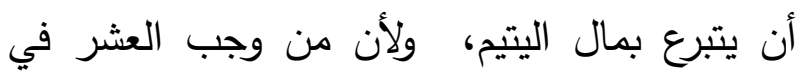

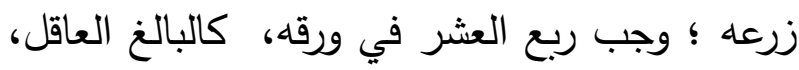

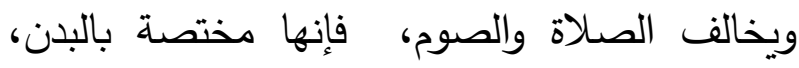
ونية الصبي ضعيفة عنها، والمجنون لا يتحقق منه

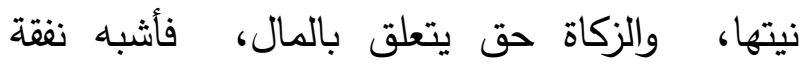

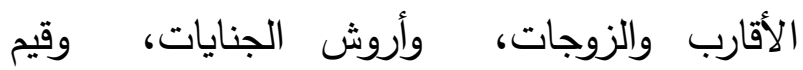

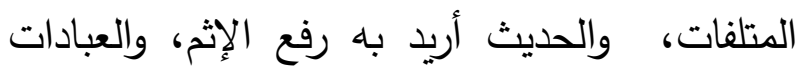

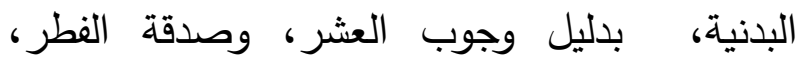
والحقوق المالية، ثم هو مخصوص بما ذكرناه، والزكاة في المال في معناه، فنقيسها عليه، إذا تقرر هذا، فإن الولي يخرجها عنهما من مالهما ؛ لأنها

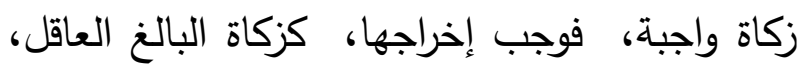

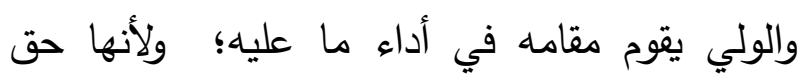

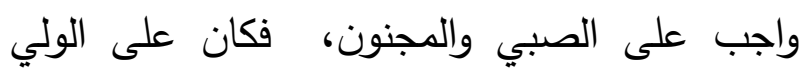
أداؤه عنهما، كنفقة أقاربه، وتعتبر نية الولي في

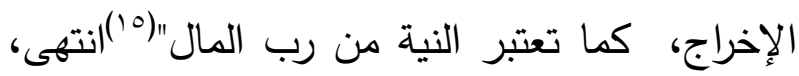
وسيأتي تحقيق القول في هذا لاى الحديث عن الركن

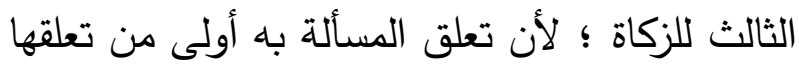
بياذلها، وسيأتي مزيد بيان لهذا. الفرع الثاني: شروط آخذ الزكاة. 
هذا ولا يترتب على التفريق بينهما كبير شأن، ففي كل تقدير يعطى من قام به أحد الوصفين، ما يقوم بحاجته، ويحقق لله كفايته مع من يعول مدة عام،

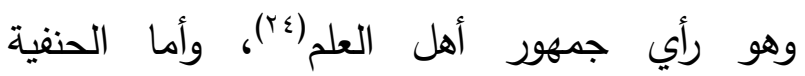
فيجيزون العطاء لهما بقدر لا يخرجهما عن حد الاستحقاق ؛ لأن الدفع وقع لوصف فلا يعطى قدرا يخرجه عنه(ror)، وقال ابن حزم :"يُعطى من الزكاة

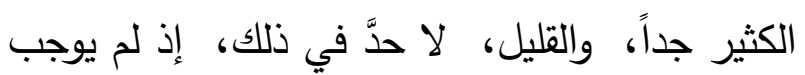
الحدَّ في ذلك قرآنٌ ولا سنةُّ"( بr). والبحث ههنا ليس مخصصا لتفصيل القول حيال كل ما سبق، فتكفي الإشارات. r- العاملون عليها فهم :"السعاة في قبضها من بن أهلها، ووضعها في مستحقِيها، يعطون ذلك

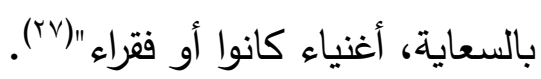
قال ابن جرير الطبري :"ثُّ اختلف أهل التأويل في قدر ما يعطى العامل من ذلك، فقال بعضهم: يعطى

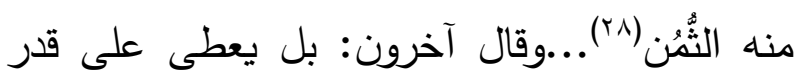

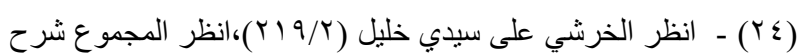

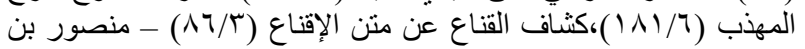

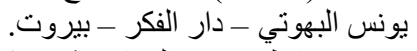

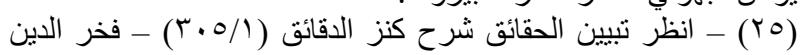

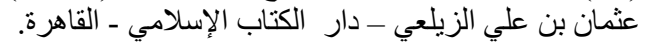

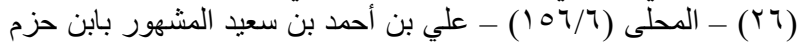

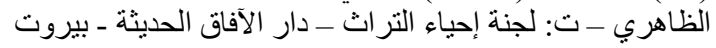

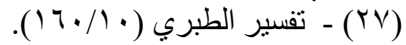

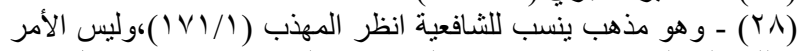

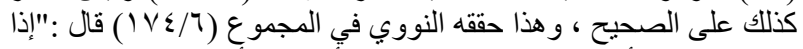

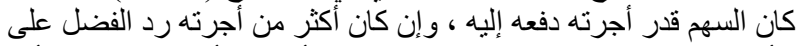

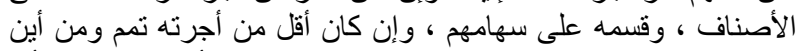

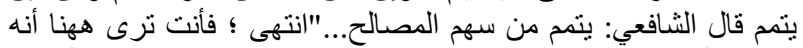

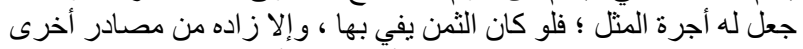

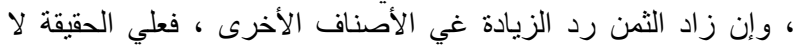
خلاف مع الجمهور ههنا.
الناس والتذلل لهم، في هذا الموضع و" المسكين"هو

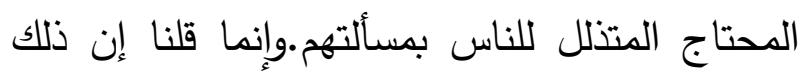

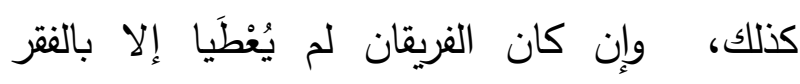

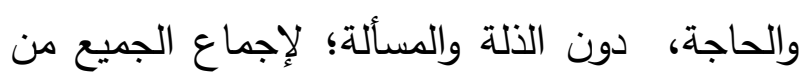

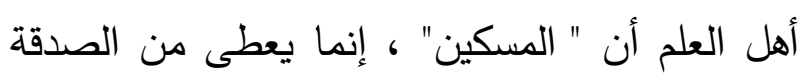

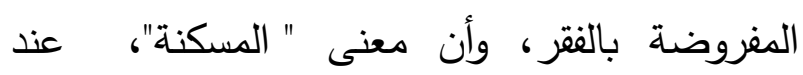

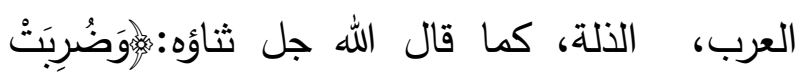

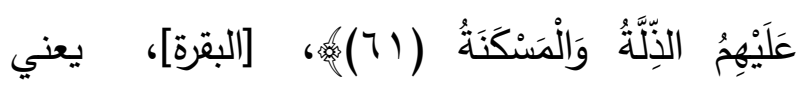
بذلك: الهون والذلة، لا الفقر ، فإِذا كان الله جل ثناؤه قد صنَّف من قسم له من الصدقة المفروضة قسما لهان

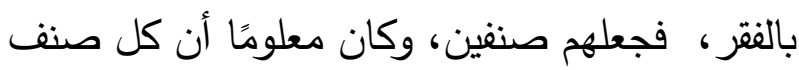

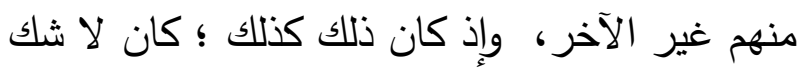

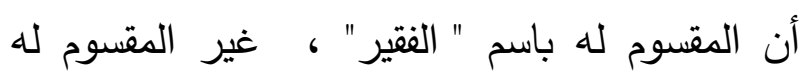

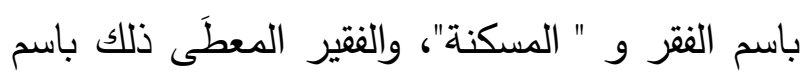

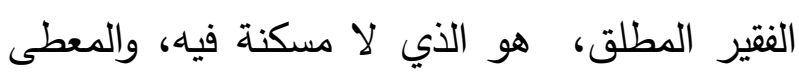

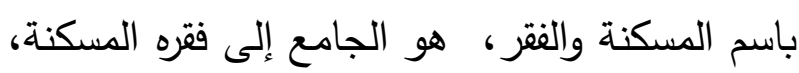

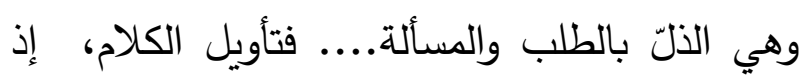
كان ذلك معناه: إنما الصدقات للفقراء: المتعِّف ولفِ منهم الذي لا يسأل، والمتذلل منهم الذي يسأل"(Yr)؛

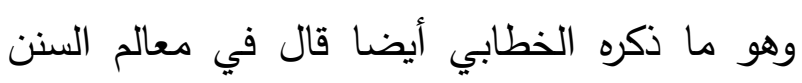

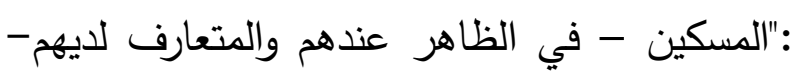

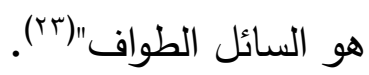

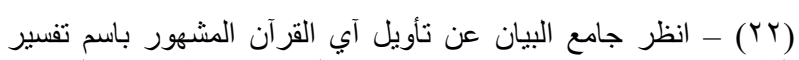

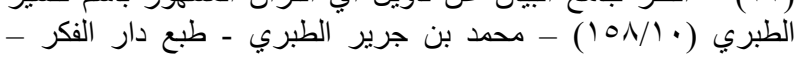

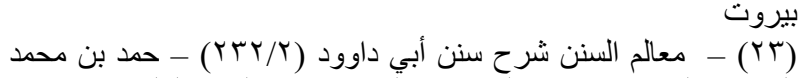

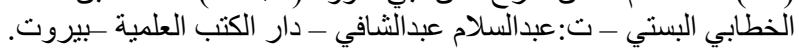


ففقال: هو إنْ شَاءَ، ولم يُنْكِزْ عليه ما فَعَلَ ؛ فَانْعَقََ الْإِجْمَاعُ عليه" (rr).

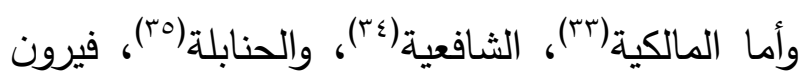
أن هذا السهم غير ساقط، ويصرف بحسب اجتهاد الإمام، فمتى وجدت حاجة إليه فله أن يصرفه في هذا الوجه. وقال ابن جرير الطبري :"الصواب من القول في ذلك عندي: أن الله جعل الصدقة في معنيين:

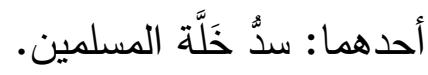
والآخر : معونة الإسلام وتقويته. فما كان في معونة الإسلام وتقوية أسبابه ؛ فإنه يُعطاه الغني والفقير؛ لأنه لا يعطاه من يعطاه

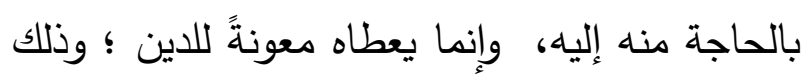
كما يعطى الذي يُعطاه بالجهاد في سبيل الله، ؛ فإنه

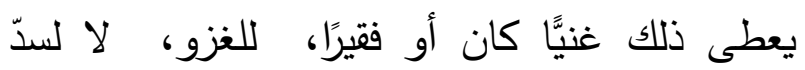

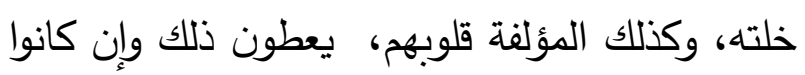
أغنياء؛ استصلاحًا بإعطائهم أمرَ الإسلام وطلب تقويته وتأييده، وقد أعطى النبي صلى الله عليه وسلم من أعطى من المؤلفة قلوبهم، بعد أن فتح الله عليه

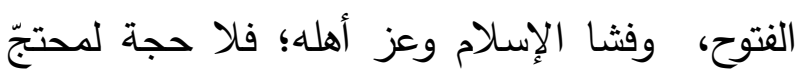

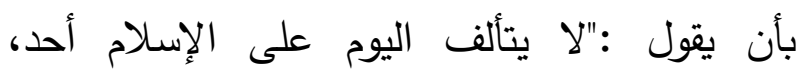

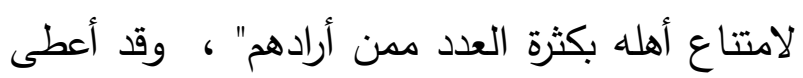
النبي صلى الله عليه وسلم من أعطى منهم في الحال

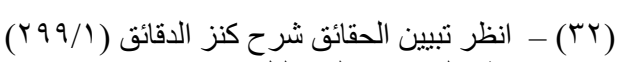

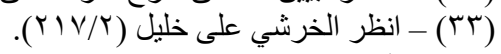

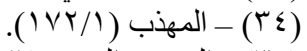

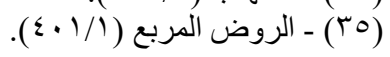

عُمالته(rq)....قال أبو جعفر : وأولى الأقوال في ذلك

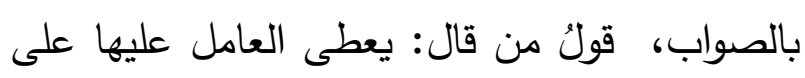

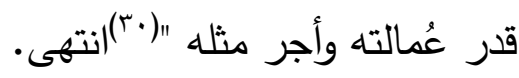
ع- المؤلفة قلوبهم فهم:" جمع مؤلف وهو مثله السيد

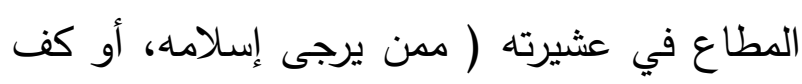

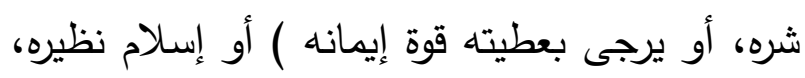
أو جبايتها ممن لا يعطيها .."( (r). وذهب الحنفية إلى أن سهم المؤلفة قد سقط، قال

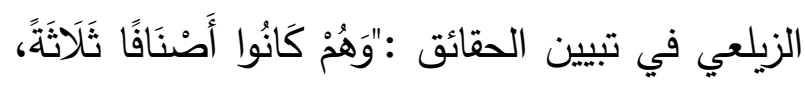

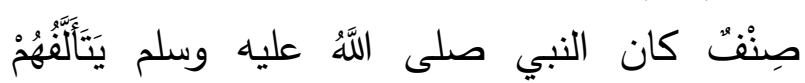

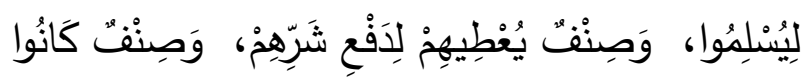

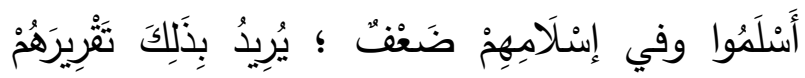

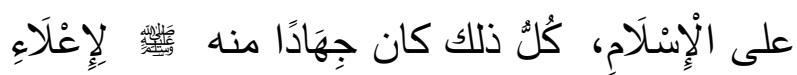

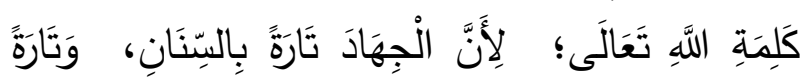

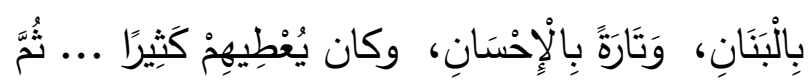

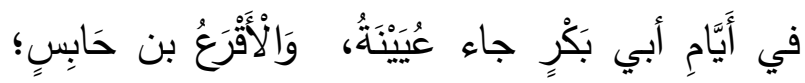

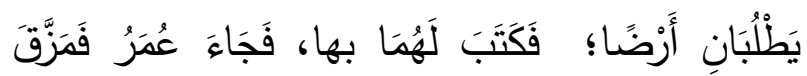

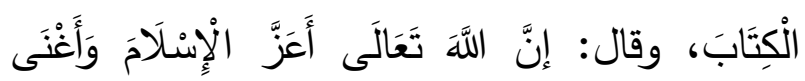

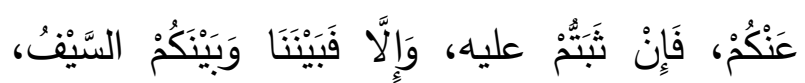

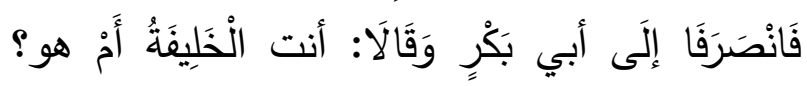

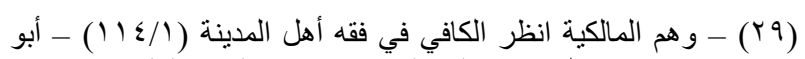

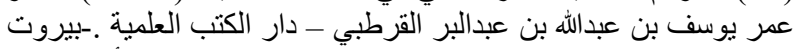

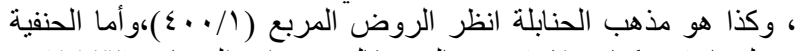

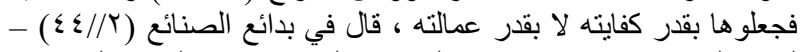

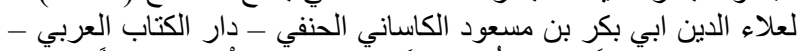

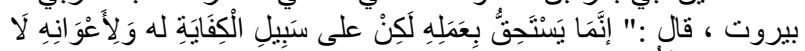

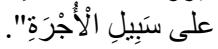

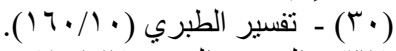

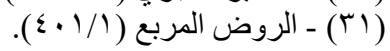


^- ابن السبيل: المسافر المنقطع بسفره المباح أو

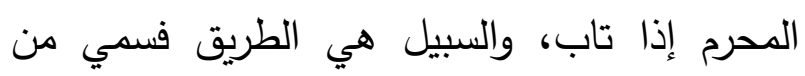

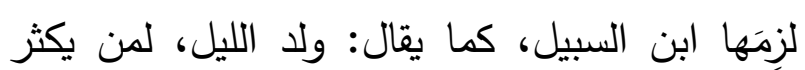

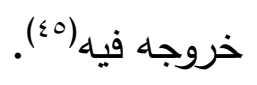

فيعطى ابن السبيل ما يوصله إلى بلده.

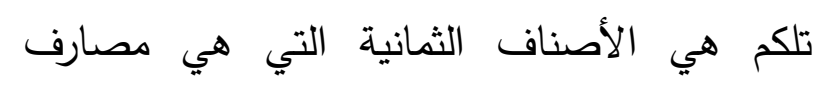
للزكاة، وكل صنف من الأصناف، يدفع إليه ما هاتهيه

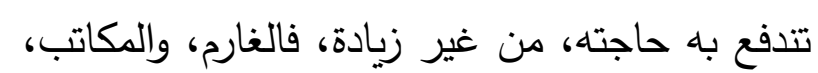

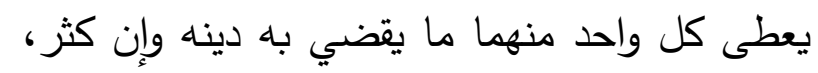

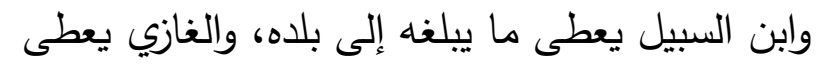

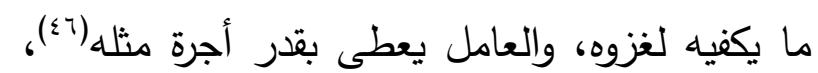

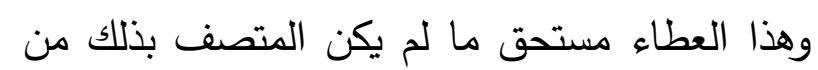

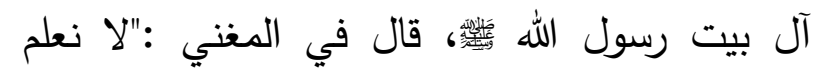
خلافا في أن بني هاشم لا تحل لهم الصدة لهات

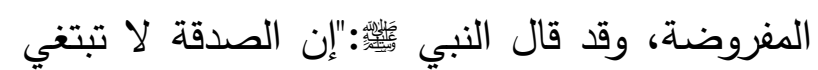

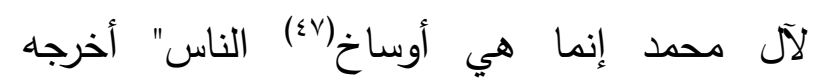
مسلم(^)، وعن أبي هريرة قال: أخذ الحسن تمرة من الهن

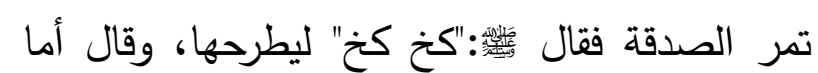

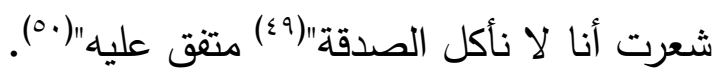

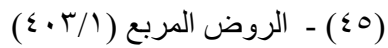

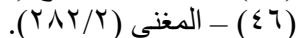

و (\&V)

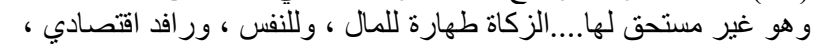

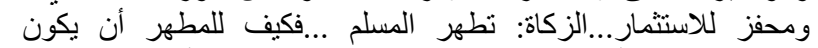

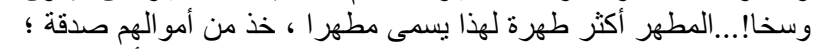

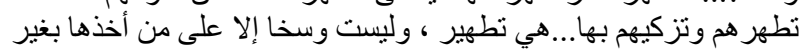
حثى. (s)

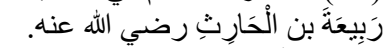

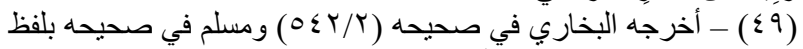

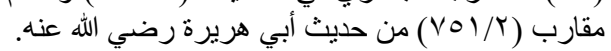

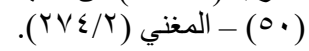

التي وصفت"(זr) انتهى ؛ وهو كلام نفيس جدير بأن يحفظ. 0- - الرقاب وهم المكاتَبون (rv)، يعطون منها في فك قال أبو جعفر الطبري : "عنى بالرقاب، في هذا

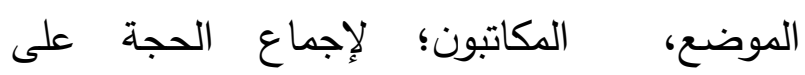

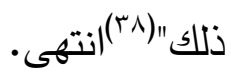
צ- الغارمون: جمع غارم، قال في لسان العرب: "الغرم: الدين، ورجل غارم: عليه دين، ...قال الزجاج الغارمون هم الذين لزمهم الدين في الحمالة وقيل هم الذين لزمهم الدين في غير معصية"(99).

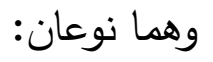

أحدهما: غارم لإصلاح ذات البين فيعطى منها

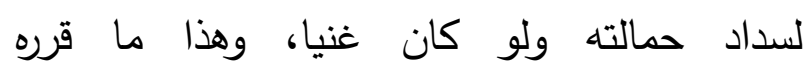

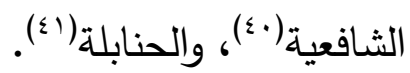
الثاني: من وقع في دين لا عن معصية إلا أن يتوب، وهو قول المذاهب الأربعة(؟r).

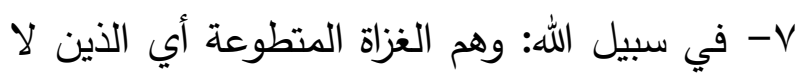
ديوان لهم أو لهم دون ما يكفيهم فيعطى ما يكفيه

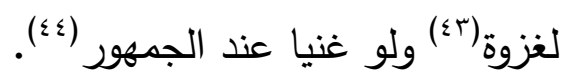

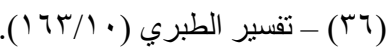

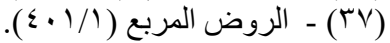
( )

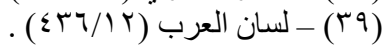

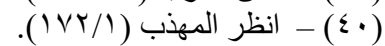

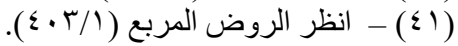

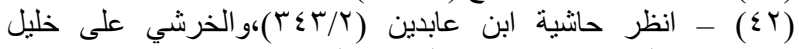

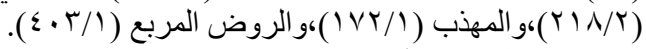

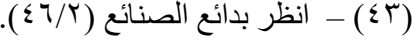

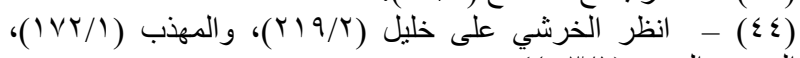

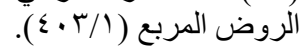


وقاعدة هذا الباب ظاهرة من تعريفه، فمتى ملك

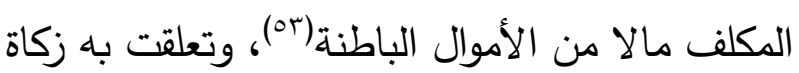

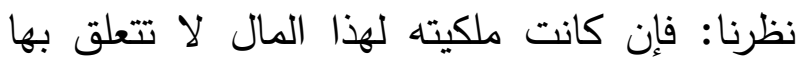
حقوق للغير ؛ زكاه، وإلا نظرنا إلى ما تعلق به فإن

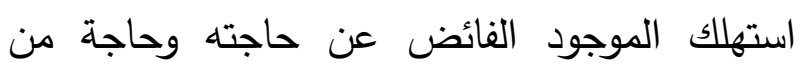
يمونه، فلا شيء عليه، وأن لم يستهلك الموجود فيزكى بقدر ما يفيض عن حاجته وحاجة من يمون ويقضي الحق الذي عليه. وإنما اقتصرت على ذكر الأموال الباطنة دون الظاهرة ؛ لأن الظاهرة وهي السائمة من بهيمة الأنعام، والزروع والثثار ، والمعدن، تتعلق فيها الزكاة بعين المال هذا في الأصل، وهو محل اتفاق أهل ولتون

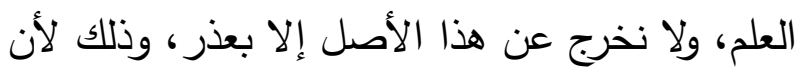
العين حاضرة وظاهر وجودها، وتحصيل الزكاة فيها

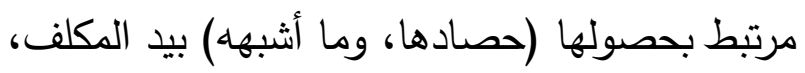
والديون متعلقة بالذمة، كما أن زكاة الأموال الباطنة

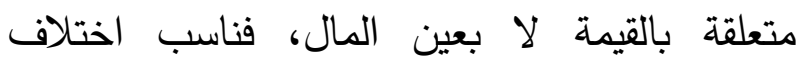
الحكم، وهو قول جمهور أهل العلم قال ابن قدامة

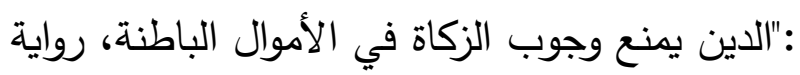
واحدة، وهي: الأثمان، وعروض التجارة، وبه قال

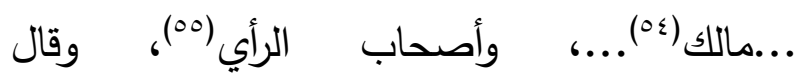

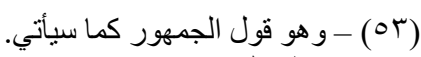

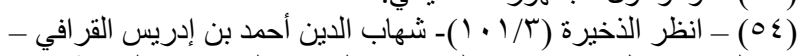

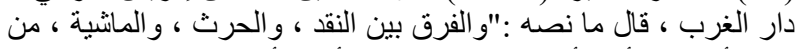

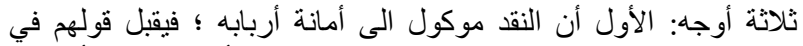

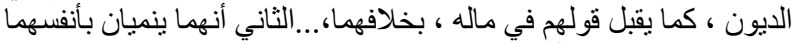

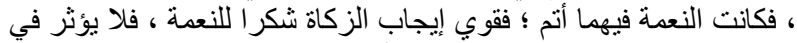

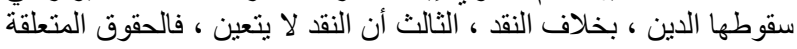

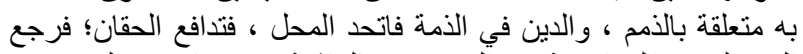

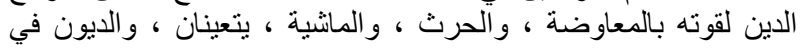

هذا أهم ما يتعلق بركن الزكاة الثاني، وما يشترط له،

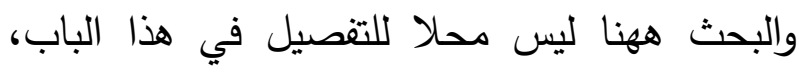
وحسبنا الإشارة بأهم ما تتبغي الإشارة إليه. الفرع الثالث: شروط المال المزكى. ليس الحديث ههنا عن الأموال التي تجب فيها

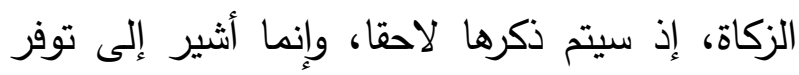
الشروط التي بها تجب في المال لبذل الزكاة وهي:

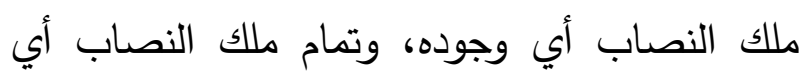
استقرار ملكيته، ومضي الحول في غير الحبوب وجي ولهاب والثمار، والمعدن ؛ لأن الزكاة فيها متعلقة بوقت فئت

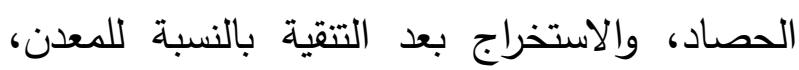

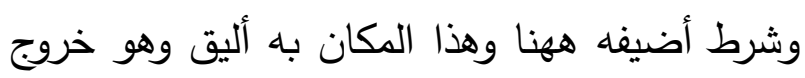
المال عن دورته الاقتصادية بالإرادة( (0).

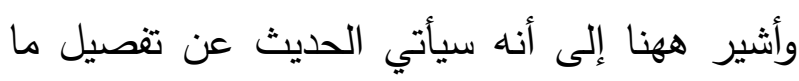
يتصل بالنصاب، والحول لاى الحديث عن الأموال

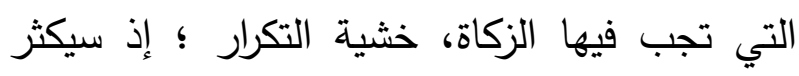
ذكر متعلقات بهذه الشروط لدى الحديث عنها.

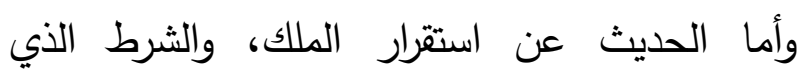
أضفته ؛ وهو خروج المال عن دورته الاقتصادية بالإرادة، فسأتحدث عنهما في مسألتين: المسألة الأولى: استقرار الملك.

ويعبر عنه بعض الفقهاء بقولهم: تمام الملك، وهو عبارة عما كان بيده ولم يتعلق به حق لغيره، فيمكنه أن يتصرف فيه على حسب اختياره، وفوائده حاصلة لئل (O)

(0) - (0) - سياتي شرح ذلك.

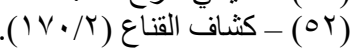


دين لله عليه ؛ فإنه غني يملك نصابا، يحقق هذا أن الزكاة إنما وجبت مواساة للفقراء وشكرا لنعمة الغنى، والمدين محتاج إلى قضاء دينه كحاجة الفقير، أو أشد، وليس من الحكمة تعطيل حاجة المالك لحاجة غيره، ولا حصل لله من الغنى ما يقتضي الشكر بالإخراج، وقد قال النبي ثي :" أبدأ بنفك ثم بمن تعول"(·7)، فصل: فأما الأموال الظاهرة، وهي: السائمة، والحبوب، والثمار ، فروي عن أحمد: أن الدين يمنع الزكاة أيضا فيها؛ لما ذكرناه في الأموال الباطنة، قال أحمد في رواية إسحاق بن إبراهيم: يبتدئ بالدين فيقضيه، ثم ينظر ما بقي عنده بعد

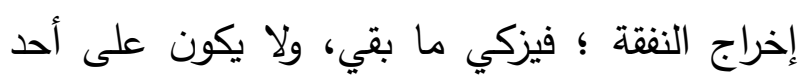
دينه أكثر من ماله صدقة، في إبل أو بقر أو غنم أو زرع، ولا زكاة، ...وروي أنه لا يمنع الزكاة فيها، وهو

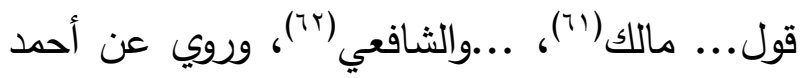
أنه قال: قد اختلف ابن عمر، وابن عباس، فقال ابن عرر: يخرج ما استدان، أو أنفق على ثرته وأهله، ويزكي ما بقي، وقال الآخر : يخرج ما استدان على

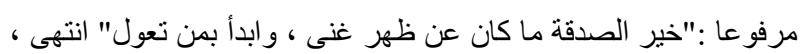

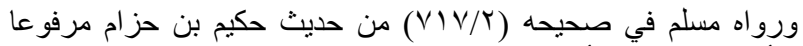

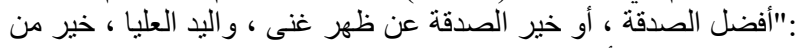

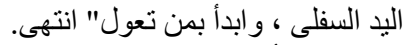

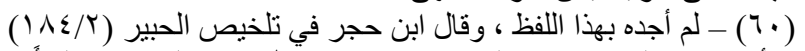

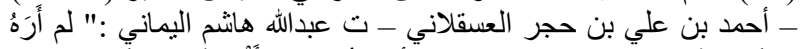

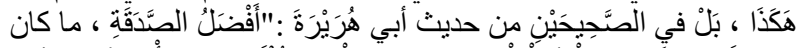

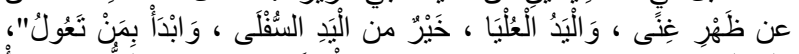

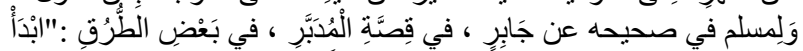

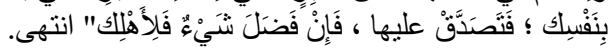

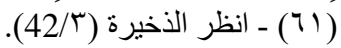

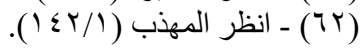

...الشافعي في جديد قوليه لا يمنع الزكاة(04....ولنا ما روى أبو عبيد في الأموال...عن السائب بن يزيد قال سمعت عثمان بن عفان يقول :"هذا شهر زكاتكم ؛ فمن كان عليه دين فليؤده ؛ حتى تخرجوا زكاة

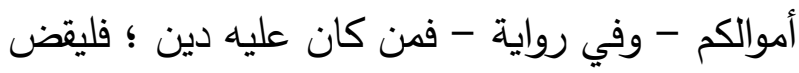

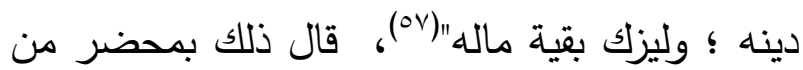
الصحابة فلم ينكروه ؛ فدل على اتفاقهم عليه ...ولأن

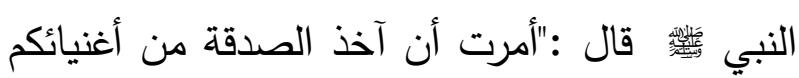

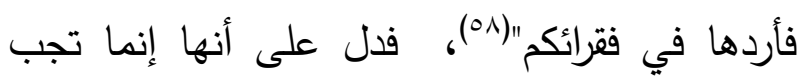

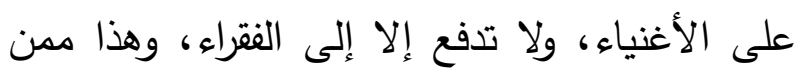

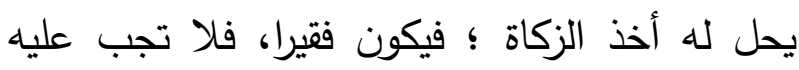
الزكاة، لأنها لا تجب إلا على الأغنياء للخبر ، ولقوله

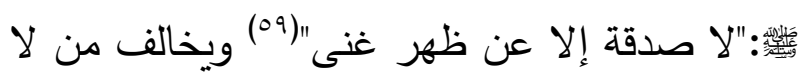

الذمم ؛ فلا منافاة ، وأما المعدن فأنثبهه بالحرث" انتهى وهو كلام نفيس تجدر ملاحظته.

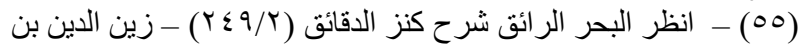

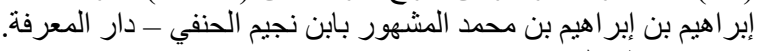

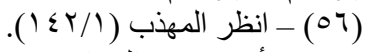

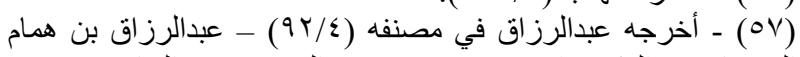

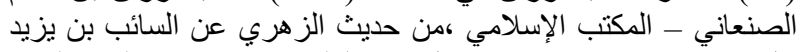

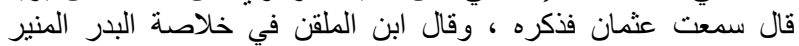

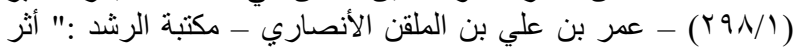

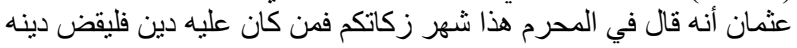

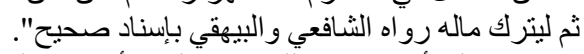

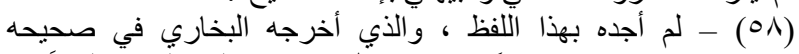

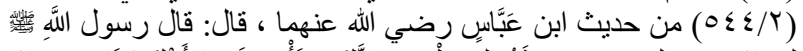

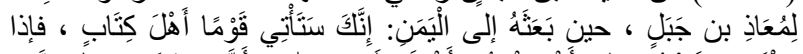

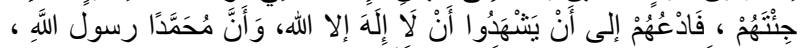

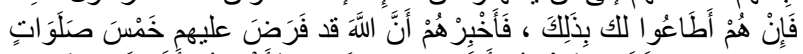

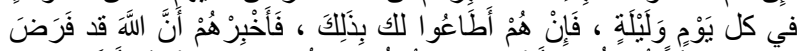

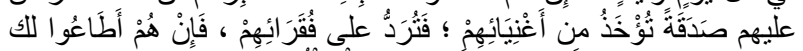

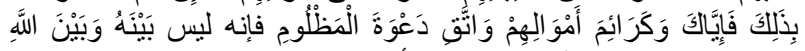

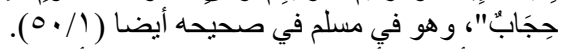

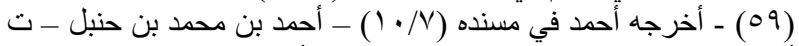

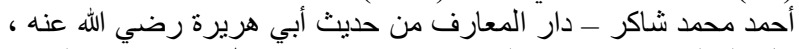

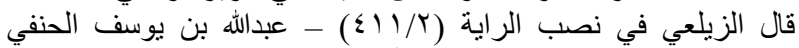

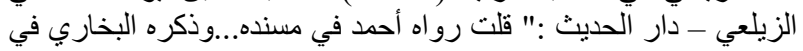

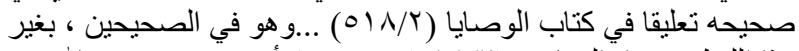

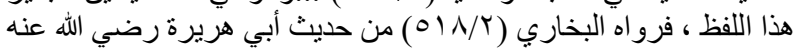




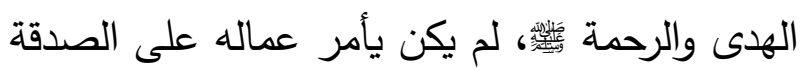
بأخذ زكاة الأموال الباطنة، ولم يكن يأمرهم بالسؤال عن الديون التي على أصحاب الأموال الظاهرة، فل هذا أنها تؤخذ منهم على كل حال، لأن حقوق الناس أولى من توفير أموالهح الظاهرة، فايجاب الزكاة فيها يحفزهم لسداد ما للناس ؛ ببيع شيء من تلك الأموال، ولبيعها حالتئذ أثر بالغ في تقليل

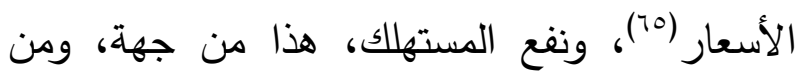
جهة ثانية فإن للأموال الظاهرة وظيفة، وتتعلق بها حاجات الناس أكثر مما تتعلق بالأموال الباطنة، فأخذ الزكاة منها إدخال لها في الدورة الاقتصادية المتعلقة بالأموال الظاهرة، واستنزال الزكاة بالدين الباطن توفير في المال الظاهر ، وإخراج لله عن تلك الدورة بشيء غير ظاهر وهذا غير سائغ عقلا"(rا). ما سبق مختصر يتعلق بالحقوق التي للعباد، من جهة منعها وجوب الزكاة في قدرها، فهل هذا التأثير يصح بشأن الحقوق المالية التي تجب حقا لله تعالى، كالكفارات، والنذور، ودين الحج ونحوها ؛ الجواب: لا، على التحقيق ؛ إذ تجب الزكاة ولا أثر لهذه ودئ

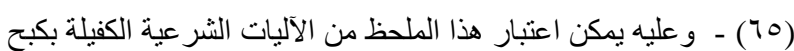

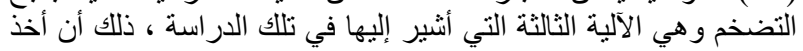

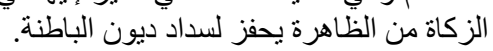

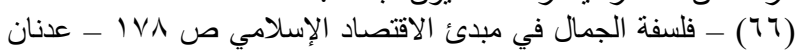

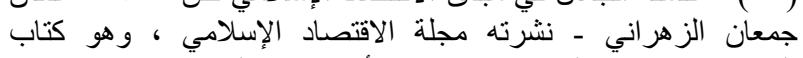

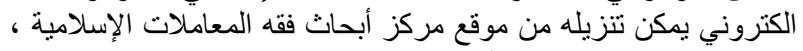
ومن موقع مكتبة نور انظر الرنابل من مونع https://www.noor-book.com/\%D9\%83\%D8\%AA\%D8\%A7\%D8\%A8\%D9\%81\%D9\%84\%D8\%B3\%D9\%81\%D9\%87\%D8\%A7\%D9\%84\%D8\%AC\%D9\%85\%D8\%A7\%D9\%84-\%D9\%81\%D9\%8A\%D9\%85\%D8\%A8\%D8\%A7\%D8\%AF\%D8\%A6\%D8\%A7\%D9\%84\%D8\%A7\%D9\%82\%D8\%AA\%D8\%B5\%D8\%A7\%D8\%AF\%D8\%A7\%D9\%84\%D8\%A7\%D8\%B3\%D9\%84\%D8\%A7\%D9\%85\%D9\%8A\%D8\%AA\%D8\%AD\%D9\%84\%D9\%8A\%D9\%84\%D9\%88\%D8\%AA\%D8\%B7\%D8\%A8\%D9\%8A\%D9\%82\%D8\%A7\%D8\%AA\%D9\%81\%D9\%82\%D9\%87\%D9\%8A\%D9\%87-pdf
ثرته ويزكي ما بقي، وإليه أذهب أن لا يزكي ما أنفق على ثرته خاصةة"(rآ) انتهى. والصحيح في المسألة ما ذكرته في القاعدة أعلاه، والبحث ههنا طويل التوابع، ويخرج استقصاؤه عن غاية الدراسة، وأكتفي ههنا بذكر الجمل الكلية، وعليه أذكر ما قررته في هذا الشأن ضمن دراسة أشرت إليها سابقا ؛ قلت :"الملحظ الجمالي هنا أنه

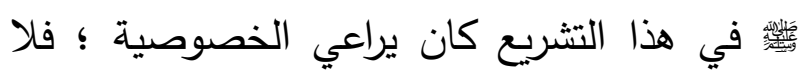
تتتهك، بحيث يكثف ما ستر عن الناس، وهذا هو سبب التقريق بين الأموال الظاهرة والباطنة، فالظاهرة تؤخذ منها الزكاة لظهور أمرها، ولا يوجد تكلف لمعرفتها، ولا تفتيش عنها، ولا انتهاك لخصوصية صاحبها، وعليه لو توفر ذلك لغير تلك الأموال لاستوى الحكم، وههنا ملحظ جمالي آخر؛ إذ نجد الشرع المطهر يخرج من وعاء الزكاة الديون التي

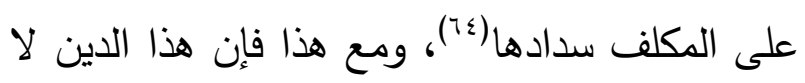
يؤثر على الوعاء الزكوي في الأموال الظاهرة ؛ فهي تزكى إذا توفرت شروط زكاتها في ذاتها بصرف النظر عن الدين الذي على المكلف ؛ لأن رسول

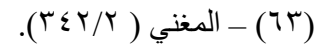

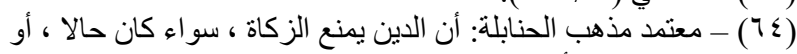

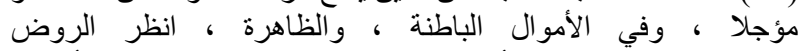

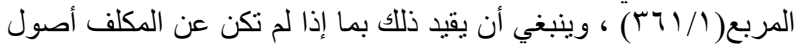

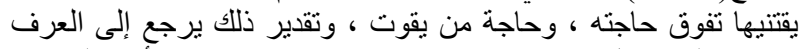

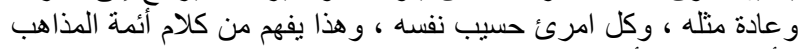

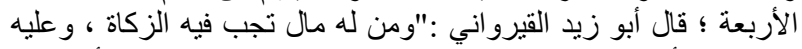

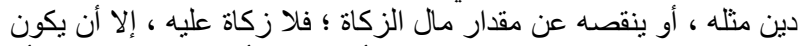

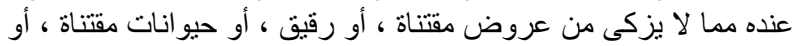

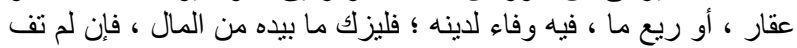

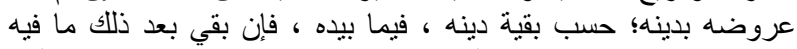

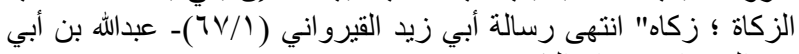
زيد القيرواني - دار الفكر. 
للعباد حالا كان أو مؤجلا، أو كان مهر زوجة أو

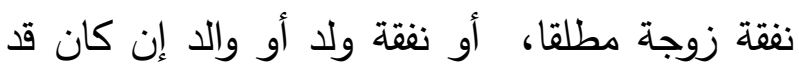

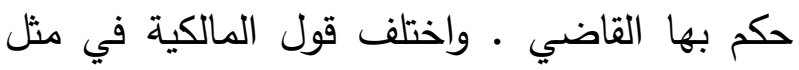
دين الكفارة والهدي الواجب فاختار منها خليل وابن

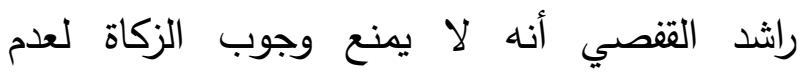

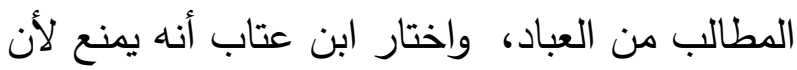

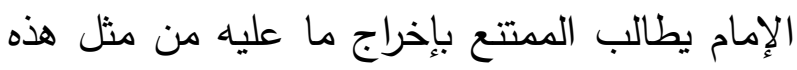

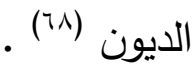
وأما الحنابلة فيرون أن حقوق الله المالية تمنع وجوب الزكاة في قدرها ؛ كما هو حال ديون الآدميين (79). المسألة الثانية: خروج المال عن دورته الاقتصادية

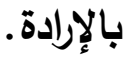
إن اشتراط البلوغ، والعقل، لوجوب الزكاة شيء اختلف فيه علماؤنا الكرام ؛ فمن قائل به، ومن قائل بخلافه، ويبدو لي أن إطلاق الشرط على هذا النحو؛

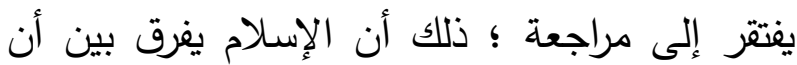
يكون المال قد خرج من دائرة النفع الاقتصادي بإرادة المكلف، وما ليس كذلك، لأن حكمة التشريع ظاهرة في أن القصد من فرض الزكاة؛ هو إيجاد حافز يحمل المرو على إعادة المال ليخخل في دورته

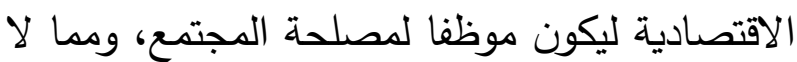
ريب فيه أن القصد منتف لاى الصبي، ولدى غير موطيه العاقل ؛ ما يقتضي اختلاف الحكم، وهذا الملحظ

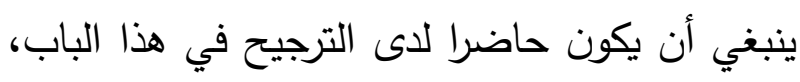

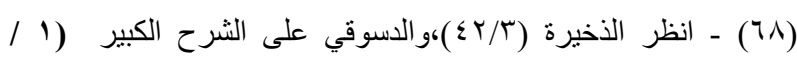

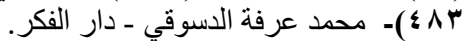

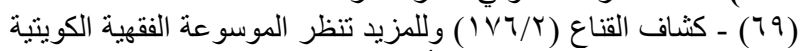

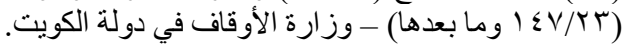

الديون في منع قدرها من تعلق الوجوب به، لأن

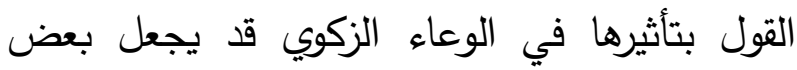

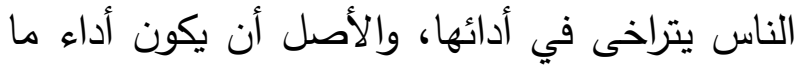

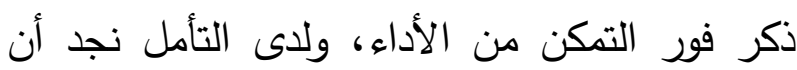
أداءها بمجرد التمكن سيعني نقصا بقدرها، ما يخرج هذا القدر من تعلق الزكاة به، فهرنا ظفرنا بأمرين،

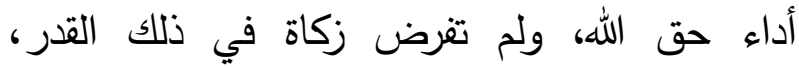
صحيح قد يقال: إن الزكاة لا تتعدى ربع العشر، وأنت ههنا ذهبت بأضعاف ذلك، والرد إن أداء حقوق الله فور التمكن ؛ خير من البحث عن البر

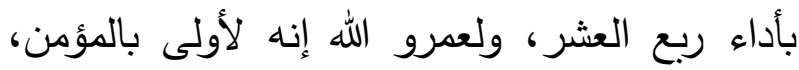
وأجدر، وما ذكرته آنفا تحقيق يلخص لك لك المسألة، وهو مذهب الثافعية، علما بأن الحنفية ذهبوا إلى أن الدين الذي يمنع وجوب الزكاة هو ما كان له مطالب

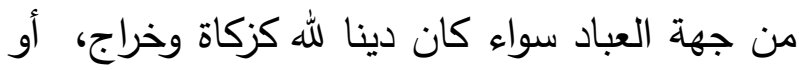

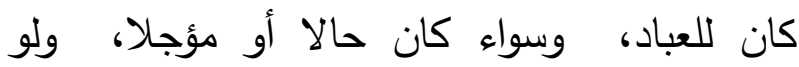

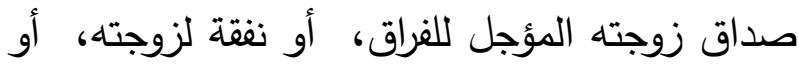
لقريب لزمته بقضاء أو تراض، وكذا عندهم دين الكفالة، قالوا : لأن الكفيل محتاج إلى ما بيدهاه

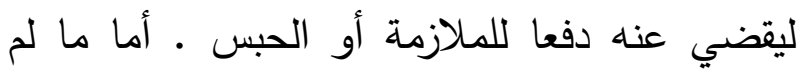

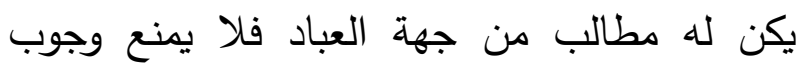
الزكاة، قالوا : كدين النذر والكفارة والحج، و ومثلها الأضحية، وهدي المتعة، ودين صدقة الفطر (TVآن. وذهب المالكية إلى أن زكاة المال الباطن، يسقطها الدين ولو كان دين زكاة، أو زكاة فطر، أو كان إن ليطن 
من الأرض ففيها الزكاة، وذلك لأنهم ليسوا من أهل

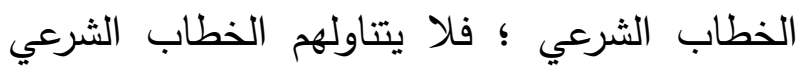
بأي فريضة إسلامية كالصلاة ونحوها، وإلحاق المغیى عليه بالمجنون أولى من إلحاقه بالنائُ؛ كونه لا يدري عن حالته بعد الإفاقة إن لم يخبر بإغمائه،

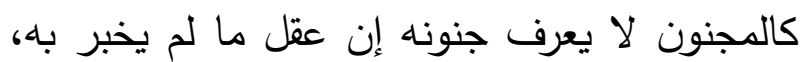

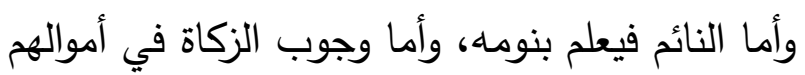

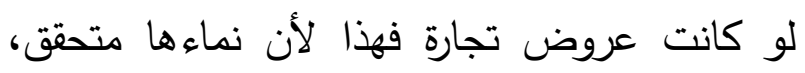

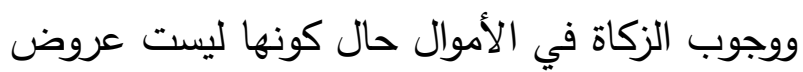
تجارة ذلك لأنها موضوعة للنماء معنى؛ فلما أخرجها

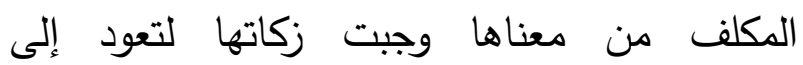
موضوعها، وقد اعتبر فيها النماء حكما، وسماه الفقهاء حالتئذ بالنماء الحكمي ؛ لهذا السبب، وإنما لم تجب الزكاة في أموال من تم ذكرهم أعلاه حين تكون لهم أموال ليست عروض تجارة ؛ ذلك لأنه لم يقم

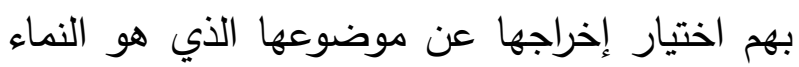
الحقيقي باستثمارها والعمل فيها، فلم يتعلق بها ما ما لهاء

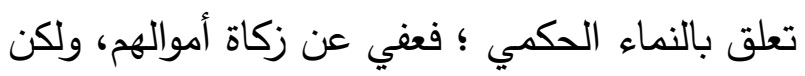
لو تم استثمار أموالهم من خلاه من له الولاية على بلى لهن

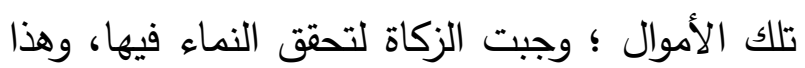
الاعتبار أولى بتحقيق الراجح في هذه المسألة؛ لأنها

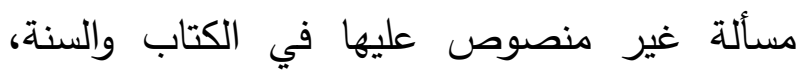
والمفزع فيها إلى الاعتبار الشرعي، وإنما وجبت الزكاة في الأموال بصفة عامة كي تبقى تلك الأموال داخلة في دائرة العمل الاقتصادي، وتؤدي دورها في لاهي

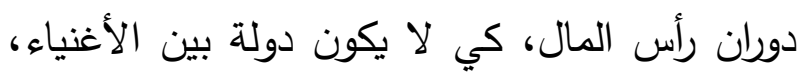

وهو محل اعتبار علمائنا بجميع مذاهبهم(•)، غير أن الرؤى تختلف، وهذه سنة لا تتكر، وهي طبيعة

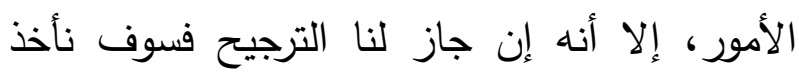
منحى يراعي ما نؤمن به من غايات من أجلها

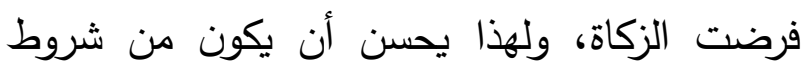
الزكاة ربطها بقصد المكلف لا بالمال، بحيث يكون

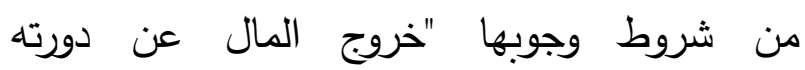
الاقتصادية بالإرادة"؛ فمتى خرج المال عن عن دورته الاقتصادية بإرادة من المكلف؛ وجبت فيه الزكاة، ومتى خرج لا عن إرادة لم تتعلق به زكاة، ليكون هذا لـان

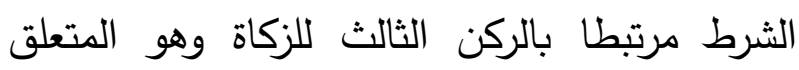

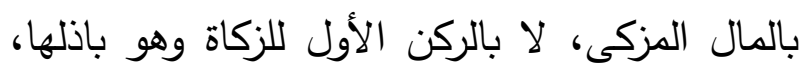
وهذا ملحظ جمالي يعبر عن جمال الشريعة وكمالها، لإلهال مع حفظ التوقير لسائر كلام علمائنا، غير أن أن الموطن موطن بحث وسيبقى، ومن الله نستمد العون

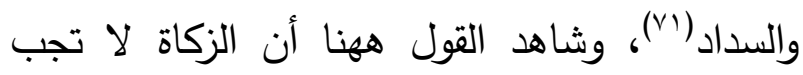

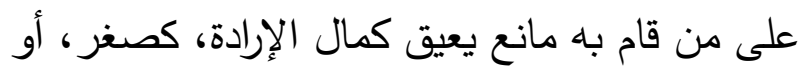
جنون، أو عته، أو إغماء، والعبرة في ذلك بلك بلحظة الإنة

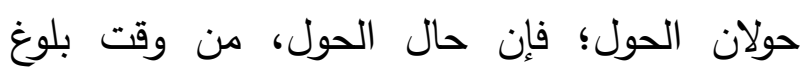
النصاب، والمانع موجود لم تجب، إلان أن تكون أموالهم عروض تجارة، وكذا حين تكون من الخارج

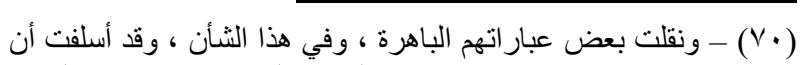

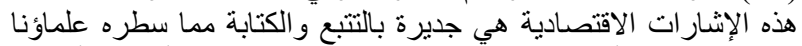

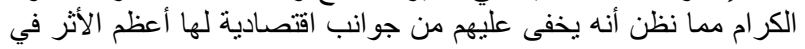

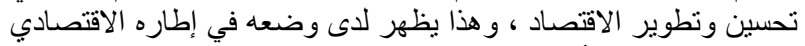

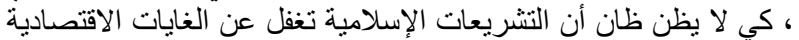

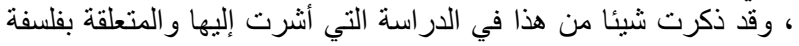
الاقتصاد الإسلامي.

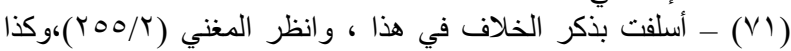

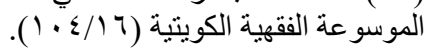


عموم الخطاب في الزكاة مسوغا لإيجابها على غير المكلفين ؛ لكان العموم في غيرها كذلك، وإنه باطل التهاه بالإجماع، وما استلزم الباطل ؛ باطل" "(Vr).

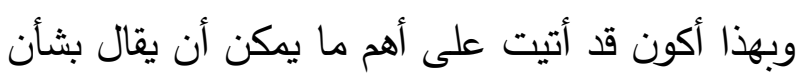

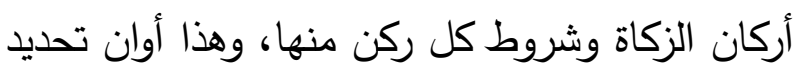
الأموال التي تجب فيها الزكاة، وهو المبحث الثالث. المبحث الثالث: الأموال التي تحب فيها.

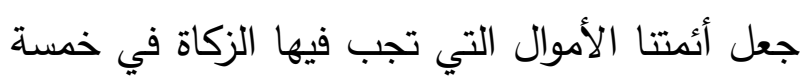
أموال هي:

السائمة من بهيمة الأنعام، والأثمان، وعروض المان

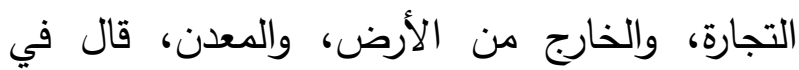

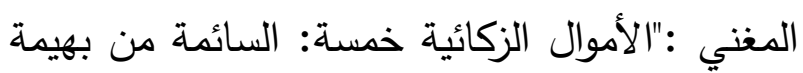
الأنعام، والأثمان وهي: الذهب الذان والفضة، وقيه عروض التجارة، وهذه الثلاثة الحول شرط في وجوب التهاب

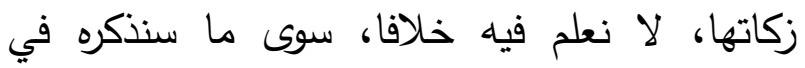
المستفاد، والرابع: ما يكال، ويدخر من الزروع والثمار، والخامس: المعدن ؛ وهذان لا يعتبر لهما لهان

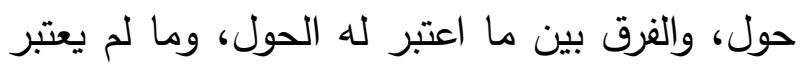

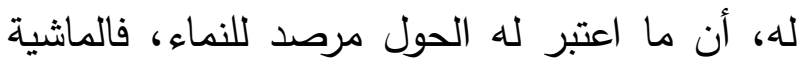

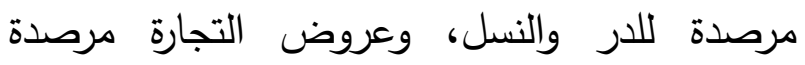

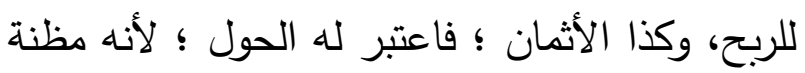

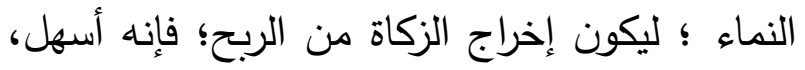

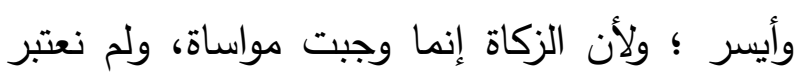

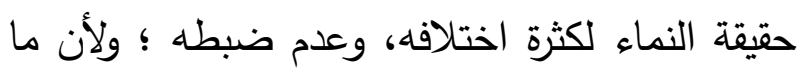
اعتبرت مظنته ؛ لم يلتنت إلى حقيقته، كالحكم مع وعنه
فلما خرجت أموال من تم ذكرهم عن تلك الدورة بغير إرادة منهم، لم يعاملوا معاملة من أخرجها بإرادة منه،

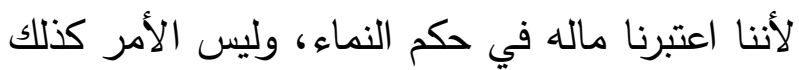
في حقهم، ولكن لو تم استثمارها سقط هذا الاعتبار

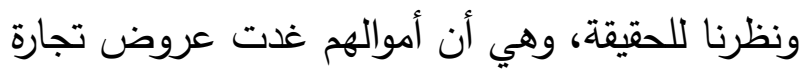
؛ فوجبت فيها زكاة عروض التجارة، وكذا القول في زكاة الخارج من الأرض؛ لأنه نام حقيقة؛ هذا التقرير

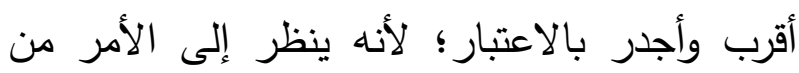

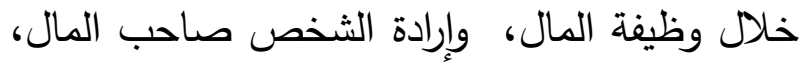
وليس من خلال حالة المكلف دون النظر في اعتبارات أخرى؛ قال الشوكاني في الدراري المضيئة :"إيجاب الزكاة عليه [أي على الصغير باعتباره مثالا لقيام مانع مما ذكر]إن كان بدليل ؛ فما هو؟ فما جاء عن الشارع في هذا شيء مما تقوم به الحجة، كما يروى عن النبي صلى الله عليه وسلم: أنه أمر فئ لهاء بالاتجار في أموال اليتامى؛ لئلا تأكلها الزكاة (Yr) فلم يصح في ذلك شيء مرفوعا إلى النبي صلى الله عليه وسلم، وأما ما روي عن بعض الصحابة ؛ فلا حجة فيه، وقد عورض بمثله...، وإن قال قائل: إن

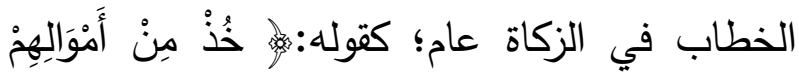

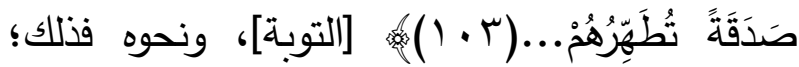
ممنوع، وليس الخطاب في ذلك إلا مع من يصلح له

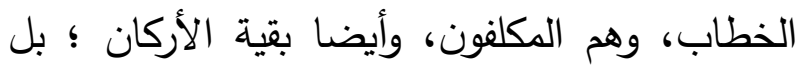
وسائر التكاليف التي وقع الاتفاق على عدم وجوبها على من ليس بمكلف، الخطابات بها عامة، فلو كان 
ويبقى أن أشير إلى أن ما يستفاد خلال الحول، مما وجبت فيه الزكاة الحولية فهو لا يخلو من ثلاثة إنة أقسام:

الأول: أن يكون المستفاد من نمائه، كربح مال

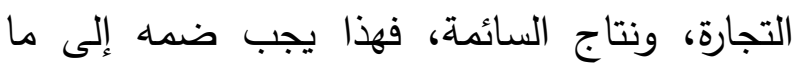
عنده من أصله فيعتبر حولا بحوله، قال في المغني "لا نعلم فيه خلافا؛ لأنه تبع له من جنسها، فأشباه

النماء المتصل، وزيادة قيمة عروض التجارة"(نَ). الثاني: أن يكون المستفاد من غير جنس ما عنده ؛

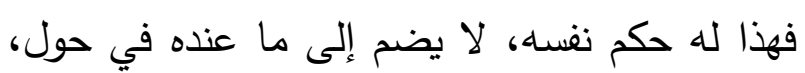
ولا نصاب، فإن بلغ نصابا استقبل به حولا، وزكاه بعد مضي الحول، وإلا فلا شيء فيه ؛ قال في

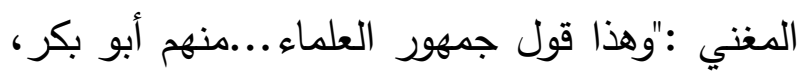

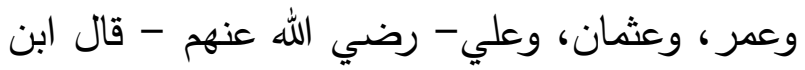
عبد البر على هذا جمهور العماء، والخلاف في ذلك شذوذ ولم يعرج عليه أحد من العلماء ولا قال به هوله

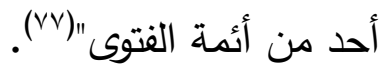
الثالث: أن تجب الزكاة في مال لديه، وقبل أن ينقضي الحول يستفيد مالا من جنسه لا بسبب ذلك

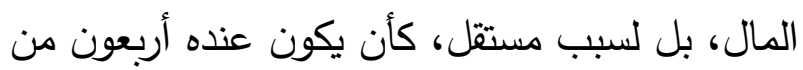
الغنم، مضى عليها بعض الحول، فيوهب مائة، فهذا لا تجب فيه الزكاة، حتى يمضي عليه حول أيضا،

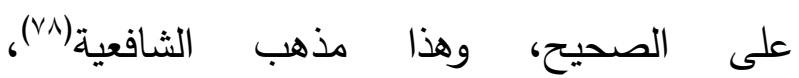
والحنابلة(19)، وقال أبو حنيفة(·) يضمه إلى ما عنده
الأسباب ؛ ولأن الزكاة تتكرر في هذه الأموال ؛ فلا بد لها من ضابط ؛ كيلا يفضي إلى تعاقب الوجوب

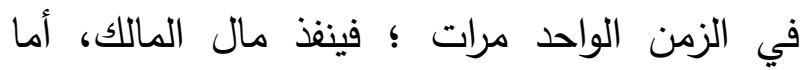

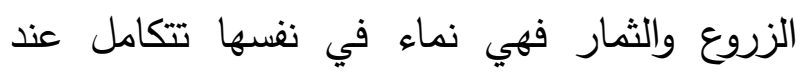
إخراج الزكاة منها ؛ فتوخذ الزكاة منها حينئذ، ثماه تعود في النقص لا في النماء، فلا تجب فيها زكاة ثانية ؛ لعدم إرصادها للنماء، والخارج من المعدن

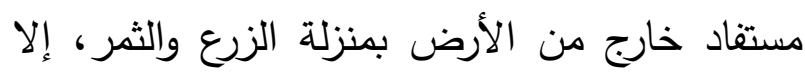

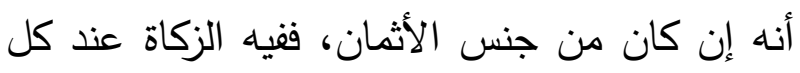

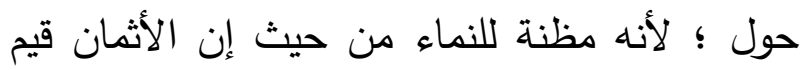

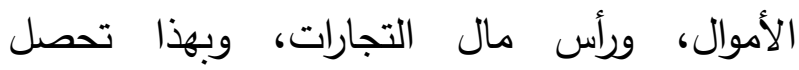
المضاربة، والثركة، وهي مخلوقة لذلك فكانت

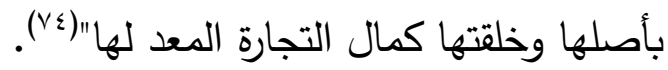
الجملة آنفا تضع أيدينا على جانب نفتقر للتركيز

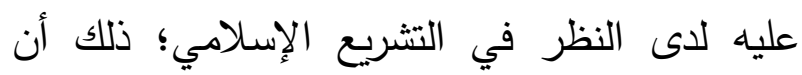

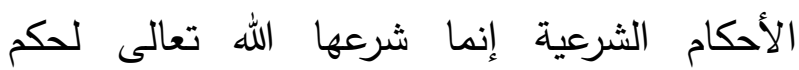
وأسباب، وليست تشريعات تعبدية فقط؛ لاسيما بشأن

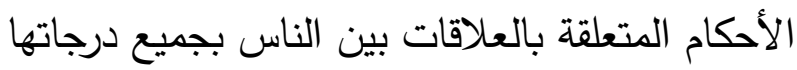

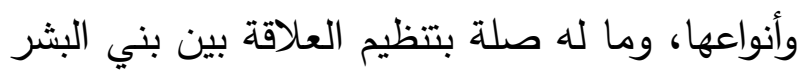
؛ فشريعتا ليست صماء بل هي كاملة الحواس لهاس وأحكامها لا تخلو عن معنى معقول، علمه من علمه

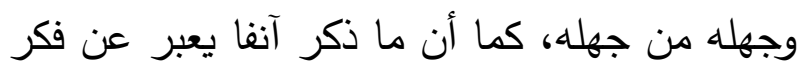
اقتصادي راسخ (vo).

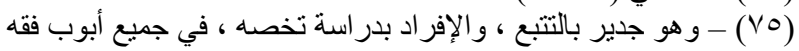

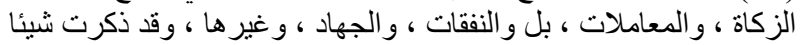

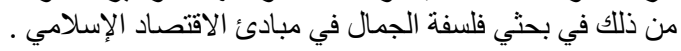


على الحول، ولأنه مملوك أصلا، فيعتبر فيه الحول شرطا، كالمستفاد من غير الجنس، ولا تشبه هذه الأموال الزروع والثمار؛ لأنها تتكامل ثمارها دفعة واحدة، ولهذا لا تتكرر الزكاة فيها، وهذه نماؤها

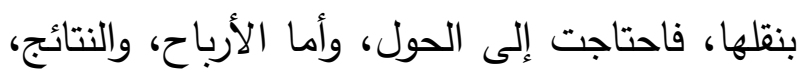

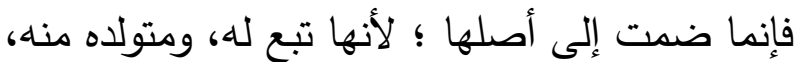

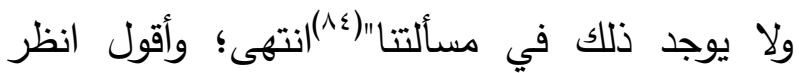
كيف تم الربط بين الحكم، والحكمة، والسبب، وكيف تم التفريق بين أنواع المال، وما يزكى بالحول وما لتربن

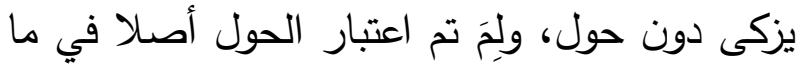

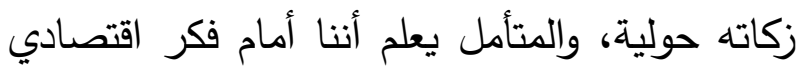
أصيل، وليس أمام تشريع فقهي فقط. وبعد معرفة الأموال التي تجب فيهام الزكاة، والتوقيت فئيت

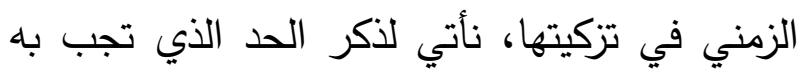
الزكاة من تلك الأموال، وهو ما سماه علماؤنا

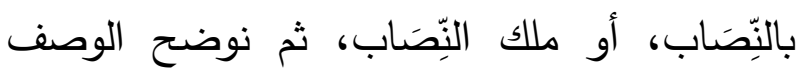
المتعلق بهذا الملك، وهو استقراره. الأموال الزكوية هي: السائمة من بهيمة الأنعام،

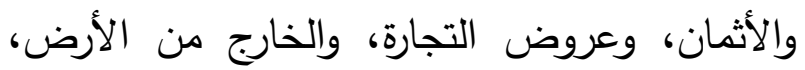

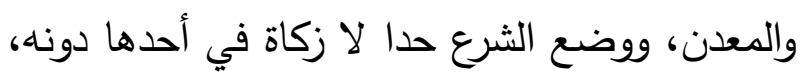
وإذا زاد عن الحد وجبت؛ ولهذا نجد بعض علمائنا اعتبر ذلك الحد فرقا بين الغني، وغير الغني(د0)،

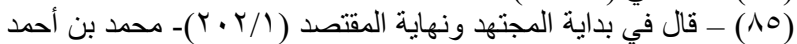

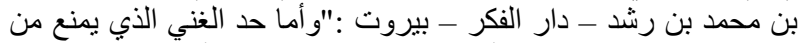

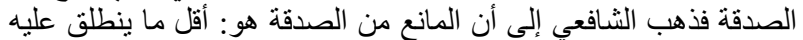

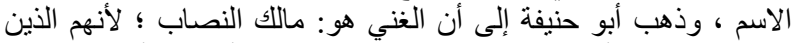

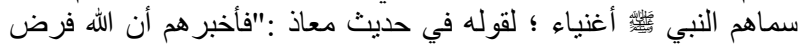

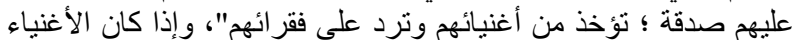

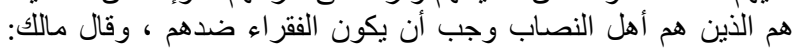

في الحول ؛ فيزكيهما جميعا عند تمام حول المال

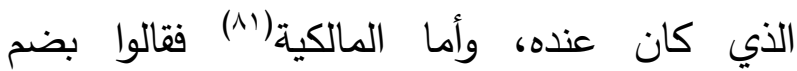
المستفاد من جنس المال، ولو لم يتولد عنه، لحول المال الذي عنده، ويزكيهما معا في السائمة، دفعا للتشقيص(Ar) الواجب، وهم في هذا كالحنفية، وقالوا كقول الثافعة والحنابلة، في الأثمان لعدم ذلك فيها. وليس هذا البحث مخصصا لذكر مسائل الزكاة على لهى لهـ نحو مفصل، وذكر الأدلة مع الترجيح، في غير ما لهابل نحن بصدد الحديث عنه، فهذا له موطن به أليق، ولكي لا يذهب بنا السياق عن غاية البحث، وللتركيز أكتفي بذكر كلام ابن قدامة في بيان الراجح

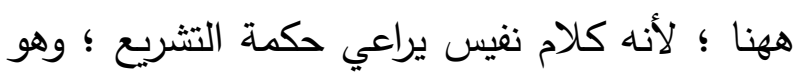

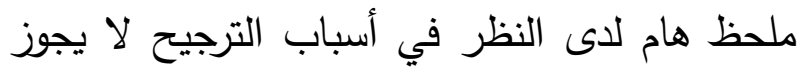

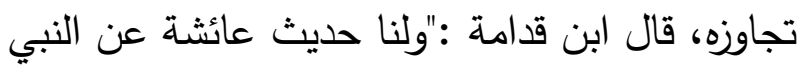

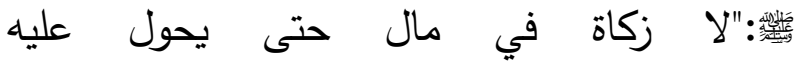

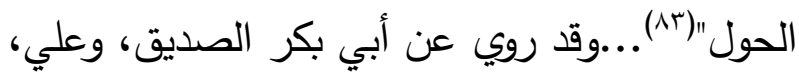
وابن عمر، وعائشة، وعطاء، وعمر بن عبد العزيز،

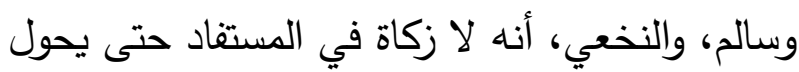

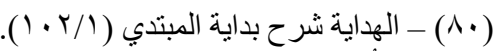

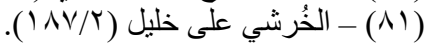

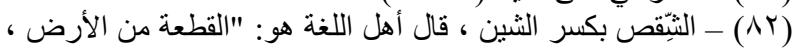

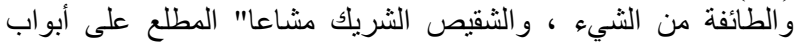

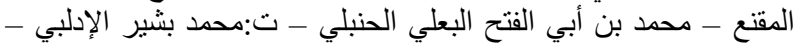

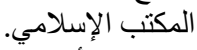

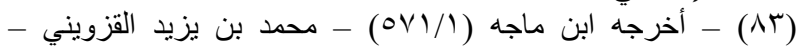

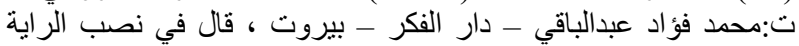

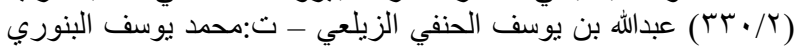

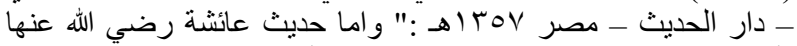

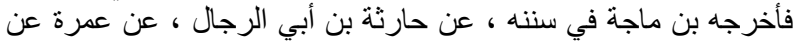

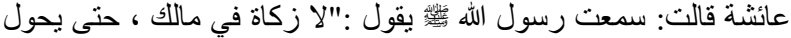

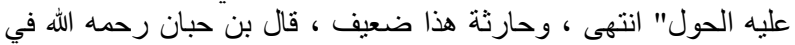

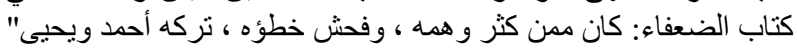


والنكتة التي تحسم النزاع بشأن اشتراط وصف السوم

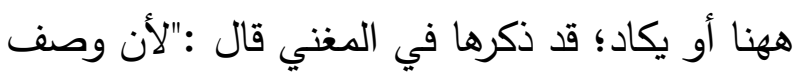
النماء معتبر في الزكاة، والمعلوفة يستغرق علفها

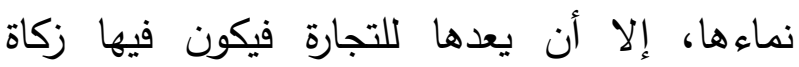
التجارة"(•)(انتهى، وقد ذكرت في بحث سابق تفدهاء يوضح هذا، فقلت:" وهذا يعني أنه لا تجب ولب الزكاة فيها إذا كانت لدر، ونسل، أو عاملة؛ لأن السوم يرفع المؤونة عن صاحبها، فلا يتكلف لنمائها؛

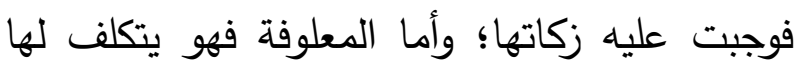
مؤونة كبيرة للحفاظ على حياتها واستمرار درها ونسلها، ولوجودها على هذا النحو نفع للسوق المرتبط بتأمين علفها، فهي تؤدي دورها فودا في نفع

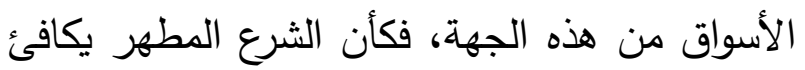
مالكها لدوره في تحريك السوق المرتبط بتأمين احتياجات تلكم الأنعام، كما يكافئه على إحسانه لهذه العجماوات، ليبدو الأمر كما لو أنه بذل الزئل الزكاة لإطعامها فلا ثنيا عليه فيها. وقاعدة الزكاة الأولى هي: أن ما يحتاجه الإنسان

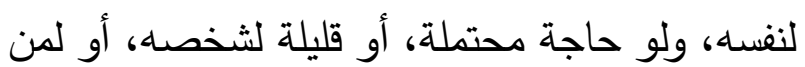

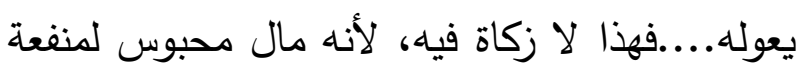
صاحبه، فهو مال دائر في فلك صاحبه، ويحقق لاهن دوره في الاقتصاد الكلي، لأن وجود هذا المال بيد الثخص؛ يجعل الشخص في جاهزية للعمل، وبذل لفيل النفع للمجتمع، فان زاد المال عن الحاجة الشخصية،

و إن كان قدر ال ايقى الحيوان دونه ؛ سقطت الزكاة ؛ لأنه لم يوجد تكامل

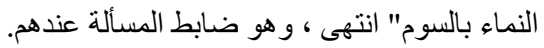

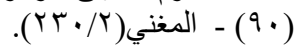

وسبق بيان شيء من هذا، وأما الأنصبة فلكل مال

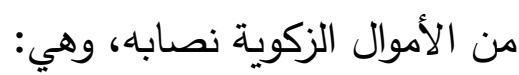

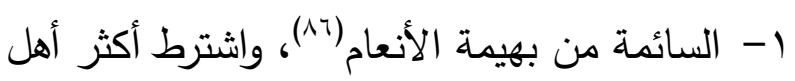
العلم لوجوب الزكاة في بهيمة الأنعام أن تكون بهن

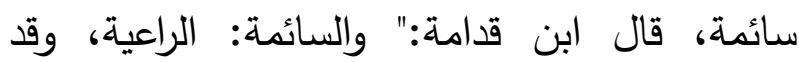
سامت، تسوم، سوما؛ إذا رعت، وأسمتها؛ إذا رعيتها، وسومتها ؛ إذا جعلتها سائمة، ومنه قول الله تعالى :

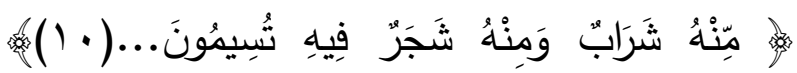

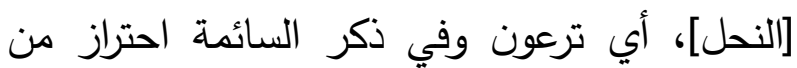

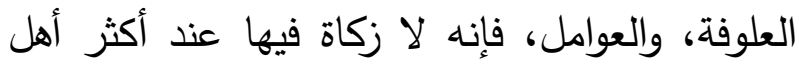

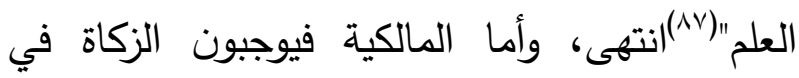

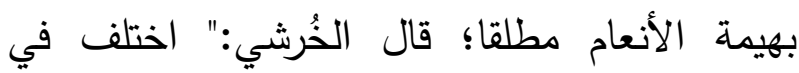
المعلوفة، في الحول أو بعضه، والعاملة في حرث أو الو

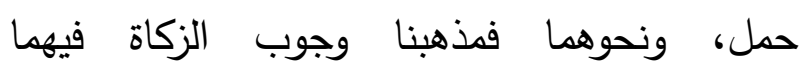

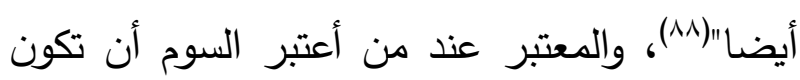
سائمة أكثر السنة، وهو قول الحنفية، والحنابلة، ولا زكاة فيها لو لم تكن سائمة عند الثافعية، ولا فرق

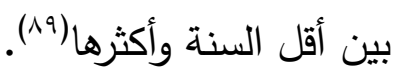

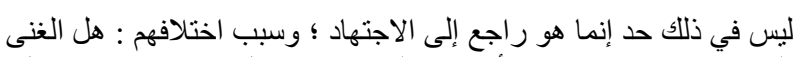

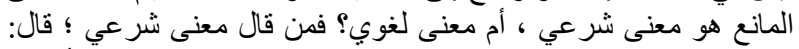

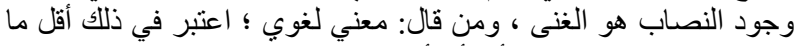

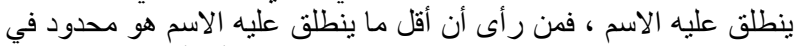

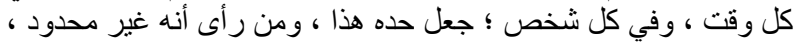

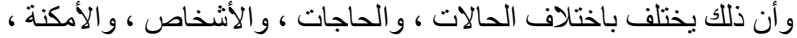
و الأزمنة ، وغير ذلك قال هو غير محدود وأن ذلك راجع إلى الاجتهاد والألئ

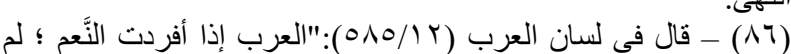

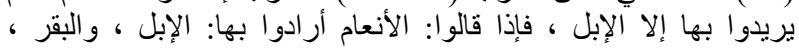

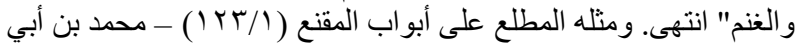

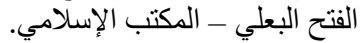

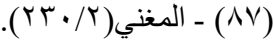

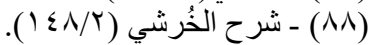

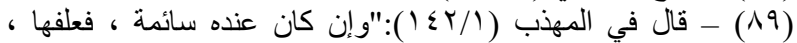

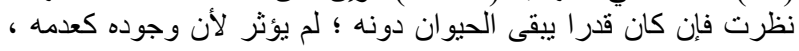


وأما النصاب في الإبل، فيبدأ بحساب حول زكاتها إذا بلغت خمسا، قال ابن قدامة :"أجمع المسلمون على أن ما دون خمس من الإبل لا زكاة فيه ؛ وقال

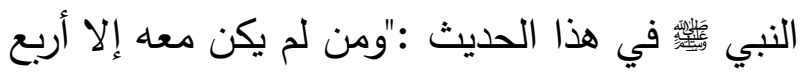
من الإبل ؛ فليس عليه فيها صدقة، إلا أن يشاء ربها"(90)، وقال :"ليس فيما دون خمس ذود صدقة" متفق عليه(ד9..... فإذا ملك خمسا من الإبل فأسامها أكثر السنة ؛ ففيها شاة، وفي العشر ؛ شاتان، وفي الخمس عشرة ؛ ثلاث شياه، وفي العشرين ؛ أربع شياه، وهذا كله مجمع عليه، وثابت بسنة رسول الله (9) وأكتفي بذكر ما سبق ؛ لأن البحث ليس مخصصا لذكر التفصيلات بشأن الزكاة، فهذا يخرج عن غاية البحث، ولهذا سأكتفي بمقدمات لا غنى عنها لبلوغ الغاية التي أنشدها من هذه الدراسة. وأما نصاب البقر، فيبدأ بحساب حول زكاتها متى بلغت ثلاثين، ولا زكاة في أقل من ذلك، قال ابن قدامة :"وليس فيما دون ثلاثين من البقر سائمة صدقة ؛ وجملة ذلك : أنه لا زكاة فيما دون الثلاثين من البقر في قول جمهور العلماء، وحكي عن سعيد بن المسيب، والزهري، أنهما قالا : في كل خمس شاة؛ لأنها عدلت بالإبل في الهدي والأضحية، فكذلك في الزكاة، ولنا ما تقدم من الخبر، ولأن نُصُبَ الزكاة إنما ثبتت بالنص، والتوقيف، وليس

(90) - أخرجه البخاري في صحيحه من حديث أبي بكر رضي الله عنه

(OTV/r)

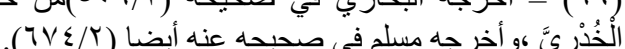

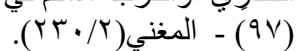

وحاجة من يعوله الشخص، ولو على سبيل الاحتمال، ولم ترتبط به نفقات تجعل له مؤونة يتحرك بسببها السوق، وفق التوصيف السابق؛ وجبت الزكاة فيه(19).

فالأموال إما أن تكون موضوعة للنماء أصلاه(بوج؛ كأموال التجارة، أو حكما كالنقود("ج)، وما لم يكن كذلك؛ فلا زكاة فيه، ولهذا لو جعل رب الأنعام، وهي غير سائمة من نيته التجارة فيها، غدت عروض تجارة وتزكى كعروض تجارة، لا زكاة

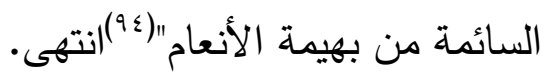

(9) - و ههنا وققة يسيرة ، أبدؤها بسؤال قد برد بناء على ما ذكر أعلاه

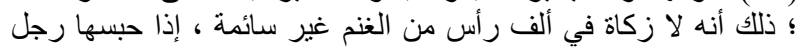

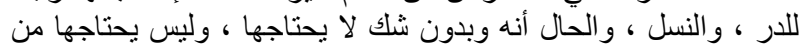

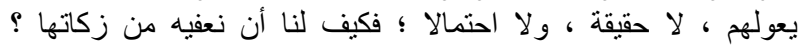

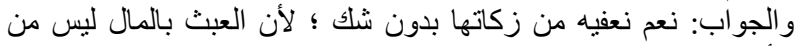

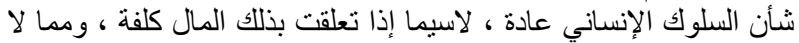

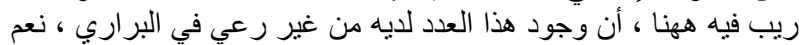

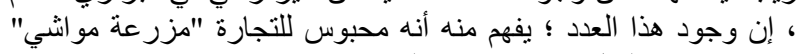

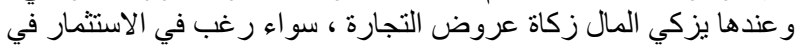

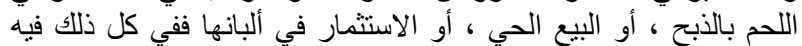

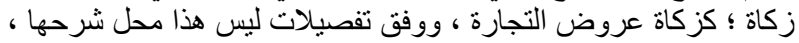

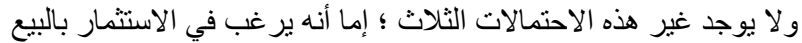

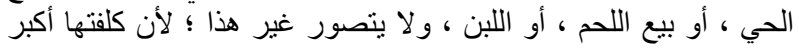

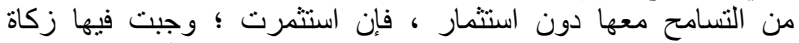

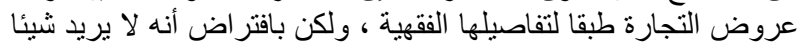

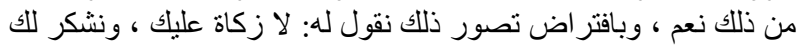

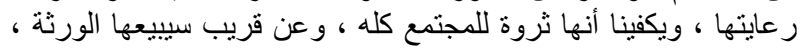

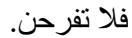
ملاحظة: ليس بصلح عند أهل الخبرة ، أن تبقى فحول كثر في هذا القطيع

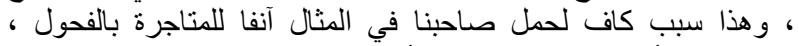

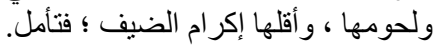

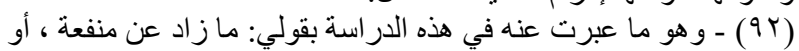

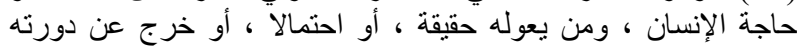

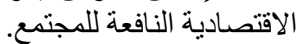

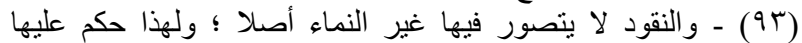

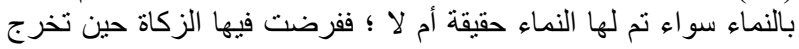
عن غايتها.

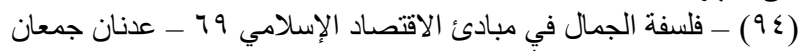
الزهر اني - نشر مركز أَّحاث فقه المعاملات الإسلاّمية - سامر قنطقي الإني 
وأما نصاب الذه، فيبدأ بحساب حول زكاته متى بلغ ما لديه عشرين مثقالا، وهي تساوي 10 غراما لمابا

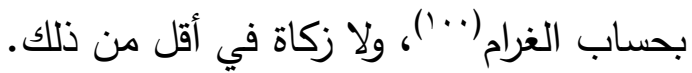

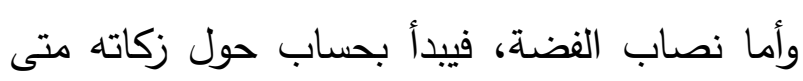
بلغ ما لدياه مائتي درهم، وهي تساوي

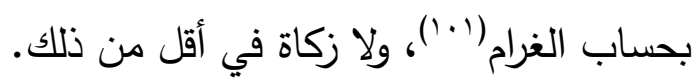

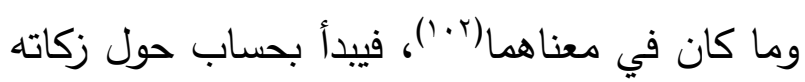
متى بلغ ما لديه قيمة مائتي درهم، ولا زكاة في أقل فئل فئل

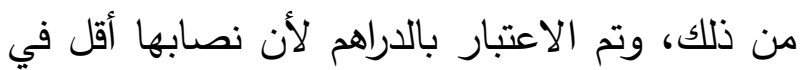

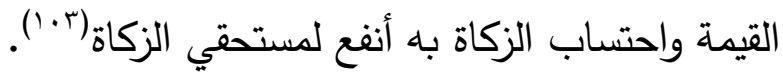

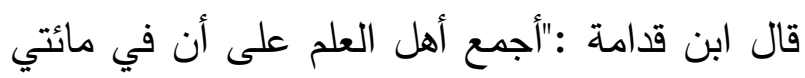

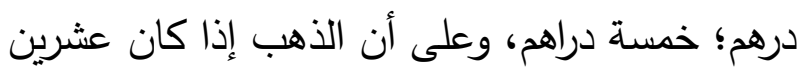

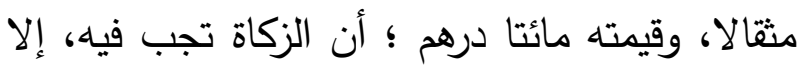

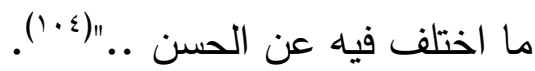

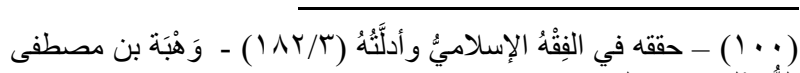

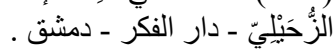

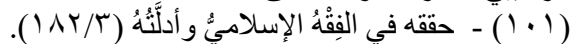

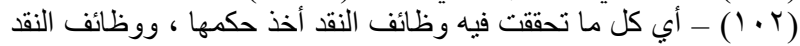

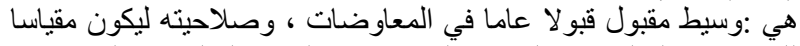

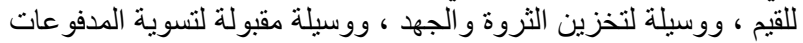

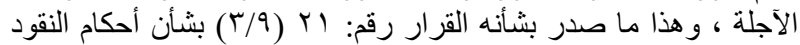

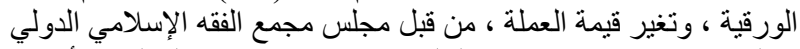

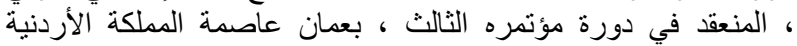

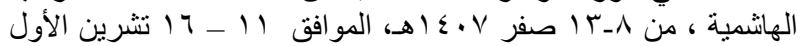

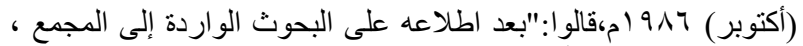

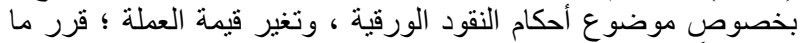

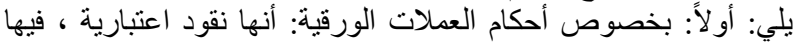

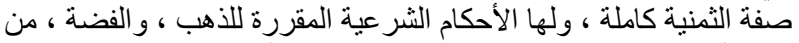

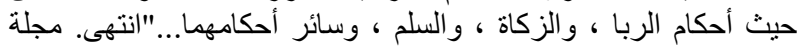

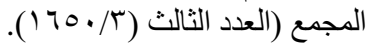

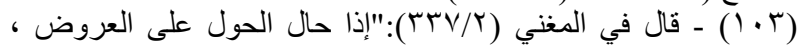

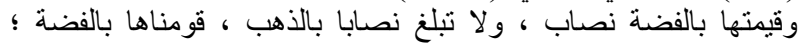

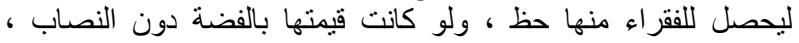

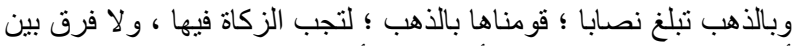

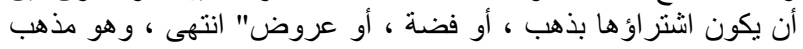

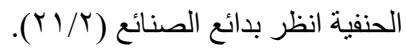

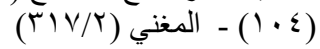

فيما ذكراه نص، ولا توقيف؛ فلا يثبت، وقياسهح

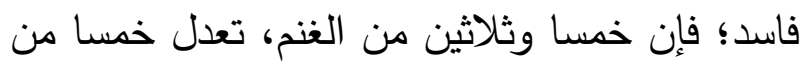

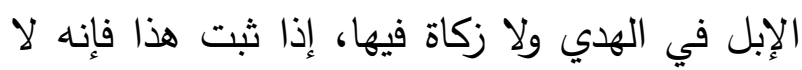
زكاة في غير السائمة من البقر في قول الجمهور

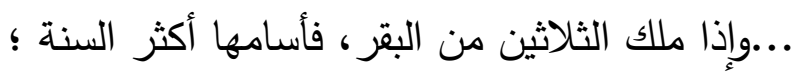

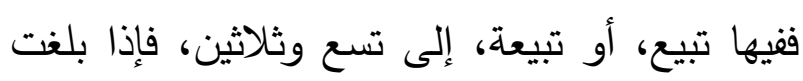

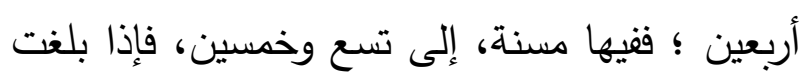

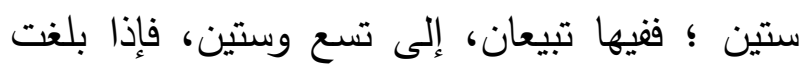

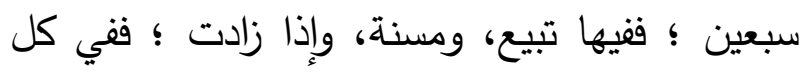

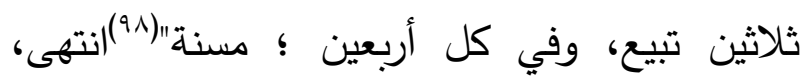

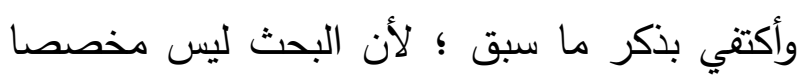

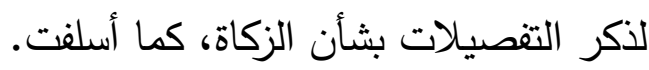

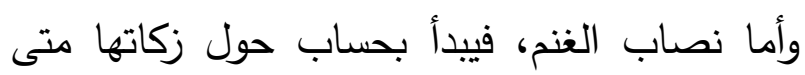
بلغت أربعين، ولا زكاة في أقل من ذلك، قال ابن ابن قدامة :"وليس فيما دون أربعين من الغنم سائمة

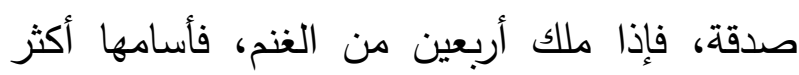
السنة؛ ففيها شاة إلى عشرين ومائة، فإذا زادت واحدة؛ ففيها شاتان، إلى مائتين، فإذا زادت واحدة ؛ فئئ ففيها ثلاث شياه، وهذا كله مجمع عليه"(99، وأكتفي واحتي

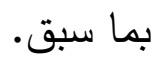

وأعود الآن للحديث عن نصاب باقي أنواع المال الذي فيه زكاة، وهو الحديث عن نصاب الأثمان. r- نصاب الأثمان: وهما الذهب (الدنانير) والفضة لأنة (الدراهم) وما كان في معناهما. 
بنقصه في أثنائه، وقال مالك(^•)

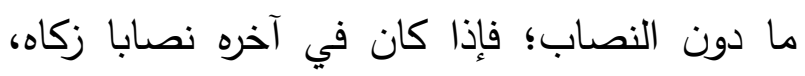

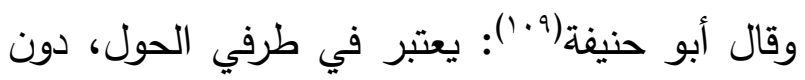

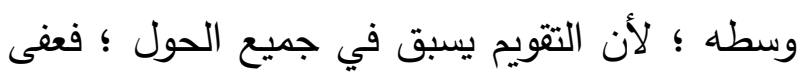
عنه، إلا في آخره ؛ فصار الاعتبار به، ولأنه يحتاج إلى أن تعرف قيمته في كل وقت ؛ ؛ ليعلم أن قيمته

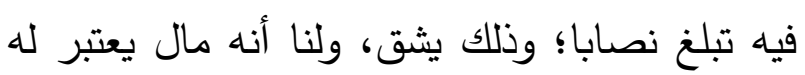

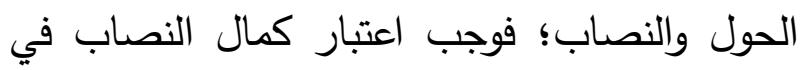

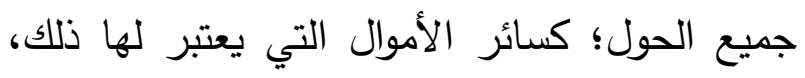

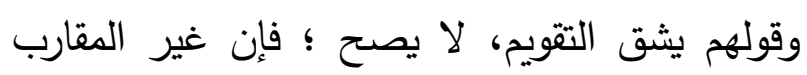

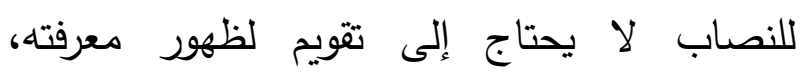
والمقارب للنصاب إن سهل عليه التقويم، وإلا فله الأداء، والأخذ بالاحتياط؛ كالمستفاد في أثناء الحول، إن سهل عليه ضبط مواقيت التملك وإلا فله تعجيل

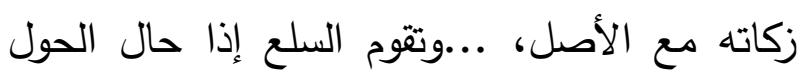

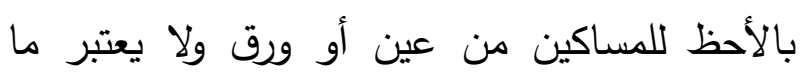
اشتريت به"(·').

وأعود الآن للحديث عن نصاب باقي أنواع المال

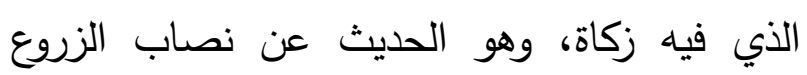
والثمار . الث

\section{ع - نصاب الزروع والثمار :}

تجب الزكاة في كل ما يقصد بزراعته نماء الأرض،

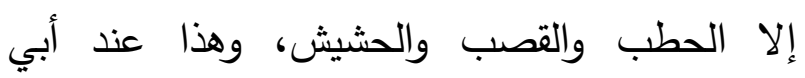

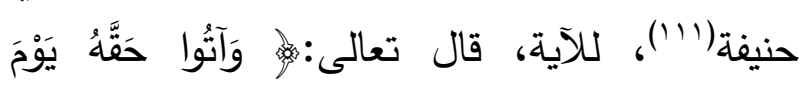

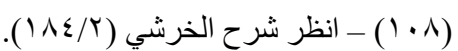

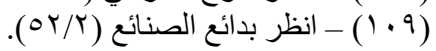

(11)

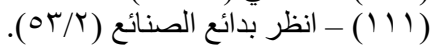

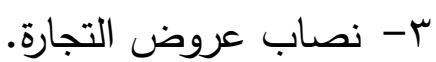

العُروض في اللغة : جمع عزض، وهو غير الأثمان

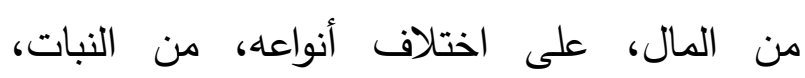

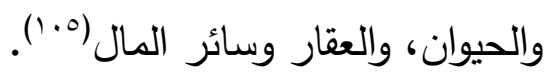

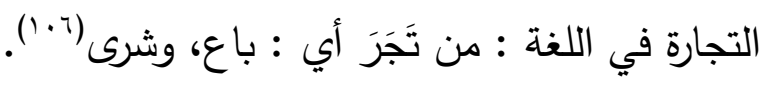

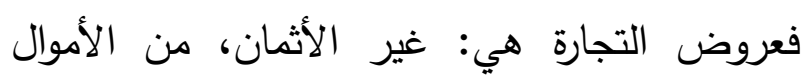
المتخذة من أجل البيع، والثراء. ونصاب ذلك، أن تبلغ قيمة ما يملكه التاجر من الئراه، العروض قيمة أقل نصاب من الثننين المذكورين آنفا، قال في المغني:" من كانت له سلعة للتجارة، ولا يملك غيرها، وقيمتها دون مائتي درهم؛ فلا زكاة عليه حتى يحول عليه الحول، من يوم ساوت مائتي درهم،

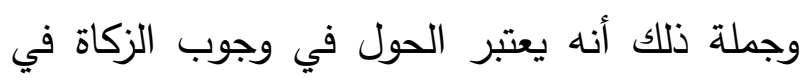
مال التجارة، ولا ينعقد الحول حتى يبلغ نصابا، فلو

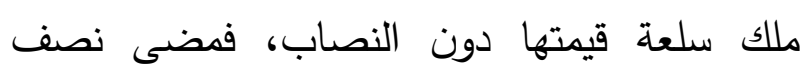

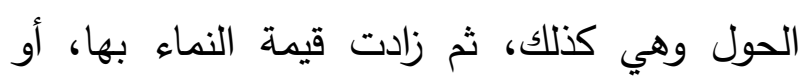
تغيرت الأسعار؛ فبلغت نصابا، أو باعها بنصاب، أو ملك في أثناء الحول عرضا آخر، أو أثمانا، تم بها النصاب؛ ابتدأ الحول من حينئذ، فلا يحتسب بما

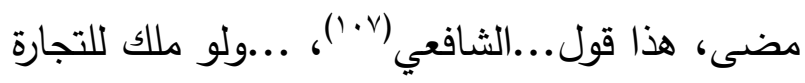
نصابا فنقص عن النصاب في أثناء الحول، ثم زاد

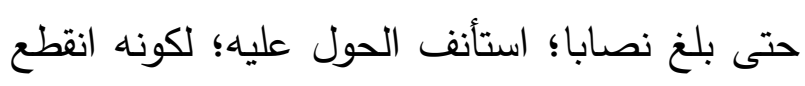

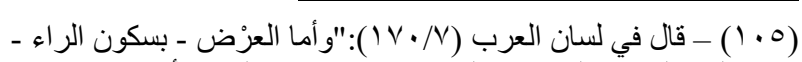

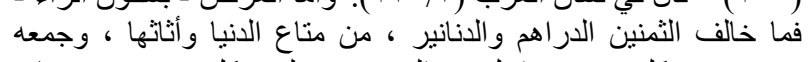

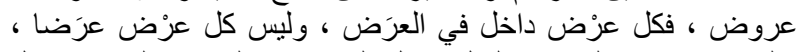

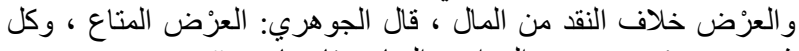
شيء هو عزض ، سوى الدرابه و الدنانير فإنهما عين".

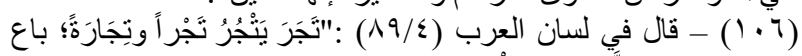

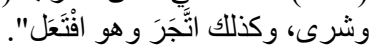

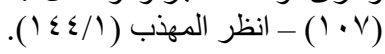


الحشيش، والحطب، والقصب، وهو أبو حنيفة،

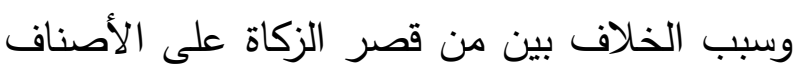

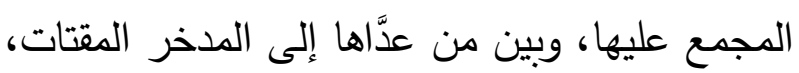

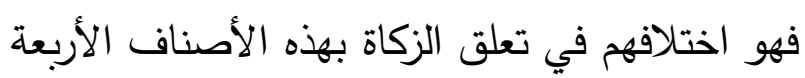

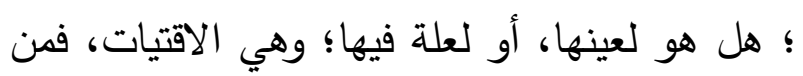

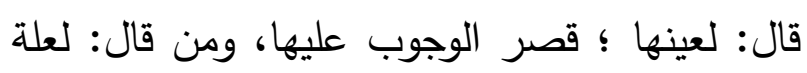

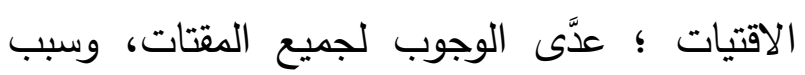
الخلاف بين من قصر الوجوب على المقتات، وبين

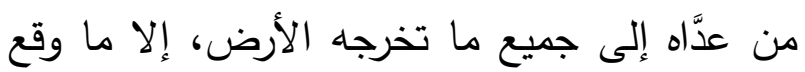

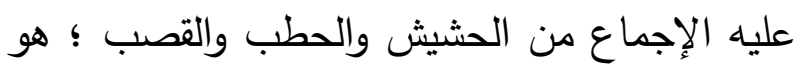

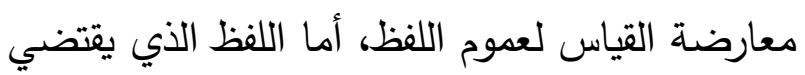

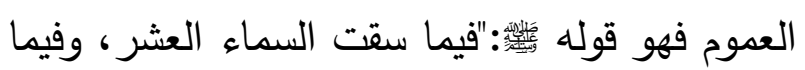

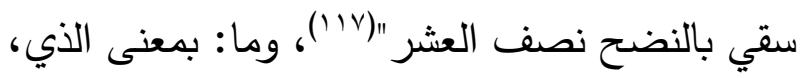

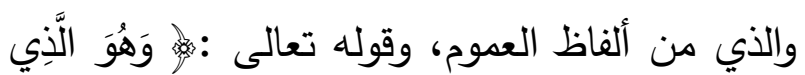

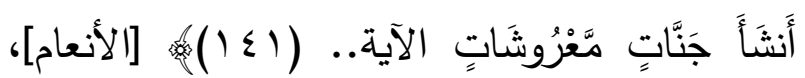

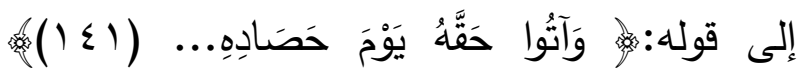
[الأنعام]، وأما القياس؛ فهو وَتوان أن الزكاة؛ إنما المقصود

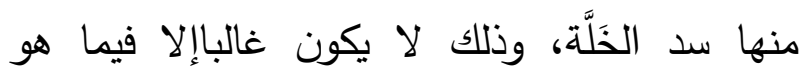
قوت، فمن خصص العموم بهذا القياس؛ أسقط الزكاة، مما عدا المقتات، ومن غلَّب العموم؛ أوجبها

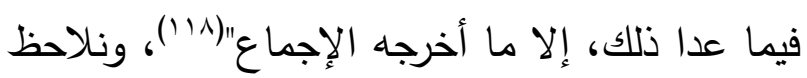

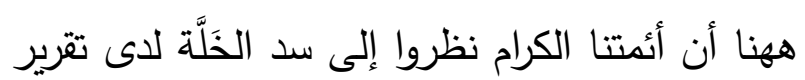

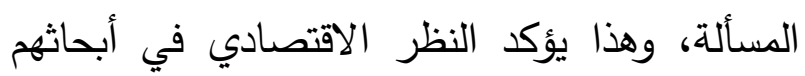

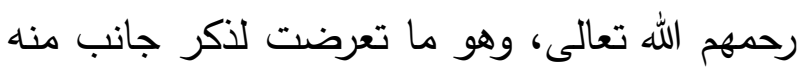

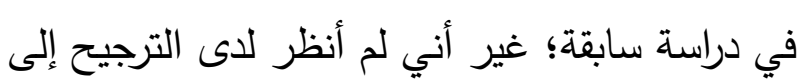

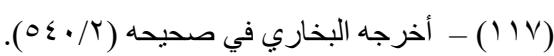

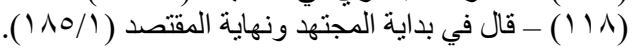

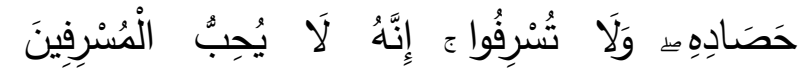

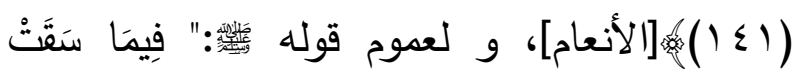

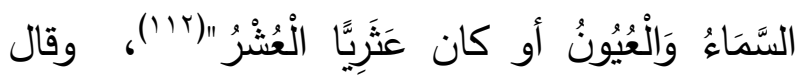

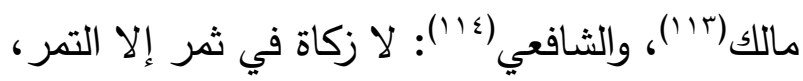
التمر، والزبيب، ولا في حب إلا ما كان قوتا، وأما الحنابلة(10) فقالوا: تجب وليب، في كل ما أخرج الله عز وجل، من الأرض، مما ييبس، ويبقى، مما يكال.

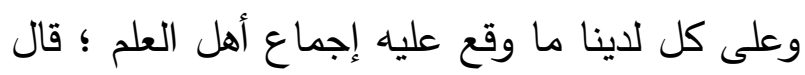

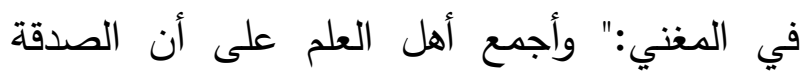
واجبة في: الحنطة، والثعير، التمر، والزبيب، قاله اله

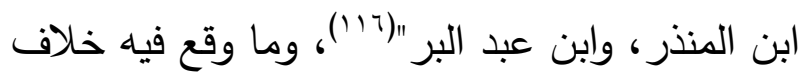

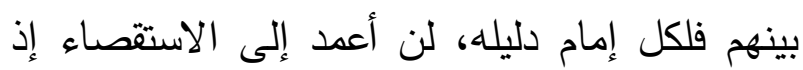

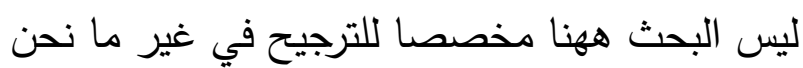

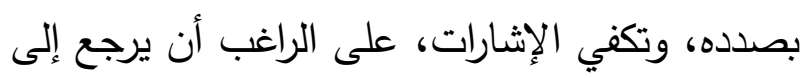

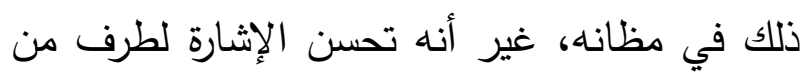
الخلاف وسببه، ولدى وجود نكت فريدة فإنني أذكرها دون المزيد من التقصلات، قال ابن رشد :"اختلفوا

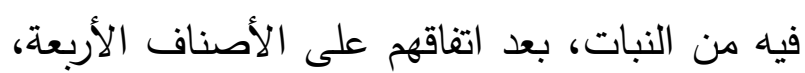
التي ذكرناها، فهو جنس النبات الذي تجب لبـ فيه الزكاة، فمنهم من لم ير الزكاة إلا في تلك الأربع لتهن

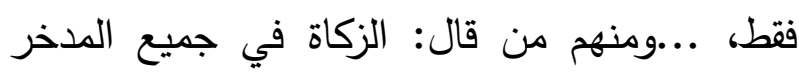
المقتات من النبات، وهو قول مالك والثافعي، ومنهم

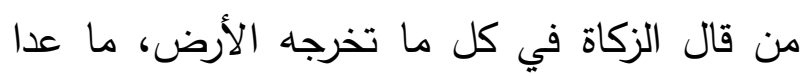

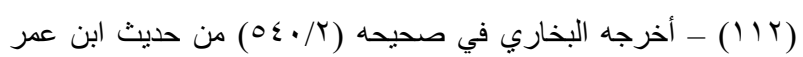
رضي الله عنهما.

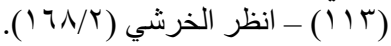

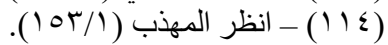

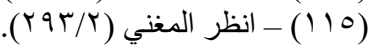

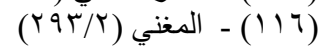


فأكثر ؛ لأن المحصول الذي يقل عن تلكم الكمية داخل في حد منفعة صاحبه لسداد حاجته، وما كان

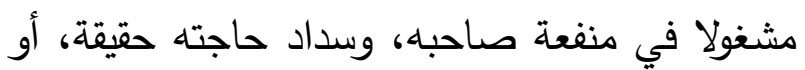

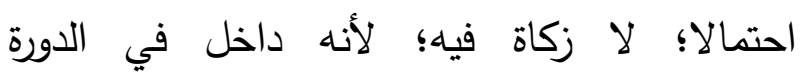

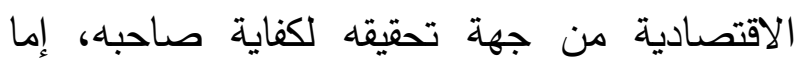

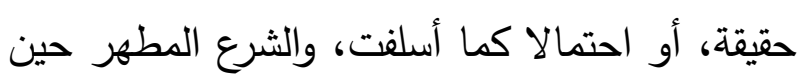

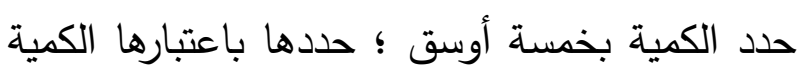

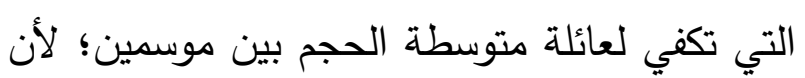

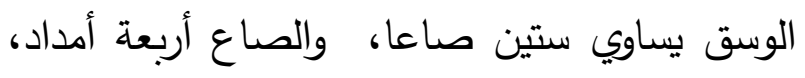

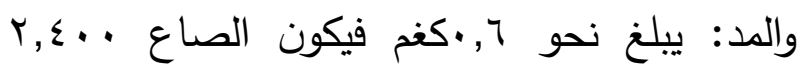
كغم، فيكون الوسق ؟ ؟ اكغم، فإذا كانت العائلة

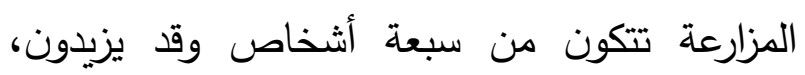
وكانت الفترة الفاصلة بين موسمين هي 9 أشهر ؛ نجد أنه قد تم تخصيص ك, بكغم من هذا الزرع للشخص شهريا، وقد تقل الكمية المخصصة التي يعفى عنها في الزكاة عن حد كفاية الشخص بين موسمين؛ فيجوز حينها أن يستسلف الرجل كمية

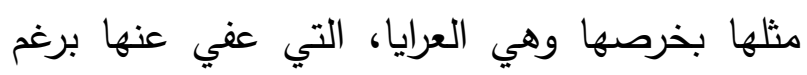

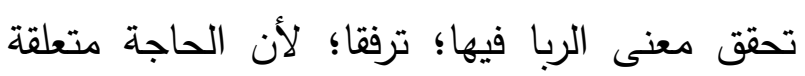
بمثل هذه الكمية؛ التي لا تعمل فيها الزكاة أيضا،

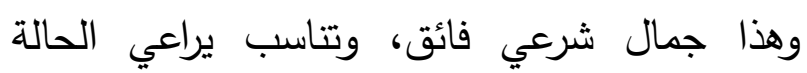

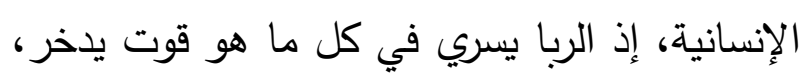
ويترخص في حالة فقده بكمية قليلة تباع بخرصها، في حدود الكمية التي هي عفو فلا زكاة فيها وهي حين يكون المحصول أقل من خمسة أوسق"(rا')،
ما يتصل بهذا الجانب، وإنما نظرت إلى أثر ذلك

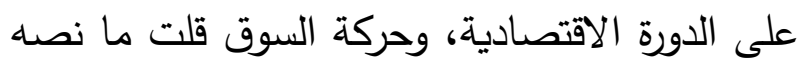

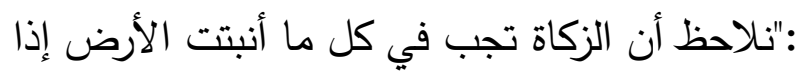

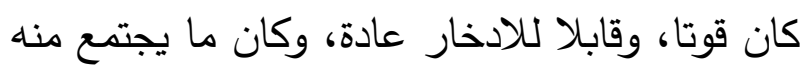
لاى صاحبه خمسة أوسق فأكثر ، ولا يكفي أن يكون

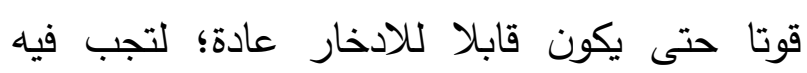

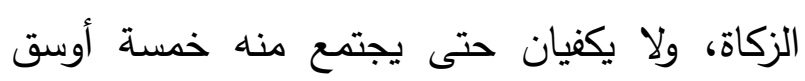

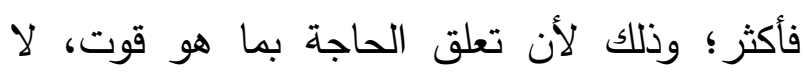

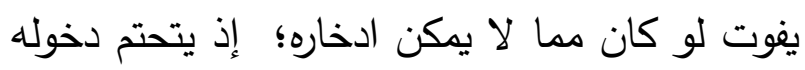

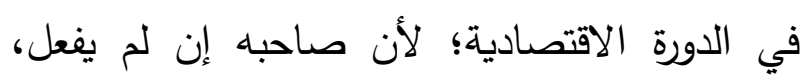

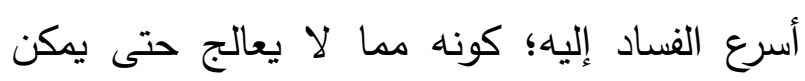

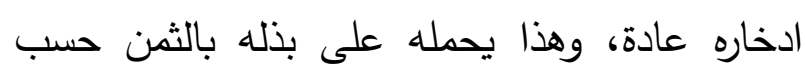

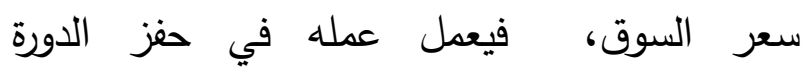
الاقتصادية ؛ فيصح أن لا زكاة فيه، وقد عبر في في في في

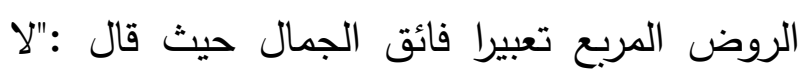

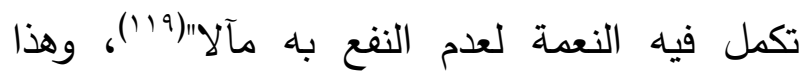

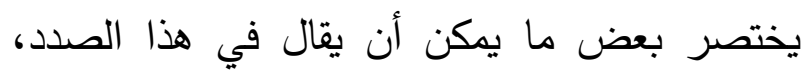

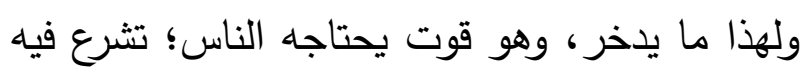

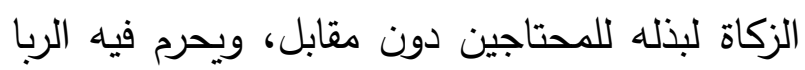

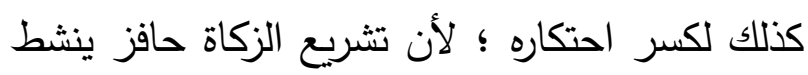

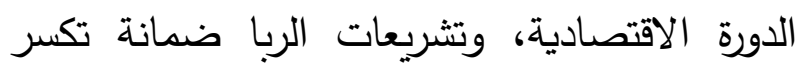

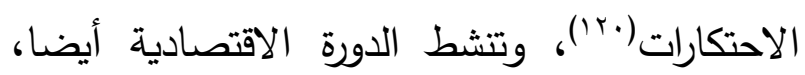

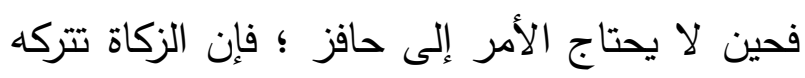

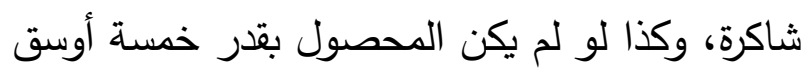
119 ـ منصور بن يونس البهوتي - الروض المربع (ص س آץ) - مكتبة

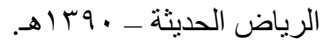

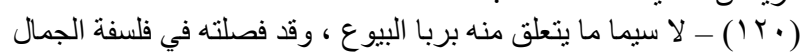

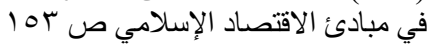


أواق صدقة"("r)"، ولأنه مال تجب فيه الصدقة فلم تجب في يسيره كسائر الأموال الزكائية، وإنما لم لمان يعتبر الحول، لأنه يكمل نماؤه باستحصاده لا ببقائه، لهائه

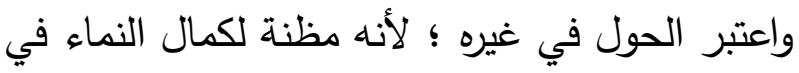

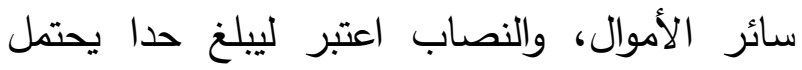
المواساة منه، فلهذا اعتبر فيه، يحققه أن الصدقة إنما تجب على الأغنياء، بما قد ذكرنا فيما تقدم، ولا يحصل الغنى بدون النصاب، كسائر الأموال الزكائية"(rr)، وكما أسلفت ليس الترجيح في المسألة من غايتي في هذا البحث، في غير ما نحن بصدده،

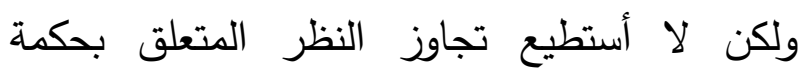
التشريع التي ذكرها ابن قدامة وعلى نحو يصل إلى لهاري

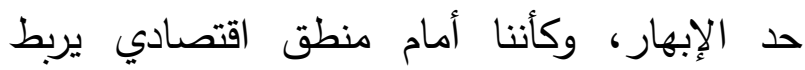
الأحكام والتشريعات (القوانين) بأسبابها المعقولة، ومعانيها المنطقية، وقد أبنت عن شيء من هذا في النقل الذي أسلفت بذكره من كتاب فلسفة الجمال، فلا

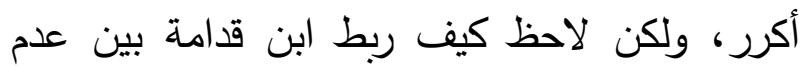
اشتراط الحول والزكاة ههنا، إذ الربط الحولي إنما لحان إنها كان من أجل تحقق كمال النماء في الأموال الحولية،

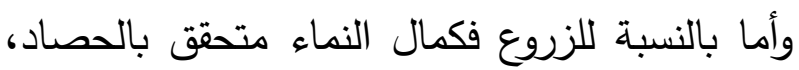

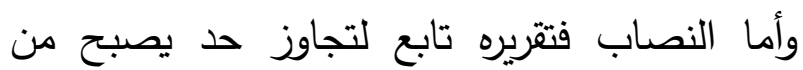
المناسب مواساة الناس فيما زاد منه، فلا تتعلق

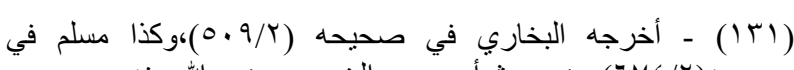

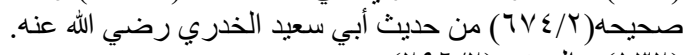

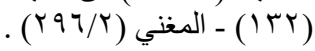

الفكرة آنفا تلم لك أشتات المسألة وتقررها على نحو

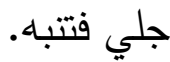
وأما النصاب فهو محدد بخمسة أوسق فصاعدا، وعندها فيها العشر إن كان سقيه من السماء، والسوح، وإن كان يسقى بالدوالي والنواضح وما فيه

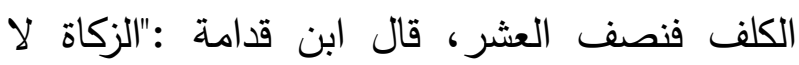
تجب في شيء من الزروع، والثمار؛ حتى تبلغ خمسة أوسق، هذا قول أكثر أهل العلم منهم:...

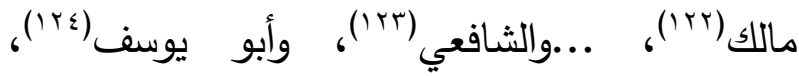

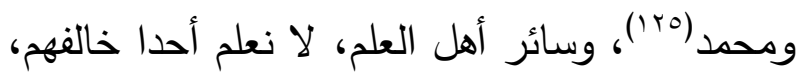

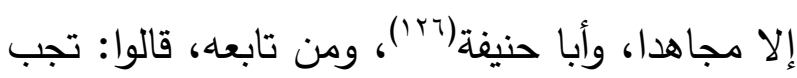
الزكاة في قليل ذلك وكثيره ؛ لعموم قوله واله

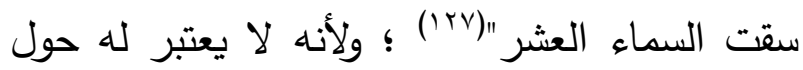

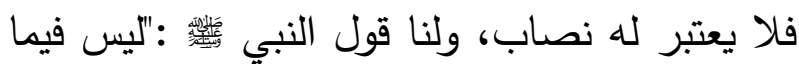

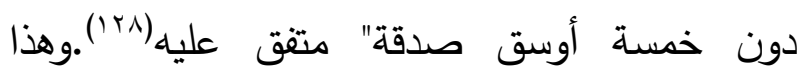
خاص ؛ يجب تقديمه، وتخصيص عموم ما رووه به، كما خصصنا قوله في سائمة الإبل الزكاة، بقوله

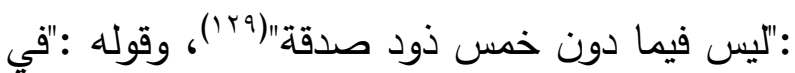
الرقة ربع العشر"(·rا")، بقوله :"ليس فيما دون خمس دون

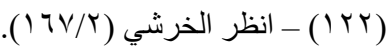

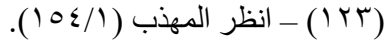

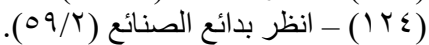

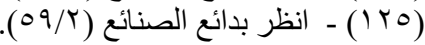

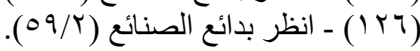

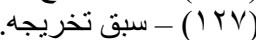

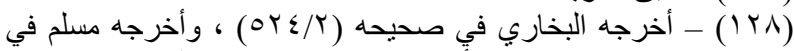

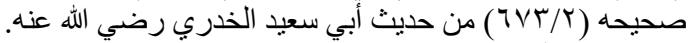

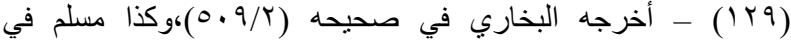

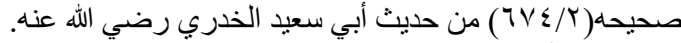

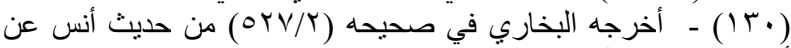
أبي بكر رضي الله عنهما. 
كالرصاص، والحديد، والنحاس، دون غيره(rr|)، وقال

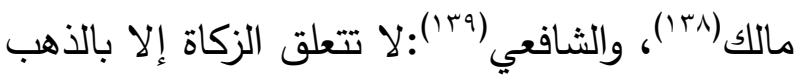
والفضة. فمتى تم استخراج تلك المعادن، على الصفة التي حددها كل مذهب، وتمت تصفيتها من الثوائب،

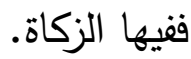
هذا ولم تشترط المذاهب الأربعة مضي الحول، وإنما يخرجها متى تمت التصفية، كزكاة الزروع والثمار؛ قال ابن قدامة :"ولا يعتبر له حول، وهذا

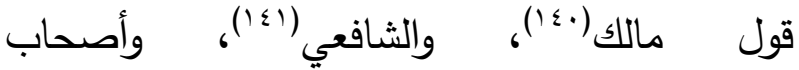
الرأي (r\& (....لأنه مال مستفاد من الأرض؛ فلا يعتبر في وجوب حقه حول،كالزرع والثمار، والركاز ، ولأن

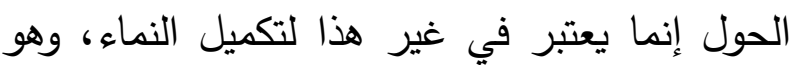
يتكامل نماؤه دفعة واحدة؛ فلا يعتبر له حول؛ كالزروع، ...إذا ثبت هذا فلا يجوز إخراج زكاته إلاه لهاه

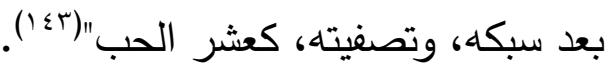
وأما النصاب فلم يشترطه الحنفية، وأوجبوا الخمس وندئه من كل أوجبوا فيه الزكاة من المعادن (؛؛ ().

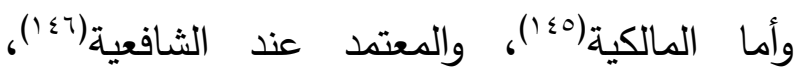
فجعلوا الزكاة في المستخرج من الذهب والفضة، متى

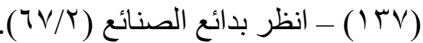

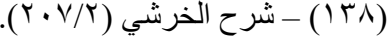

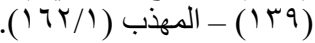

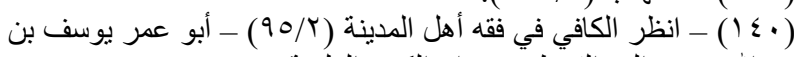

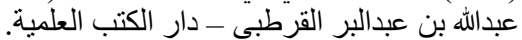

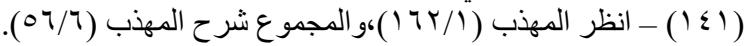

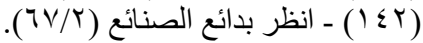

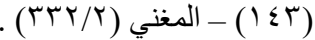

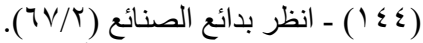

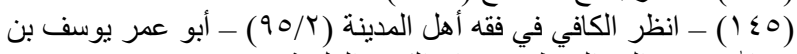
عبدالله بن عبدالبر القرطبي - دار الكتب العلمية.
مواساة الناس، والحال أن المزارع ذاته لا يجد كفايته، وعلى نحو تقديري سبقت الإثارة إليه(rrا'). وأعود الآن للحديث عن نصاب باقي أنواع المال الذي فيه زكاة، وهو الحديث عن نصاب المعدن.

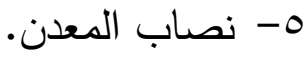
المعدن في اللغة من:عَدَنَ، يقال: عَدَنَ فلان

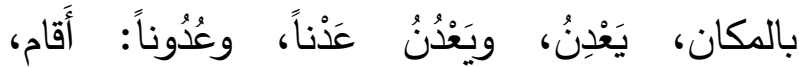

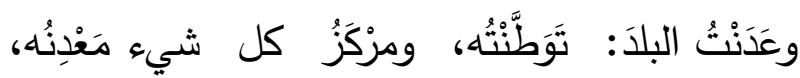

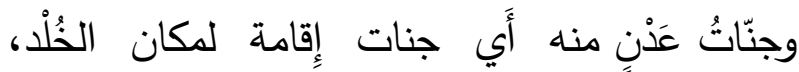

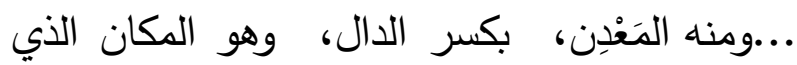

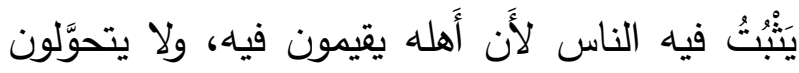

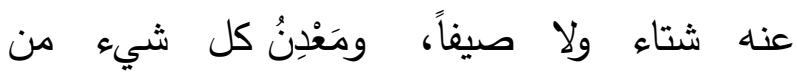

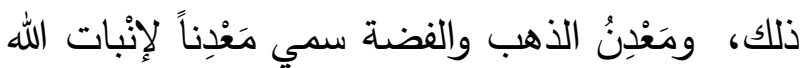

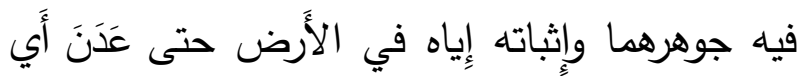
ثبت فيها (بكان) وفي الاصطلاح هو: كل ما خرج من الأرض، مما يخلق فيها من غيرها، مما له قيمة، من الحديد، والياقوت، والكحل، وكذلك المعادن الجارية كالقار ، والنفط، والكبريت، ونحو ذلك (ror).

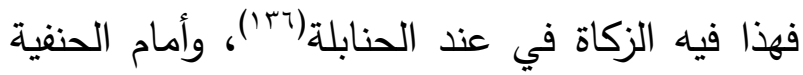
فيرون أن تعلق الزكاة إنما يكون بكل ما ينطبع

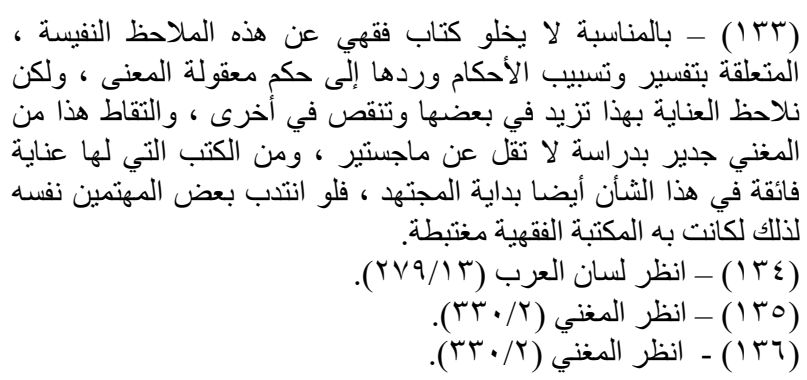


ما ذكرته آنفا مجرد إشارات، ولأئمتنا تفصيلات في هذا الباب، ليس هذا البحث مكانا لذكرها، وأكتفي بما سبق حفاظا على القصد من الدراسة. الفصل الثاني

$$
\text { تعريف المهني }
$$

وإمكانية تخريج المهنة طبقا لفقه الزكاة

وأقوال الفقهاء بثأنه، ومتى تجب عليه الزكاة

ومدى جواز فرض الضريبة عليه

والفرق بين الضريبة والزكاة.

الفصل الثاني

تعريف المهني، وإمكانية تخريج المهنة طبقا لفقه الزكاة

وأقوال الفقهاء بثأنه، ومتى تجب عليه

الزكاة،ومدى جواز فرض الضرببة عليه

والفرق بين الضريبة والزكاة.

المبحث الأول:تعريف المهني.

المهني في اللغة، من المهنة، وهي تأتي على معان عدة، ومنها: الخدمة، وهو المقصود ههنا قال في لسان العرب:" المهنة: الخدمة، و و مهنهم أي: خدمهم، ...وامتهنت الثيء: ابتذلته، ويقال: هو في

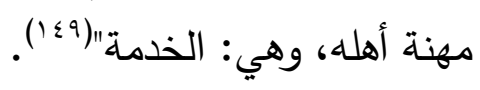

وفي الاصطلاح: الجهد المبذول فكريا أو بدنيا لتحقيق منفعة مشروعة(10.).

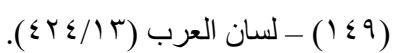

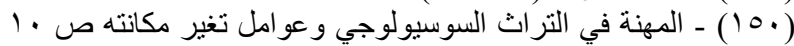

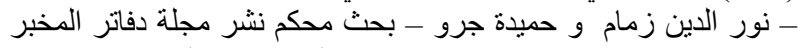

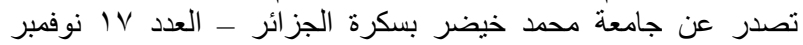

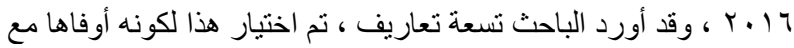
الاختصار من وجهة نظري.
بلغ المجموع منهما بعد التصفية نصابا، وأوجبوا ربع

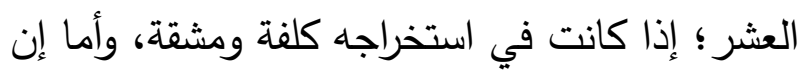

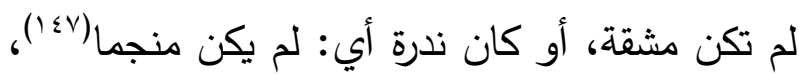

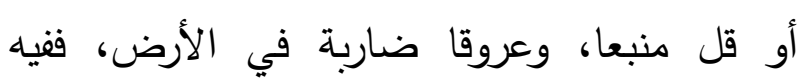

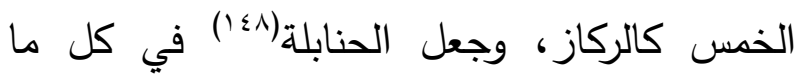
يخرج ربع العشر بلا تغريق.

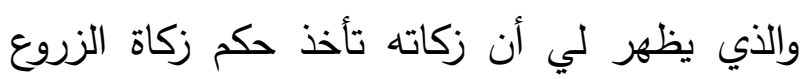

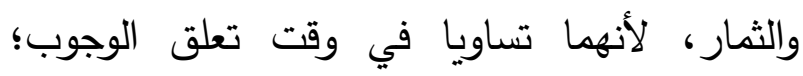

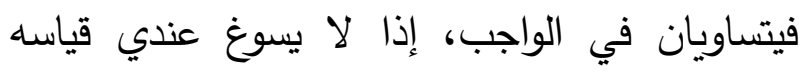
بالثمنين؛ لأن المعدن ليس كذلك، حتى حين يكون لوان

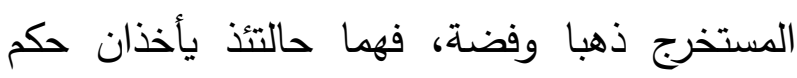
سائر المعادن، والثمنية فيهما لا تتحقق قبل التنقية،

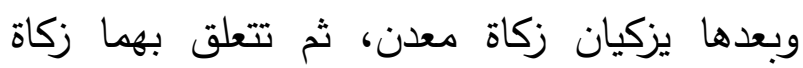

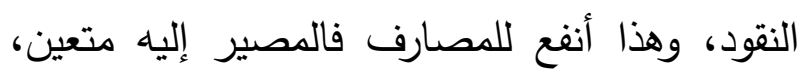

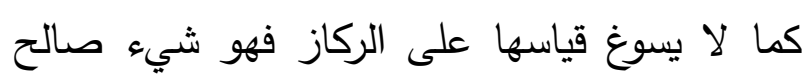
للاستعمال ولا يفتقر لمزيد جهد ليصلح لهذه الغاية؛

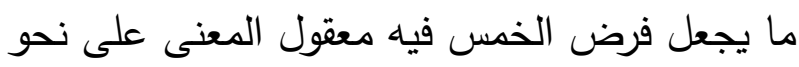
لا يتوفر في المعدن، إذا كان ما سبق صحيحا؛

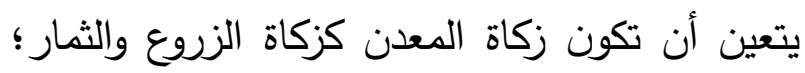

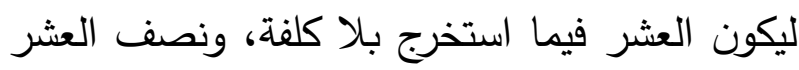
فيما استخرج بكلفة.

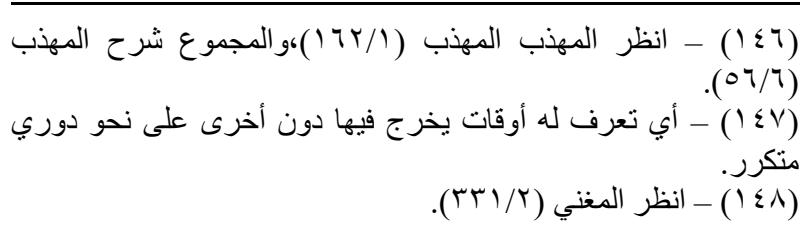




\section{المبحث الثاني:إمكانية تخريج(هام) المهنة طبقا} لفقه الزكاة، وأقوال الفقهاء في المسألة، ومتى

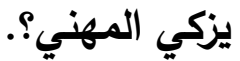

لا توجد أمكانية لتخريج المهنة طبقا لأي باب من أبواب الزكاة، فلم أجد في كتب الفقه ما يفيد بوجوب لاب لابد الزكاة على المهني، لا في ما يقتنيه من الأدوات، ولا في العوائد النقدية التي يحصل عليها، والمهن قديمة بقدم التاريخ، ولو وجد ما يوجب الزكاة بشأنها ؛ لم يكن ليخفى، بل اتفق أئمتنا كما يقول ابن رشد ألا زكاة في العُروض(10r) قال في بداية المجتهد :"اتفقا على ألا زكاة في العروض التي لم يقصد بها

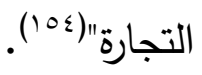

هذا وتختلف المهن، وتتنوع على نحو كبير جدا، فمن عمال المياومة الذين يعملون باليومية، إلى أرقى المهن، ومنهم من لا يكاد يجد قوت يومه، ومنهم من يجني المبالغ الطائلة في اليوم الواحد ؛ فهل يعقل ألا تفرض الثربعة على أي منهم الزكاة، لقاء ما يجنيه من عوائد؟ - من الجواب: إننا بتتبع كل تراثنا الفقهي، بدءا من كتاب

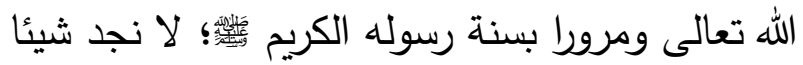
يوجب عليهم دفع أية زكوات لقاء أعمالهم، أو المبالغ التي يحصلون عليها.

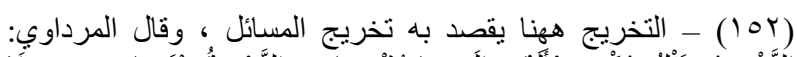

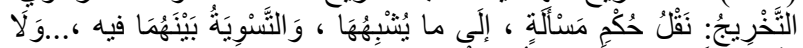

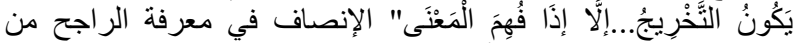
الخلاف على مذهب الإمام أحمد (1/7) - علي بن سليمان المرداوي دار إحياء التراث.

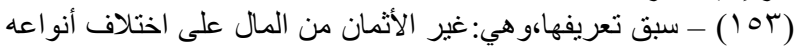
من النبات و الحيوان وان العقار وسائر المال. (10 (1) ) - بداية المجتهد ونهاية المقتصد (1) (1) ).
يظهر من التعريغين اللغوي، والاصطلاحي أن المهني يقدم خدمة، تعتمد أساسا على جهده وخبرته، وفي حالة وجود أدوات يستخدمها، فإنها تكون أدوات يقتيها لمصلحة إنتاج الخدمات، وهذا يعني أنني أتحدث حصريا عن المهن الحرة، التي يمارسها المرء دون خضوعه لجهة أخرى، تجارية أو خلافه. وعليه فلا صلة للمهني بالتجارة، ولا يصدق عليه اسم التاجر، وما يدخل على المهني بسبب عمله، لا يدخل عليه مقابل سلعة يبيعها، وسبق له أن جلبها، وهو شأن التاجر، وعرفت كتب الاصطلاح الفقهي التجارة على أنها :"عبارة عن شراء شيء ليباع بالربح"(101)، لاحظ ههنا الإضافة في عبارة(شراء شيء)، فمتى توفر شراء وبيع فهو تجارة، طالما ابتغى من ذلك الربح، وعليه سار التعريف القانوني، ورد في نظام المحكمة التجارية الصادر بالمرسوم

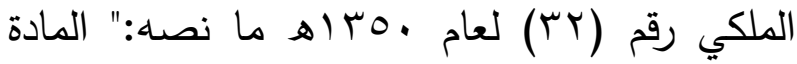
1:التاجر هو من اشتغل بالمعاملات التجارية واتخذها مهنة له، المادة ب:يعتبر من الأعمال التجارية كل ما هو آت: أ- كل شراء بضاعة أو أغلال أو مأكولات وغيرها لأجل بيعها بحالها أو بعد هد صناعة وعمل فيها. ب- كل مقاولة أو تعهد بتوريد أشياء أو عمل يتعلق بالتجارة بالعمولة أو النقل برا أو بحرا أو يتعلق بالمحلات والمكاتب التجارية ومحلات البيع بالمزايدة يعني الحراج..."، وهو ما عليه سائر القوانين.

العربي. (101) - التعريفات (VT/M) - علي بن محمد الجرجاني - دار الكتاب 
فحين يُعرض شيء على المهني، وتتنج عنه آثار سلبية؛ تعود على الناس بالضرر، ولا تحقق المقاصد الثرعية في حفظ الأموال، سيكون مشْرَعا أمام المغرضين نسبة هذا الخلل إلى الثريعة، ولكن حين تقرض على المهنيين إتاوات لا باسم الزكاة، فحينئ

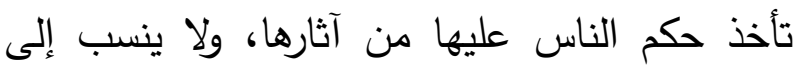
الثرع المطهر النقص لو ظهرت سلبيات، ولو ظهرت إيجابيات فذلك ما كنا نبغ، وليست الشريعة

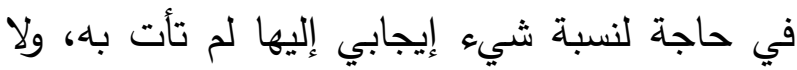

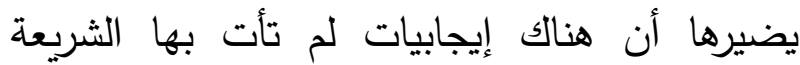
طالما أنها لم تمنعه في الأصل، ولا بأس بنسبة لهاب لهاب

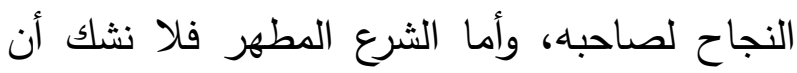
آثار ما يوجبه النافعة ستشهرها العيون وتدرك آثارها النفوس، وتتصلح بها البلاد قولا واحدا. وههنا قد يقول قائل: أليس في وجوب الزكاة على ولى ولى المكلفين، على تتوعهم ؛ مساهمة بطريقة، أو بأخرى

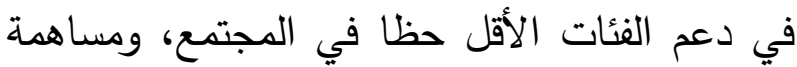
بطريقة، أو بأخرى في الاقتصاد ككل؛ فأين مساهمة المهنيين؟ أليس من الحكمة فرض الزكاة عليهر

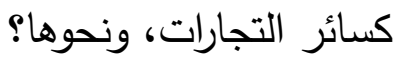

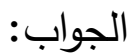

أولا: مساهمة المهني في الاقتصاد ظاهرة، لا خفاء فيها؛ لأنهم يقدمون خدمات تضيف الثيء الكثير؛ فهذا يعالج المرضى، وذلك يصمم منازلهم، وههنا من يبني بيوتهم، وهنالك من يصلح سياراتهم، وهذه مساهمات يدوية لا غنى عنها، وإضافات لم تكن
ولكن تجب الزكاة في الأموال المدخرة بأيديهم بعد مضي الحول؛ لأنها حينئذ مدخرات، وليس لأنهج أصحاب مهن، وهذه المدخرات النقدية تتعلق بها لهات الهان أحكام زكاة النقدين، وما هو في معناهما، بصفتها

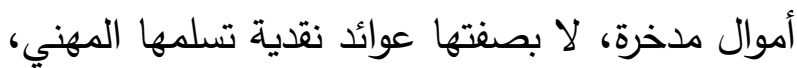

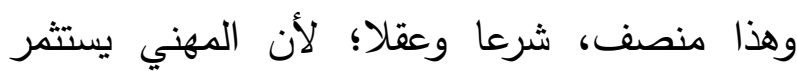
جهده وخبرته، وما يتسلمه موظف للحفاظ على حياته وحياة ذويه حياة كريمة، ومخصص للقيام على مصالحه مباشرة، فهي مبالغ تقاضاها من السوق، وهو يعيدها إليه، والثريعة الغراء ليست تفرض الزكاة إلا من أجل بقاء المال في دورته الاقتصادية، فلا تحبس الأموال، والأصل أن من شأنها أن تدور لمصلحة الكافة، فمتى ما كان دخل المرو مبذولا

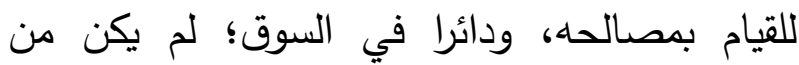
الإنصاف تحميله فوق ذلك، وأما لو تمكن المهني من الادخار؛ فهو لا يدخر إلا وقد تحققت له

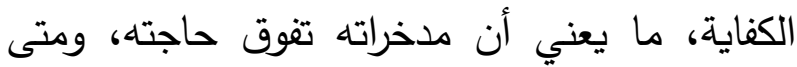
حال حول على تلك المدخرات النقدية تعلقت بها الزكاة بصفتها مدخرات لا بصفتها عوائد نقدية استفادها المهني، وإنما وجبت فيها الزكاة حينئذ كي لعاه تعيدها إلى تحقيق غايتها في الاقتصاد أعني غاية تلك المدخرات، وهي تتمية الاقتصاد ككل. وتجدر ملاحظة أن فرض شيء على المهني، وتسميته بالزكاة غير جائز شرعا؛ لأنه من قبيل نسبة شيء إلى الثريعة، وهو ليس منها، ما يحمِّل هيل الشريعة وزر خطأ قد يرتكب باسمها، وهي منه براء، 
مرتهنة ببذلها، متى طلبت، دونما تأخير، وإلا فاتت

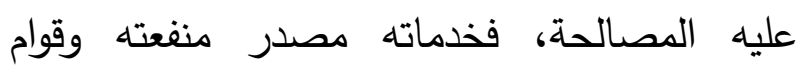
عيشه، ولهذا لا يصح القول وبصفة قاطعة: إن

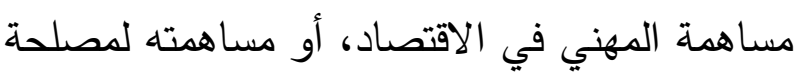

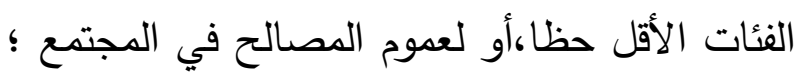

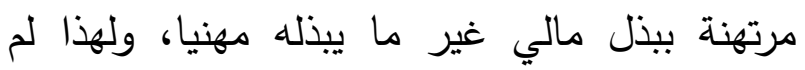

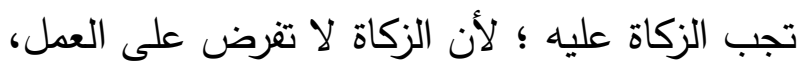

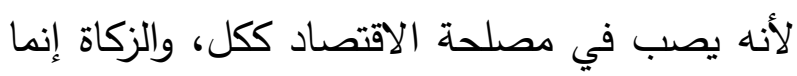
تفرض حال وجود خروج، أو احتمال خروج المال عن دورته الاقتصادية. ومع هذا وجد من يطالب بفرض إتاوات على دلى التى المهنيين، انسياقا وراء الفكرة آنفة الذكر، وحينئذ ينبغي أن نتنبه إلى عدم جواز تسمية ذلك بالزكاة، ولنكاء

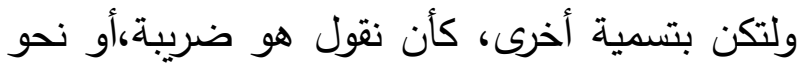

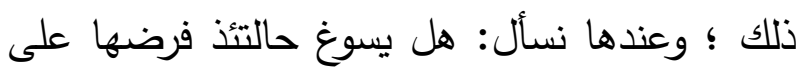

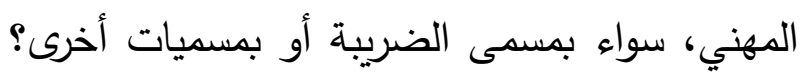
وهذا ما سيأتي بحثه.

المبحث الثالث: فرض الضريبة على المهني بلالا

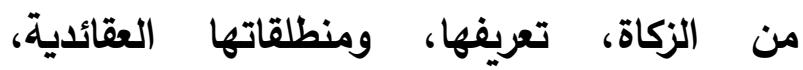
وأنواعها، ووظائفها، وحكمها وكيف ينبغي أن تكون

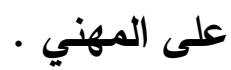
ليس هذا البحث مخصصا لتفصيل الكلام حيال الضريبة، وحسبي كلام مختصر يفي بالغرض،

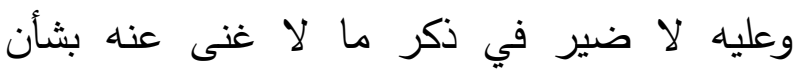
تعريف الضريبة لغة، واصطلاحا، وفلسفتها، وأنواعها، وأهدافها، وشروطها، وصولا إلى معرفة
المجتمعات لتعيش على نحو ميسر بدونها، وهي مساهمات مباشرة، وهي كافية من وجهة النظر ملئر الشرعية، ولو لم تكن كذلك لفرضت الثريعة عليهح

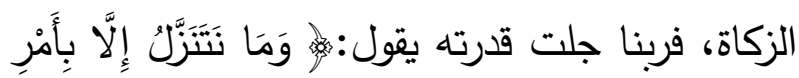

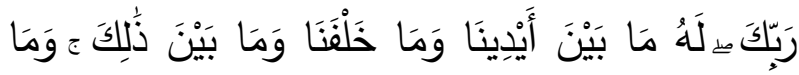

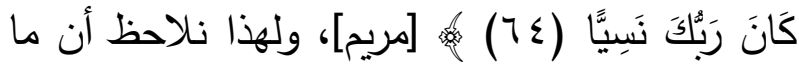

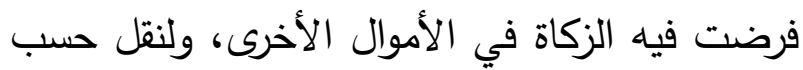

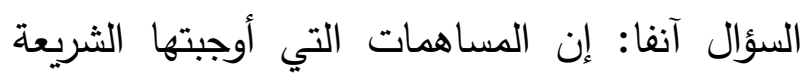

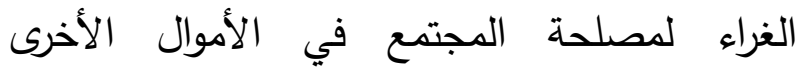
"الزكوية" ؛ فنلاحظها بصفقة دائمة تتوسط شيئا، لم

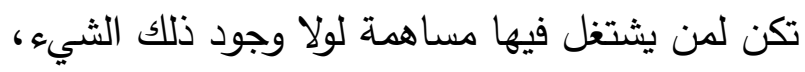
فالتاجر لن يسهم بشيء لولا السلع بيده، والمزارع

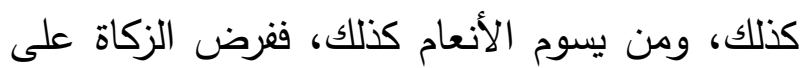

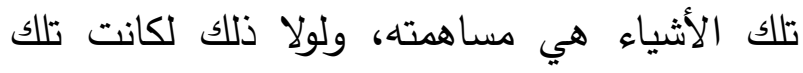
الأثياء تضيف إليه أكثر مما يعود على المجتمع منها، وعلى نحو كبير جدا، وبإمكانه تكديسها، بحيث لا يخرجها، أو يحتكرها بحبسها عن وقير وباه الوفرة،ويمكنه التربص بها لوقت الغلاء، فهي قابلة

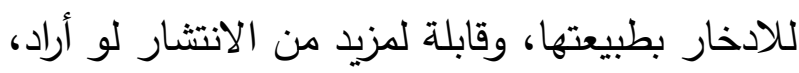

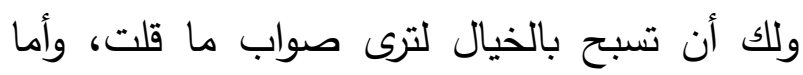

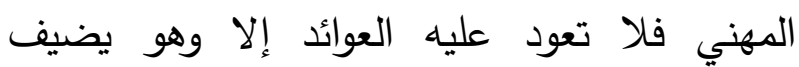
للمجتمع مثلها بل أكبر، ولو جاز لي فإني أرى أن

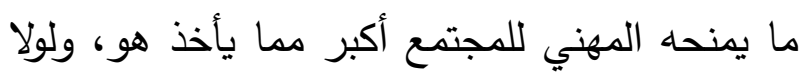

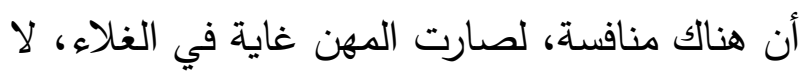
سيما الراقية منها، والتي تفتقر لخبرة خاصة يصعب تحصيلها، كما أنه لا يملك تكديسها، لأن منافعة 
الاقتصادية، والعقائدية، وهذا الفريضة القانونية، لا تقرض اعتباطا، بل لابد من قواعد، ومعايير محددة تفرض الضريبة على أساسها، وذه المعايير تتطلق من فلسفة الدولة، وعقائدها، ولعل أكثر موجه بشأن الضرببة هو المنطلق العقائدي، والاقتصادي ؛ فما ولها ما يحدد بعد ذلك تتوعها، وأسس فرضها، ولهذا سيكون الفرع الآتي مخصصا للحديث عن منطلقات الضريبة من خلال فلسفة الدولة العقائدية، والاقتصادية.

الفرع الثاني: منطلقات الضريبة من خلال فلسفة الدولة العقائدية والاقتصادية.

إن السلوك البشري بصفة عامة، يتأثر تأثرا بالغا

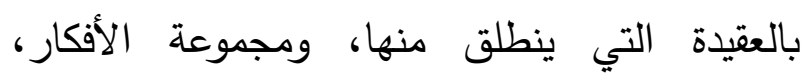
والقناعات التي تتكون منها تلك العقيدة ؛ توجهاء

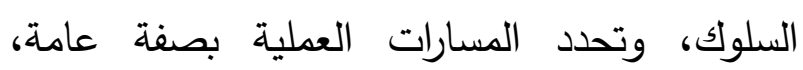
والاقتصادية بصفة خاصة.

ولست بوارد ذكر التفاصيل المرتبطة بذلك، وأكتفي

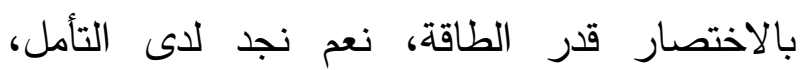
والاستقصاء بشأن العقائد، والأفكار التي وجدت في نهار العالم مما يحكم السلوك الاقتصادي من بعد،نعم:

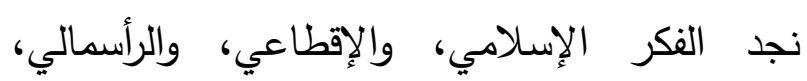
والشيوعي، والاشتراكي، والمختلط. وأقدمها وجودا هو الفكر الإسلامي لأنه وجد بوجود والاندراكي

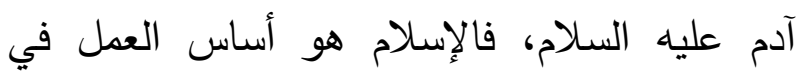

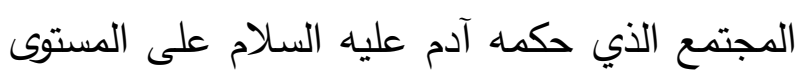

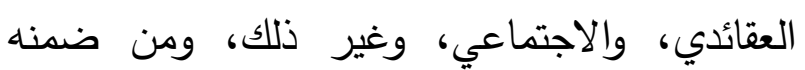

حكمها الثرعي، ثم إلى بيان موجز لأهم الفروق بينها وبين الزكاة، وكيف ينبغي أن تكون الضريبة

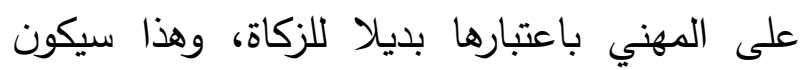
على فروع. الفرع الأول:تعريف الضربية. الضريبة لغة: من ضَرَبَ، وله معان كثيرة، قال في

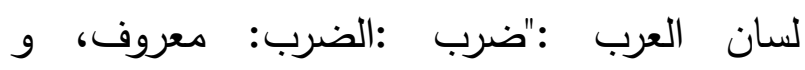
الضرب: مصدر ضربته، وضربه، يضرِبِه، ضربِا،

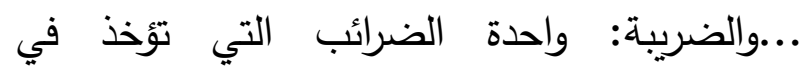
الأرصاد، والجزية، ونحوها، ومنه ضريبة العبد وهي: غلته"(100).

وفي الاصطلاح :"تعرف الضريبة بأنها: فريضة إلزامية، وليست عقابية، يلزم المكلفين الطبيعيين، أو الو المعنويين على أساسها؛ بتحويل بعض لإلى الموارد

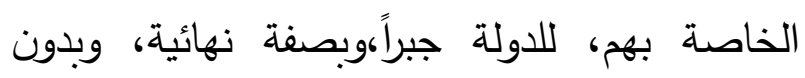
مقابل ؛ لتحقيق ما تسعى إليه الدولة من أهداف، طبقاً لقواعد، ومعايير محددة"(107). تتضح من التعريف مكونات الضريبة، وصنفاتها، فهي فريضة أي: فريضة قانونية إلزامية لمصلحة الدولة، بدون مقابل؛ وهذا الوصف الأخير يميزها

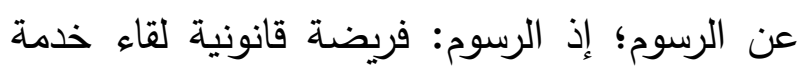

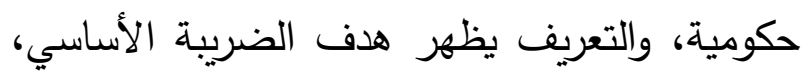

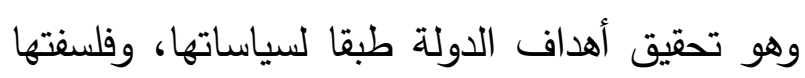

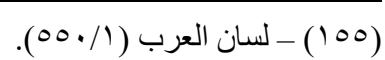

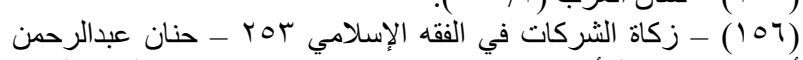

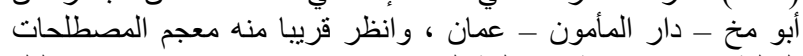

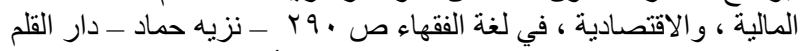

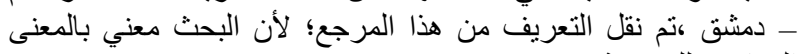
المعاصر للضريبة. 
من الرسل، وتقصير من المؤمنين بشأن الدعوة، والركون إلى الدنيا، فزين الثيطان لكثيرين تغيير عقائدهم، وأفكارهم، فززت الوثنية وقوي عودها، وصحب ذلك تمرد إنساني في جميع مناحي الحياة، فوجدت تشريعات أخترعها عباد الشيطان لتكري مصالحهم، وتم تمجيد القوة، والمال، فولد الإقطاع، الذي هو في الحقيقة: تحالف السلطة،والمال في نظام لا يبتعد كثيرا عن الرأسمالية، ثم بعد الثورة الصناعية، ولدت الرأسمالية، من رحم التعقيد الذ أفرزته الثورة الصناعية بسبب الانتشار الذي شهده العمل الصناعي والتجاري، على نحو لا يقل عن الزراعي، ما اسفر عن تغول كبير وقبيح للرأسمالية، مما أجد رد فعل لذلك أنجب فكرا مناقضا وهو الفكر الشيوعي، مع ما اسفر عنه من مقترح الاشتراكي وسيط تم افتراض وجوده تمهيدا للوصول إلى الفكر الشيوعي ؛ إذ لا يتصور الانتقال طفرة واحدة، من الرأسمالية إلى نقيضها الشيوعية، دون تدرج أو مرحلة وسيطة لتكون الاشتراكية هي تلك المرحلة الوسيطة(109)، غير أن البشرية وكرد فعل لتلاطم تلك فيط فئك الأفكار، وصلت لفكر مختلط، يمزج بين سائر الأفكار السابقة، ولا يتحيز لشيء منها، مع الاعتماد على الدراسات في تقرير الخيارات الاقتصادية، مع الحفاظ على مبادئ الفكر الرأسمالي إجمالا، وفي كل

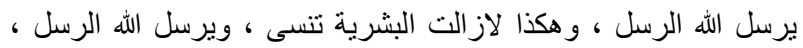

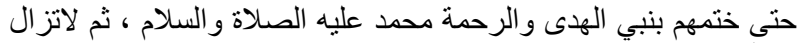
في أمته الرسالة محفوظة بحفظ الله تعالى ممثلا في القرآن العظيم والهيه السنة المطهرة. ( ) - (109) - مآتي لمزيد بيان.
الاقتصادي، فبرغم بساطة المكونات الاقتصادية

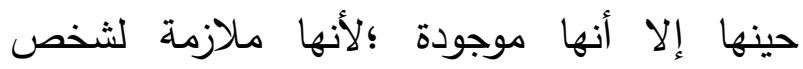

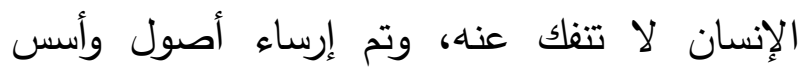
التعامل الاقتصادي من خلال آدم عليه السلام وتعلم ذلك بنوه، وهذا أقوله أخذا من كتاب الله تعالى وسنة رسوله الكريم عليه الصلاة والسلام، إذ ليست العقيدة مع جميع توابعها وليدة الفكر البشري، وإنما هو علم تعلمه آدم عليه السلام بتعليم ربه له، قال تعالى:

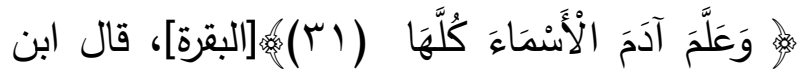
سِعْدي في تفسيره :"أي: أسماء الأشياء، وما هو مسمى بها، فعلمه الاسم والمسمى، أي: الألفاظ

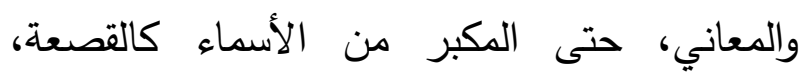

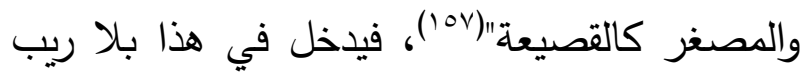
ما يتصل بالجوانب العقائدية، وما يتبعها من جوانب

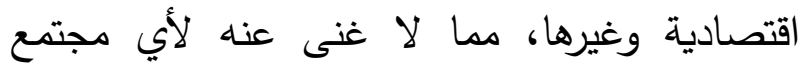

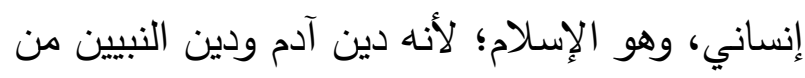

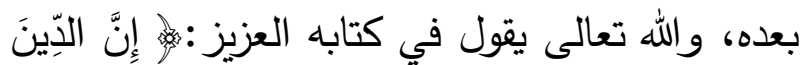

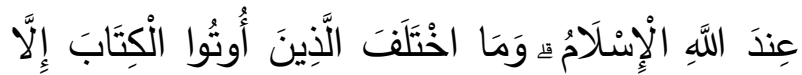

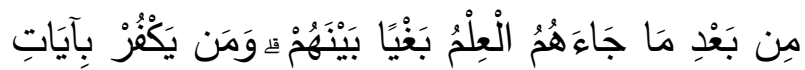

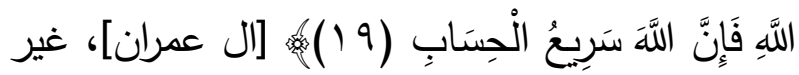

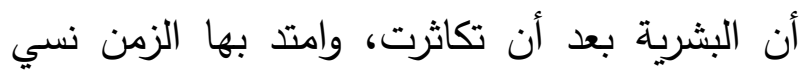
منهم من نسي، وتسربت إلى عقائدهم الخرافات

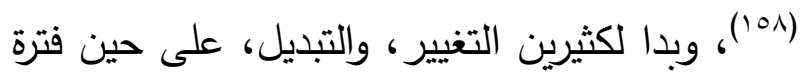

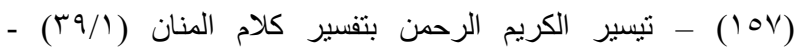
عبدالرحمن بن ناصر السعدي ـ تـ: عبدالرحمن لويحق المطيري ـ دار

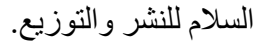

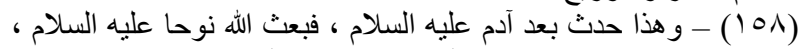

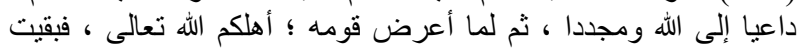

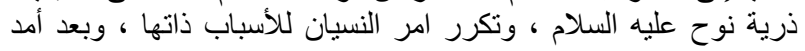


والقبيلة إنما بدأت بوجود أسر ذات أعداد قليلة، يعود ترأسها للجد، ثم تنزل إلى ابنه الأكبر، أو غيره

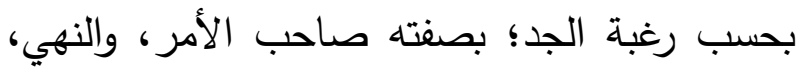
ولكون الجميع يخضع لسطوته، وكان يبسط سلطانه على الأراضي حوله، بقدر ما تصل إليه يده، وكانت الأرض هي أهم مصدر للإنتاج، وارتبطت الثروة الثانه والقدرة بحسب ما تمتد إليه اليد من ذلك، وكان يقسم

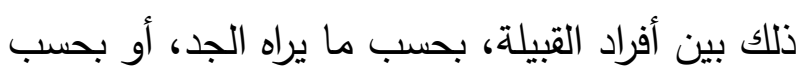
ما يراه كبيرهم الذي وصلت إليه الرئاسة، ويرتبط لئ لئه العطاء بمقدار ما يقدم ذلك الفرد لمصلحة القبيلة،

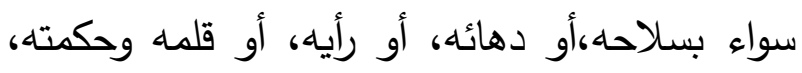

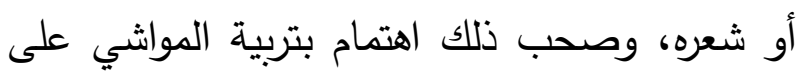

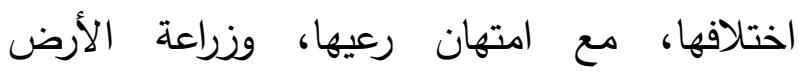
وفلاحتها، ولا يوجد ما كان يمنع من الصيد، وكل

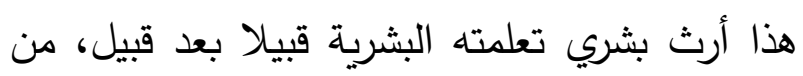

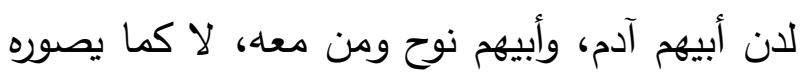
دارسو التاريخ البشري، إذ يقولون إن الإنسان بدأ

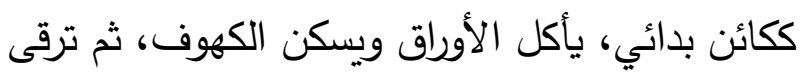

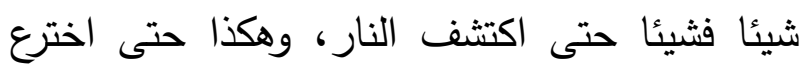

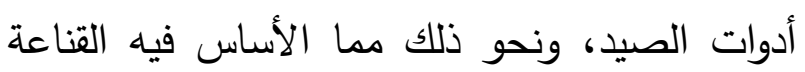
بأن الإنسان تطور عن غيره، لا أنه وجد كما هو الانيان

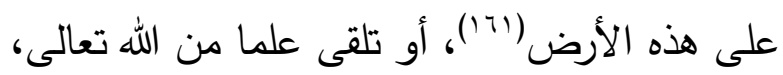

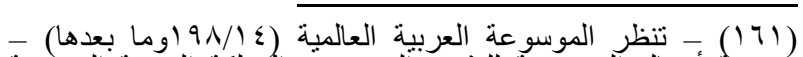

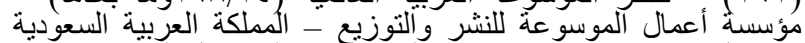

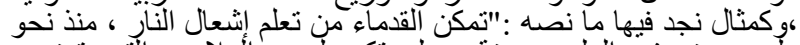

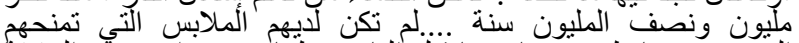

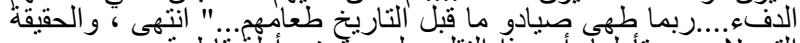

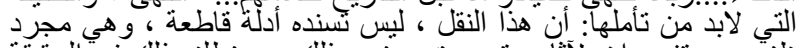

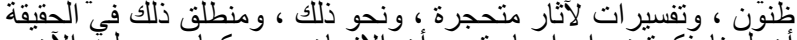

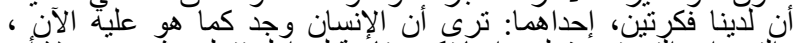

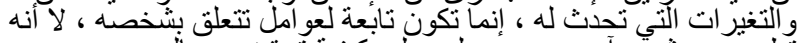

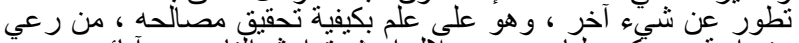

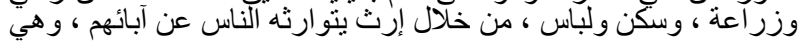

ذلك بقي النهج الإسلامي فريدا ومميزا، برغم اعتماده

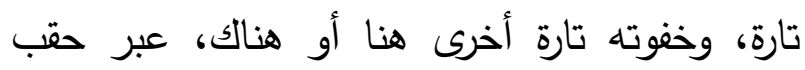
تاريخية مختلفة، وإليكم عبارات مختصرة عن كل اتجاه، من غير تفصيل يخرج بنا عن غاية البحث؛

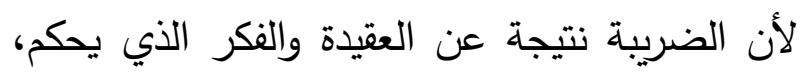
وليست وليدة ذاتها. أولا: النظام الإقطاعي: لم أجد من تحدث عن نشأة الإقطاع على نحو يفي الإطاعي:

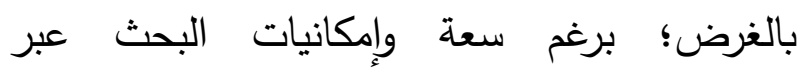
الإنترنت، وتم الحديث عنه باعتباره أمرا واقعا، بات والحقيقة أنه وجد ضمن سياق تاريخي، يرشد إليه

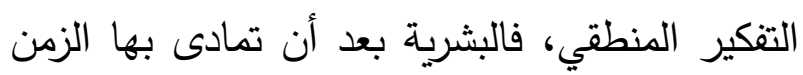

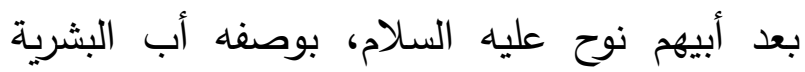

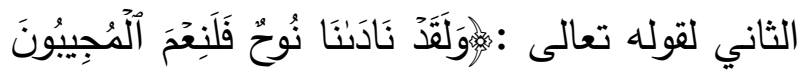

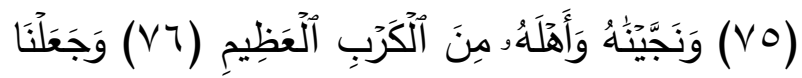

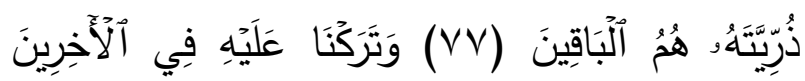

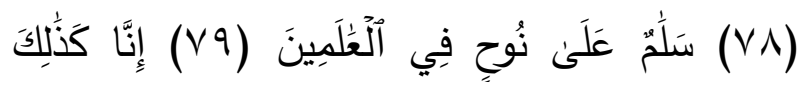

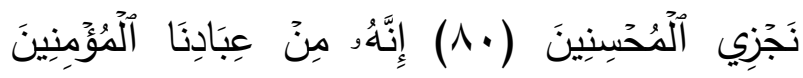

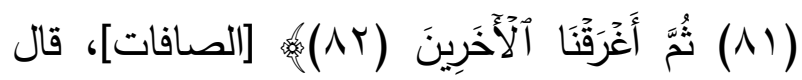

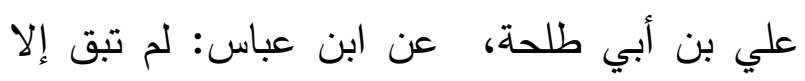

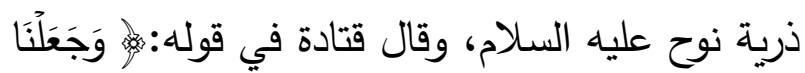

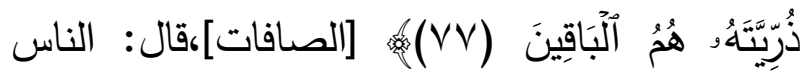
كلهم من ذرية نوح عليه السلام(17) ومن خلال النظر في طبائع الأمور يمكن أن نقول: إن الإقطاع وجد كنتيجة طبيعية لوجود سلطة القبيلة،

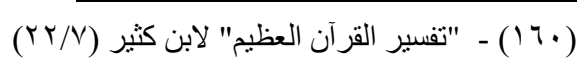


هذا أصلا، كما أن الخيارات كانت متاحة لمن لا

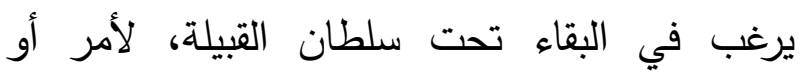

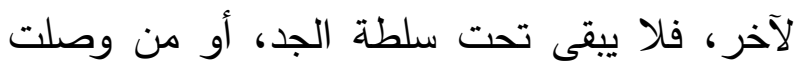

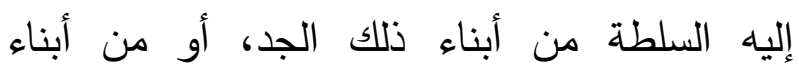

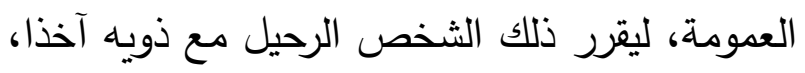
ما يمكن أن يحصل عليه، من مواش، وغيرها؛

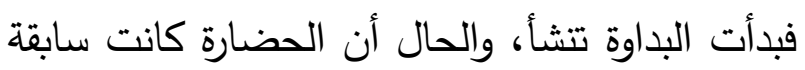

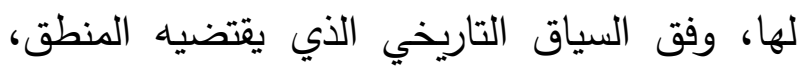

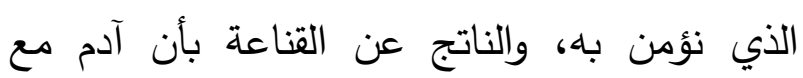
أسرته الأولى كان حضريا(بآ)، والبداوة طارئة،

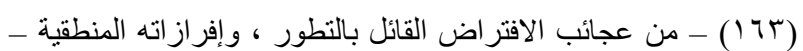

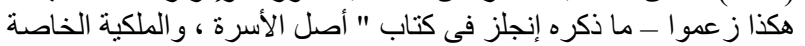

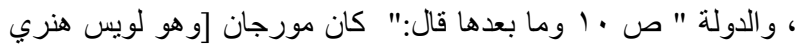

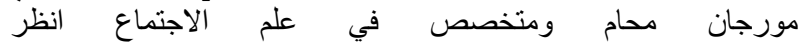
https://www.wikiwand.com/ar/\%D9\%84\%D9\%88\%D9\%8A\% D8\%B3 \%D9\%87\%D9\%86\%D8\%B1\%D9\%8A \%D9\%85\% [D9\%88\%D8\%B1\%D8\%BA\%D8\%A7\%D9\%86

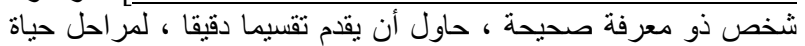

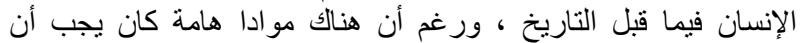

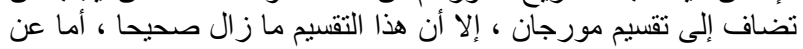

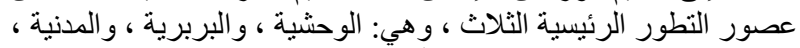

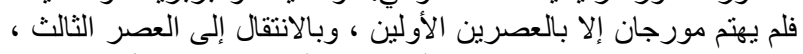

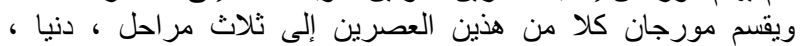

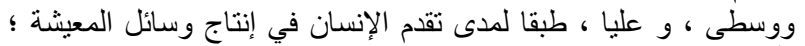

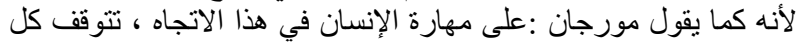

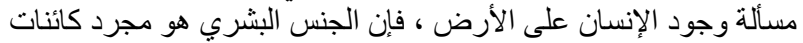

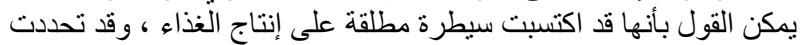

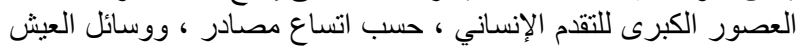

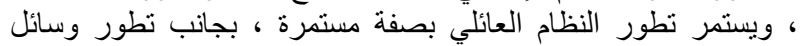

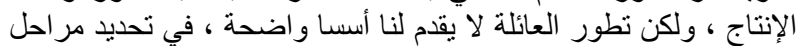

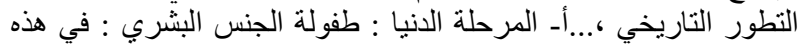

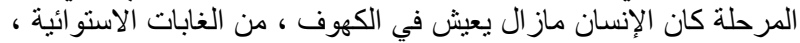

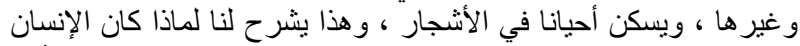

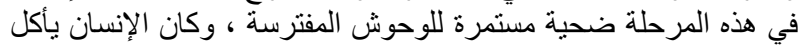

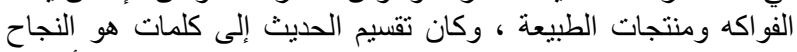

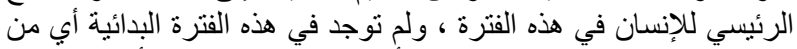

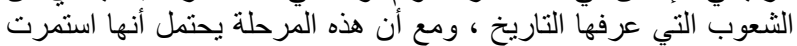

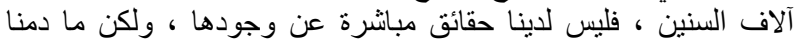

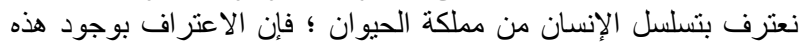

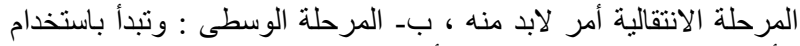

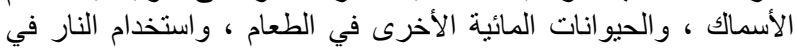

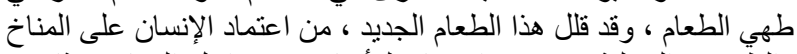

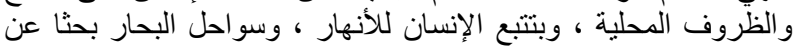

أو أنه صنع بيتا(Trا) حين نزل إلى الأرض، فهو

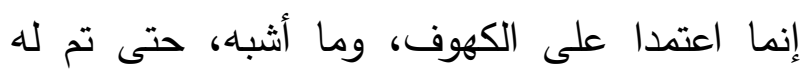
فجأة اكتثاف كيف ييني فبنى البيوت وسكنها، وإلا

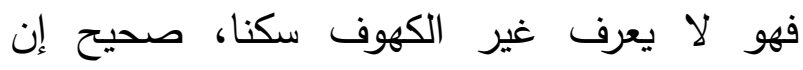
الإنسان سكن الكهوف، ونحوها، ولكنه كان خيارا متاحا وليس الخيار الوحيد، وليس لأنه لا يعرف ولهن

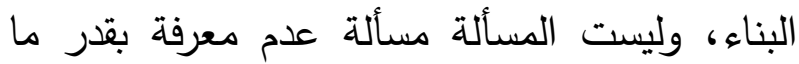
هي مسألة اختيار، ولا يوجد ما يكفي للقناعة بغير لئل

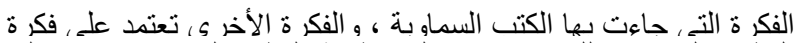

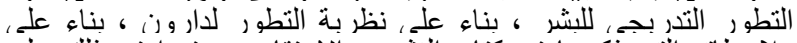

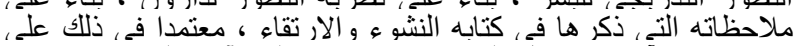

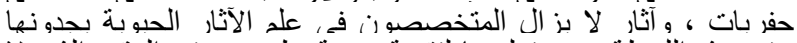

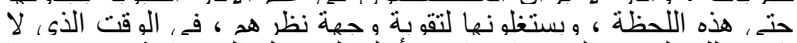

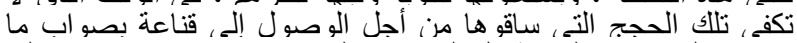

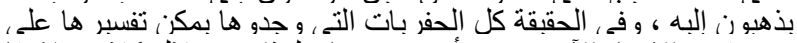

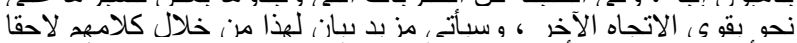

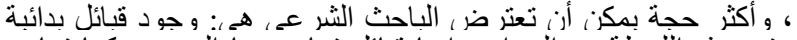

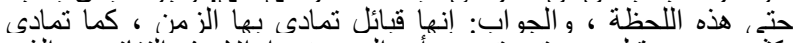

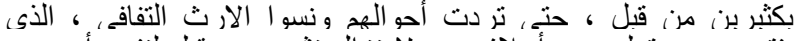

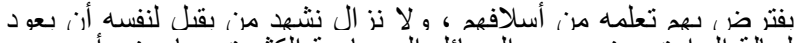

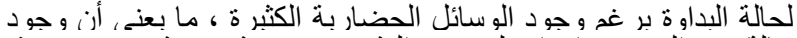

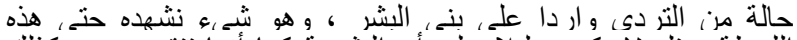

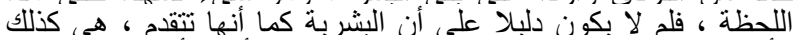

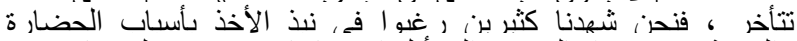

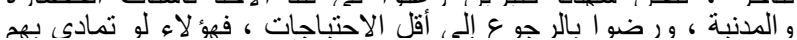

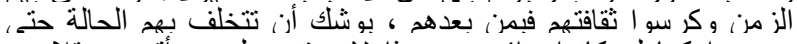

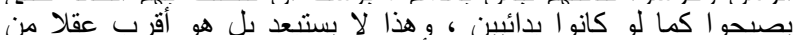

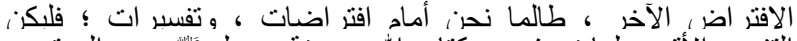

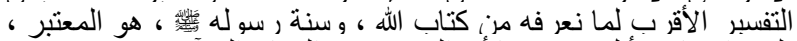

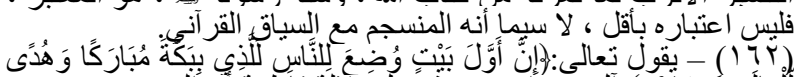

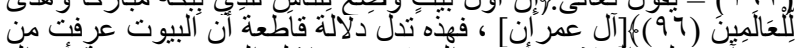

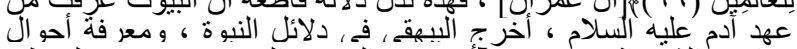

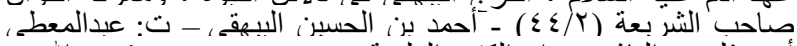

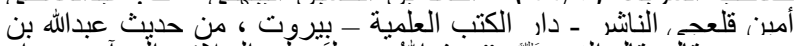

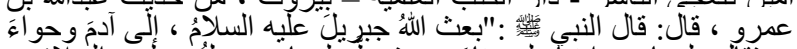

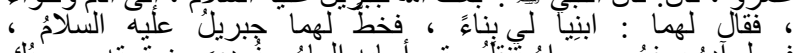

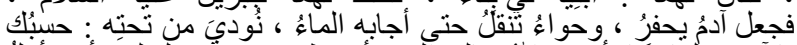

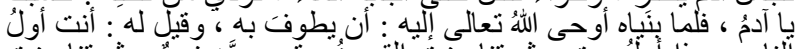

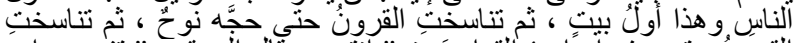

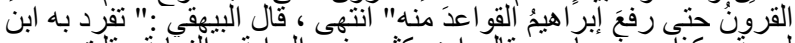

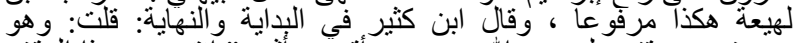

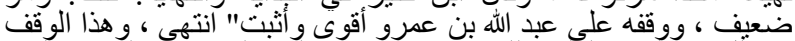

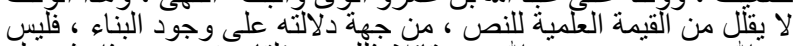

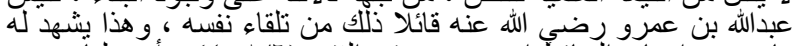

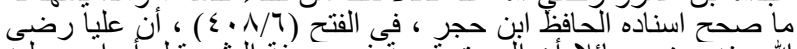

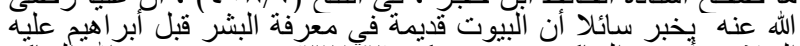

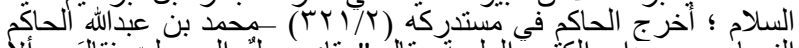

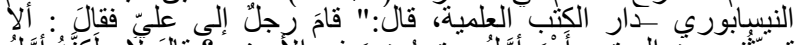

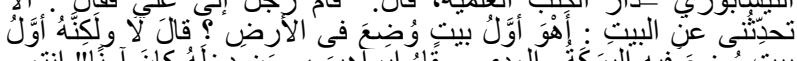

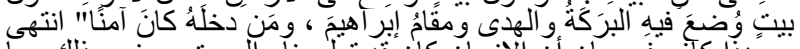

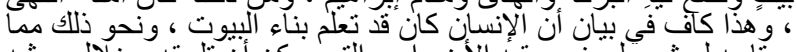

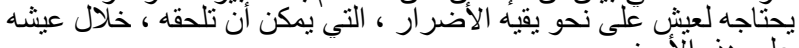


وتغرض عليهم العبودية، وبعد مدة تتحول الطبقية إلى واقع لا مفر منه، وقد استساغته البشرية لأنها كانت السبيل للخلاص من القتل، وكان فرصة ليحصل المنتصر على المزيد من الخدمات لصالحه ما أضاف قوة إلى قوته، فزين الثيطان للبشرية بعدئذ السطو، والغزو، وسائر التصرفات التي من

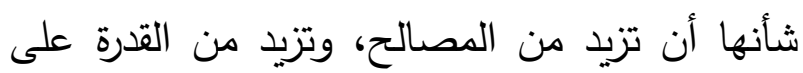

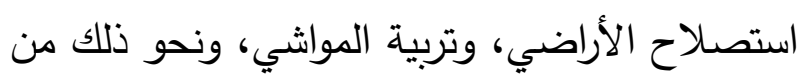
خلال الطبقة الجديدة من الأيدي العاملة (العبيد)،

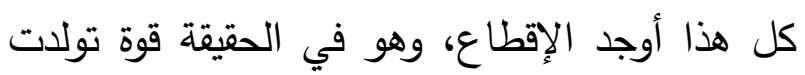
من توفر المال، والقوة، معا، وهي سمة الأقطاع ذلك ولك الزمن، لأن الرأسمالية الحالية في الحقيقة مالمان هي اقطاعات، ولكن بسلطة تمنحها الأموال التي بأيدهم لا بيد السلطة، فهم على الحقيقة يتحكمون بمصادر

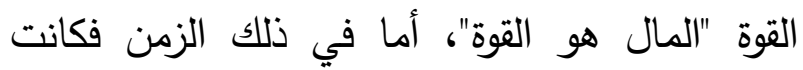

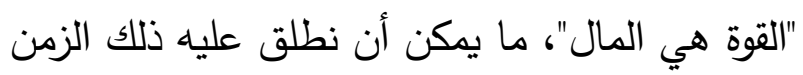

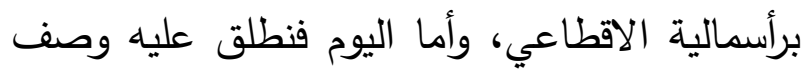

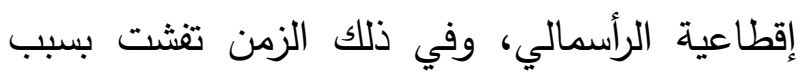

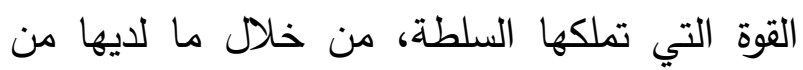
ثروات مرتبطة بالأرض وباقي عوامل الإنتاج، نعم

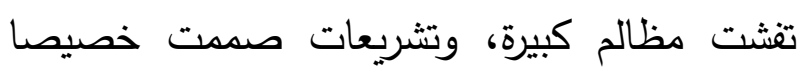

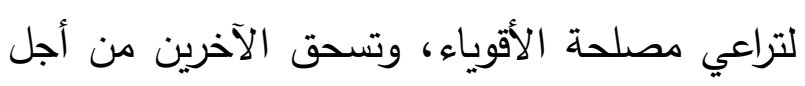

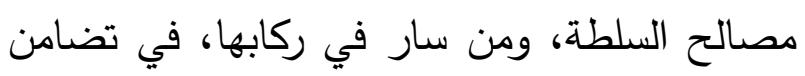
واضح بين أهل السيف، وأهل القلم، فوظف أهل

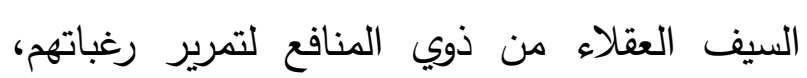

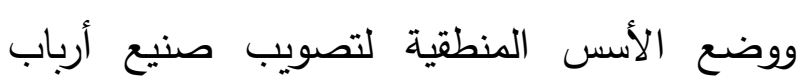

وكانت خيار الراغبين على الخروج عن سلطة القبيلة، لتقوم قبيلة جديدة، تتأسس على البداوة،

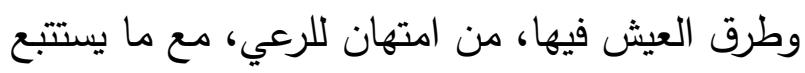

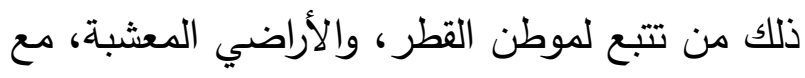

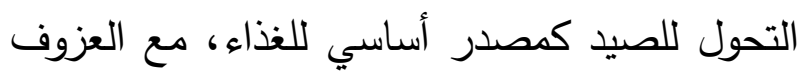

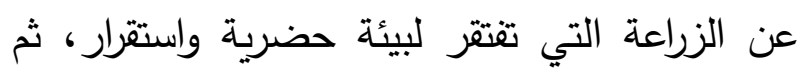

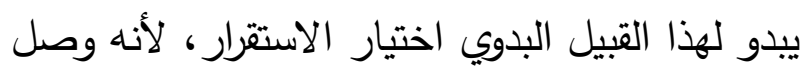

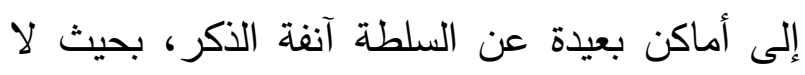

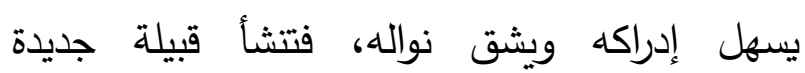

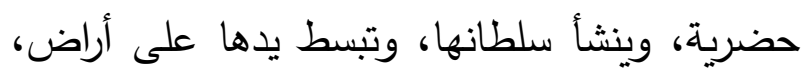

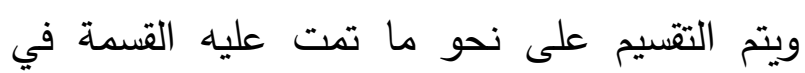
القبيلة الأولى، ثم يوجد خلاف فيخرج من يخرج

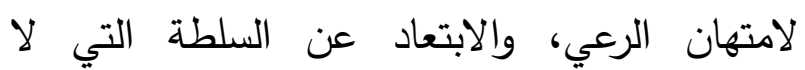
يرتضيها، ويصل إلى ديار لا يكاد يدركها القبيل

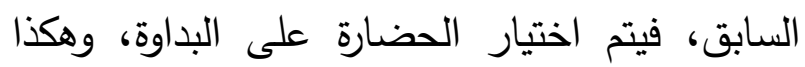
لتنشأ قبيلة جديدة، وتتكرر القصة، وينتشر الناس، ويبتعد بعضهم عن بعض بمسافات كبيرة، ولبيئات

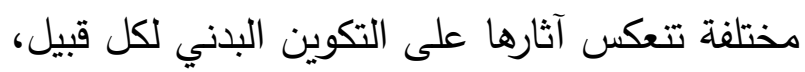

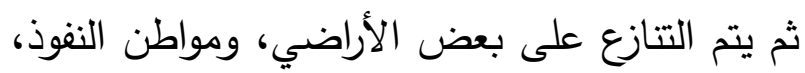

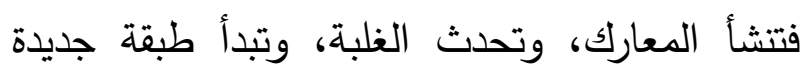

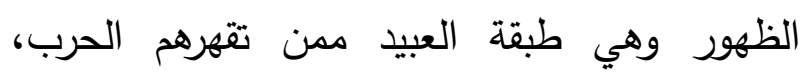

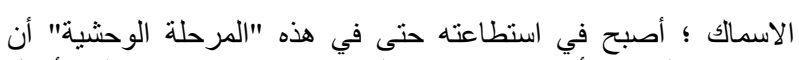

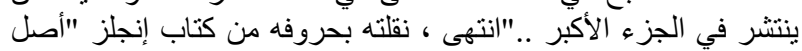

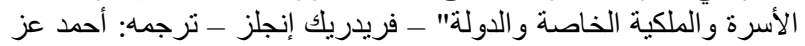

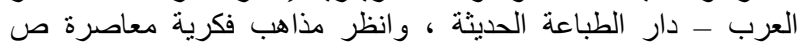

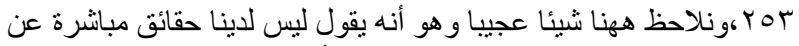

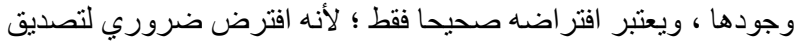

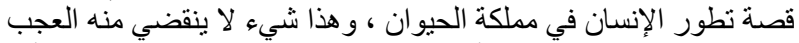

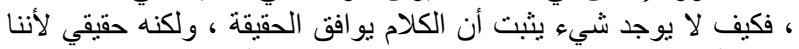

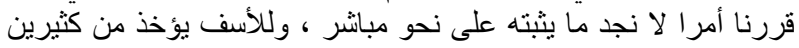

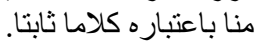


أَخَاذة(170) من الأرض، تهبها الدولة، أو السلطان،

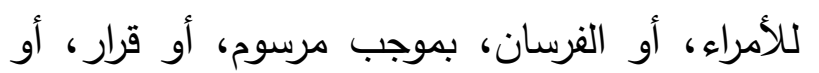

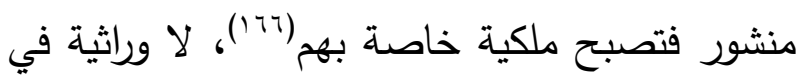

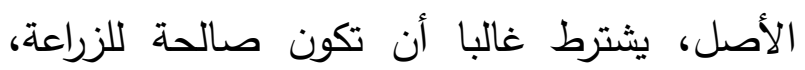

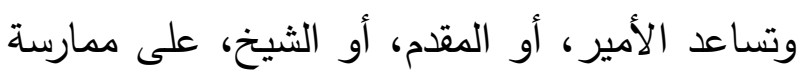

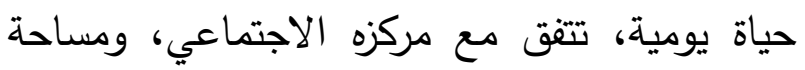

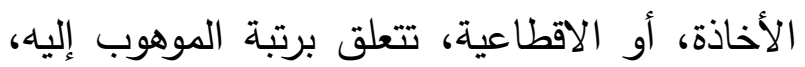

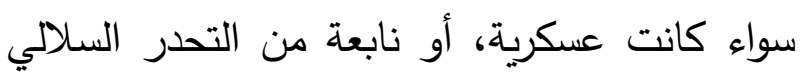

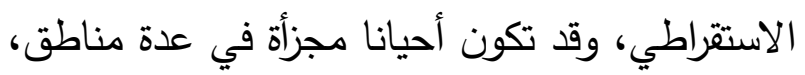

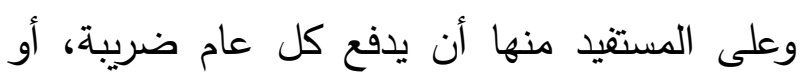

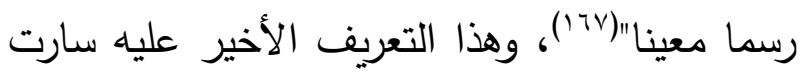
معظم التعاريف الغربية، غير أني لاحظت أن الن النير النيل معظمه يربطه بالقرون الوسطى، وتحديدا بالحالة الأوروبية، والحقيقة ليست كذلك ؛ لأن الإقطاع إفراز طبيعي ينتج استجابة لطبيعة بني البشر، وما تركب

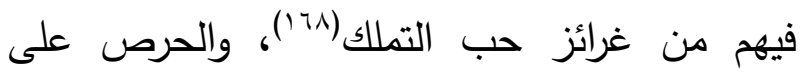
الثراء(791)، وامتلاك القوة، ومصنادرها النابع من شدة أنانيتهم (•lv)، وحرصهم على توسيع نطاق مصالحهم

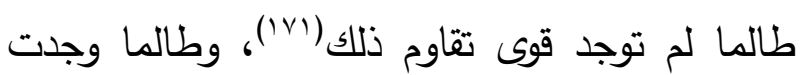

(170 (17 ) - أي جزء مأخوذ من الأرض.

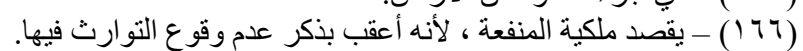

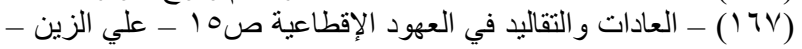

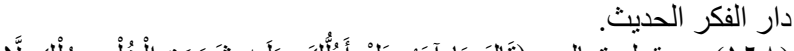

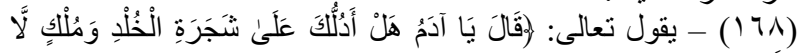

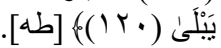

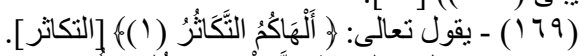

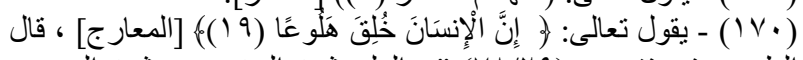

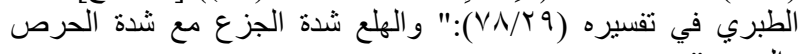
والضجر" (IVI)

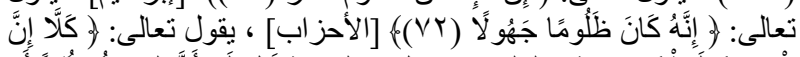

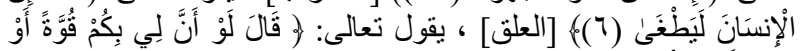

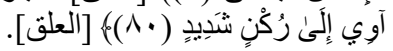

السيف، في تحالف لا يكاد ينجو منه صاحب قلم،

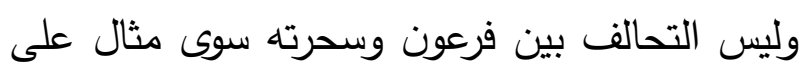

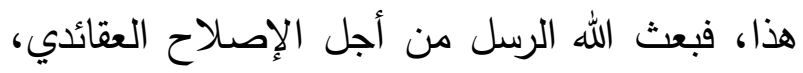

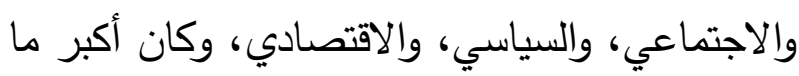

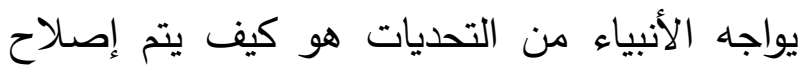
ذلك كله، فتنشأ الصراعات، وتحمل أنبياء الله العناء الكبير من أجل إعادة الإسلام ليكون النور والهداية

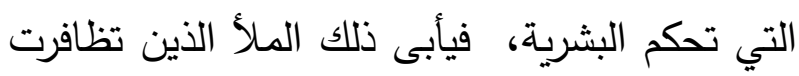

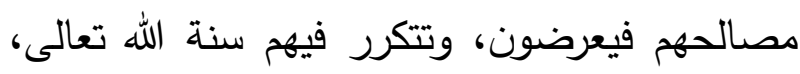

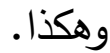
ما سبق يظهر لنا كيف نشأ الإقطاع ويوضح معناه

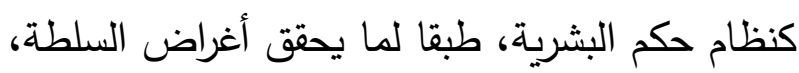

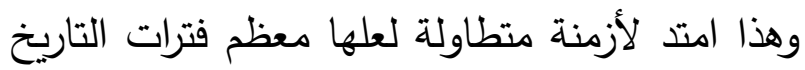
قبل العصر الحديث الذي لا يتجاوز عمره أربعمائة عام، ولهذا عرفته الموسوعة العربية بقولها:" الإقطاع: مصطلح عام، يستخدم لوصف النظام السياسي، والعسكري، الذي كان سائدا في غربي أوروبا، ففي ذلك العصر ، حيث لم تكن هناك حكومة مركزية قوية، كما كان الأمن ضعيفا، لكن النظام الإقطاعي، كان يسد الحاجة الأساسية، للعدالة،

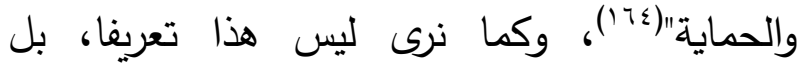
توصيف عام، لا يضيف معنى يميز الإقطاع، وهو تعريف عرفه الإقطاع بالمكان حيث حدد مكان

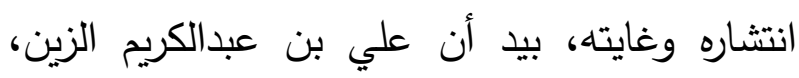
عرَّف الإقطاع على نحو وصفي دقيق فقال:" هو 
صحة ذلك القول ؛ خلو السور القرآنية جميعا، من أية إثارة إلى الإقطاع، أو التتظيم الإقطاعي من لهن

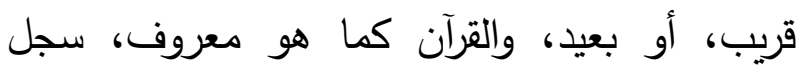

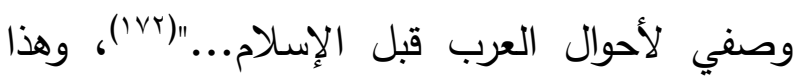
القول من المؤرخ محمد مصطفى، يسلط الضوء على لـ لإنى

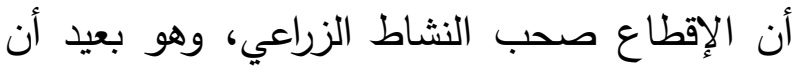
يفرض في بيئة تجارية، وهذا مما لا أتفق معه فيه؛ لأن الإقطاع وفق مفهومه، الذي ذكر آنفا، بمثابة حكم محلي، يصبح من حق المُقُْعَع استغلال المكان لهان

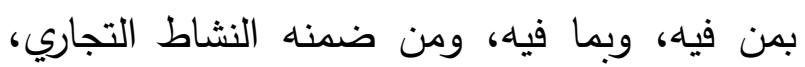
غير أني أتفق معه في الرأي، من جهة عدم انتشار

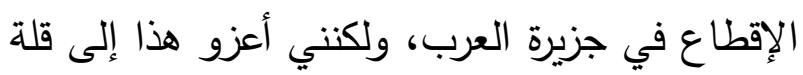
الخصوبة في الأراضي، ولو قلت قلة المياه لكان أدق، فبالكاد تحقق الأرض الكفاية لساكنيها بالنظر ولاهر

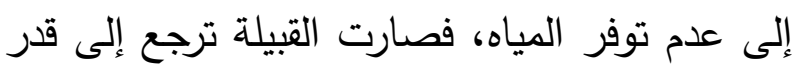

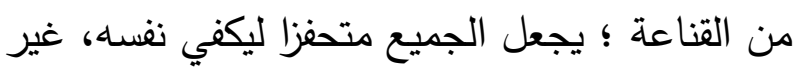

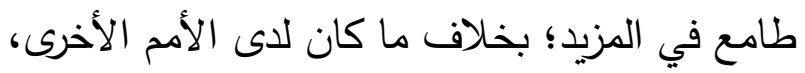

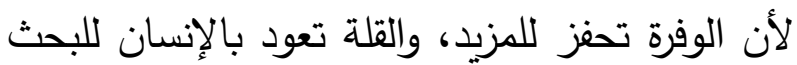
عن الكفاية، فتصبح القناعة رفيقة ذوي القلة، والطمع رفيق ذوي الوفرة، ولهذا وجد الإقطاع في البيئة العربية، ولكنه ليس يختلف عن معناه في الفقه

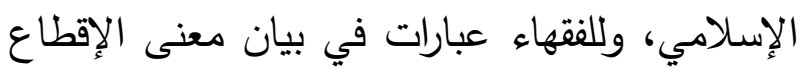

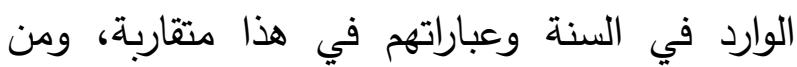
أجمعها ما قاله القاضي عياض:" الإقطاع: تسويخ

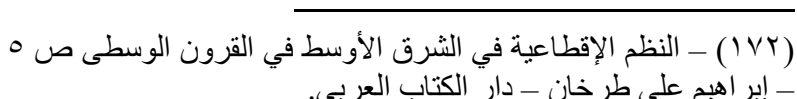

وسائل لتقاسم السلطة والنفوذ، وهي حالة تابعة لمدى خصوبة الأراضي، ومقدار المنافع المتحققة منها، بوصف الأرض أهم عامل في الإنتاج، ولهذا كان بسط السلطان على أكبر قطاع ممكن هو الغاية، وتحويله إلى إقطاعات تابعة لعناصر سبقت الإثارة إليها، أمر تقود إليه رغبة المجموع القبلي للحفاظ على أعظم قدر من الدصالح، واتساع النفوذ، دون الني منافس، وهذا لا يتأتى إلا وفق نظم اقطاعية تابعة للسلطة، وتبقى قوة الاستقلال في القبيلة، تابعة لقوة

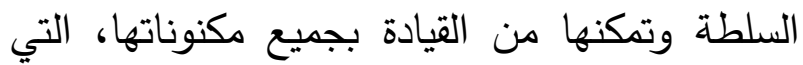
متى ضعفت، تهدد الاقطاع كله، ما يؤدي لتغير الولاءات تبعا لذلك، رغبة في الحفاظ على المصالح

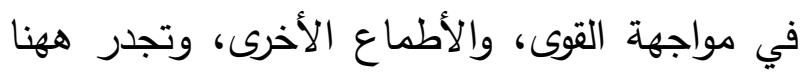

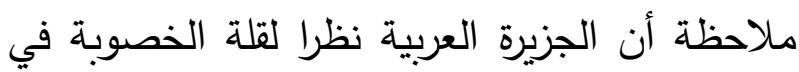

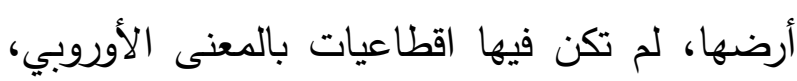
أو الشرقي أو تلك البلاد ذات الخصب، أو الأكثر الأبر

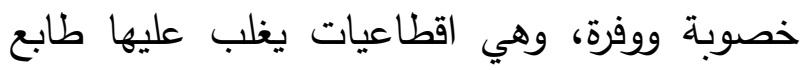
الإقطاع العسكري وفق التعريف آنف الذكر، وإنما وجدت اقطاعيات لدى العرب بمعنى تخصيص مواقع لا ملكية فيها لأحد، من أجل الاستغلال بطرق لأب الاستغلال الممكنة، ويقول محمد مصطفى زيادة:" نشأت الدولة الإسلامية الأولى، في شبه الجزيرة

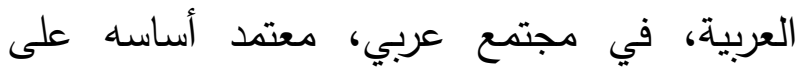
التجارة، لا على الزراعة، دون أن يستند ذلك المجتمع عيتع

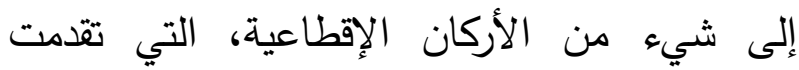

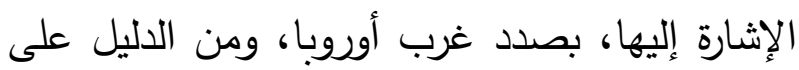


تبسط نفوذها في بقعة من الأرض، وتكون للمُقْطَع حقوق السيادة، والإدارة في تلك البقعة بما فيها، ومن فيها، وغاية المقطع تحقيق مصالحه الثخصية، بهامش يزيد على المصالح المتحققة لمن أقطعه، وشتان ما بين المفهومين.

والآن ما صلة الكلام آنف الذكر بموضوع الدراسة؟

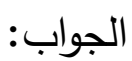

إن الصلة وثيقة ؛ ذلك أن الضريبة، إنما تفرض وفق أسس النظام الذي يحكم، فحين يسيطر الحكم الإقطاعي، تكون الضريبة محددة وفق ما تقرضه السلطة، مضافا إليه الهامش الذي يرغب المقطع اصطفاؤه لنفسه، وهذا بخلاف ما يمكن أن يتحقق من خلال الاستغلال المباشر للأرض، وهذا وفق معنى الإقطاع بمعناه غير الفقهي، فالنظم الإقطاعية نظم ضريبية بالضرورة، وللأسف هي نظم يغلب عليها جانب المنافع الشخصية، وفيما يظهر هي المقصودة بالمنع الثرعي عن الضريبة. وأما بالمعنى الفقهي فلا توجد ضريبة، يتم فرضها على المقطع أصلا، وغاية الإقطاع هي توسيع القاعدة الاقتصادية، ما له أكبر الأثر في التشغيل العام، وفتح منافذ للعمل، وتشغيل الأيدي العاملة، مع زيادة في حصيلة الفرائض الثرعية من زكاة ونحوها، باعتبارها فرائض شرعية لا ضرائب، لأن المقطع لا يلزم بأية مبالغ لقاء الإقطاع(IVT).

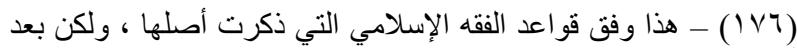

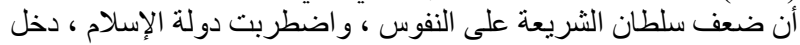

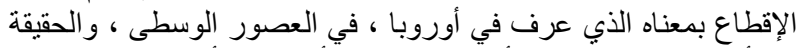
هي أنه عرف في المشرق أيضنا، و غيره ، و وأكبر دليل أن النظام الإقطاعي
الإمام من مال الله شيئا لمن يراه أهلا لذلك"(Yrr)، قال في الروض المربع:" وللإمام إقطاع موات لمن يحيييه لأنه بالإقطاع، بل هو أحق من غيره، فإذا أحياه ملكه، بله وللإمام أيضا إقطاع غير موات تمليكا، وانتفاعا للمصلحة ... مالم يضر بالناس ؛ لأنه ليس للإمام

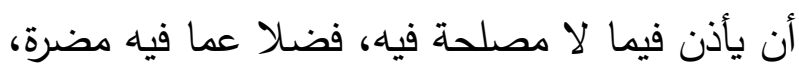

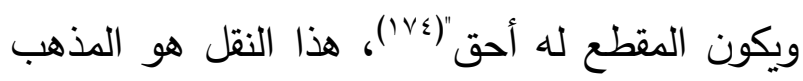
عند الحنابلة، وهو كذلك في المذاهب الأربعة(1V0)؛ ونلاحظ ههنا أن للأقطاع معنى في الفقه الإسلامي بخلاف الإقطاع الذي عرف عند غير ان المسلماعلمين،

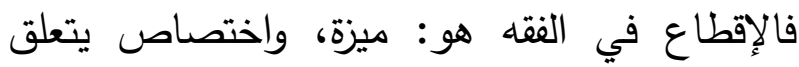

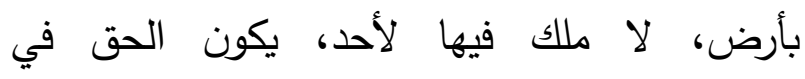

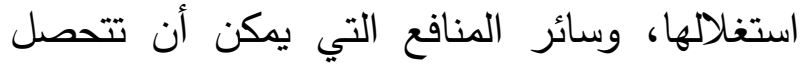

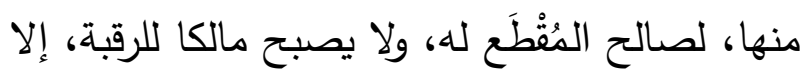
وفق مصادر حق ملك الرقبة لسائر الناس، وهو الإحياء في هذا المثال، غير أن له أولوية على أنى

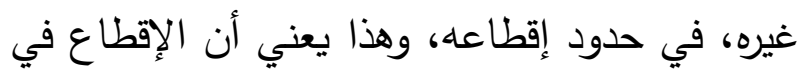

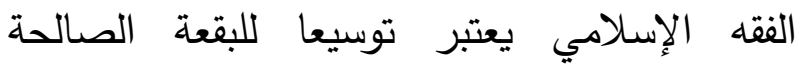

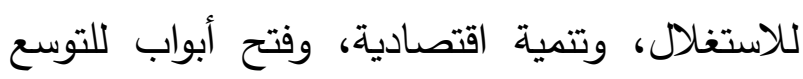
من القادرين عليه، وفرص جديدة للعمل، وأما الإقطاع الآخر، فهو أقطاع عسكري، أو قل بمعنى أوسع هو تأمير، ومنح الحق في الإدارة، وولاية الأحكا،

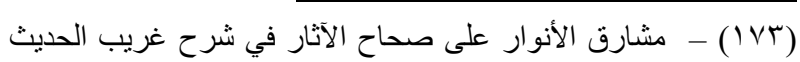
إل

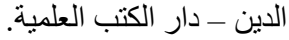

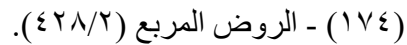

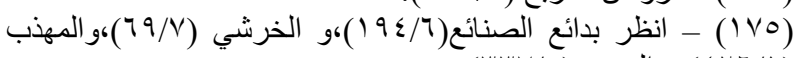
(rTV/O) ( 
تكون مصدر رزقهم، غير أنهم اختاروا الهجرة على البقاء تحت السلطة السابقة، وهذا يجعلهم يمتهنون أعمالا تخدم أصحاب الأراضي والجنود، والسلطات المحلية، تخرج عن إطار اهتمام أصحاب الأرض، وفرسان المدينة، بخلاف ما تسفر عنه الحروب من نتائج، تشرد وبعد عن الوطن، أو خسارة للأراضي لمصلحة الغزاة، ووجود طبقة كبيرة من العبيد، الذين ليس لهم ملكيات خاصة، هذا كله أدى لنشأة حركة سوقية كبيرة، تتعلق بمهن كثيرة، وتنوعت وتعددت على نحو أوجد قوة للسوق، وبعد مدد طويلة - نحن نتحدث عن عدة قرون - نشطت الأسواق والمهن، وصحب ذلك توفر للوسائط النقدية(YVY)، واهتمام بها، لهون

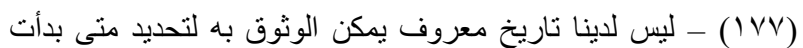

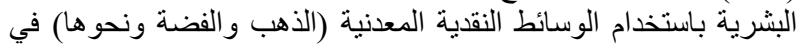

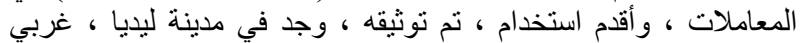

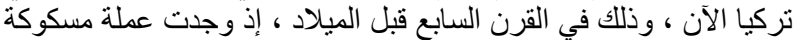

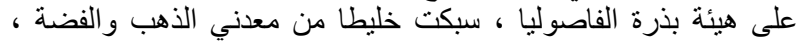

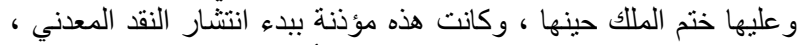

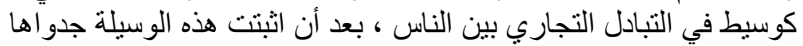

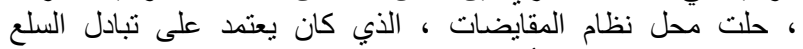

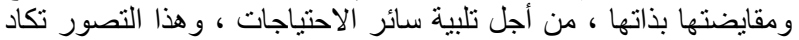
تجمع عليه الدراسات المتخصصة بثائن النقد ، قال آدم سميث في في كتابه

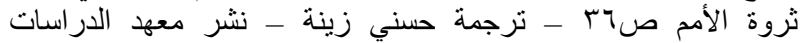

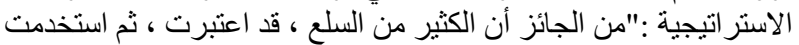

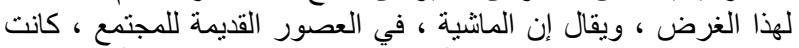

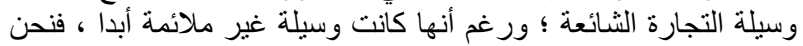

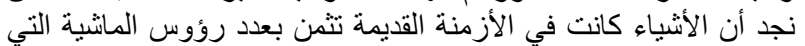

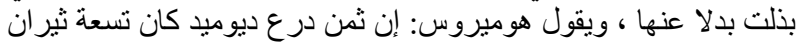

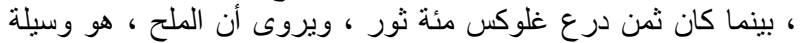

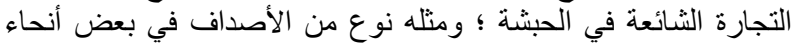

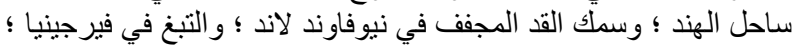

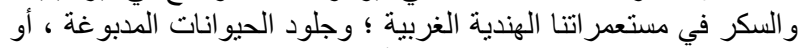

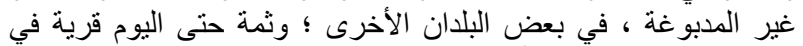

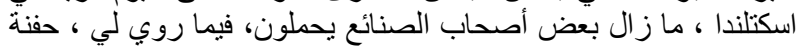

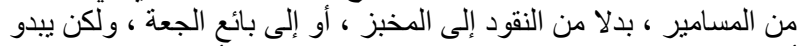

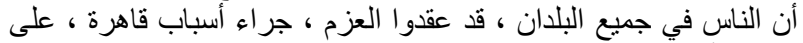

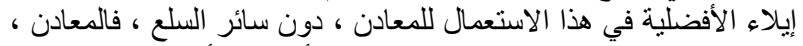

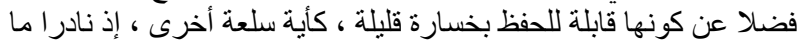

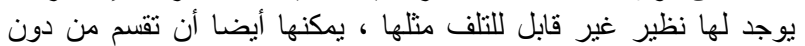
خسارة إلى أي عدد من الأجزاء ، كما يمكن لهذه الأجز اء ، أن أنتحد عبر دئ
ثانيا: النظام الرأسمالي. النظام الإقطاعي نظام تعتمد بنيته على الزراعة،

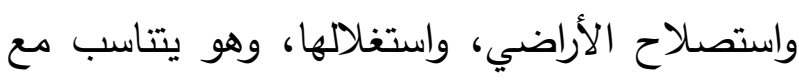

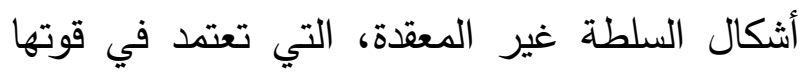
على توفير القوت الذي تؤمنه الأرض والمواشي،

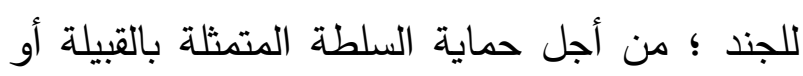

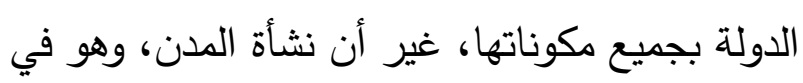
الحقيقة تحول القرية لتصبح مدينة، ذلك أن توسع

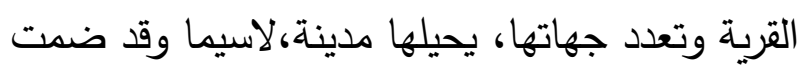

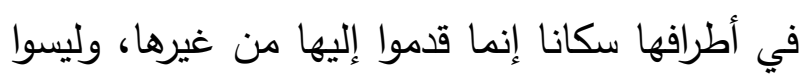
من أصحاب الأراض فيها، وإنما كانوا من أصحاب إنماب إنهاب

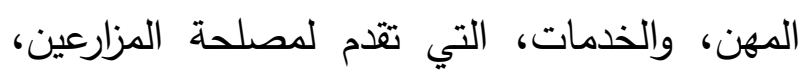

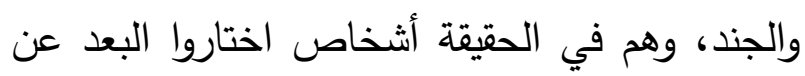

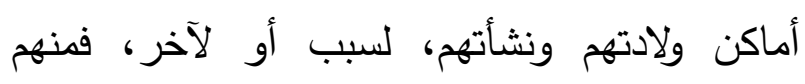

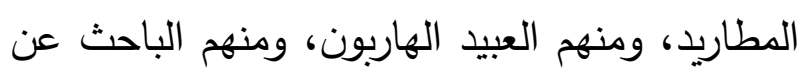
الرزق، ونحو ذلك، تاركين أرضا كان من الممكن أن الن النئ

الذي انتثر في العالم الإسلامي في العصور الوسطى ، إنما جاء بنأثر

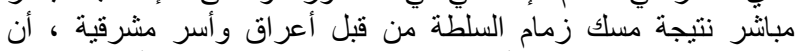

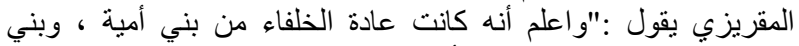

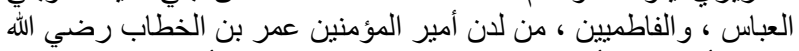

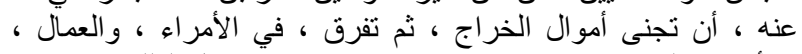

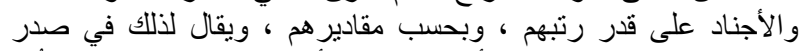

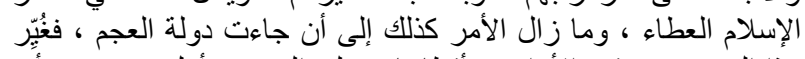

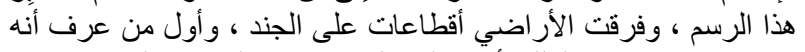

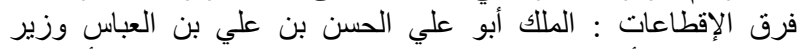

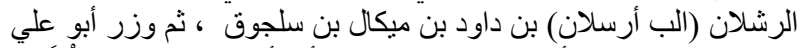

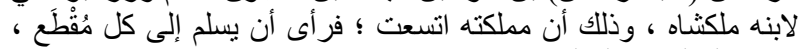

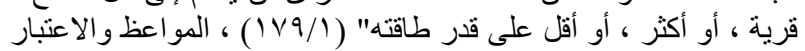

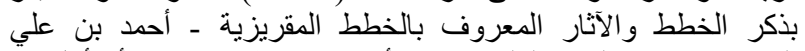

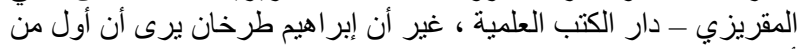

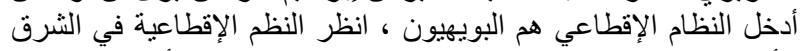

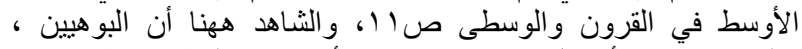

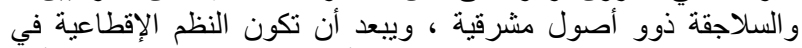

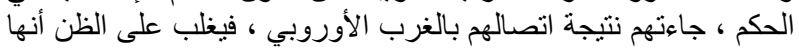

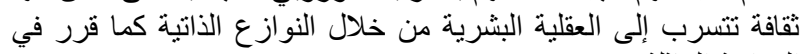

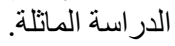


والسعي للبحث عن مناجمها، وقيام خدمات تتعلق

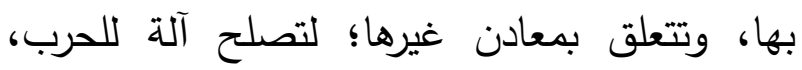
وغير الحرب، كل ذلك مهذ لوجود ثروة بعيدا عن بهن الأرض؛ لأن أبسط مفهوم للرأسمالية هو أنها :"تعبير اقتصادي للثروة، التي تستغل؛ لتتميتها، وزيادتها،

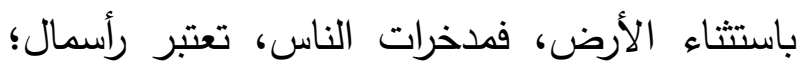

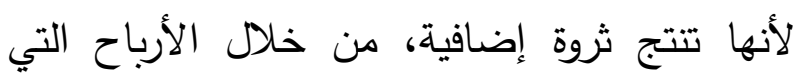

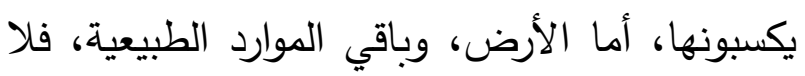

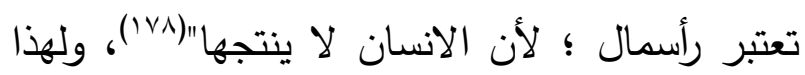

المقبول عقلا أو يمنح لزوجه ، و وأن يكون كذلك لبنيه المباشرين من صلبه ولثيه

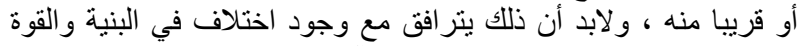

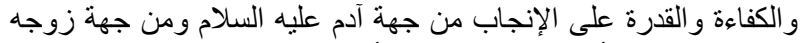

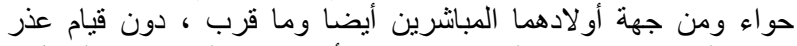

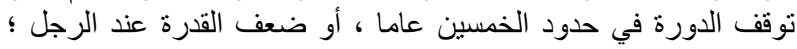

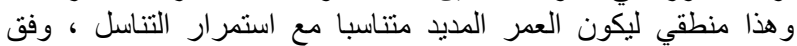
خصيصة عاثنتها البشرية ، تتناسب مع الزمن الذئي بدأت به البشرية

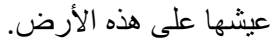

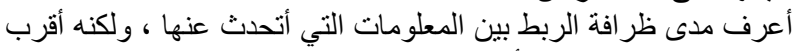

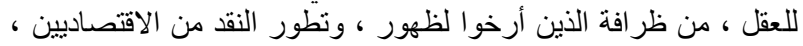

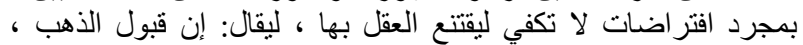

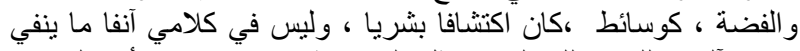

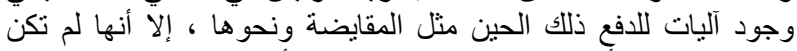

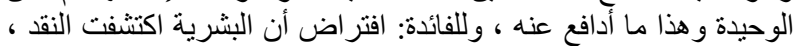

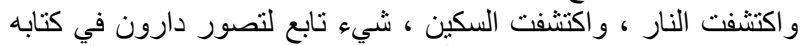

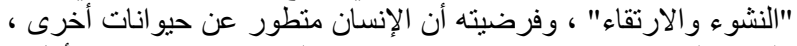

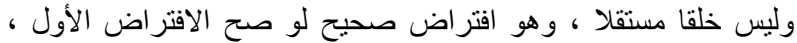

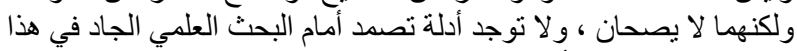

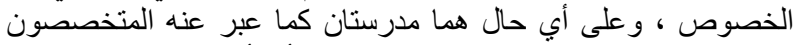

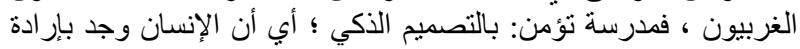

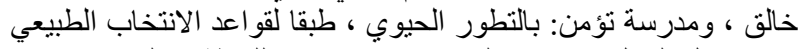

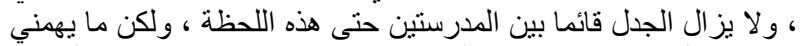

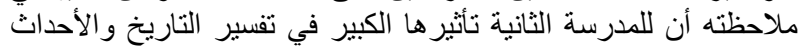

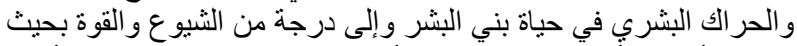

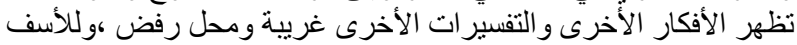

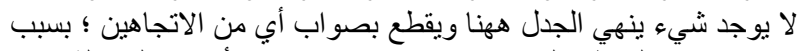

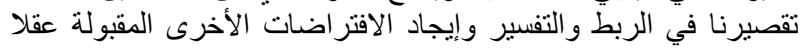

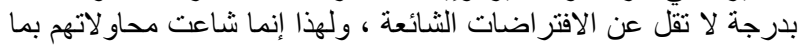

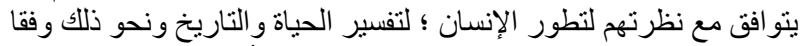

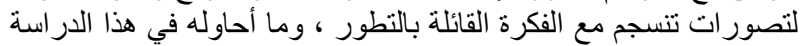

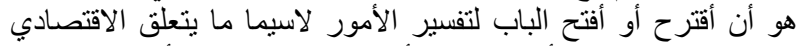

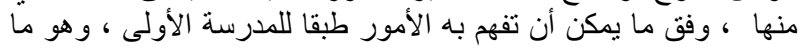

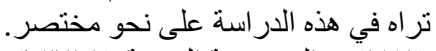

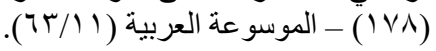

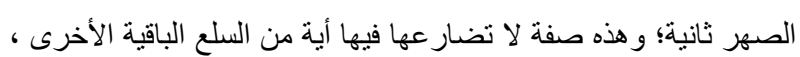

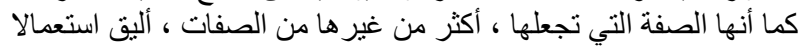

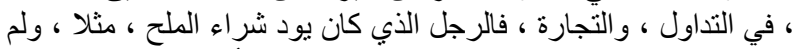

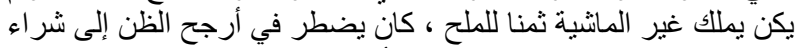

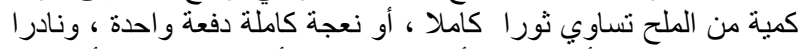

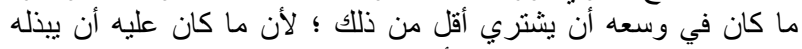

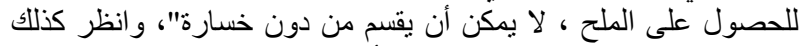

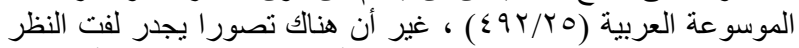

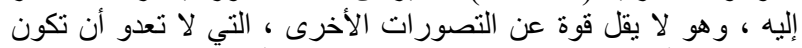

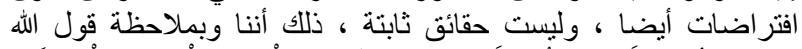

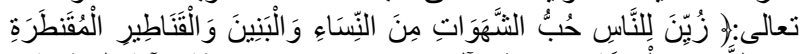

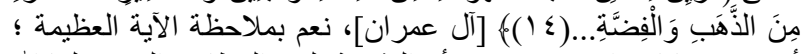

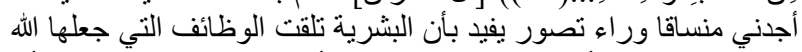

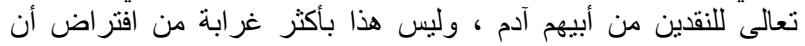

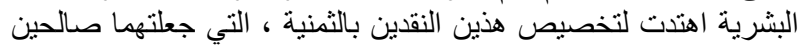

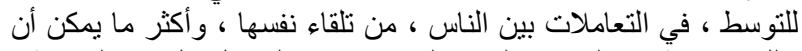

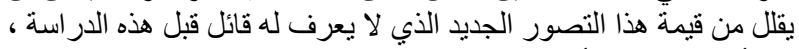

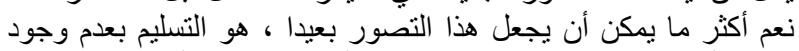

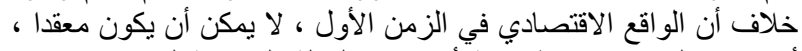

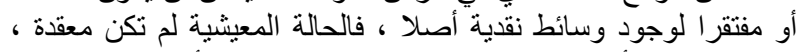

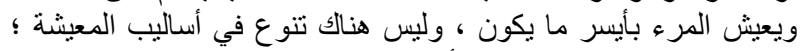

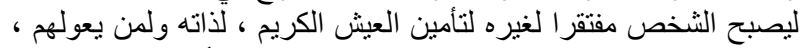

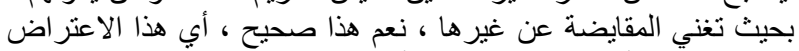

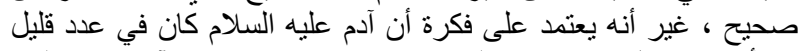

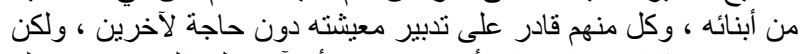

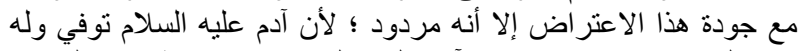

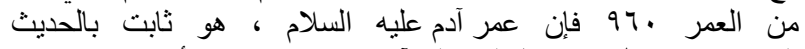

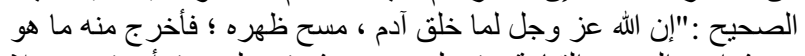

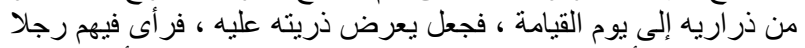

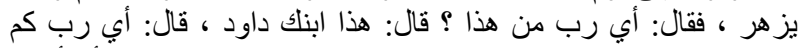

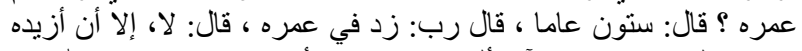

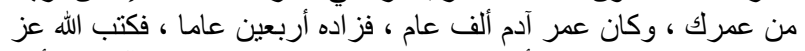

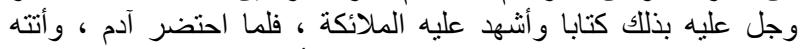

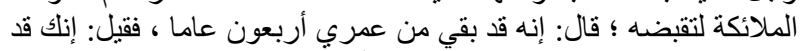

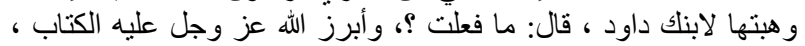

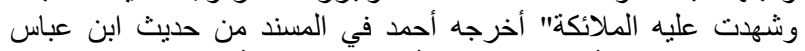

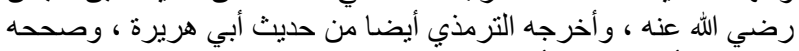

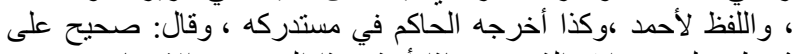

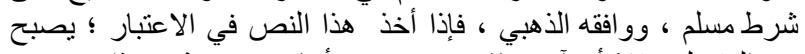

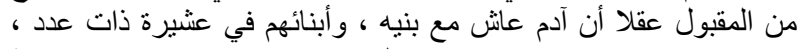

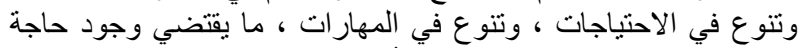

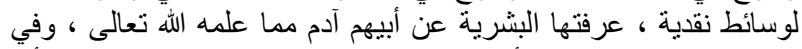

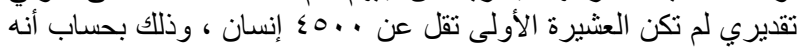

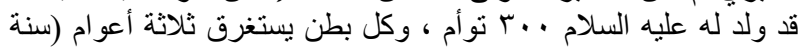

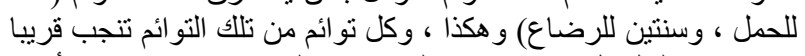

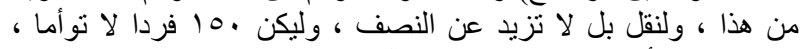

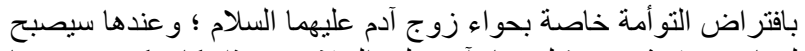

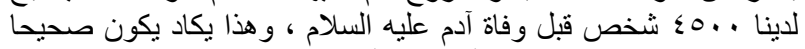

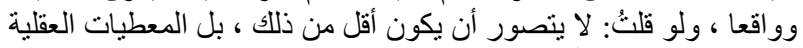

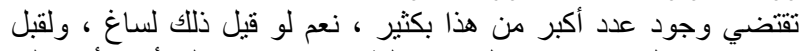

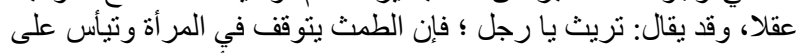

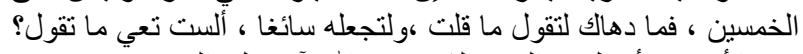

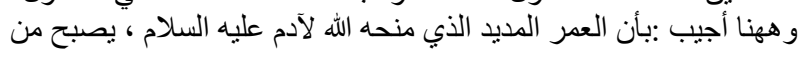


الله تعالى - إلى الأرض التي يعمل فيها، ولهذا

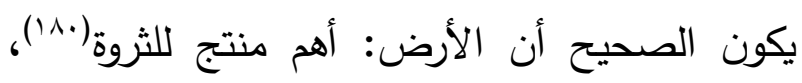

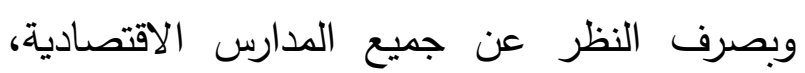

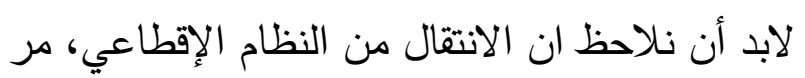

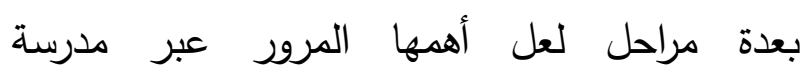
الطبيعيين هذه، فهي المدرسة التي نادت من أجل

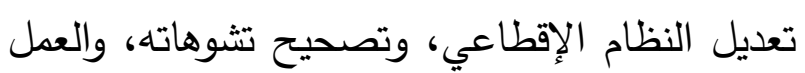

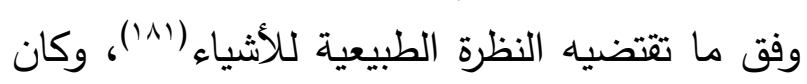

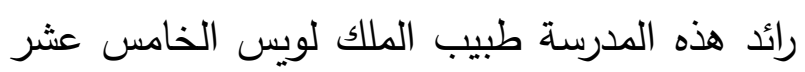

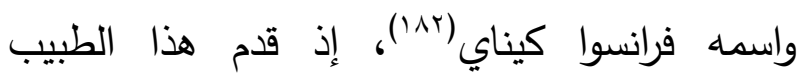

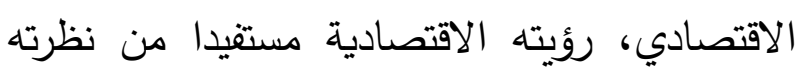
إلى طبيعة الإنسان الجسدية، فثبه الاقتصاد بالدورة الإنها الاموية، فما يخرج من القلب (الأرض) يعود إليها، بعد أن يغذي سائر مكونات الجسد (الدولة)، وأي لأي إعاقة للتدفيق؛ تصيب الجسد بالتجلط، فكلما تركنا

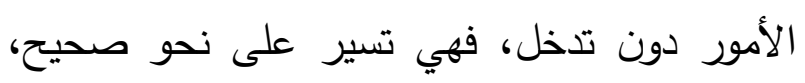

(1^•) - انظر الاقتصاد الوضعي والاقتصاد الإسلامي نظرة ناريخية

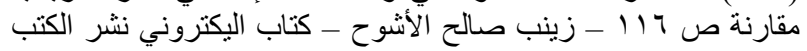

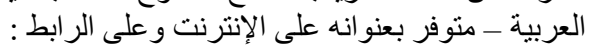
https://www.mobt3ath.com/uplode/book/book15817.pdf

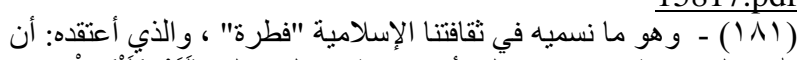

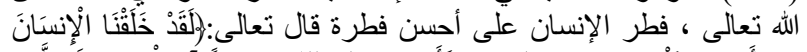

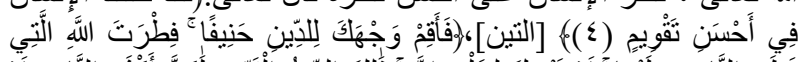

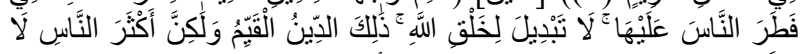

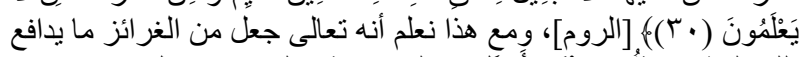

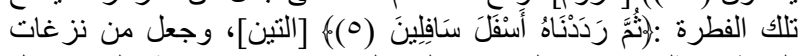

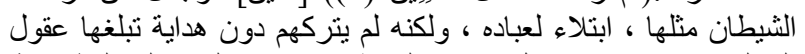

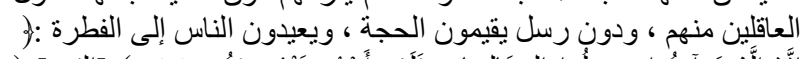

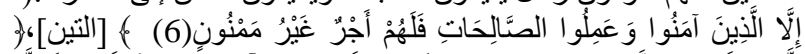

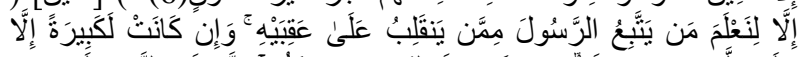

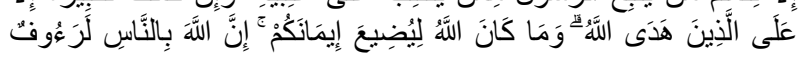

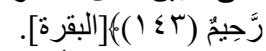

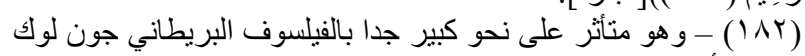
، كما سأثنير لاحقا .
جاء تعريفهم للرأسمالية على أنها :"النظام السياسي

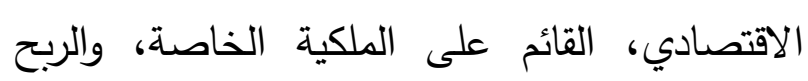

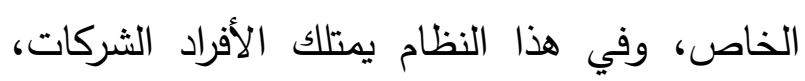
ويديرون أغلب الموارد المستخدمة في إنتاج السلع

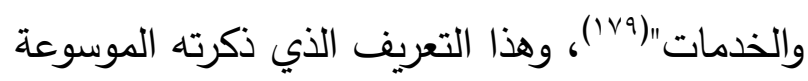

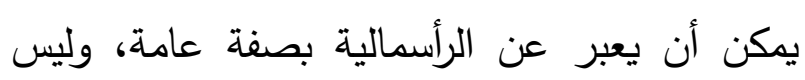

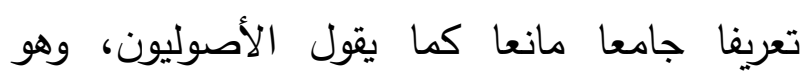

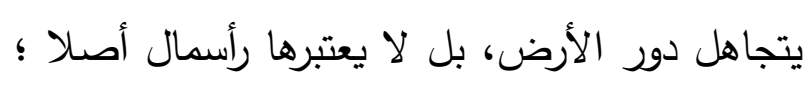

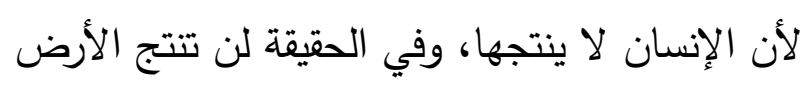

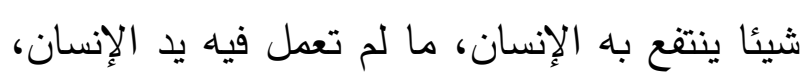
فما يحتطبه المرو - وهو أبسط مثال لاستغلاد

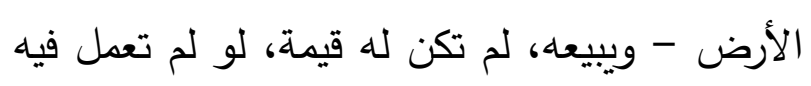

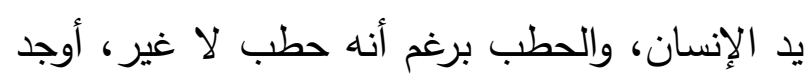

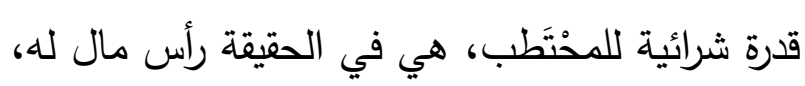

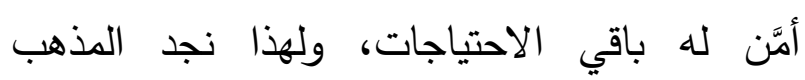

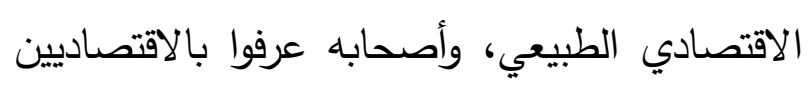
الطبيعيين: يرون أن الأرض هي المصدر الوحيد

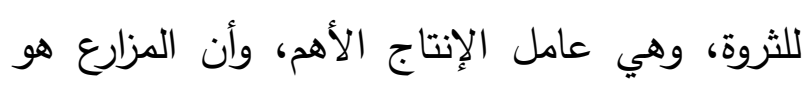

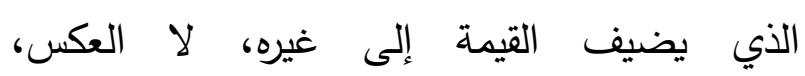
فالصناعي، أو مُلَّلك الأراضي، ينتجون، ويستهلكون

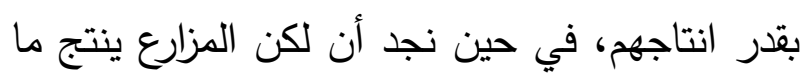

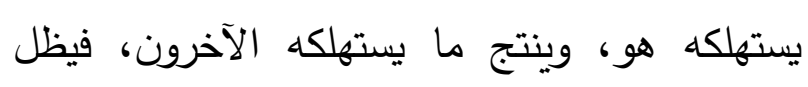

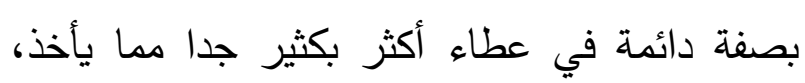
وفي الواقع لا يعود إليه بقدر ما أعطى أبدا، والميزان

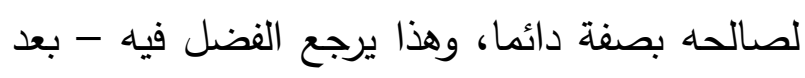


- التي كانت متحالفة مع طبقة العمال، في مواجهة أرباب الإقطاع، والسلطات الداعمة له، وهدفهم إحقاق مجموعة من الحقوق، والحريات المشروعة للطبقة العاملة، والمتوسطة، التي كانت تعاني من الظلم والاضطهاد، ما أدى في النهاية إلى أسقاط المَلَكِيَّة، وتأسيس الجمهورية، مع ما رافق ذلك من عنف، واضطراب أمني كبير جدا، بالإضافة للاضطراب السياسي، والفوضى العارمة، ما تحقق ليق لإن بسببه تغير كبير جدا في مسار التاريخ الحديث. وتجدر ملاحظة أن من أهم أسباب الثورة حينها؛ أن فئن كانت الحكومة الفرنسية غارقة في الديون، وحاولت استعادة وضعها المالي، من خلال خطط ضرائب، لم تحض بالقبول الشعبي، في الوقت الذي تم إنفاق الكثير من أجل دعم الانفصاليين في حرب استقلال في أمريكا، ضد بريطانيا، وامتد هذا الدعم فترة سبع سنوات، ليولد نظام ديمقراطي غير اقطاعي في أمريكا، بدعم نظام ملكي يعمل بآليات النظام الإقطاعي! تزامن هذا مع سنوات من القحط سبقت الثورة ؛ أثارت استياء شعبيا على الامتيازات التي

السادس عشر وأو ائل القرن السابع عشر ، ظهر موقف الطبقة البرجوازية

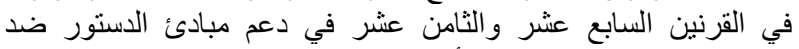

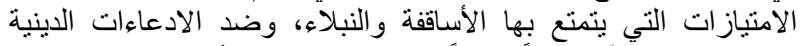

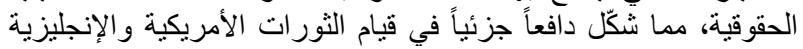

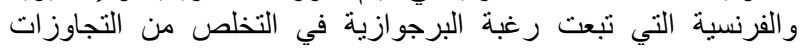

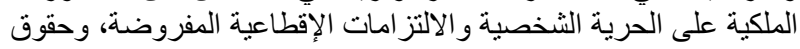

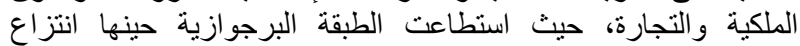

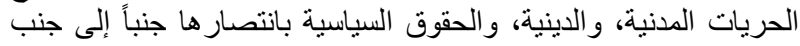

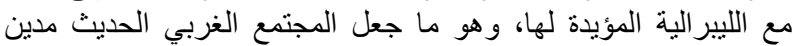

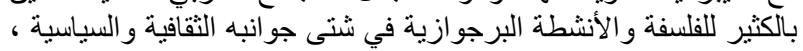

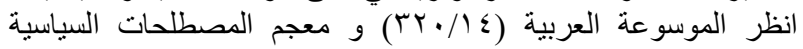
و الدبلوماسية والاقتصادية صو عـ - حسام الدين جاد الرب ــ ـ دار العلوم.
ولا يجوز لنا التدخل إلا حين يوجد تعثر، وعندها

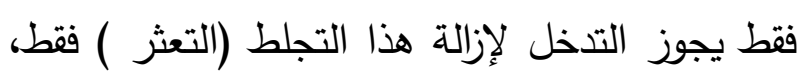

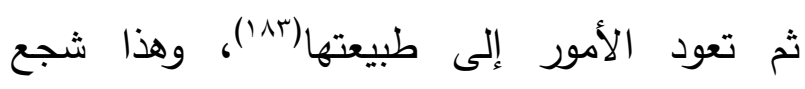
بالإضافة لكثير من الطروحات الفكرية سياسيا،

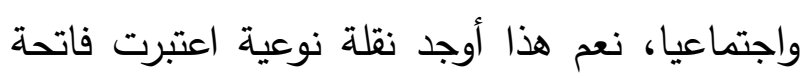

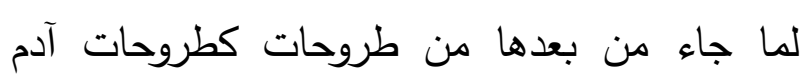

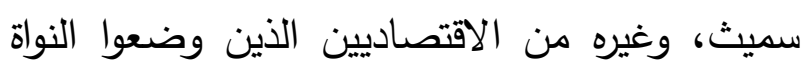

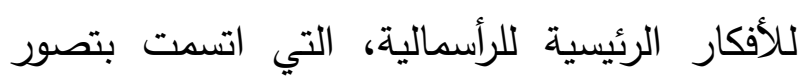

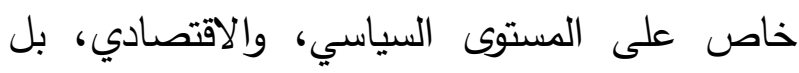
ويمتد تأثير ذلك إلى الاجتماعي، كل ذلك أدى لقيام

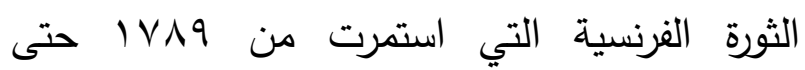

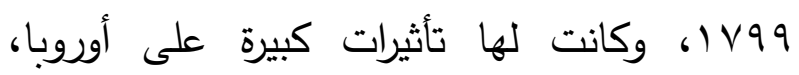

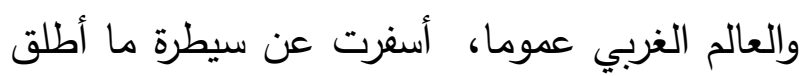

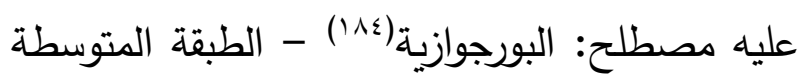

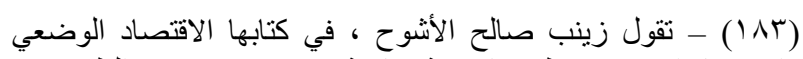

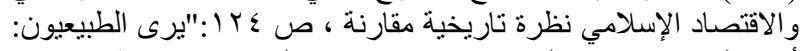

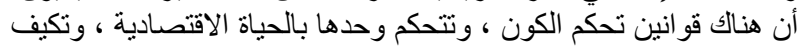

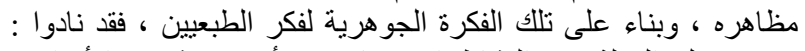

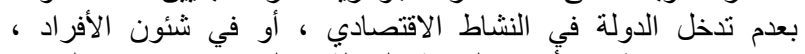

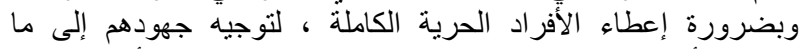

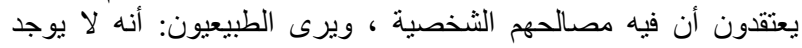

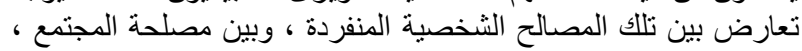

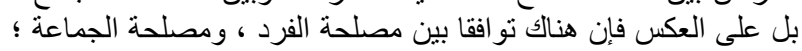

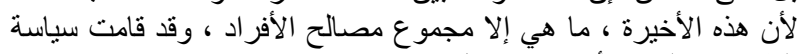

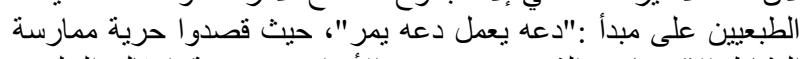

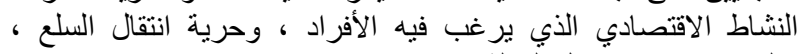

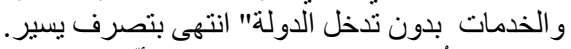

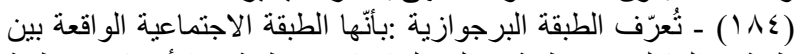

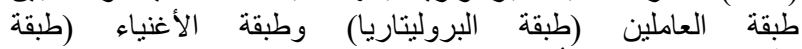

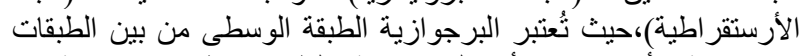

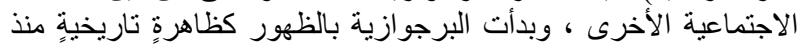

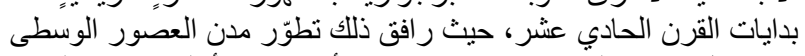

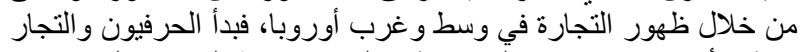

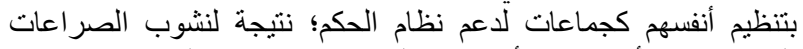

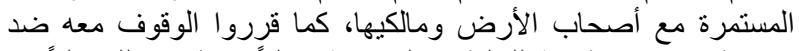

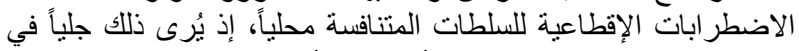

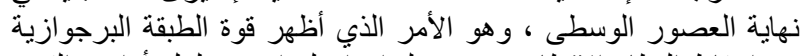

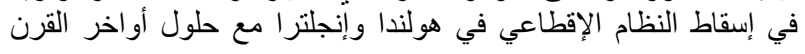


عموما، الذي وجد في فرنسا بفعل الثورة، ووجد في

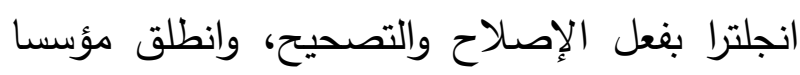
مدارسه عبر العالم، وهو في الحقيقة نواة تولد منها الفكر الاشتراكي، والثيوعي، كرد فعل لما أسفر عنه ونه

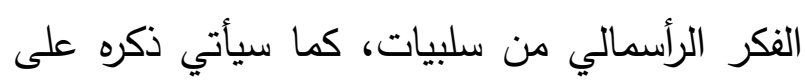

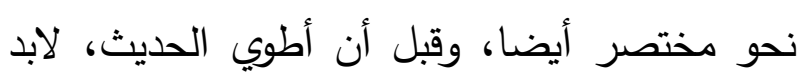

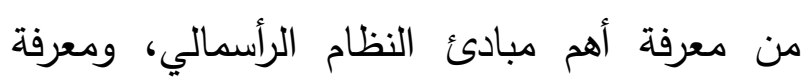
علاقته بالضرببة. الحياة الاقتصادية تخضع لنظام طبيعي، ليس من

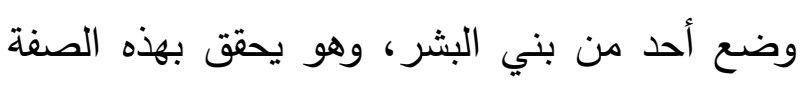

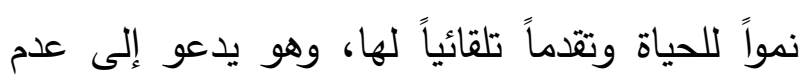

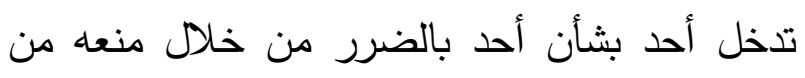

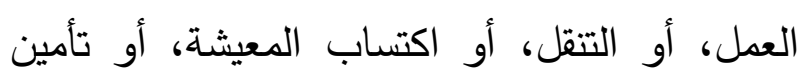

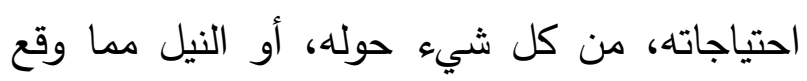

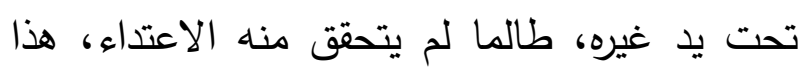
هو الأصل، وهو الطبيعي أيضا، وليس هذا قاصرا

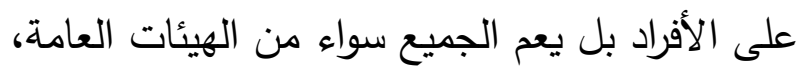

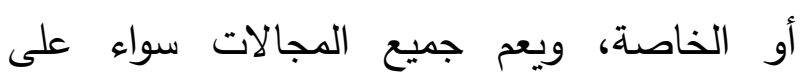

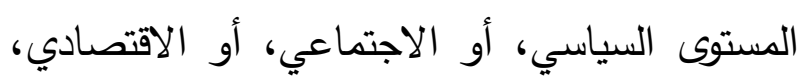

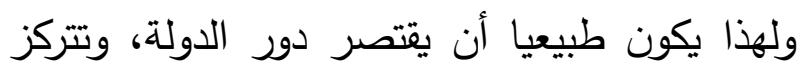

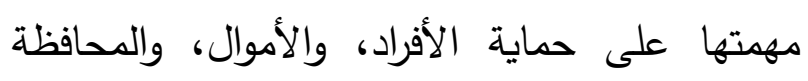
على الأمن، والدفاع عن البلاد، ولهذا أسفرت الثورة الثاني

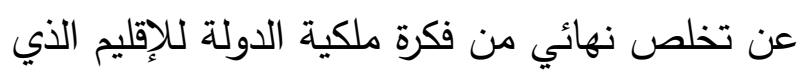
يدخل تحت سلطتها؛ وهي نتيجة طبيعية ظهرت

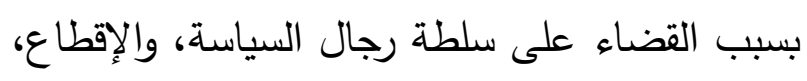
ووجود نواب يختارهم الشعب ليمثلونه، فالدولة "كيان"
يتمتع بها رجال الدين، والطبقة الأرستقراطية ؛ ما

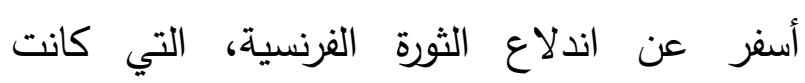

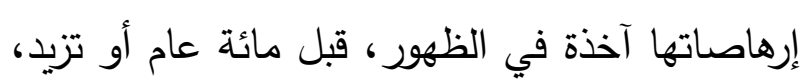
منذ نشرت أعمال لجون لوك عام (1017 امد) حيال أفكاره عن العقد الاجتماعي(1/0)، كل ذلك أدى إلى إلى إنى

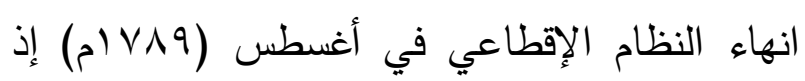

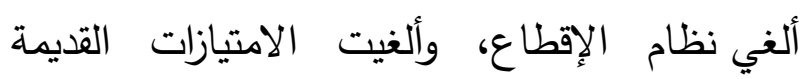
لصالح الكنيسة، بل وصل الأمر بعد سنوات تحديدا

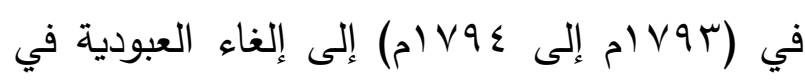

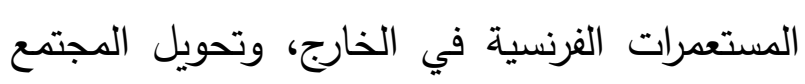
عن المسيحية من خلال إنثاء تقويم جديد، وطرد الثخصيات الدينية، وكان هذا في ظل موجة هائلة من الاضطرابات، إلى أن جاء نابليون بونابارت في

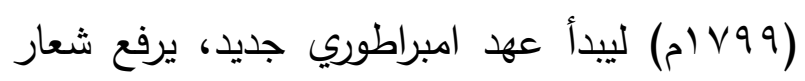
الحرية، والمساواة، والإخاء، وهو لم يمثل في الحقيقة

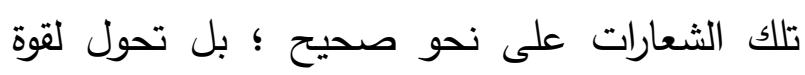

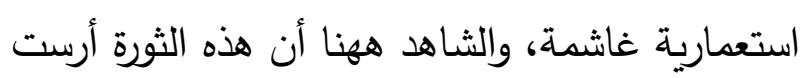
قواعد الفكر الرأسمالي في العالم الأوروبي، والغربي هذهي

(1/10) - جون لوك (فيلسوف بريطاني) أثرت فلسفته في الدفاهيم التي إني

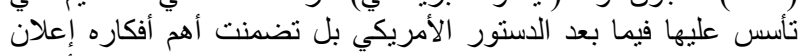

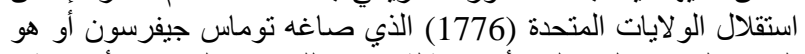

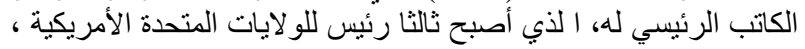

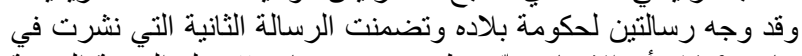

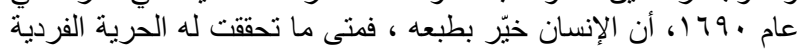

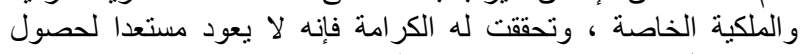

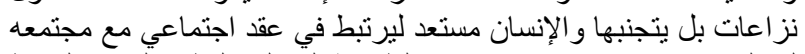

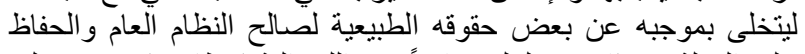

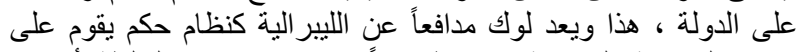

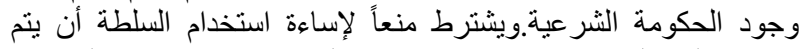

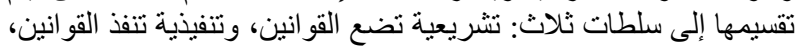

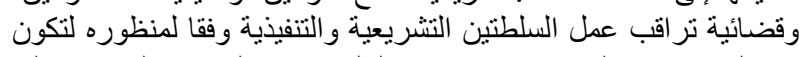

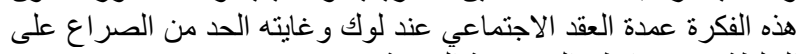

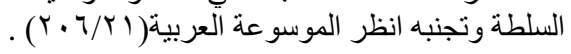


البشر ؛ فسعي كل فرد لجني المنافع يحقق المنافع

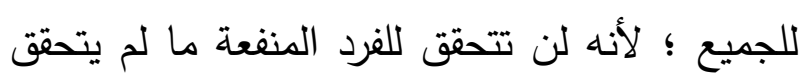
مثلها أو قريبا منها لجهة فرد آخر، وهذا يجعل الجميع منتقعا من الحرية التي أتيحت للجميع، فالتجارة، والصناعة، والزراعة، وكل مكون اقتصادي متى عملت في إطار من الحرية بحيث يتم الإنتاج، والتداول، والتوزيـع في جو من المنافسة الحرة، يحقق ذلك بالضرورة المنفعة، والتوازن الاقتصادي للجميع، وهذه الآلية بات يطلق عليه اسم "اقتصاد السوق"، الذي يعتمد على فكرة، أو نظرية اليد الخفية، وملخصها: أنك متى تركت لكل منتج حرية الإنتاج، وتركت لكل مستهلك حرية الاستهلاك ؛ فستكون النتيجة وجود سلع ذات نوعية جيدة، وبسعر منافس لتسود في السوق، مما يعود بالنفع على سائر أفراد

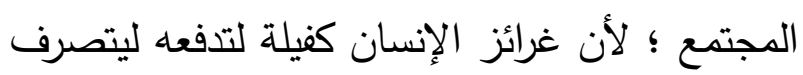
على نحو نافع، ما يؤدي إلى تحسين، وكفاءة الإنتاج لزيادة العائد، لجهة المهنيين، والتجار، عن طريق تقليص التكاليف بالجودة المطلوبة، مع محاولة جادة لخفض الأسعار، حذرا من المنافسة، كما ستزيد الاستثمارات في الصناعات التي يزداد عليها الطلب

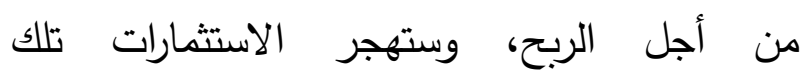
الصناعات الأقل ربحية، وهذا يشجع بالضرورة على التى تركيز الناشئة لدراسة التخصصات المطلوبة، أي التي ستجلب لهم مداخيل أعلى، وكل هذه التفاعلات تحصل بالدفع الذاتي دون تدخل من أحد، وهي ستحقق التوازن أيضا وتعيد التوزيع ؛ لأننا سنجد
يضم شعبا، وأرضا بحدود، وهذا الشعب ذ ذو سيادة(111) تمثلها حكومته التي تتصرف في نطاق الصلاحيات الممنوحة من الشعب، في ظل سلطات ثلاث، وهذا المكون يدير الدولة بصفته صاحب اختصاص، لا بصفته مالكا، وأما ملكية الأرض، أو ما هو عليها، فيخضع كل ذلك من بعد لمصادر الحق في التملك المعتادة طبقا للقانون(^v'). فتم تشريع الحرية الاقتصادية لكل فرد طبقا للقانون "الذي جعل الطبيعة من أهم مصادره" ؛ فغدى لكل امرئ الحق في ممارسة، واختيار العمل الذي يلائمه، وقد عبروا عن ذلك بالمبدأ المشهور :"دعه يعمل دعه يمر" ؛ لأن الحرية الفردية التي تتيح للإنسان حرية اختيار عمله الذي يتفق مع استعداداته، ويحقق له الدخل المطلوب، هي بالضرورة نافعة لكل بني

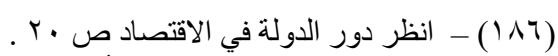
- ( IAV)

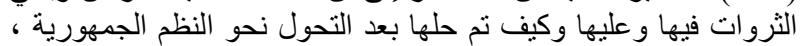

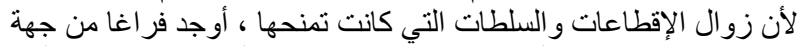

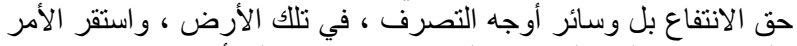

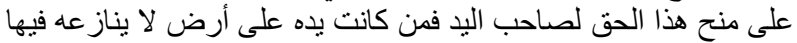

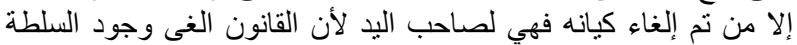

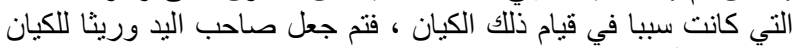

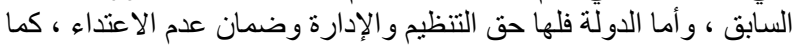

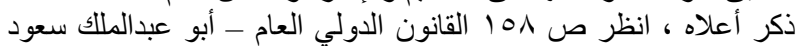

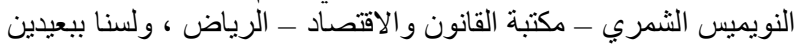

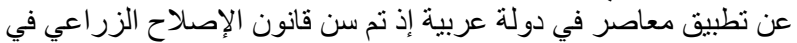

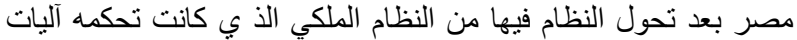

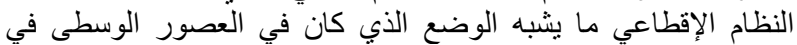

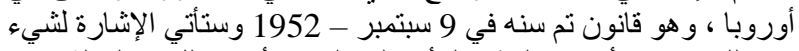

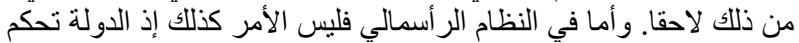

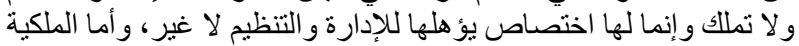

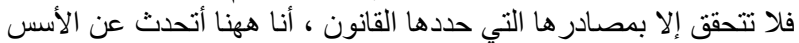

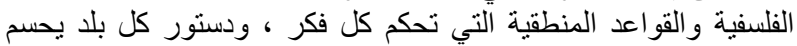

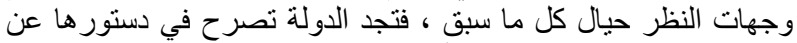

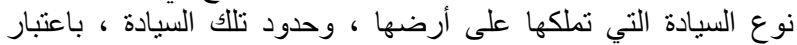
الدستور وثيقة قانونية عليا تنظم العلاقة بين السلطات الثرات الثلاث في داخل

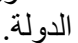


كتابه الإصلاح الاقتصادي :"التلوث الرهيب للبيئة

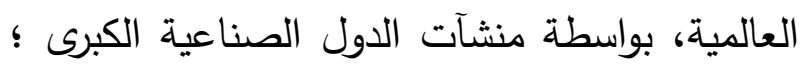
لهو خير دليل على قصور فلسفة اليد الخفية، وعقلانية الفرد"(·1)، هذا النقد مثله الكثير من قبيل إلقاء ما زاد من المحصولات الزراعية في البحر؛ خشية من نقص الأسعار، في الوقت الذي تنتشر المجاعة في كثير من بقاع العالم، هذا جعل معايير

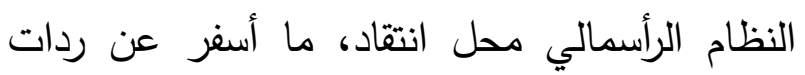
فعل مختلفة كان من نتائجها بزوغ الفكر الثيوعي، لرعال والاشتراكي، وسيأتي مزيد بيان لهذا. وهذا أوان الحديث عن صلة النظام الرأسمالي بما ونياتي مندان

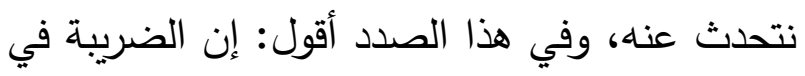
أصلها تدخل من السلطة في الاقتصاد، ومن خلالها تحصل الدولة على مبالغ دون مقابل. فهل هذا يقبل على مستوى الفكر الرأسمالي؟

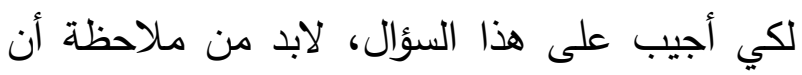
إلغاء الحكم الملكي والنظام الإقطاعي، تأسيسا على هلى لإنى الأفكار الليبرالية، وتتاغما مع قانون ما قبل القانون "قانون الطبيعة"، الذي نادى به جون لوك، وما قرره من بعده فرانسوا نيكاي، وغيرهما من مفكري الثورة لإنها

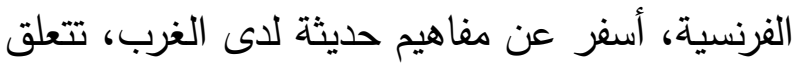
بالملكية العامة، لا سيما تلك الملكية التي تتعلق

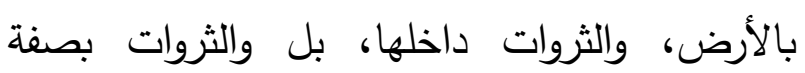
عامة، ولتأكيد هذا أذكر كلام حمزة البيلاوي قال

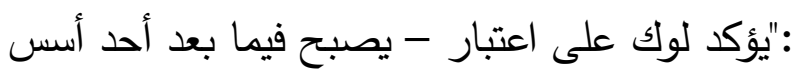

(19.) - الإصلاح الاقتصادي ص ؟11ا شريف دلاور - المكتبة

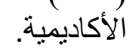

أفراد المجتمع الفقير مستعدين للعمل بأجور منخفضة ؛ مما يجذب المستثرين لإنثاء مصانع في المناطق الفقيرة ؛ لانخفاض تكلفة الإنتاج، وهذا يزيد الطلب على اليد العاملة في أوساطهه، ويشجعهم لبذل المزيد لإتقان العمل، ما يسفر عن مجتمع استهلاكي جديد؛

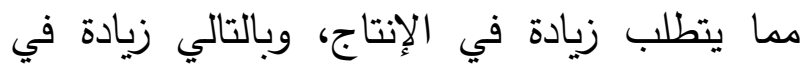
طلب اليد العاملة ؛ مما سيزيد من رواتبهم بسبب زيادة الطلب على خدماتهم، وستستمر هذه الحالة إلى تصبح كلفة الإنتاج في هذه المنطقة التي "كانت"

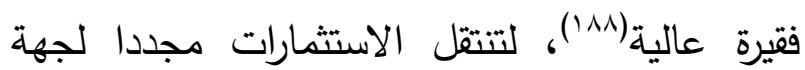

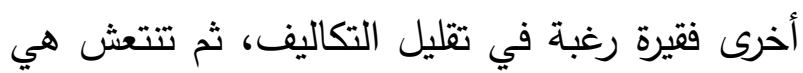
كما تحقق للمنطقة قبلها، وهكذا دواليك، هذا المفهوم هو الذي يطلقون عليه "|قتصاد السوق"، وهذا ليس حصرا بشأن الصناعات بل هو ينسجم مع التجارات أيضا وغيرها من الجوانب الاقتصادية(1) (1) . هذا وتم توجيه الكثير من الانتقادات للفكر الرأسمالي، وليس هذا البحث مخصصا لتتبع ذلك، ولكن يكفي أن أشير إلى وجود النزعة الفردية الطاغية، التي اتسمت بأنانية تتجاوز ما يمكن للعقل وجل التوديل تقبله، أو التسامح فيه، جعلت الفكر الرأسمالي يظهر على نحو غاية في القبح ؛ يقول شريف دلاور في لري

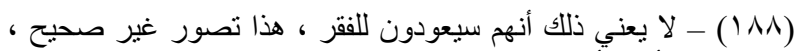

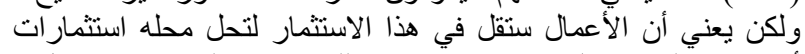

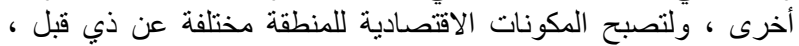

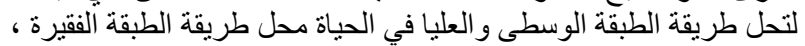

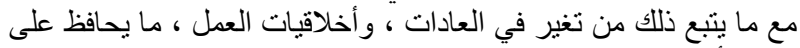

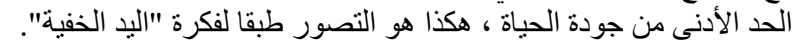

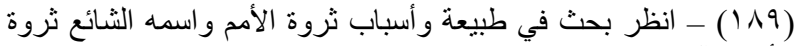

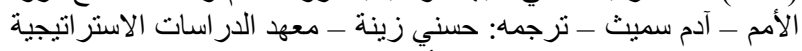

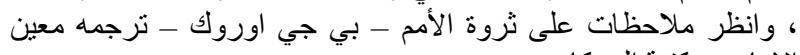

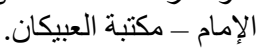


قواعده الثعبية، وهذا الكيان ليست لله ملكية خاصة، وإنما لله اختصاص يمنح بموجبه الحق في إدارة الإقليم(ب9/)، وهذا ينسجم مع التصور الصحيح للرأسمالية اليبرالية، ودستور كل بلد، وقوانينه الناظمة، تحدد معايير، وتطبيقات ذلك على أرض الواقع، والشاهد ههنا أن الدولة في النظام الرأسمالي حفظت حقوق الناس في الملكية الخاصة، ومنحتهم الحرية الكاملة في التصرف بممتلكاتهم، ولكن ألزمتهم المساهمة في نفقات الحكومة، بموجب القانون، وبقيت معضلة كبيرة تواجه السلطة الحاكمة في النظام الرأسمالي الليبرالي، وهي حدود التذخل الحكومي في الاقتصاد، وحدود الضريبة التي يمكن أن تفرض على الناس، في ظل قيام النظام أساسا على فكرة حفظ حقوق الأفراد، وحرياتهم إلى أبعد مدى، وتقليص دور السلطة في التدخل إلا في حدود الأمن والنظام العام، وهي أشياء تم تقريرها من قبل،

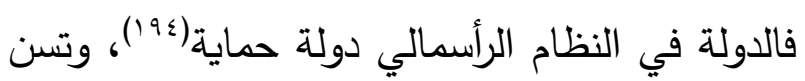

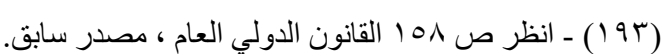

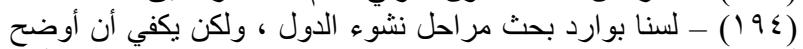

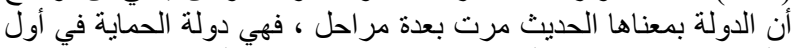

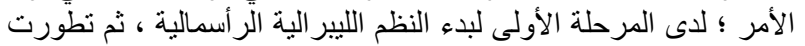

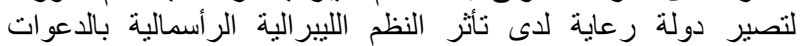

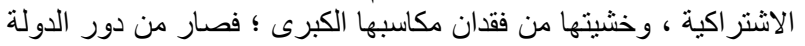

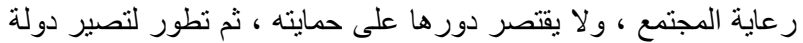

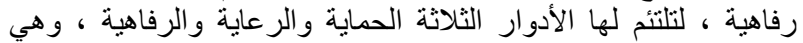

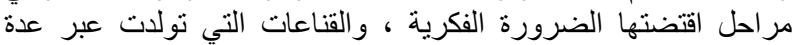

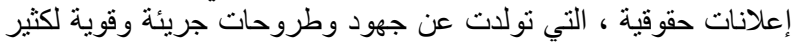

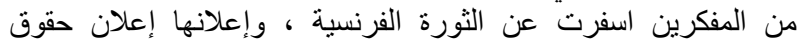

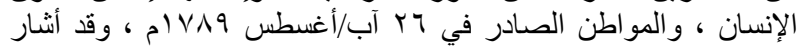

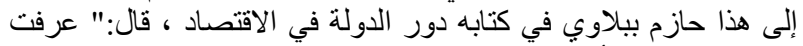

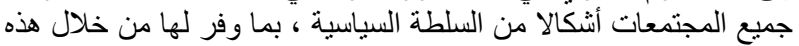

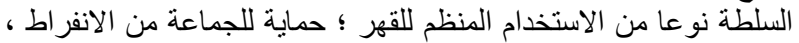

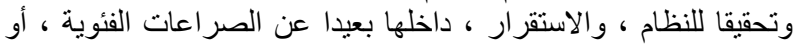

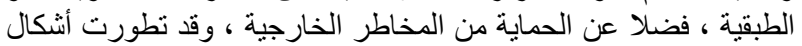

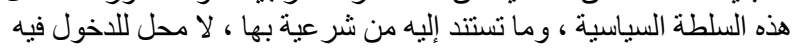

الليبرالية - العلاقة بين الحرية الفردية، والملكية الخاصة، فالاعتراف بمجال خاص يستقل الفرد بـ دون تدخل؛ يتطلب أن تتوزع الملكية، ولا تتركز في باصني

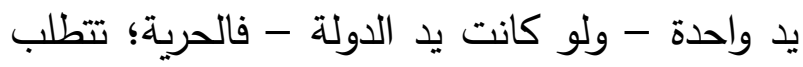
تتوع الملكيات، ومن هنا تصبح الملكية الخاصة شرطا لحرية الأفراد"(19)، وهذا يقتضي أن تونات زوال النظام السابق أدى بالضرورة، وضمن حتمية طبيعية ؛ لوجود بقاع من الأرض لا يد عليها، ولا تدخل في

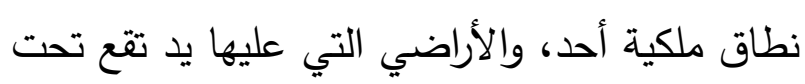
تصرف تلك اليد، وهذا بالفعل الذي حدث إذ صدرت قوانين تشرع ذلك(19r)، وهذا يعني أن البلاد التي

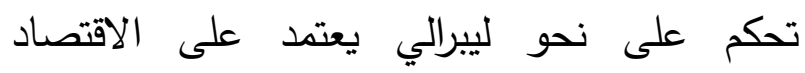

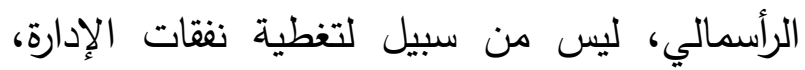

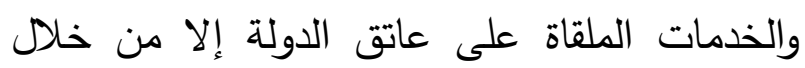
الضريبة؛ لأن الدولة كيان يضم أرضا وشعبا ونظاما

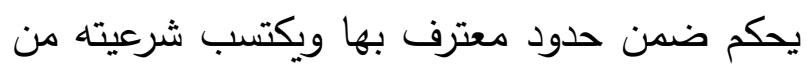

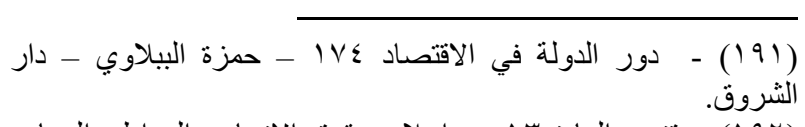

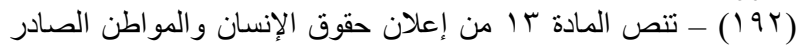

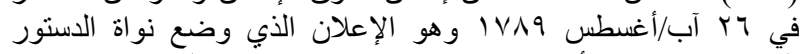

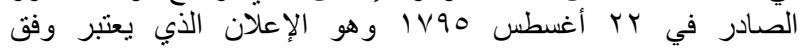

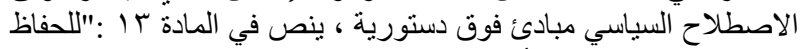

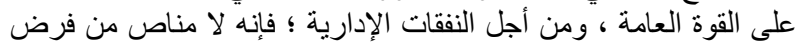

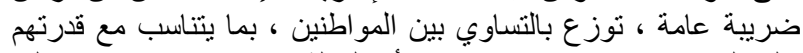

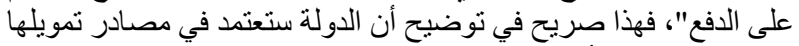

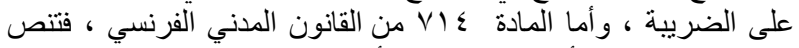

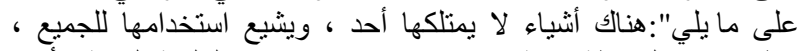

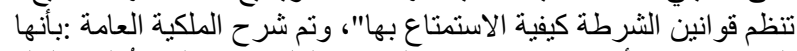

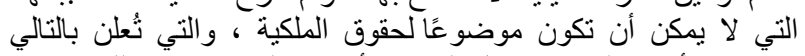

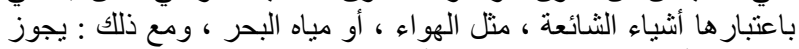

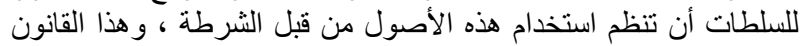

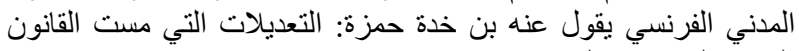

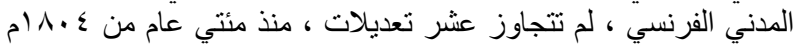

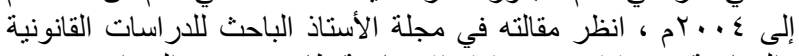

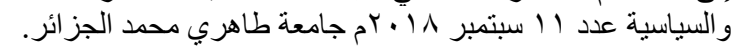


- وتكون محددة طبقا لنوع الخدمة الحكومية المقدمة، ولا تفرض إلا طبقا للقانون، ولا تزيد ولا تتقص إلا بالقانون، ولهذا تتم الموازنة بين العقيدة الراسخة في حق الفرد بالتمتع بثمار جهده، وحقه في الحرية الكاملة في التصرف بأمواله، وبين حق الدولة في القيام بمهامها لحمايته، التي تضمن انتفاعه الحقيقي بثمار جهده، من خلال فرض الرسوم الحكومية، لقاء الخدمات المقدمة للأفراد، وذلك في أضيق نطاق، وأقل تقدير، وفي حدود ما يكفي للحماية بمعناها العام، وكلما كانت آليات الحكم التي تستخدمها الدولة لتحقيق هذه الغاية أقل، كلما تحققت أهداف الفكر الليبرالي الرأسمالي في الحكم والاقتصاد أكثر، ولهذا يكون اللجوء للضريبة في أضيق نطاق، كالجراحة للمريض، ولهذا نلاحظ الأحزاب اليمينية تدافع عن هذا الحق بشراسة، وتجعل من مدى تدخل الدولة في الاقتصاد بأي وجه معيارا للحكم على جودة الدولة وجودة أدائها الحكومي، لأن هذا يعني أنها أقرب للتمسك بمبادئ الحكم الليبرالي الرأسمالي، وتجدهم بصفة دائمة ضد الضرائب؛ لأنهم يعتبرونها وسيلة لتشويه، وإعاقة عمل الدورة الاقتصادية، كما أن الجلطات تعيق الدورة الدموية في جسد الإنسان، لكن هذا التصور الذي لا زالت جميع الأحزاب اليمينية التي يطلق عليها لفظ المحافظين نعم لا يزالون يؤمنون به، واجه الانتقادات الكبيرة ؛ لأنه يحول دون قيام الدولة بدورها في رعاية المجتمع، فالمجتمع يفتقر إلى الرعاية بدرجة لا تقل عن افتقاره
من القوانين ما يحقق هذه الثمرة، وتتقاضى رسوما حكومية - وهي ضريبة في حقيقتها كما سيأتي بيانه

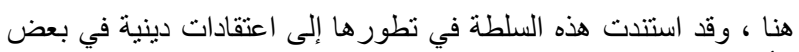

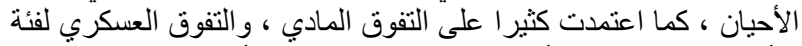

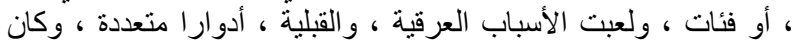

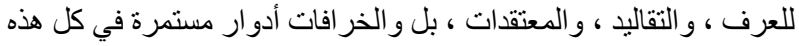

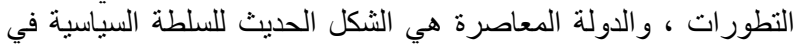

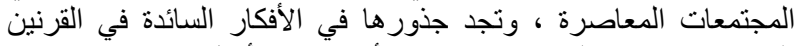

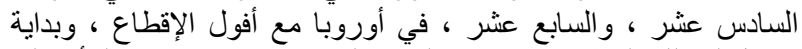

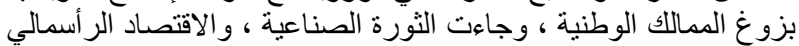

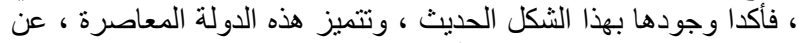

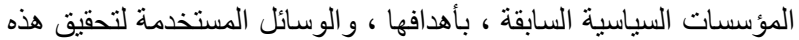

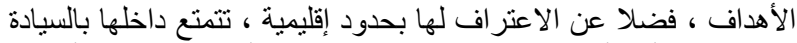

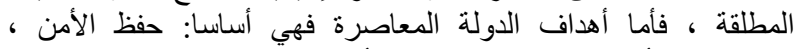

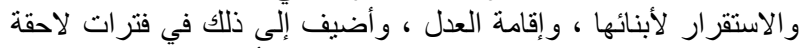

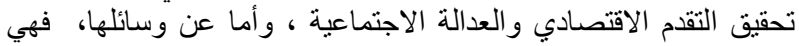

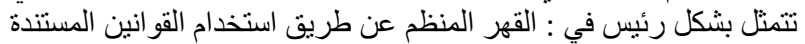

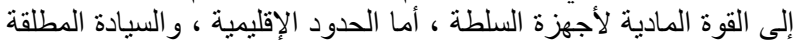

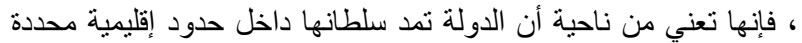

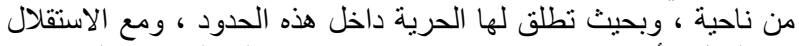

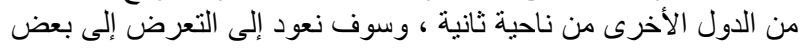

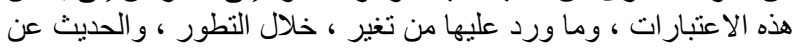

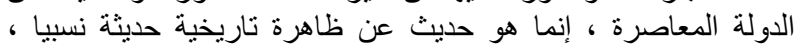

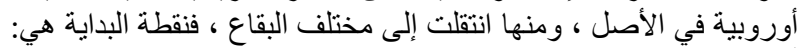

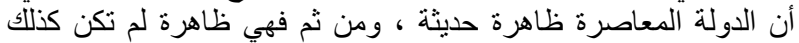

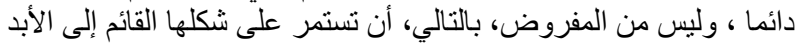

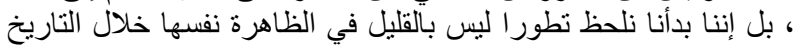

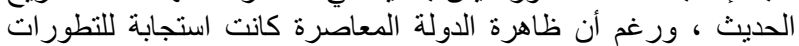

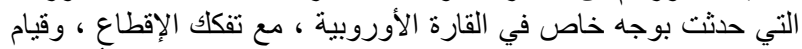

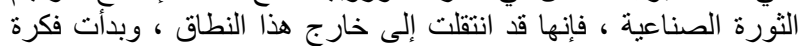

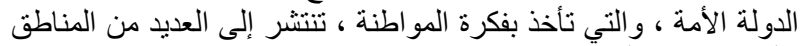

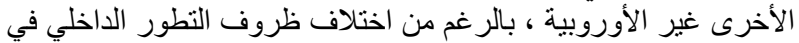

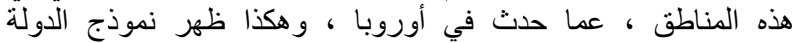

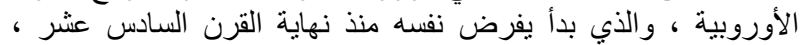

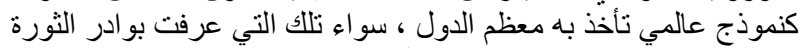

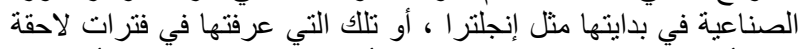

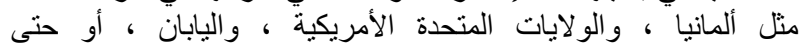

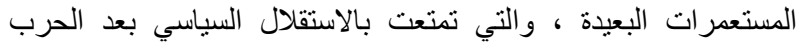

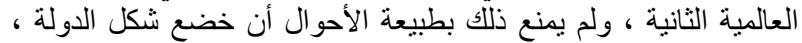

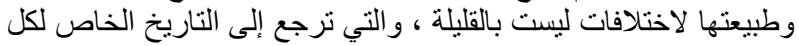

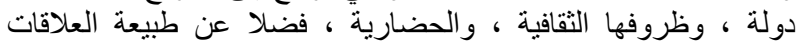

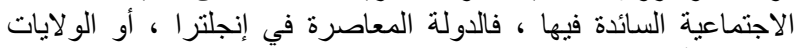

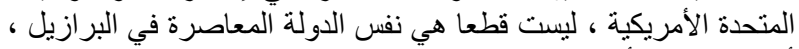

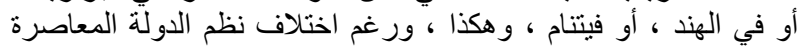

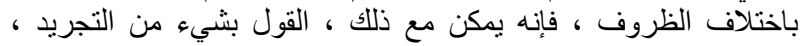

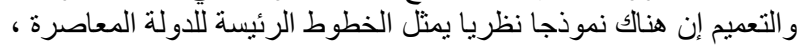

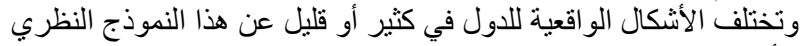

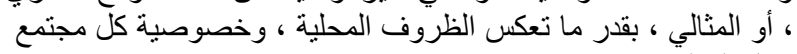

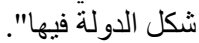


جميع هذه الدار، ومشاع فيها، أي ليس بمقسوم، ولا معزول...هذه الدار شيعة بينهم أي مشاعة" (190).

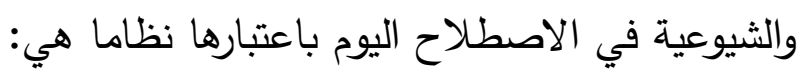

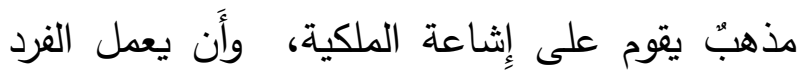

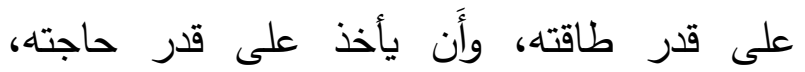

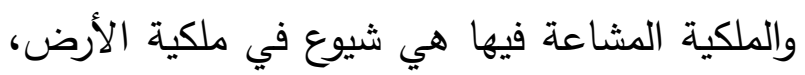
ووسائل الإنتاج لمصلحة الشعب كله، فهي مصطلح

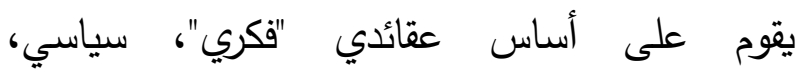
واجتماعي، واقتصادي، يعتمد من الناحية الاقتصادية

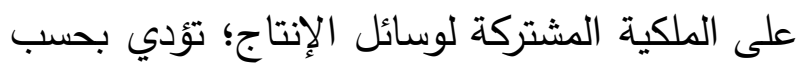
منظريها لإنهاء الطبقية الاجتماعية، ولتغير مجتمعي يؤدي لانتفاء الحاجة للمال(197). وتجدر ملاحظة أن الثيوعيين، يرون أنها مرحلة

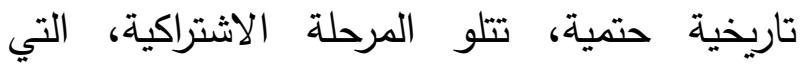
ستتحول إليها البشرية حتما أيضا، بعد انفراط حبل الئلئل

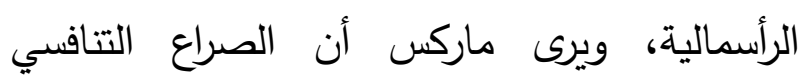
للبرجوازية يولد العهد اللاقومي الذي يغلب عليه الطابع التجاري، والحرفي الاحتكاري، وتحول الربح التنافسي لجهة الربح الاحتكاري؛ سيؤدي حتما إلى الى الى الفيح ثورات تفرض النظم الاشتراكية، ليتقاضى كل فرد في المجتمع حسب عمله، وليبذل قصارى جهده لمصلحة المجموع، ما يمهذ للقضاء على الملكية الخاصة، وتأتي الشيوعية كتطور تاريخي حتمي بعد مرحلة

(190) - (197) - لسان العرب (19) (19).

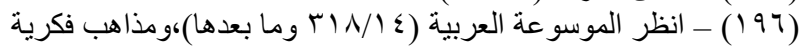

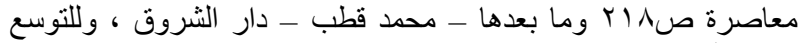

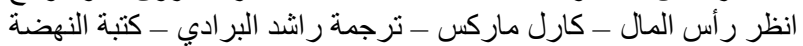

للأمن، وسيأتي مزيد شرح لهذا لدى الحديث عن النظم الاشتراكية، والثيوعية.

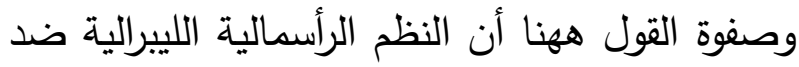

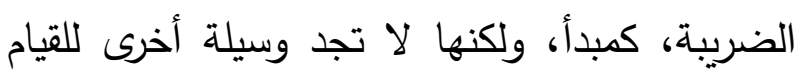

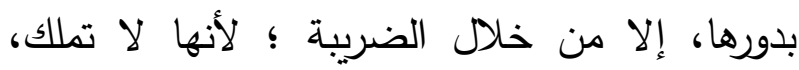

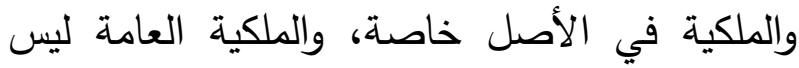
موجودة، إلا في أضيق حدود، وبقدر الحاجة، ووفقا

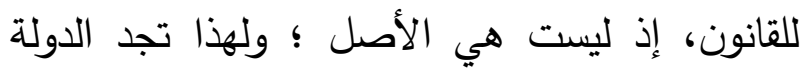
نفسها مضطرة لفرض المزيد من الضرائب، لتنتقل من الدور المقتصر على الحماية، لتصبح دولة رعاية فضلا عن دولة الرفاهية، ما يجعل الهيئات التشريعية مضطرة للمراجعة الدائمة لمستويات الضريبة، وتختلف باختلاف تشكيل تلك الهيئات، ونوعية الغالبية التي تتشكل منها تلك الهيئات، وانتماءاتهم الفكري، ولهذا نجد الضرائب في الدول التي توصف

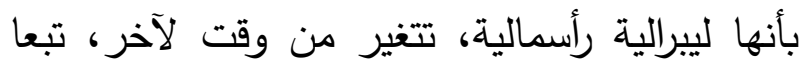
لطبيعة الدكون الذي تتشكل منه تلك الهيئات، وتبعا للحاجات التي ترعاها الدولة. بهذا أكون قد أتيت على أهم ما يتصل بأسس فرض لأه

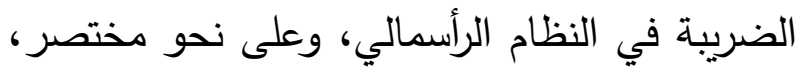
و الآن أشرع بذكر ما يتصل بالنظام الثيوعي، ومن وعن لهن بعده أتحدث عن الاشتراكي، ثم أتحدث عن المختلط، وأنهي بالحديث عن النظام الإسلامي. ثالثا:النظام الشيوعي الثيوعية في اللغة : مصدر صناعيّ من شُيُوع، قال في لسان العرب :"يقال: نصيب فلان شائع في 
للرأسمالي، ولهذا سيكتشف العمال أنهم ضحايا لهذا الاستغلال في شتّى أنحاء الأرض، وعندها سيتّخذ

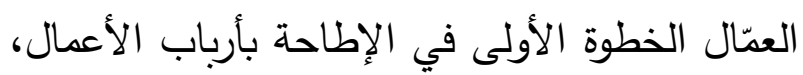

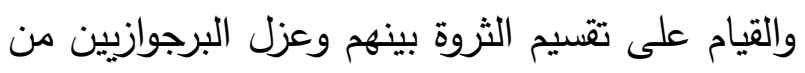
معادلة الرّبح، هذا التصور يجده ما كس حتميًا

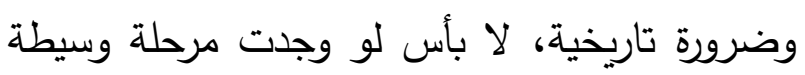

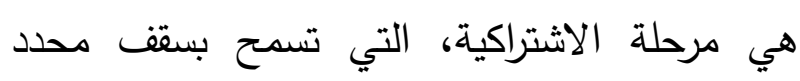
للرأسمالية طبقا للقانون. يتلخص مما سبق أن الفرق بين الثيوعية والاشتراكية، يتلخص بالشعارات التالية:

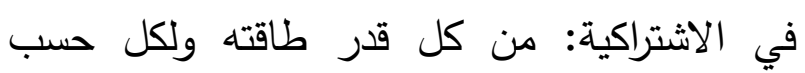
اجتهاده وإلى سقف محدد. في الشيوعي: من كل قدر طاقته، ولكل قدر حاجته فقط في (199).

والآن ما علاقة هذا الطرح بالضريبة؟ الجواب: إن المتأمل في النظام الثيوعي يعلم أنه نظام لا ضريبة فيه، أصلا ولا بطالة، لأنه يقوم على في لئل

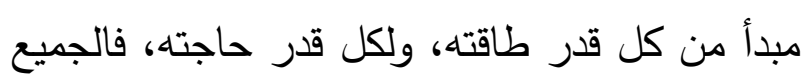

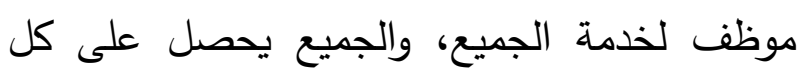
احتياجاته من الجميع، والدولة تعتمد في تحقيق هذا لهيع لهمئ

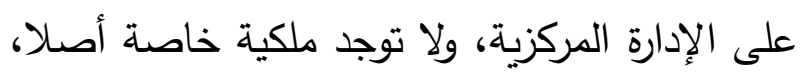

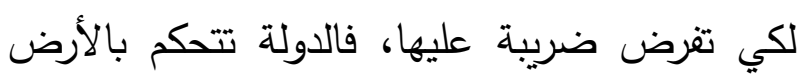
وما عليها، وتتكفل بالأرض وما عليها، والتخطيط

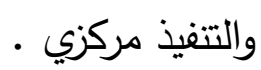

الاشتراكية، هكذا يتصورون(19V)، ومن ميزات العهد

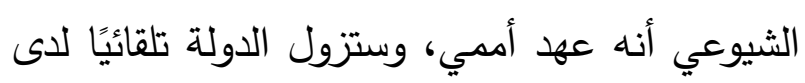
بزوغ فجره؛ لتصبح البشرية في دولة واحدة، وهذا

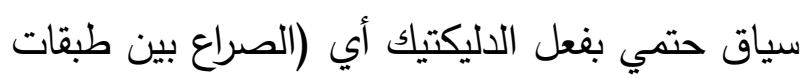

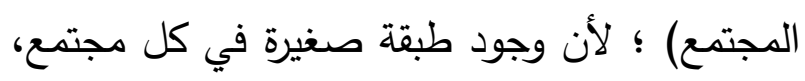

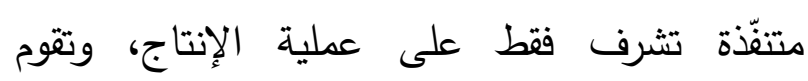

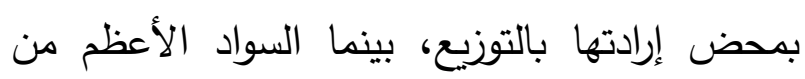

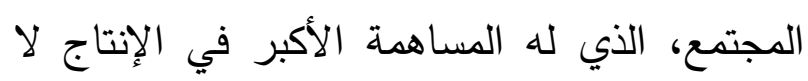

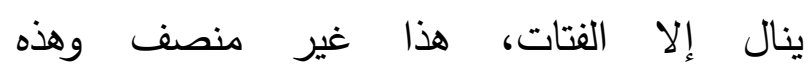

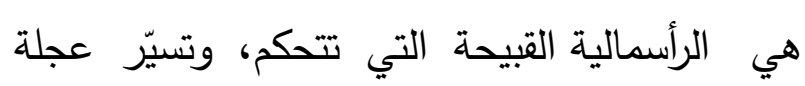

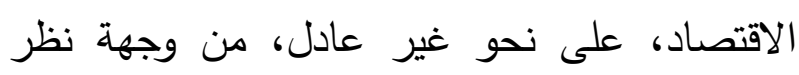
كارل ماركس، فهو استغلال من قدو فيل الطبقة البرجوازية للطبقة الكادحة، فأرباب الأعمال يشترون فئل فئل وقت العامل عن طريق دفع راتب مقطوع لهذا

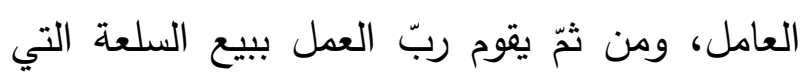
يصنعها العامل بفارق ربح، وعليه ففارق الربح في لهي الحقيقة ليس سوى عمل العامل، الذي ولهذا كان

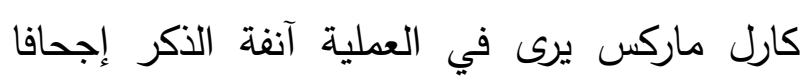

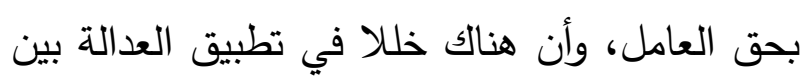

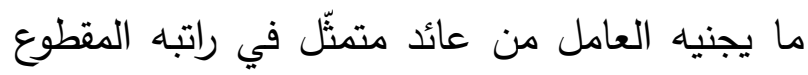
وبين الربح الفاحش الذي يجنيه أرباب الأعمال(191)،

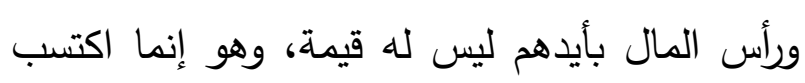

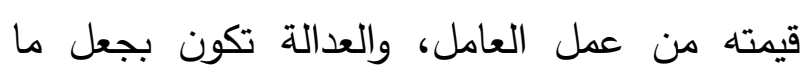

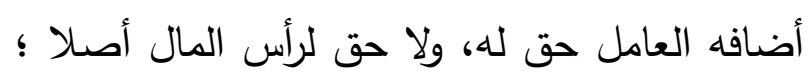

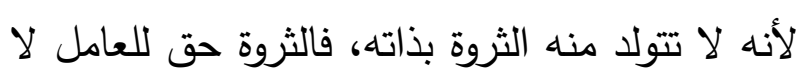


والدارس لتاريخ الاتحاد السوفيتي يلحظ بجلاء وجود صراع كبير لم يخل عن فضائع يرتكبها النظام الشيوعي ؛ من أجل التسريع بتنفيذ غايات الدستور الشيوعي، ولم تأت فترة الستينات وتحديدا في المؤتمر الحادي والعشرون للحزب الثيوعي المنعقد عام 909 ام إلا وقد اتخذت توصية بإلغاء

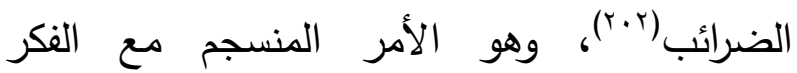
الشيوعي، ولكن تلك التوصيات، والقوانين تم التراخي في تتفيذها، ومع الأيام تم تجاهلها ؛ وهذا يوضح مدى الفرق بين النظرية وطموح صاحبها، وبين الواقع العملي، وحاجات بني البشر •

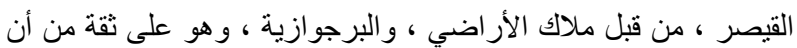

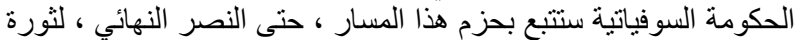

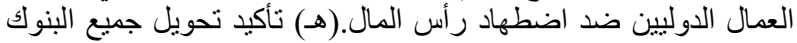

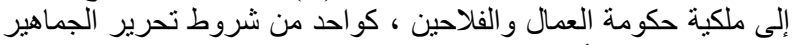

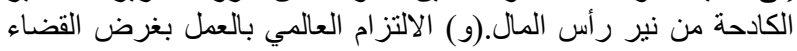

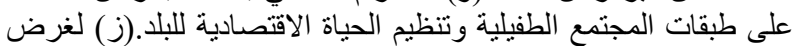

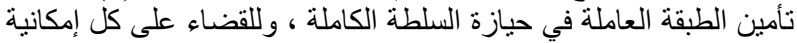

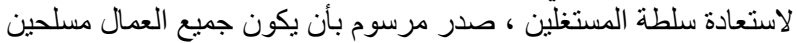

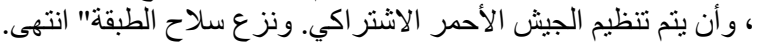

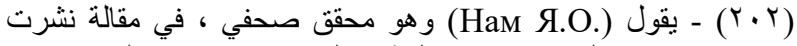

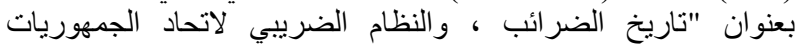

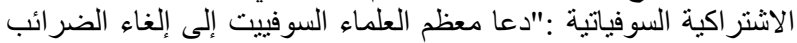

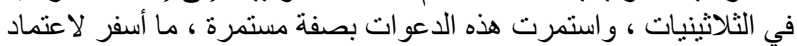

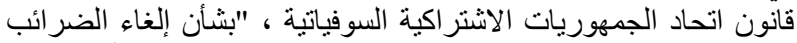

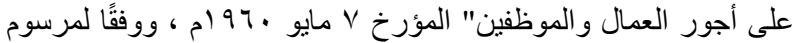

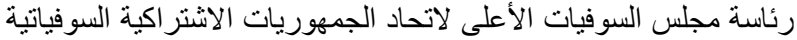

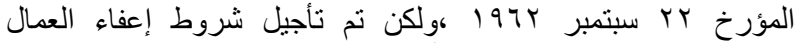
و الموظفين من الضر ائب على الأجور ، ثم تم تجاهل هذه الفئر الفكرة تمائًا". http://storyo.ru/print:page,1,413-istorija-nalogovnalogovaja-sistema-sssr.html

وتكرر هذا المعنى في مقالات عدة انظر الرو ابط: https://studme.org/1321110620900/ekonomika/nalogi_s ssr_1917-1991 https://bankfs.ru/ar/deposits/kakie-nalogi-s-zarplatyplatili-v-sssr-nalogovaya-sistema.html
غير أنك لو راجعت دستور الاتحاد السوفيتي باعتباره أول دستور لدولة شيوعية - تجد تفصيلات تتعلق بالضريبة، وهي في المادة الخامسة، الفقرة

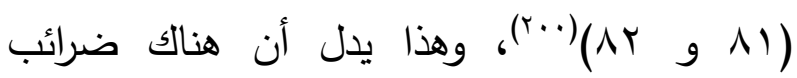
تفرض على الناس في المجتمع الثيوعي، فكيف تقول: لا يوجد؟

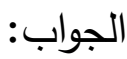

نجده أيضا من الدستور السوفيتي ؛ لأنه قبل ذكره للضريبة، يذكر أنها حالة يقتضيها التدرج من المجتمع الرأسمالي، إلى المجتمع الشيوعي، وهذا

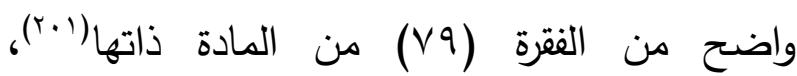

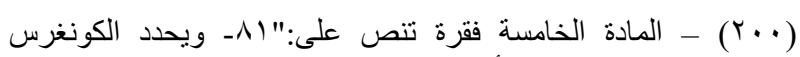

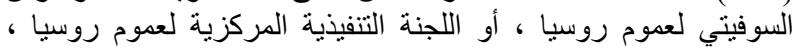

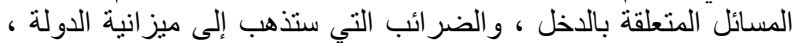

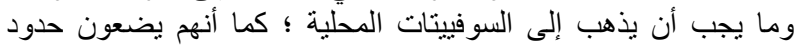

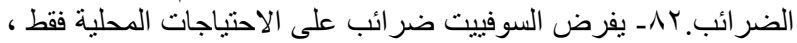

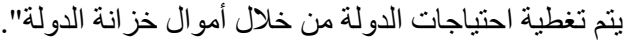

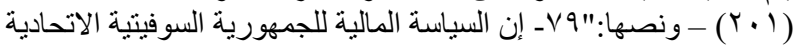

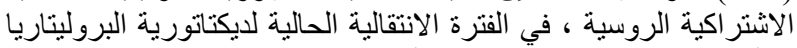

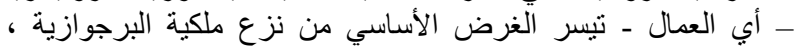

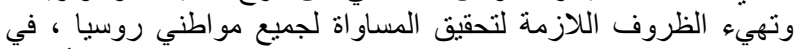

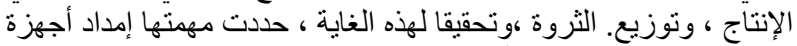

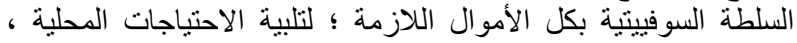

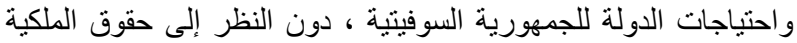

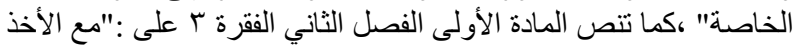

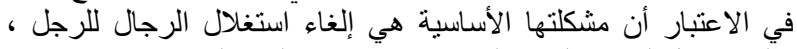

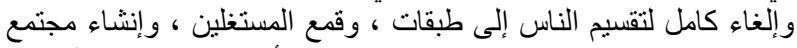

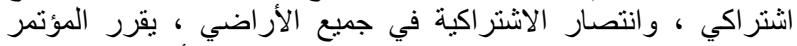

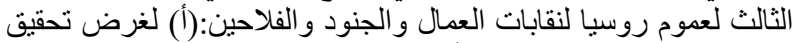

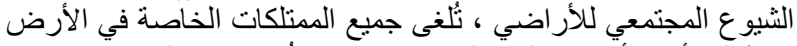

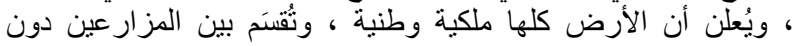

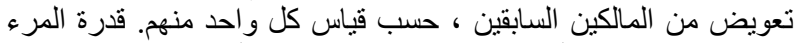

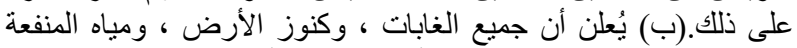

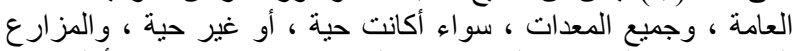

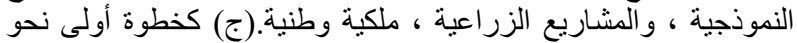

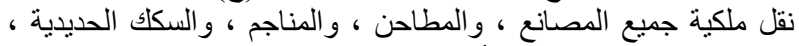

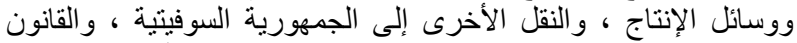

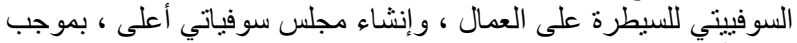

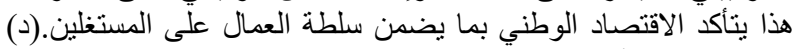

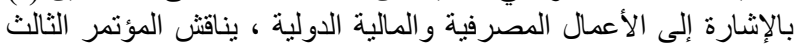

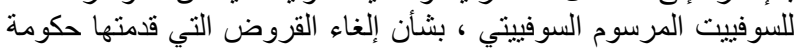


ولدينا تجربة أظهرت بجلاء التطبيق العملي للفكر

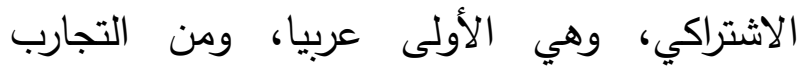
المتقدمة عالميا، وقد كرسها، وأبرز جوانبها التطبيقية ولتئي دستور الجمهورية المصرية الصادر في 17 يناير سنة 1907 ؛ إذ ينص في ديباجته، وعدد من مواده، التي سأذكر منها موطن الثاهد على ذئه دكرته، وسأعلق عليها من بعد، وهي على النحو الآتي :نحن الشعب المصري الذي انتزع حقه في الحرية، والحياة، بعد معركة متصلة ضد السيطرة المعتدية من الخارج، والسيطرة المستغلة من الداخل، نحن صند الشعب المصري الذي تولى أمره بنفسه، وأمسك منك زمام شأنه بيده، غداة النصر العظيم الذي حققه بثورة r r يوليو سنة 90 ام، وتوج بنه كفاحه على مدى التاريخ، نحن الشعب المصري الذي استلهم العظة من ماضية، واستمد العزم من حاضره؛ فرسم معالم

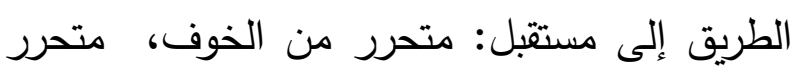

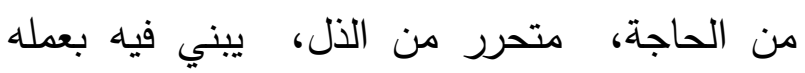

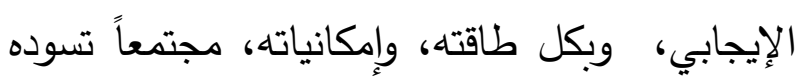

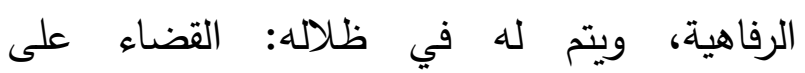

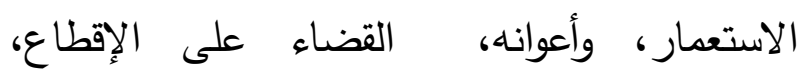

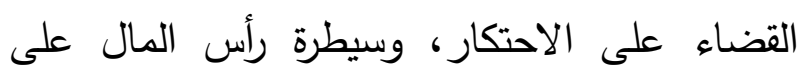

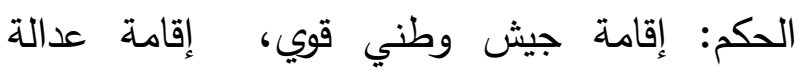

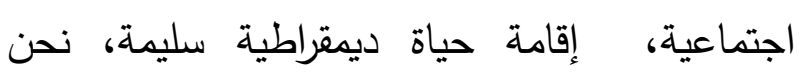
الشعب المصري الذي يؤمن بأن: لكل فرد حقاً في يومه، ولكل فرد حقاً في غده، ولكل فرد حقاً في لئن

ولكن لا يأخذون بآر اء لينين ، و هذا طرح غير موضوعي ، و غير محدد ،

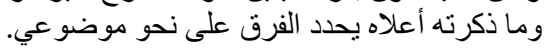

رابعا: النظام الاشتراكي: - الإئ

تقوم الاشتراكية على المبادئ والأفكار التي تقوم الأنسرجئ

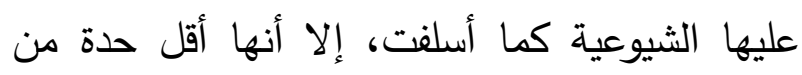

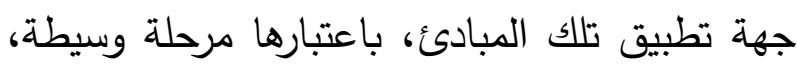

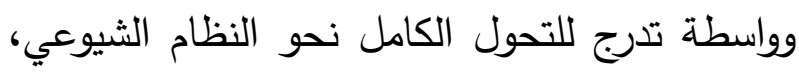
وإذا كان شعار الثيوعية من كل قدر طاقته، ولكل قدر حاجته، فالاشتراكية ترفع شعار من كل قدر لـن

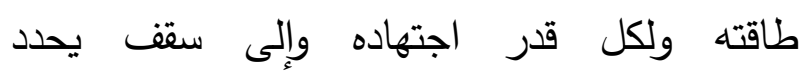
القانون(r+r)، ومن طبيعة اللفظ يظهر أن القصد من لن

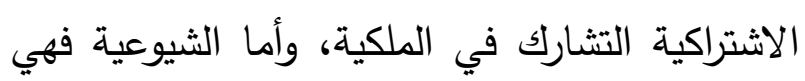
تعني شيوع الملكية، وما ينتجه المرو باجتهاده فليس وليس

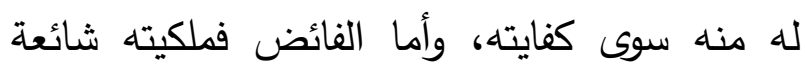
تديره الدولة، ولا تتعلق به ملكية خاصة، وأما النظام الاشتراكي فهو يوافق على قدر من الملكية الخاصة

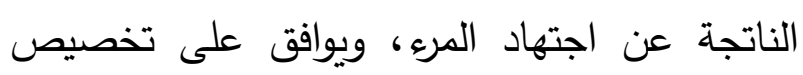
قدر ضمن سقف محدد من الثروات لجهة، أو جهات خاصة في إطار قانوني، مع بقاء الأصل في ملكية الثروات الطبيعية، وباقي عوامل الإنتاج ملكا عاما لإهي للدولة، والناس فيها شركاء، وتديره الدولة طبقا للقوانين (؟-r)

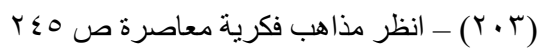

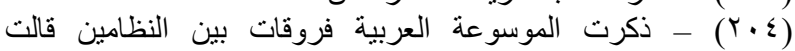

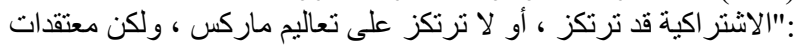

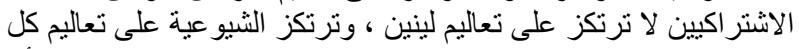

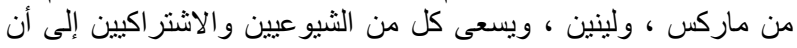

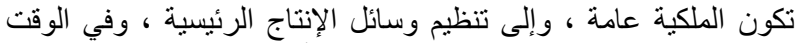

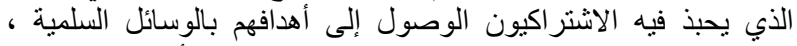

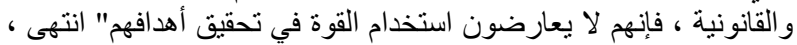

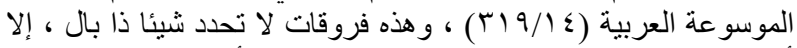

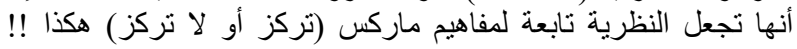


عقيدته، ولكل فرد حقاً في فكرته، حقوقه لا سلطان ولا يجوز أن يتعارض في طرق استخدامه مع الخير

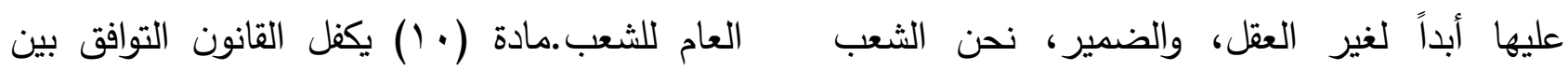

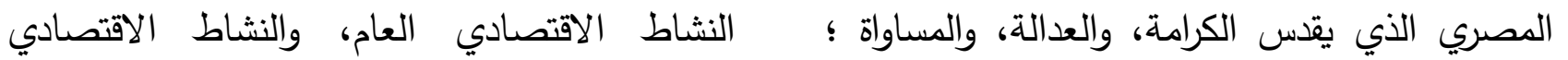

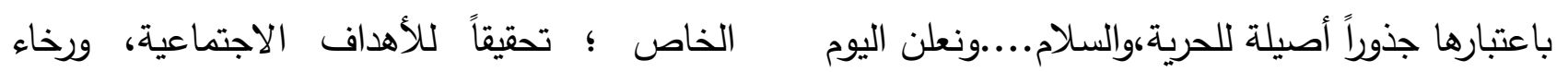

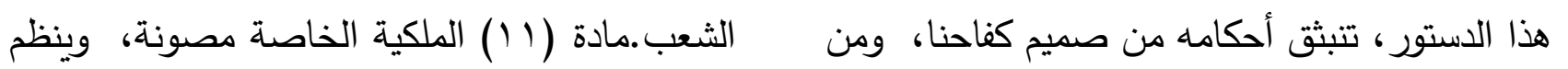

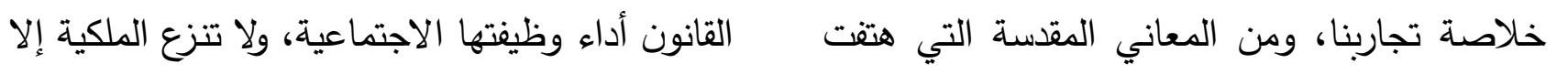

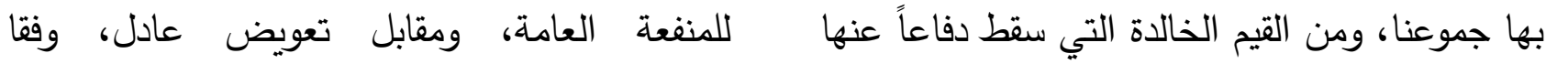

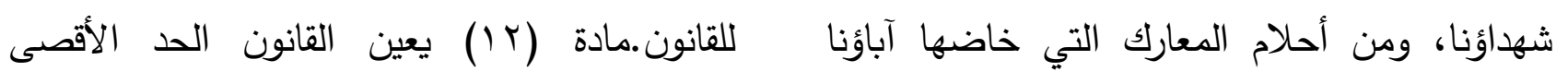

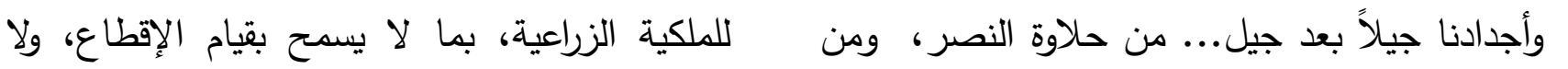

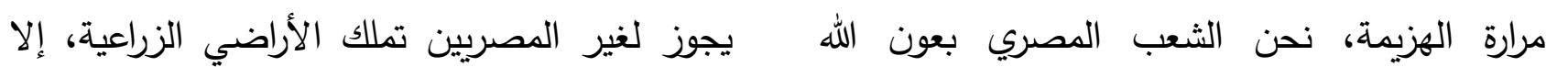

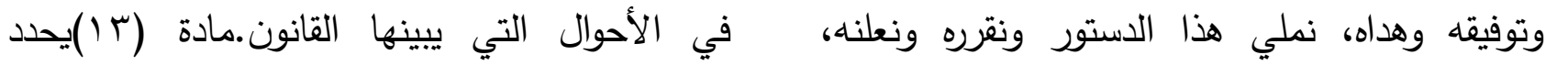

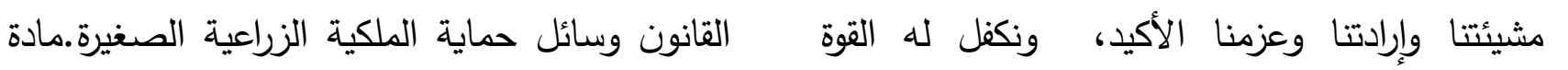

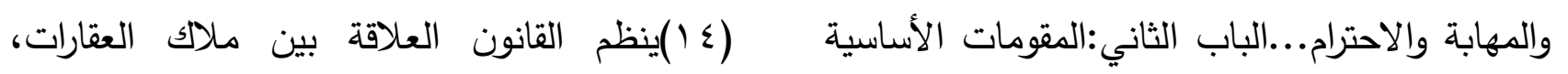

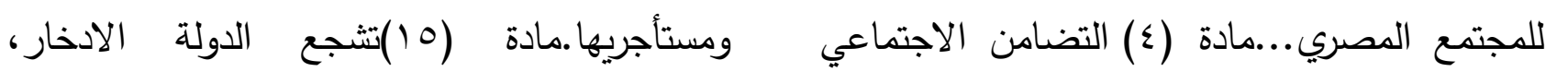

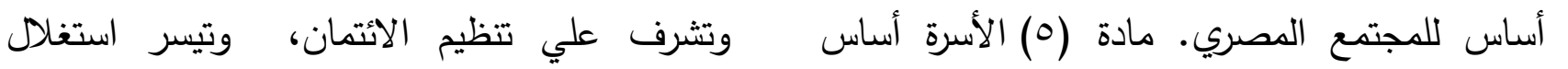

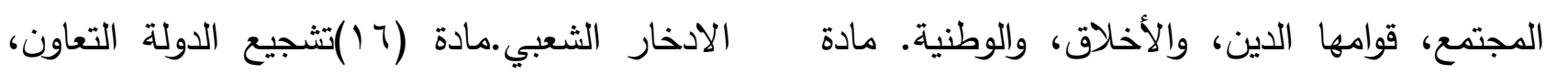

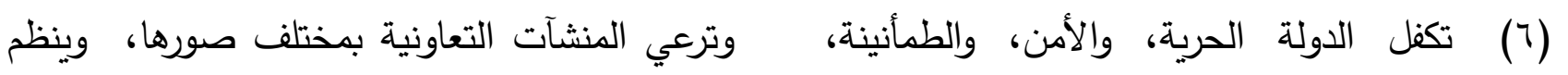
وتكافؤ الفرص لجميع المصريين.....مادة القانون الأحكام الخاصة بالجمعيات التعاونية.مادة

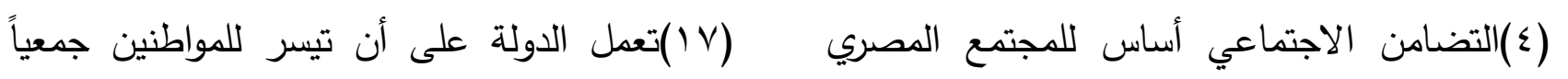

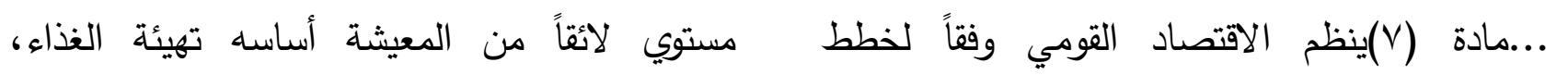

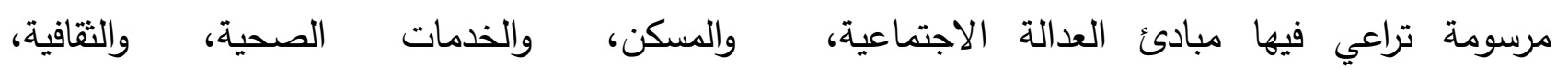

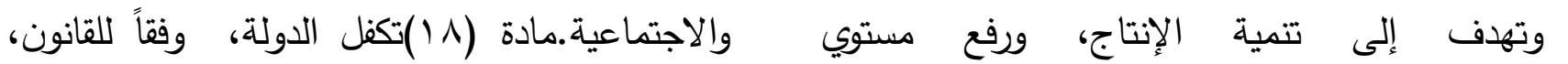

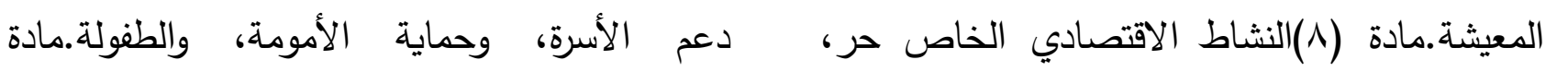

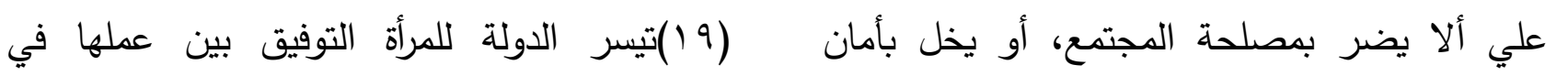

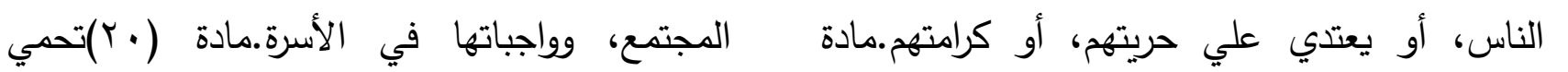
(9)يستخدم رأس المال في خدمة الاقتصاد القومي، الدولة النشء من الاستغلال، وتقيد الإهمال الأدبي، 
الزراعية، واعتبار الدولة مالكة لكل الثروات، وكل إشارة لحماية الملكية الخاصة فهي إثارة إليها من أجل وضعها ضدن سقف تحدده القوانين، ولا يفهم من الحديث عن الحفاظ على الملكية الخاصة حفاظا عليها على سبيل الإطلاق، وإنما هو شيء محدد بالقانون، وما زاد فهو عرضة للمصادرة، من أجل تحقيق التضامن الاجتماعي، والحيلولة دون استئار القلة بالثروة، ولاحظ تعهد الدولة بتأمين العمل لكل راغب فيه ما يشير لعدم وجود بطالة أو لانخفاضها إلى أدنى مستوياتها(؟r+r)، وهي إفراز طبعي للأخذ بفلسفة النظم الاشتراكية (r.v). ما علاقة ما سبق بموضوع الضرائب؟

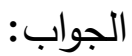
إن الناظر في النظام الاشتراكي يعرف أن الضرائب فيه تكون في أقل مستوياتها، لسبب ذاته الذي يجعل

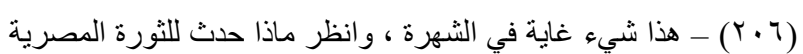

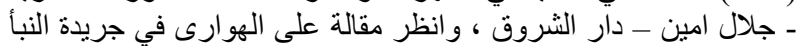

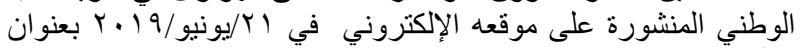

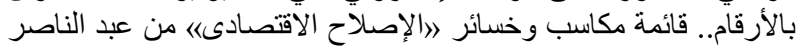
الر ابط

ضمن

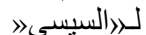
https://www.elnabaa.net/769489

من (Y.V)

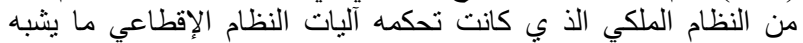

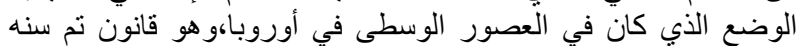

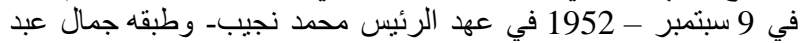

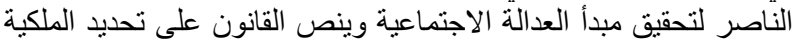

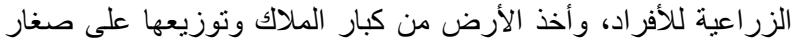

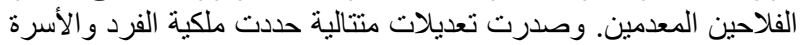

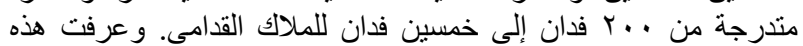

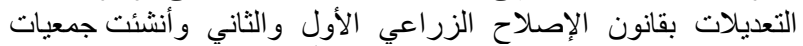

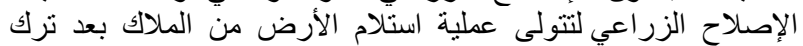

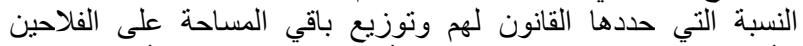

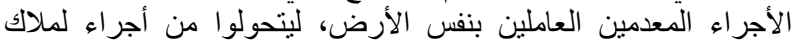

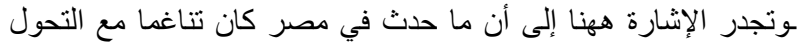

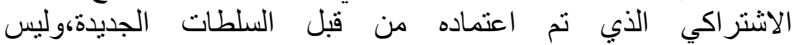

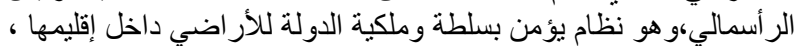
وأن الملكية الخاصة محددة طبقا للقانون.
والجسماني، والروحي.مادة ( (Y)للمصريين الحق في

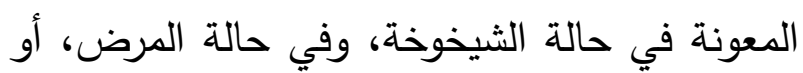
العجز عن العمل، وتكفل الدولة خدمات التأمين الاجتماعي، والمعونة الاجتماعية، والصحة العامة، وندي،

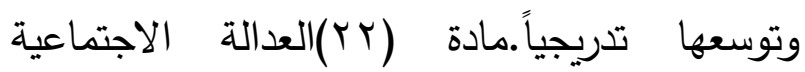

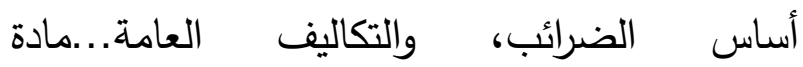

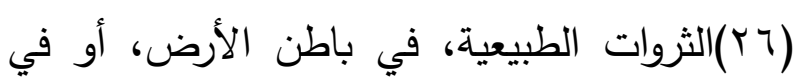
المياه الإقليمية، وجميع مواردها، وقواها ملك للدولة، وهي التي تكفل حسن استغلالها مع مراعاة مقتضيات

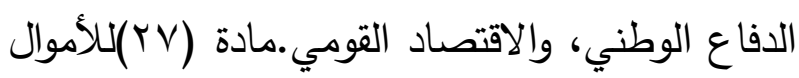

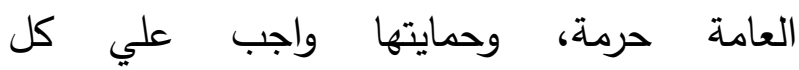

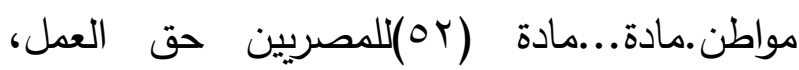
وتعنى الدولة بتوفيره....مادة (9^)ينظم القانون

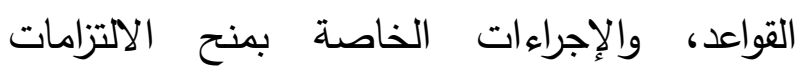

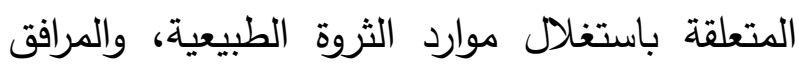
العامة، كما يبين أحوال التصرف بالمجان في لعاردي

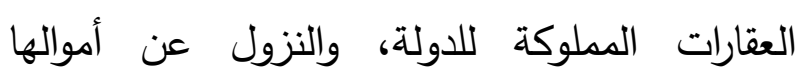
المنقولة، والقواعد، والإجراءات المنظمة لها" انتهى

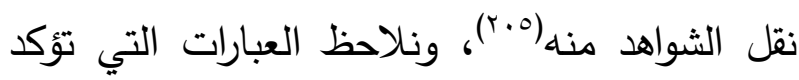
على إلغاء الإقطاع، وإعلان التضامن المجتمعي، وني،

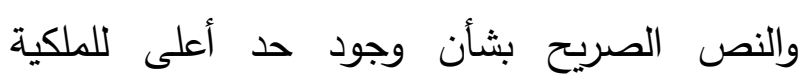

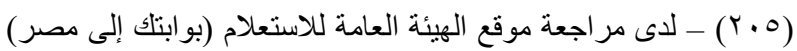

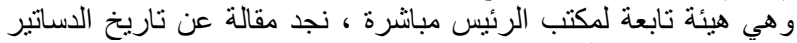

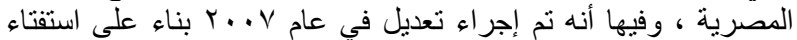

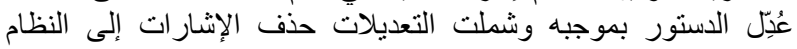
الاشتر اكي للاولة ؛ انظر الر ابط: https://www.sis.gov.eg/Story/57175/\%D8\%AA\%D8\%A7\%D8 $\% \mathrm{~B} 1 \% \mathrm{D} 9 \% 8 \mathrm{~A} \% \mathrm{D} 8 \% \mathrm{AE}-$ \%D8\%A7\%D9\%84\%D8\%AF\%D8\%B3\%D8\%AA\%D9\%88 $\% \mathrm{D} 8 \% \mathrm{~B} 1-$ \%D8\%A7\%D9\%84\%D9\%85\%D8\%B5\%D8\%B1\%D9\%8A?1 
فبرغم سيطرة مبادئ الفكر الرأسمالي، وبرغم سطوة

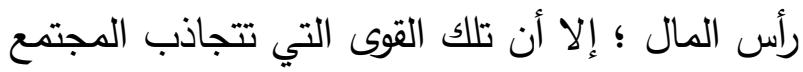

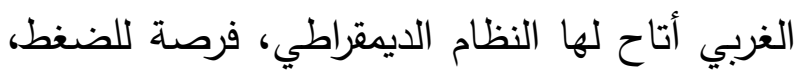
والمطالبة بتحسين أوضاعهم، ولا يكتقون بالصمت،

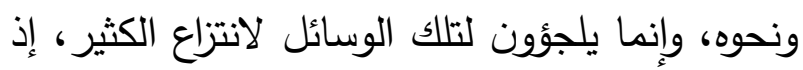
تجيز القوانين لديهم "دستوريا" حق التظاهر السلمي والإضراب بشروط وضوابط محددة، كي لا يكون

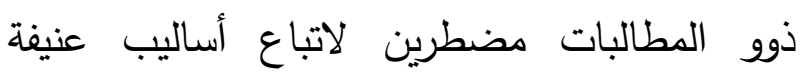
للحصول على مطالبهم، ولتبقى أبواب التواصل مشرعة للحوار وتدارس المطالب التي سيكون الجميع معني بتحقيقها حفاظا على الكيان القائم، وهو توازن أفرزته الديمقراطية، فلم يكن لتوجد نظام العمال،

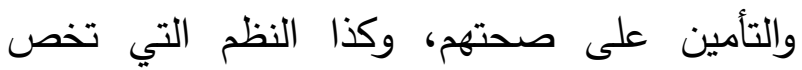
التقاعد لهم، وفرض مجانية التعليم، والصحة ؛ لولا تلك الضغوط، والتي يراد لها في النهاية أن تسفر وصران عن الحد الأدنى من "لدولة الرفاهية"، فالرأس مالية تجعل كل شيء فرصة للبيع، وفي الحقيقة هناك حجج فلسفية توجد لاى الرأسماليين تدافع عن هذاء ولنيا التوجه، وليس هذا البحث مخصصا لدراستها،

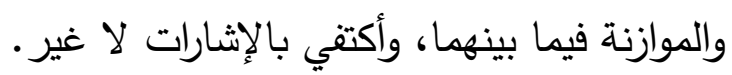

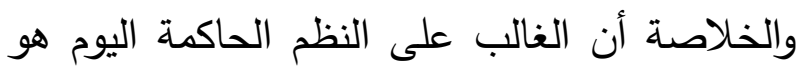
قيامها على أسس مختلطة طبقا للتوصيف أعلاه ؛

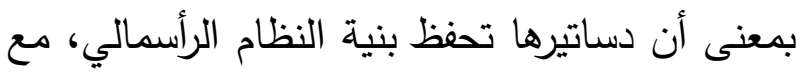
تقييده بقيود تحفظ حقوق الأقل حظا من الناس، ونأخذ مثالا لهذا دستور الجمهورية الألمانية الذي مهي

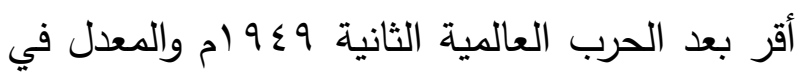

الغاء الضرائب متعينا في النظام الثيوعي، ولكن بدرجة أقل تتناسب طرديا مع الملكية التي يتيحها القانون في الدولة الاشتراكية، والمطالع لتاريخ الدول التي اعتمدت النظام الاشتراكي يلحظ هذا بجلاء، والإشكال في الدول التي أعلنت نفسها دولا شيوعية ؛

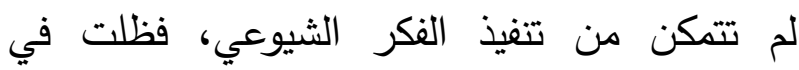
المرحلة الاشتراكية، وبدرجات متفاوتة، ولست بوارد

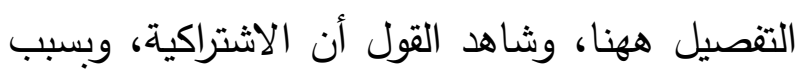
طبيعة نظامها، لا تميل لفرض الضرائب، إلا في حدود ضيقة وموجهة لشرائح محددة طبقا لقانونها

خامسا: النظام المختلط. إن معظم دول العالم الآن تعتمد النظام الاقتصادي

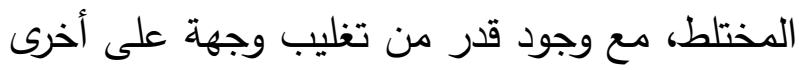
تارة بعد تارة، وكل ذلك بحسب القوانين التي تسن،

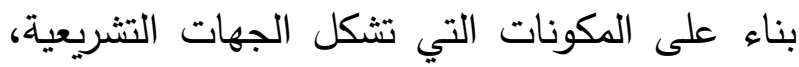
غير أن النظام المسيطر في معظم الحالات يميل نحو كفة النظم الاشتراكية مع الحفاظ على غطاء ومبادئ النظم الرأسمالية، ما يعني أن التشرائ عيع التشيعات تقتصر على الحد الأدنى الذي يحقق فكرة دولة لرئة

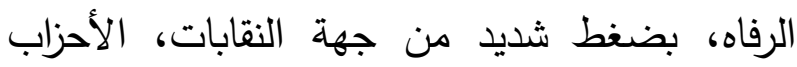

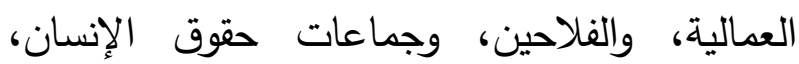

الطال

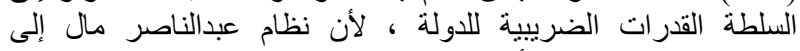

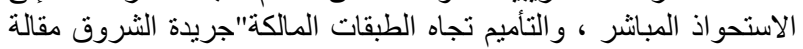

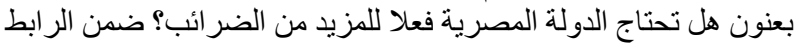
https://www.shorouknews.com/columns/view.aspx?cdate=180 $\underline{\text { 12010\&id=c8cf1171-cd3f-4221-b9d8-96ffaa8ba5af }}$ 


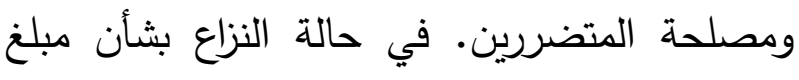
التعويض، يمكن اللجوء إلى المحاكم العادية. المادة 0 ـ [التحويل إلى الملكية العامة ] يجوز تحويل الملكية الخاصة للأراضي، والموارد

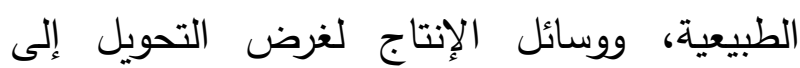
الملكية العامة، أو غيرها من أشكال المؤسسات الاقتصادية العامة، وذلك بقانون ينظم نوع لقن التعويضات، ومقدارها. وفيما يتعلق بهذا التعويض،

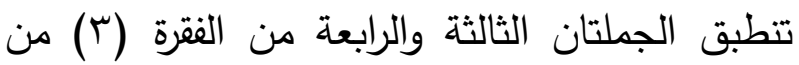
المادة ؛ ا مع إجراء التعديلات اللازمة" انتهى. هذه مواد تظهر التمسك بمبادئ الرأسمالية، وعدم وضع سقف للملكية الخاصة، بالإضافة للمواد السابقة المتعلقة بمقومات الحياة، وهي الثروات الطبيعية وغيرها، فهي صريحة أن دور الدولة في ذلك الإطار يقتصر على الحماية، والتنظيم لا غير، وهذا ينسجم مع النظام الرأسمالي، وتعهد الدولة بالرعاية ينسجم مع النظام الاشتراكي، لنجد أنفسنا أمام رأسمالية تم تخليصها من كثير من عيوبها.

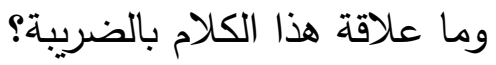

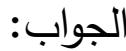
الكلام السابق يوضح أن الضريبة متى فرضت في مثل هذا النظام ؛ فهي تفرض لأن موارد الدولة لا

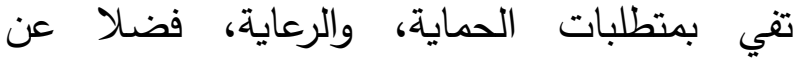
الرفاهية، في الوقت الذي لا تقع الثروات في الأصل

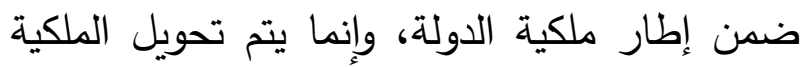
الخاصة لجهة الملكية العامة، بتعويض عادل،
ـ ا • بم إذ ينص بشأن المبادئ الدستورية على:"

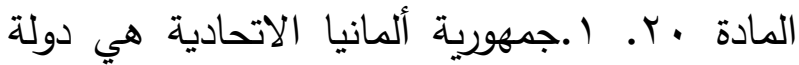

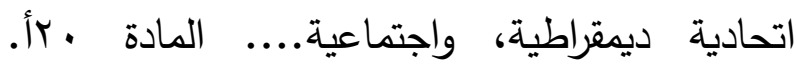
] حماية المقومات الطبيعية للحياة وحماية الحيوانات]|نطلاقاً من مسؤوليتها حيال الأجيال القادمة أيضاً، تقوم الدولة في إطار النظام الدستوري بحماية المقومات الطبيعية للحياة، وحماية الحيوانات، وذلك بوضع التشريعات اللازمة، وعبر السلطتين التنفيذية، والقضائية، وفي إطار النظام الدستوري" انتهى، ونلاحظ أنه، جعل على عاتق وفين إنى الدولة حماية المقومات الطبيعية للحياة، وحماية الحيوانات، في تأكيد على الجانب الرأسمالي للدولة برغم أن الدستور جعلها ديمقراطية اجتماعية وعبارة "اجتماعية" متى ما وردت في تعريف الدولة فهو

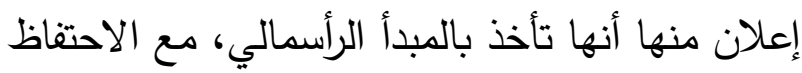
بالديمقراطية الاشتراكية، وهذا تظهره المادة ـ ا.المتعلقة بالحديث عن الملكية الخاصة - حق القنيق الإرث - ونزع الملكية الخاصة، ونصها:" 1- يُكفل حق الملكية الخاصة وحق الإرث، وتتص وله القوانين على مضمونهما ومُقيداتهما. r- حق الملكية الخاصة يستوجب التزامات. وتكون ممارسة هذا الحق لخدمة الصالح العام. r- لا يجوز نزع الملكية إلا للصالح العام. ولا يؤمر

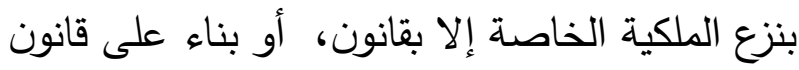

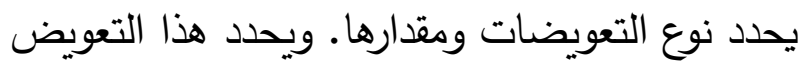
من خلال إقامة توازن عادل بين المصلحة العامة 
وإنما هو نتاج فهم نصوص القرآن والسنة(9+r)، ولكن لو قلت هو نظام مختلط، باعتبار وجود بعض وله

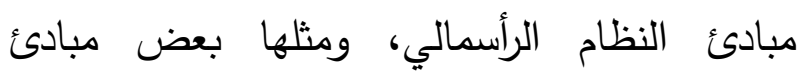

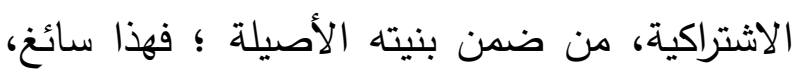
ومع هذا فليس في الإسلام إقطاع بالمعنى المعروف لإنه

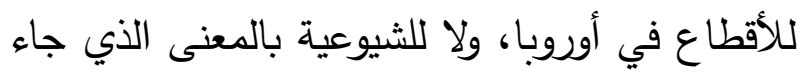

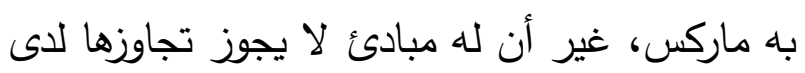
النظر المصلحي لسن بعض التشريعات الاقتصادية من قبيل السياسة الثرعية، وهي كبادئ يحسن ذكرها

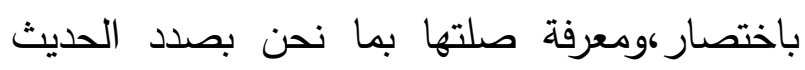
عنه بشأن الضريبة. وعليه أقول:

إننا بمراجعة أهم المصادر نجد المبادئ الآتية في

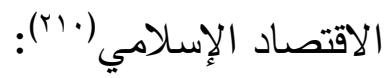

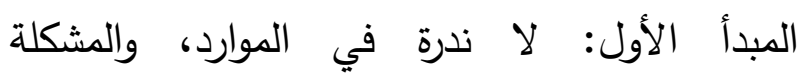
الاقتصادية من وجهة النظر الإسلامية تلعلق

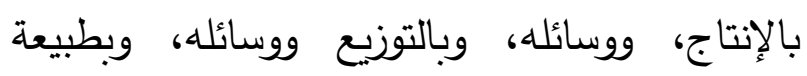
الإنسان وبتربيته، وليس بشح الموارد.

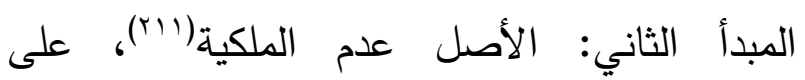

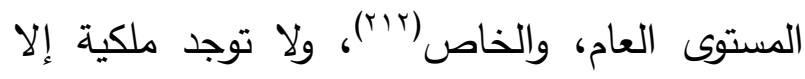

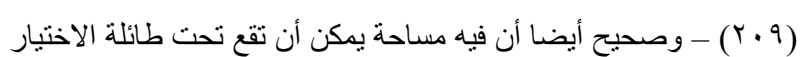

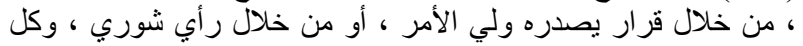

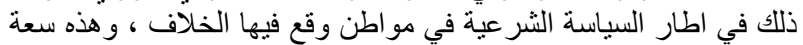

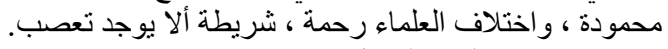

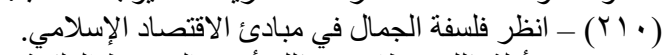

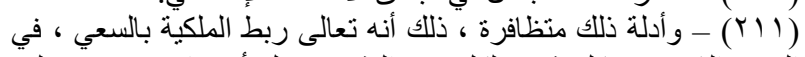

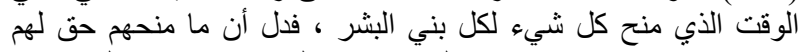

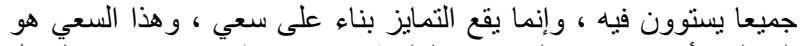

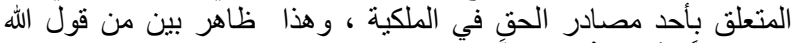

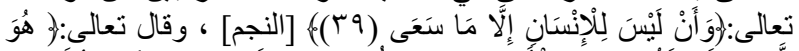

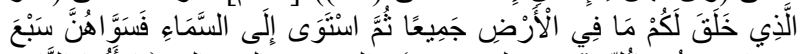

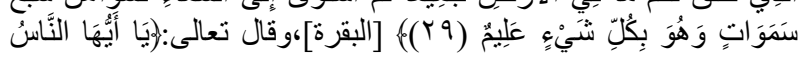

وطبقا للقانون، ولهذا فالضرائب لدى هذه الدول تتسم بالتغير من سنة لأخرى بحسب النفقات المتوقعة، وتخضع للرقابة، والمراجعة عن طريق لإئ بالجهات التشريعية التي سنت الضرائب في الأساس، وتتأثر ولثرابهات

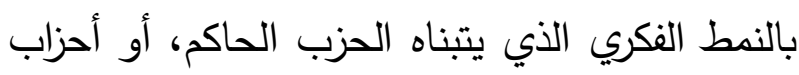

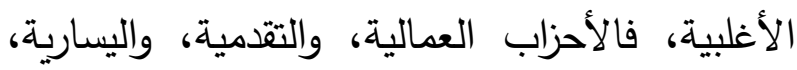
يغلب عليها الفكر الاشتراكي، الذي يركز على بذل الاعل

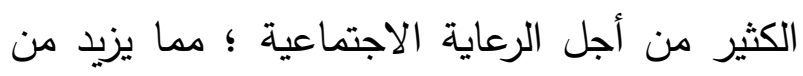

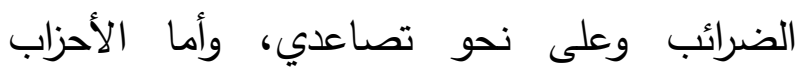
المحافظة، واليمينية فيغلب عليها التركيز على والى الهيل السوق، ويذهبون إلى أن قوة السوق تتيح للمجتمع تحقيق معدلات عالية من الاخل ؛ ما يجعل الرعاية الاجتماعية متحققة بالجهود الذاتية، وليس بتدخل

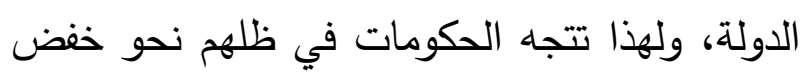
الضرائب، وتقليلها لأبعد مدى.

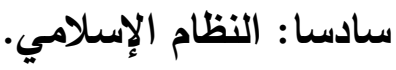
النظام الإسلامي على المستوى الاقتصادي فريد لا لإسدان يمكننا أن نضعه ضمن أي تصنيف سابق، فليس هو الإنسي على

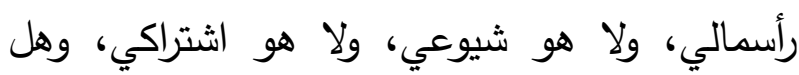

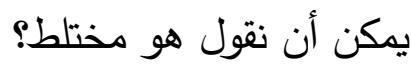

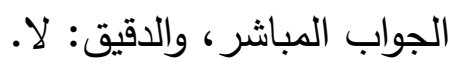
لأنه ليس نتاج قرار يصدر عن برلمان مثلا، أو ولن لأل

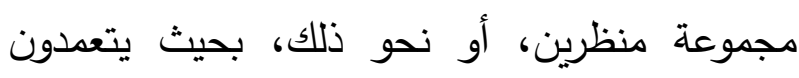

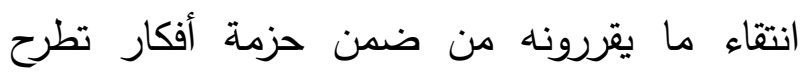
لتكون موضع نقاش، لتسفر عن قانون يلزم الكافة، 
المبدأ الثالث: لا ملكية إلا بعمل(عاب() أو عن رضى ممن عمل، بشرط مشروعية التمليك، كما أن الإسلام قرر أن للملكية أسبابا محصورة، في الإحياء، والسبق، والإرث، والمعاوضة، ومطلق العطاء، وهي أسباب اعتيادية للملكية، وأما السبب الاستثنائي فينحصر في الغنيمة، والفي، وكل ذلك بشروطه. المبدأ الرابع: للإنسان الحرية المطلقة في التنقل، والعمل في أي مجال(10)، والاكتساب من الموارد التي تتيحها الطبيعة بدون حدود، مع الالتزام بتحمل المسئولية الفردية، والجماعية طبقا للشريعة. المبدأ الخامس: لا ربحية دون مخاطرة محسوبة، أو قابلة للحساب "الربحية دون تلك المخاطرة ؛ أكل للأموال بالباطل"، "الخراج بالضمان". المبدأ السادس: الاقتصاد الإسلامي، اقتصاد عادل لإل سمته الكبرى الإعلاء من شأن العدالة، وأن يكون

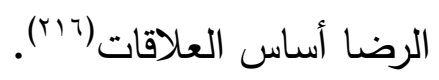

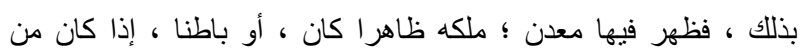

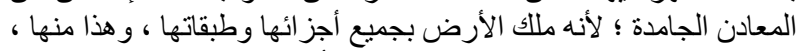

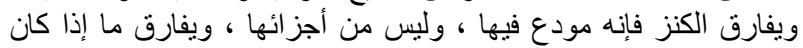

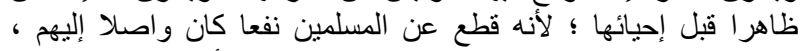

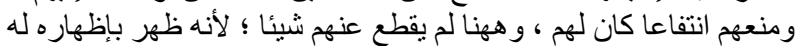

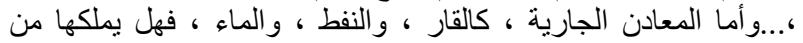

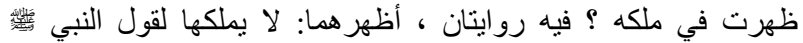

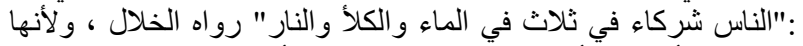

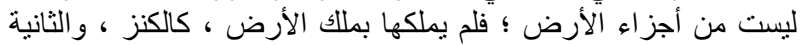

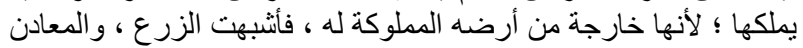

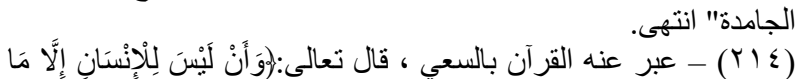

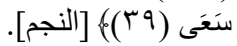

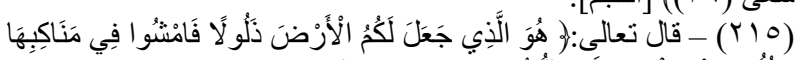

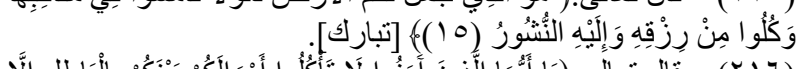

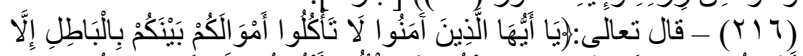

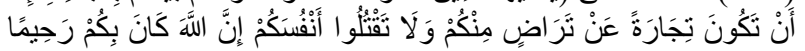

بسبب شرعي، وإذا وجدت كذلك، فإنها تكون محمية "محرمة"، ولا ترتبط بسقف، ولا تتتهك إلا بحق (rا'r).

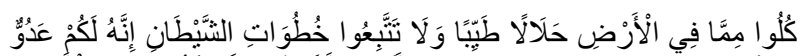

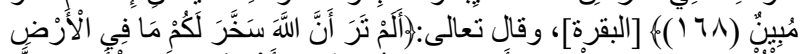

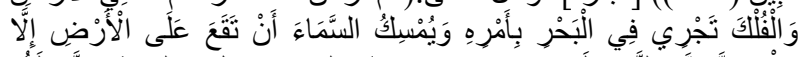

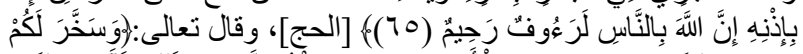

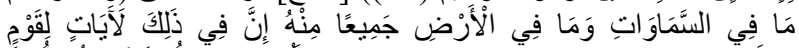

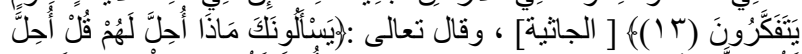

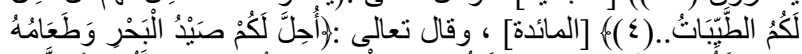

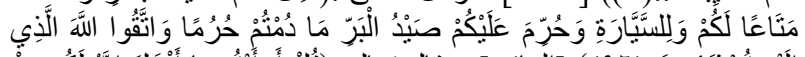

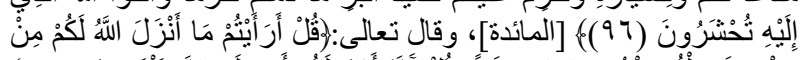

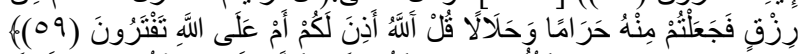

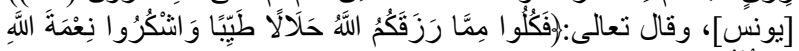

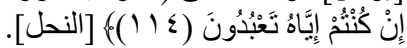

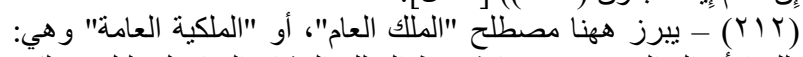

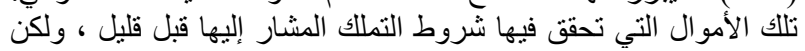

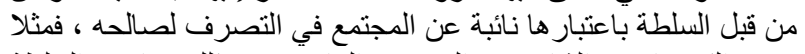

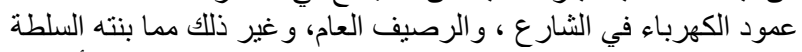

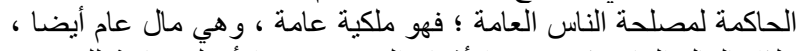

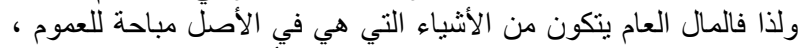

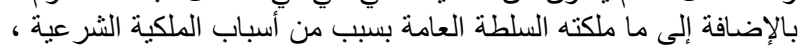

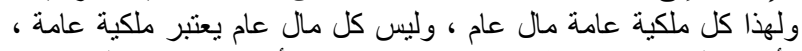

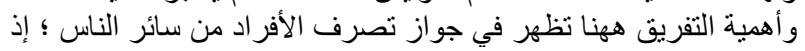

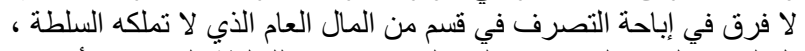

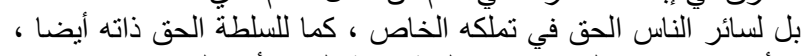

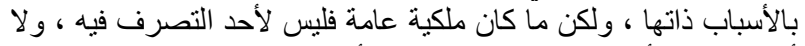

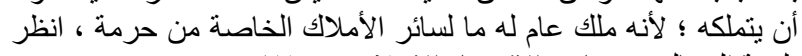

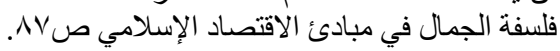

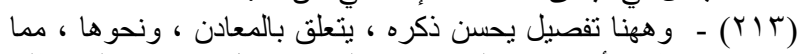

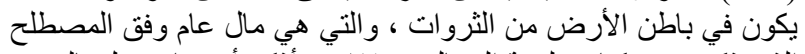

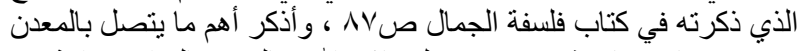

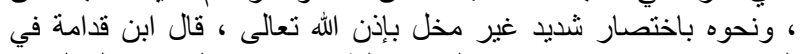

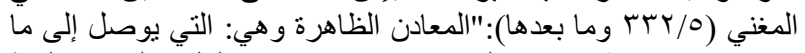

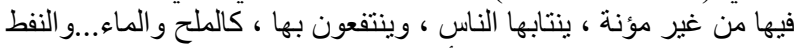

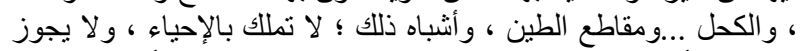

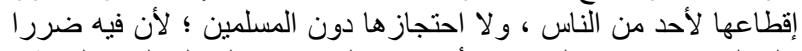

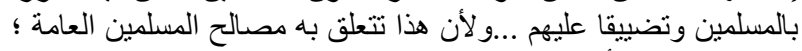

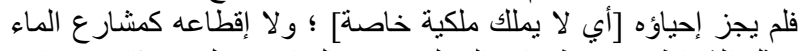

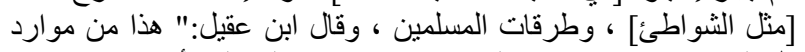

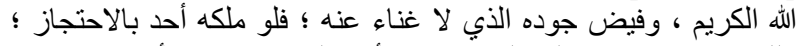

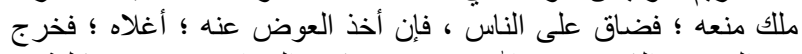

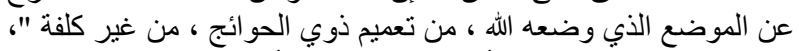

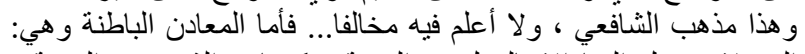

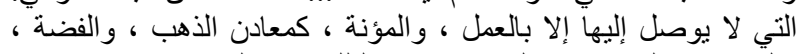

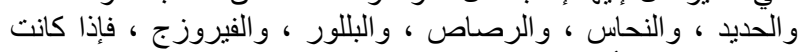

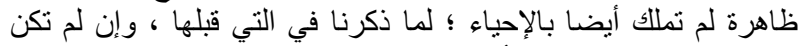

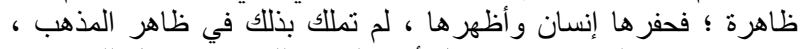

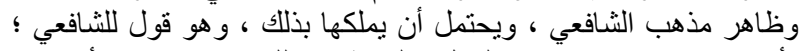

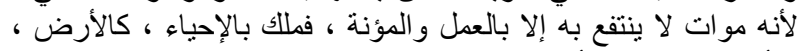

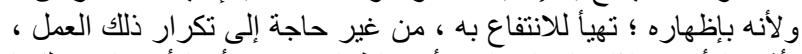

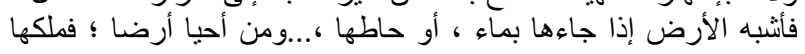


- اقتصاد الوفاء بالعقود، وتتفيذ الالتزامات ج- اقتصاد أداء الأمانة.

- اقتصاد القناعة وكف النفس عن الطمع. المبدأ الثاني عشر: الاقتصاد في الإسلام منضبط بقواعد الفقه الإسلامي بصفة عامة، فهو لم يكتف بالمبادئ بل وضع أحكاما تفصيلية، ومحددات لدى الأخذ بها تتحقق المقاصد الثرعية في الاقتصاد. بناء على تا سبق وما موقف الإسلام من الضريبة؟ الجواب سيأتي لاحقا، لدى بيان حكمها شرعا. غير أني أوكد أن الدارس المنصف لن يجد سببا لفرض الضريبة لو تم الأخذ بالمبادئ المذكورة آنفا، لأن تلك المبادئ كفيلة بتحقيق الرفاهية، بقوة الدفع الذاتية، وهي كفيلة بمقاومة كافة الأزمات. الفرع الثالث: أنواع الضرائب. تتعدد التصنيفات المتعلقة بالضريبة، بحسب الاعتبار الذي يتم توجيهها إليه، وبحسب النظام الذي يحكم العمل الاقتصادي، وأذكر أهم تصنيف في هذا الشأن باختصار، ثم أبين أي نوع يمكن أن يفرض على المهني، وقيود ذلك، ومدى إمكانية فرض ضرائب من قبيل ضريبة القيمة المضافة ونحوها. هذا ولدى النظر في المصادر التي تحدثت عن هذا الشأن، نجد أن أهم تصنيف للضرائب، ذلك أن التصنيف الذي يجعل منها ضرائب مباشرة، وأخرى غير المباشرة، وأبين كل نوع منها على النحو الآتي: أولا: الضرائب المباشرة: هي الضرائب التي لا يمكن نقل عبئها إلى شخص آخر؛ لأنها مرتبطة باسم
المبدأ السابع: الاقتصاد الإسلامي اقتصاد يؤمن بالتتوع، والاختلاف حتى حين يؤدي هذا التنوع إلى وجود طبقات اجتماعية متفاوتة، من الناحية

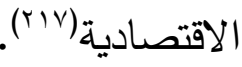
المبدأ الثامن: اقتصاد تكافلي لا حرمان فيه؛ أوجب الزكاة وحرم الربا وتحريم الربا مظهر تكافلي بالإضافة لكونه تمجيد للعمل والاستثمار، وتغليب للمصلحة العامة. المبدأ التاسع: اقتصاد المساواة حين لا يكون موجب للتفضيل فلا يجيز الامتيازات بدون حق. المبدأ العاشر : الاقتصاد في الإسلام يغلب المصلحة العامة على المصلحة الخاصة عندما يكون تعارض من كل وجه. المبدأ الحادي عشر: الاقتصاد الإسلامي اقتصاد أخلاقي: 1- اقتصاد لا يقبل الغرر أو الغبن الفاحش، وهو شيء لله أهميته الكبرى، بل لعله الأهم من حيث

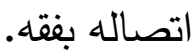
r- اقتصاد يوجب الصدق والشفافية. r- اقتصاد منصف لا يقبل بخس الناس أشياءهم.، كما أنه لم يضع حدا للربح ؛ وهما أمران مرتبطان؛ لأن البخس يقوم على أساس وضع حد للربح، أو للثمن في ذهنية المستهلك. ع- اقتصاد لا احتكار فيه.

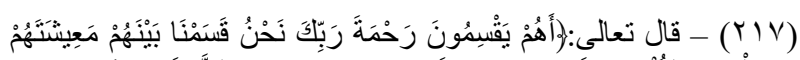

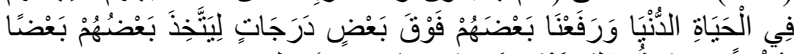

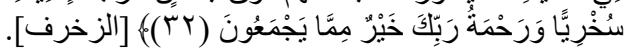


يذكر المتخصصون الاقتصاديون عدة منافع، وأهداف تتحقق بسبب الضريبة، وهم يعبرون عن ذلك من خلال ما يسمونه بوظائف الضريبة(rror)، وهذه يمكن إجمالها على النحو الآتي: 1- الوظيفة المالية: تحقق الضريبة ايرادات للخزينة

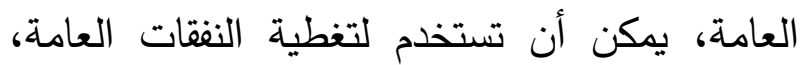
لمصلحة البنى التحتية، والخدمات، وغير ذلك.

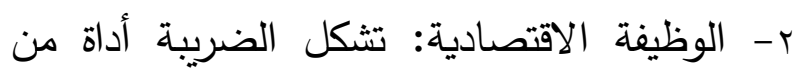

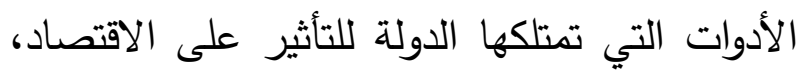

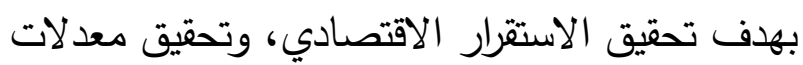

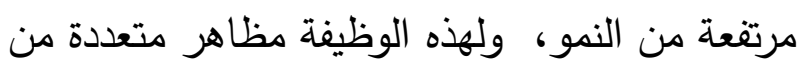
أهمها: أهرتة

أ- في حالة الانكماش: تكون في ظل هذه الحالة

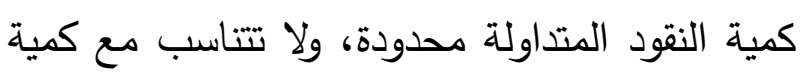
السلع، والخدمات المنتجة، والمعروضة للبيع، وفي هذه الحالة على الدولة زيادة إنفاقها لتعزيز كميات النقد، والحد من فرض ضرائب جديدة، بل عليها خفض المعدلات الضرببية، وزيادة الإعفاءات؛ صنئ بهدف أيجاد توازن جديد يعيد الأوضاع الاقتصادية

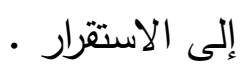

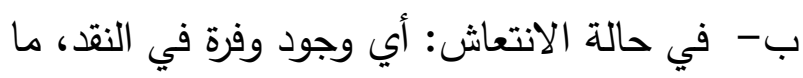

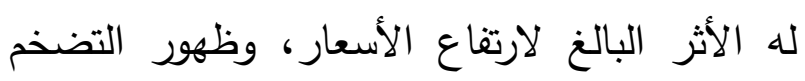

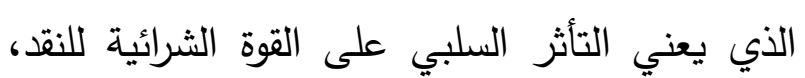

\%D9\%88\%D8\%A3\%D9\%87\%D8\%AF\%D8\%A7\%D9\%81\% D9\%87\%D8\%A7-\%D9\%88\%D8\%A7\%D9\%84\%D9\%82/

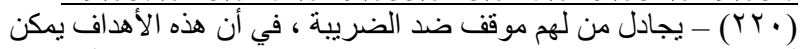

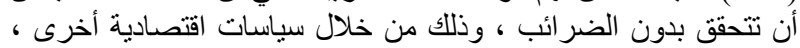
وسيأتي بيان شيء من هذا لاحقا.
الشخص حيث أن من يدفعها يتحملها بصفة نهائية، وتنقسم إلى: - الى - ضرائب رأسمالية: أي التي تتصب على رأس

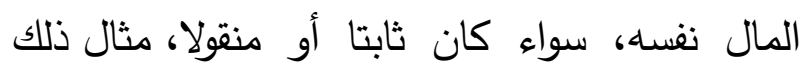
ضريبة التركات أو عقارات. ץ- ضرائب الدخل: أي فرض ضعرات ضريبة على الدخل الذي يحققه المكلف، نتيجة لمزاولة أوجه النشاط فرله

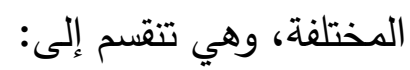

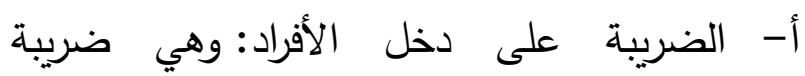
مصدرها العمل، أو العمل ورأس المال معاً. ب- الضريبة على دخل المؤسسات ونحوها: وهي ضريبة مصدرها رأس مال المنشأة. ثانيا: الضرائب غير المباشرة: تفرض هذه الضرائب

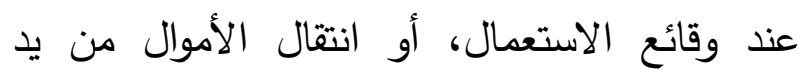

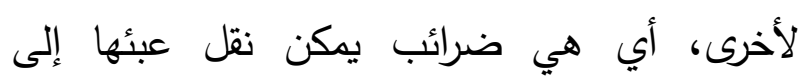
شخص آخر، فيقدر من يدفعها على نقل عبئها

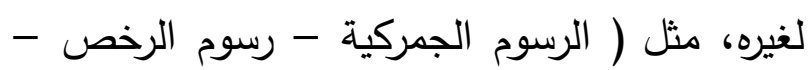
رسوم البريد - رسوم التليفون - والقيمة المضافة)

الفرع الثالث: وظائف الضريبة، وشروطها.

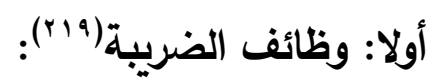

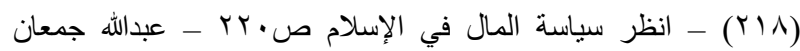

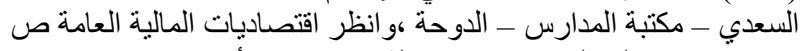

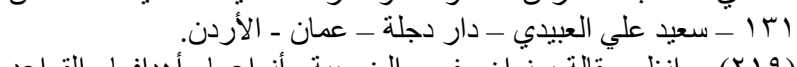

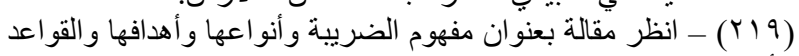

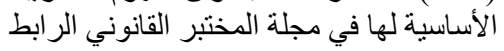
http://www.labodroit.com/\%D9\%85\%D9\%81\%D9\%87\%D9 $\% 88 \% \mathrm{D} 9 \% 85-$ \%D8\%A7\%D9\%84\%D8\%B6\%D8\%B1\%D9\%8A\%D8\%A8\% D8\%A9\%D9\%88\%D8\%A3\%D9\%86\%D9\%88\%D8\%A7\%D8\%B9\% 
الغنية، ففرض الضرببة على هذا النحو عليهح لا

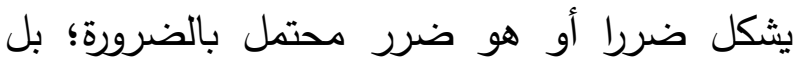
ستكون فرصة للمزيد من الدوران الاقتصادي، الذي هور بـرن يصب في نهاية المطاف في صالحهم، بوصفهر أرباب العمل، وبائعي السلع والخدمات المكتنزة بالربح والريوع الكبيرة، فتحققت لهم منافع بالإضافة ولهابة للمنافع المتحققة لغيرهم، وهكذا، فهم في الواقع تجار

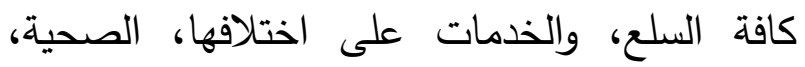
والتعليمية والاسكانية.

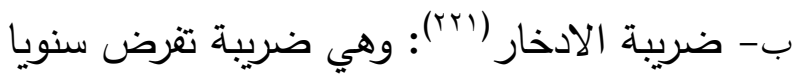

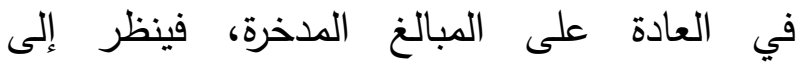
المدخرات، ثم تؤخذ منها الضريبة، فهذه الضريبة مرشحة للتهرب بامتياز لسهولة إخفاء المبالغ المدخرة، إذا لم تكن هنالك بنية تحتية جيدة تقنيا، وكان استعمال السيولة النقدية في التعاملات شائعا، فهي طبقا للتجارب في هذا الخصوص لها لهان آثار سلبية على الاقتصاد؛ لأنها تجعل المكلفين حريصين هاني

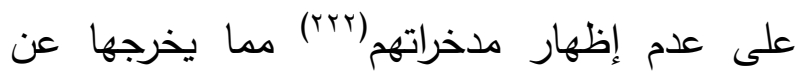
دورتها الاقتصادية، من ينعكس سلبا على الاقتصاد معرداد ككل.

ت- ضرائب الأصول غير العاملة: وهي تفرض عادة على أصول ذات قيمة عالية، تم تعطيل المنافع

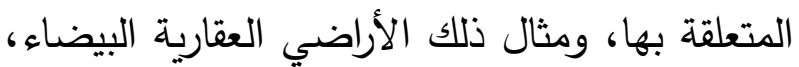

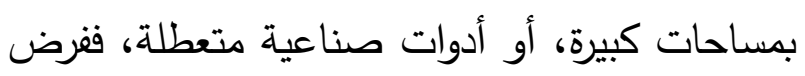

(YY) ليست منلها بالتأكيد ، وسياتني مزيد بيد بيان.

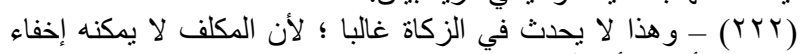
مدخر اته أبدا ، لأن الله لا تخفى عليه خافية.
فيتم حينها فرض الضرائب وبطرق مختلفة، ومن ضدنها فرض ضرائب على الاستهلاك مثلا، من أجل تقليص الوفرة في النقد ؛ وهذا له أثره في إعادة التوازن للاقتصاد. ت- حماية الإنتاج الوطني: إن قيمة الضريبة

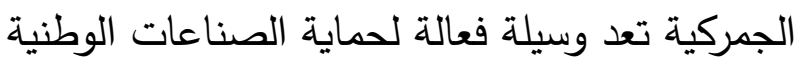
؛ لأن فرض الرسم الجمركي على السلع المستوردة سيؤدي إلى رفع ثنها، وبالتالي تفقد هذه السلع المستوردة مقدارا معينا من قدرتها التتافسية، ما يفسح المجال للمنتج الوطني ما له الأثر البالغ في أيجاد فرص استثمارية جيدة وبالتالي فرص عمل جديدة، ونحو ذلك، وهذا له أثره في نمو الاقتصادي. ث- الإعفاءات الضريبية: إن إعفاء بعض المشاريع

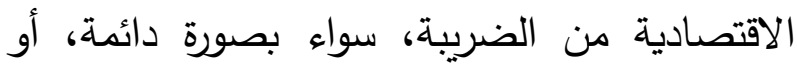
مؤقتة يسهم في تعزيز الصناعة المحلية، وتوجيه المستثمرون إلى مشاريع اقتصادية تحتاجها البلاد.

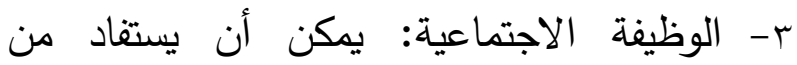

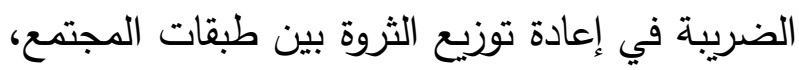
فمثلا: أ- ضريبة الدخل: وهي تثرض سنويا في العادة على أية مبالغ تدخل على الشخص الطبيعي أو لون الاعتباري، وتعتبر هذه الضريبة وسيلة فعالة لإعادة

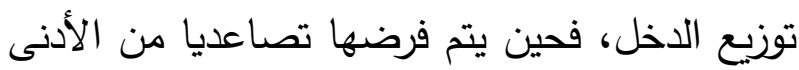

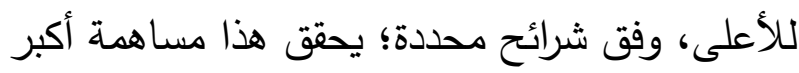
من الطبقة الغنية، لمصلحة الطبقات الأقل حظا، الذين هم في الأساس مصدر كثير من ثروة الطبقة 
الجهات التنفيذية وضع الأدوات التي تمكن من تطبيق هذا الشرط.

r. قاعدة اليقين ( الوضوح، والدقة): فلا يكون فيها غموض ؛ يجعل تتفيذها، وفهها عسيرا، من قبل المكلفين والجهات التنفيذية، لا زمانيا ولا كميا ؛ فلا تكون عرضة للتأويل والتقسير • r. قاعدة الملاءمة: فيكون وقت تحصيلها مناسبا

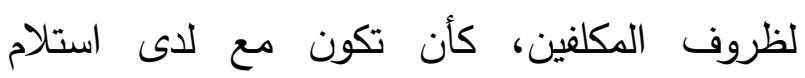
الرواتب، أو صدور الميزانيات في الثركات

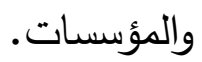

ـ. قاعدة الاقتصاد ( مبدأ الإنتاجية): أي أن يكون هناك اقتصاد في نفقات تحصيل الضريبة حيث تفضل الضرائب القليلة في نفقات التحصيل عن الضرائب المرتفعة في نفقات التحصيل. ه. قاعدة المرونة:أي أن تكون هناك علاقة طردية بين الدخل القومي، وحصيلة الضرائب ؛ لتتغير بتغير الظروف الاقتصادية، ولا يكون تحصيلها غاية

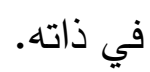
7. قاعدة الاستقرار: أي أن تتسم أحكام النظام

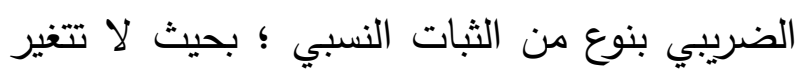

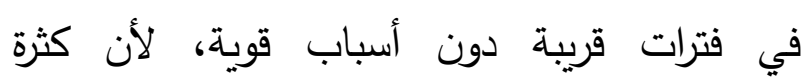
التعديلات تضعف من قاعدة اليقين. V. قاعدة التتسيق بين الأهداف:أي ألا تتعارض لصفئ.

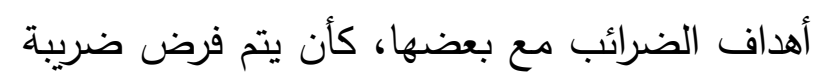

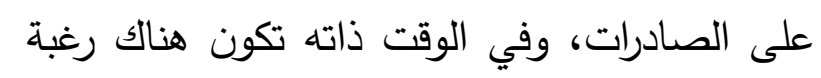

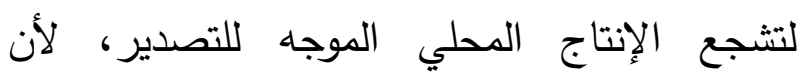

الضرائب على ذلك يحمل أصحابها على استغلالها واستثمارها، ما له الأثر البالغ في تتشيط الدورة

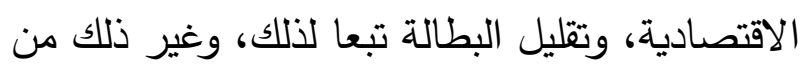

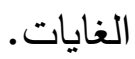

\section{ثانيا: قواعدها أو شروطهات(rrr).}

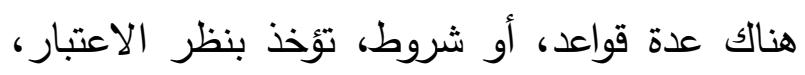

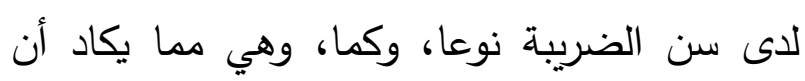

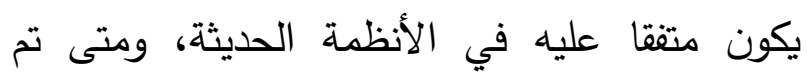
تجاهل أي من تلك القواعد ؛ يعتبر ذلك خلا ينبغ التهي تلافيه، وتلك القواعد هي: ا. ـ قاعدة العدالة ( قاعدة المساواة ) أو( العمومية) :أي أن الضريبة تتناسب مقدرة المكلف، بحيث:

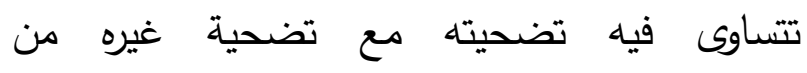
الخاضعين للضريبة. ويتم ذلك بتطبيق: أ- العدالة الأفقية :تعني معاملة المكلفين المتثابهين في الظروف معاملة متثابهة. ب- العدالة الرأسية :تعني معاملة المكلفين المختلفين

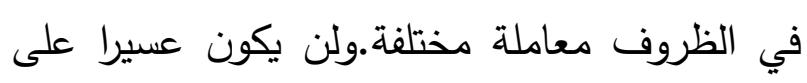

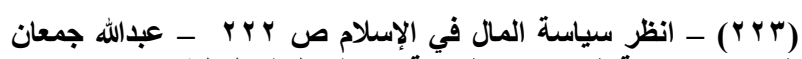

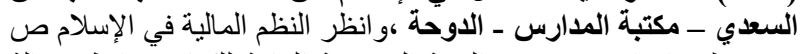

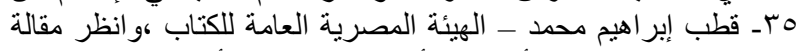
بعنوان مفهوم الضريبة وأنو اعها و أهدافها و القو اعد الأساسية لها في لهي مجلة

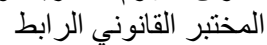
http://www.labodroit.com/\%D9\%85\%D9\%81\%D9\%87\%D9 $\% 88 \% \mathrm{D} 9 \% 85$ \%D8\%A7\%D9\%84\%D8\%B6\%D8\%B1\%D9\%8A\%D8\%A8\% D8\%A9\%D9\%88\%D8\%A3\%D9\%86\%D9\%88\%D8\%A7\%D8\%B9\% D9\%87\%D8\%A7\%D9\%88\%D8\%A3\%D9\%87\%D8\%AF\%D8\%A7\%D9\%81\% 
بين العلماء، والصحيح جوازه، قال الحافظ ابن حجر:" ذهب الجمهور إلى أنه حلال، واحتجوا بهذا

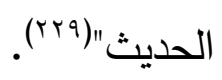

وأما الحديثان الآخران، فهما يتحدثان عن المبالغ التي يلزم الناس بدفعها من أجل التخلص من الأذى ؛ إذ كان شائعا في فترات كثيرة عبر التاريخ، أن يحدد أصحاب القوة، والنفوذ، مبالغ يفرضونها على الناس على حين ضعف من السلطة، من أجل كف الأذى عنهم، أو بسط حمايتهم لهم، فلا يعود على الناس نفع سوى كف أذى هؤلاء القوم، أو الاستعانة بهم لكف أذى آخرين، لا يخرجون عن سطوتهم، وهذه حماية قسرية، وليست تحمل لمسئوليات معلومة، ومحددة، وغالب من يفعل ذلك قطاع الطرق، والعصابات التي تمتهن الإجرام، فمن يدفع لهم يكفون عنها، ويمنحونه الحماية، لا عن سلطة عامة، وإنما هو فرض للقوة؛ هذا الذي يحرمه الإسلام، وهي المكوس المحرمة التي ذكرها علماؤنا

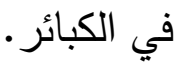
ولهذا لا نجد اختلافا بين المذاهب الأربعة، بشأن جواز فرض ضرائب على الناس، لجهة السلطة العامة؛ لقاء ما يعود بالنفع على الكافة، بشرط وجود حاجة لذلك، وذلك حين لا تفي مصادر الدولة للقيام بحاجات الناس، ويحملون أحاديث المنع على

$$
\text { ( ) - (rYq) }
$$

الضريبة على الصادرات تقلل حوافز الإنتاج المحلي الذي يستهدف السوق الخارجي. الفرع الرابع: حكم الضرببة شرعا. لم يرد لفظ الضريبة وما في معناها(؟rان) في القرآن الكريخ، وإنما ورد في السنة المطهرة(roro) في حديث أَنَسِ بن مَالَّكٍ رضي الله عنه قال حَجَمَ أبو طَيْبَةَ

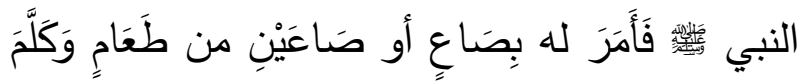

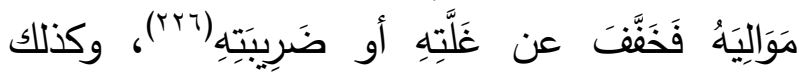
حديث رويفع بن ثابت: سمعت رسول الله صلى الله عليه وسلم يقول:" إن صاحب المكس في النار "(YYY)، النار "(rYr)، وكذلك عن عبد الله بن بريدة عن أبيه في رجم الغامدية التي ولدت من الزنا أن النبي صلى الله عليه وسلم قال :"والذي نفسي بيده لقد تابت توبة لو تابها صاحب مكس لغفر له"(r^). وهذان سياقان لا يتتاولان ما عنه نتحدث؛ لأن الحديث الأول يقرر: جواز أن يكلف الرجل عبده ؛ ليعمل على جلب مبالغ نقدية لجهة سيده، لأن السيد مسئول عن تأمين حياة كريمة لعبده، وهذا فيه خلاف

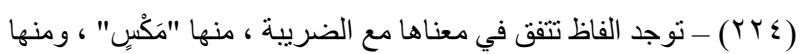

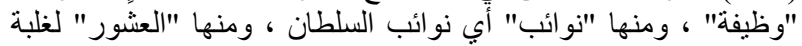

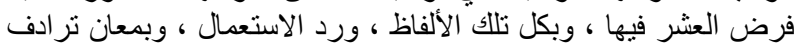
الضريبة ، وسياتتي سياق ذلك.

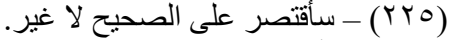

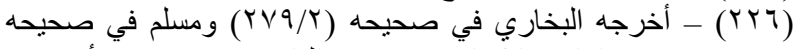

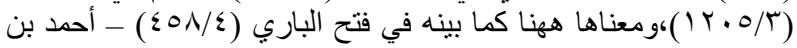

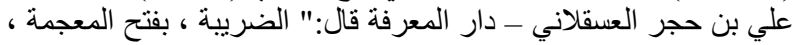

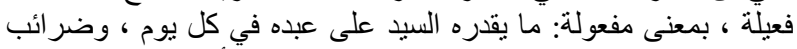

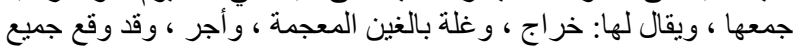

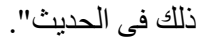

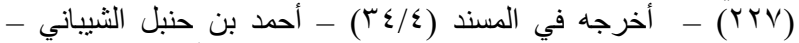

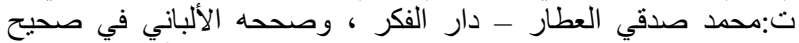
الترغيب و الترهيب برقم VAV - محمد ناصر الدين الألباني - مكتبة في لفي 
الخياط، والصباغ، وغيرهم للسلطان في كل يوم، أو

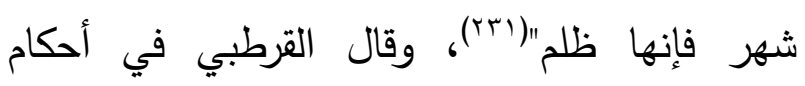
القرآن، وهو من أئمة المالكية، قال:" قوله تعالى:

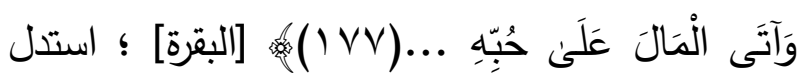
به من قال: إن في المال حقا سوى الزكاة، وبها كمال البر، وقيل المراد الزكاة المفروضة، والأول أصح ؛ ...فقد دل على صحته معنى ما في الآية

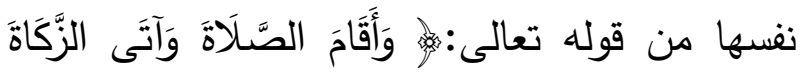

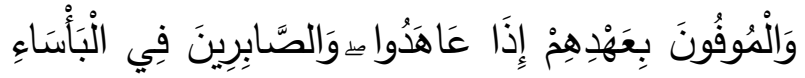

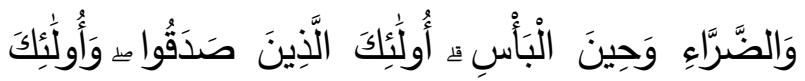

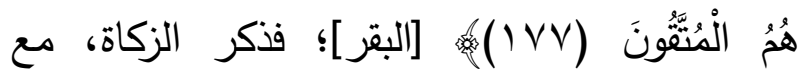

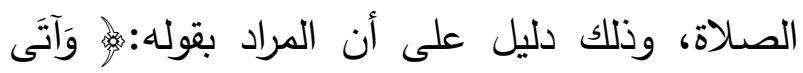
الَّْالَ عَلَئ حُبِّهِ ... (IVV) المفروضة، فإن ذلك يكون تكرارا، والله أعلم، واتفق لئه العلماء على أنه إذا نزلت بالمسلمين حاجة بعد أداء لكون

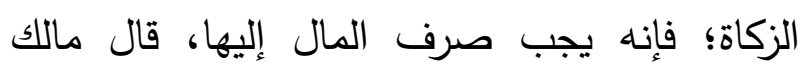

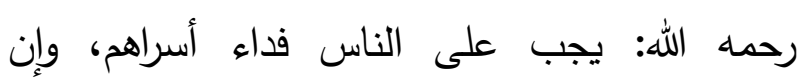
استغرق ذلك أموالهم، وهذا إجماع أيضا، وهو يقوي

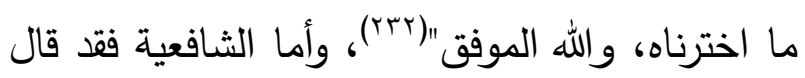
الغزالي في المستصفى:" إذا خلت الأيدي من الأموال [أي يد سلطان الوقت]، ولم يكن من مال المصالح

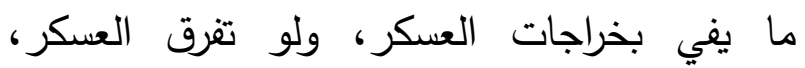

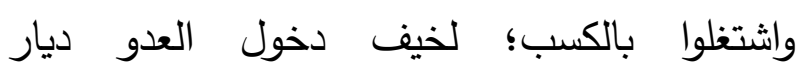

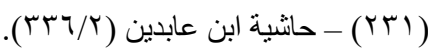

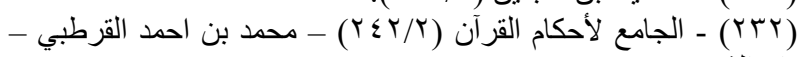

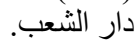

الوصف المذكور آنفا(·rr)، وفي هذا قال ابن عابدين في حاشيته، لاى الحديث عن جواز ضمان الضرائب الفائ

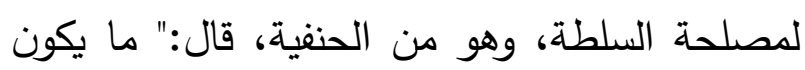
بحق ؛ كأجرة الحراس، وكرى النهر المشترك، والمال

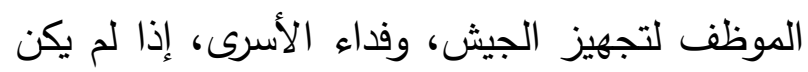

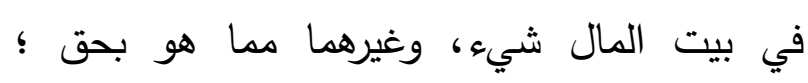

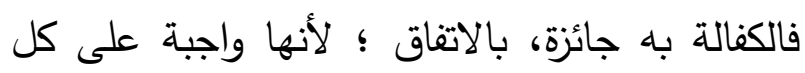

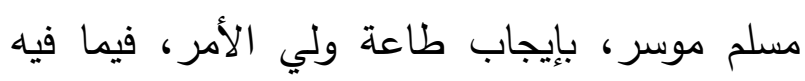

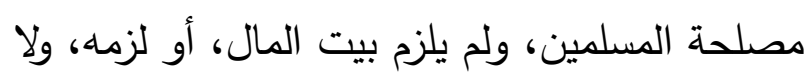
شيء فيه، وإن أريد بها ما ليس بحق، ولئ كالجبايات

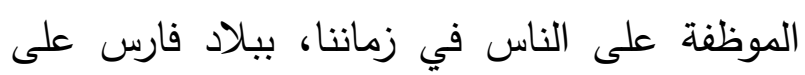

•

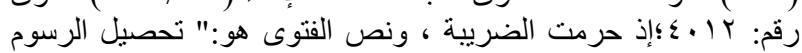

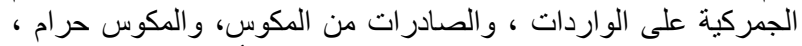

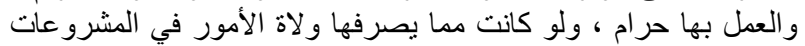

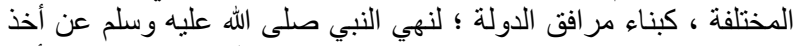

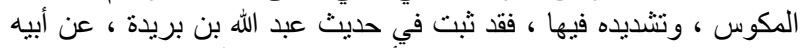

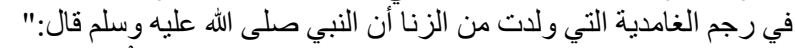

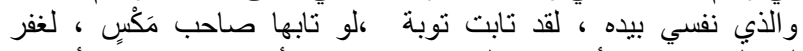

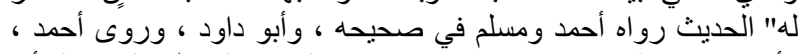

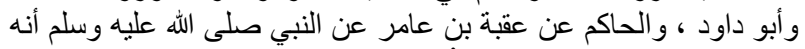

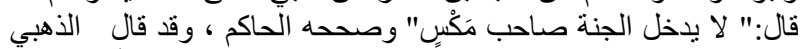

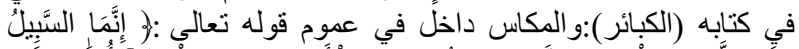

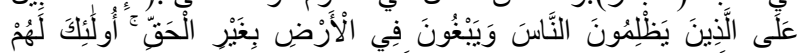

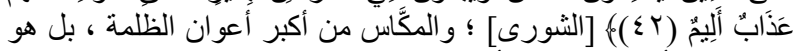

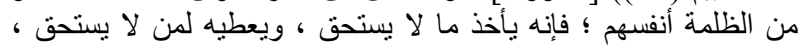

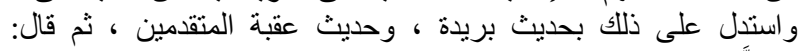

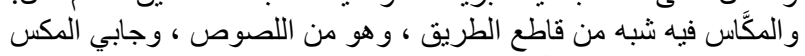

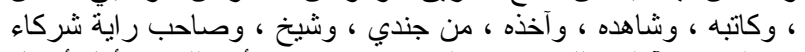

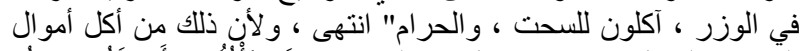

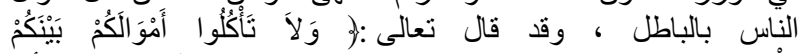

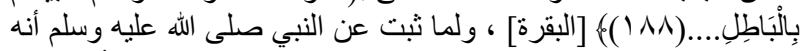

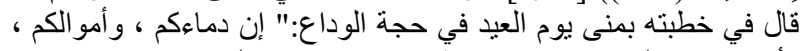

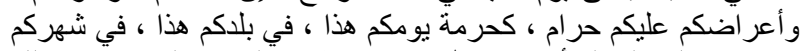

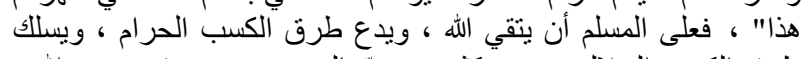

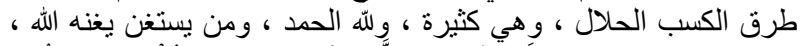

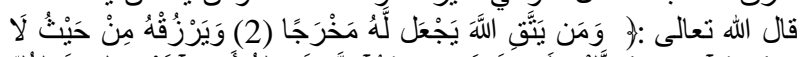

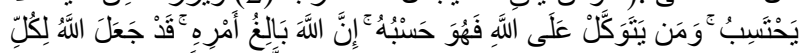

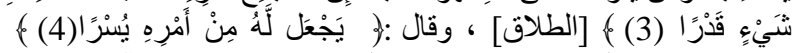

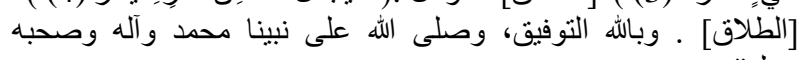


الواجبة، وكذلك الاعطاء في النائبة: مثل الجهاد في سبيل الله، واشباع الجائع، وكسوة العاري"(rra). وقد قرر ذلك ابن حزم، من الظاهرية بأتم بيان قال

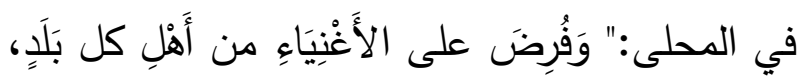

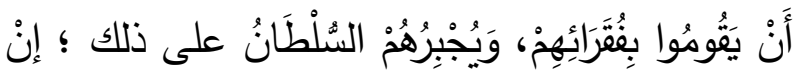

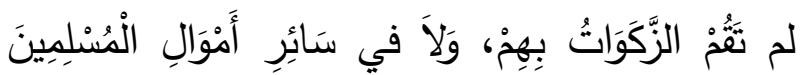

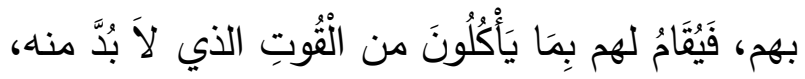

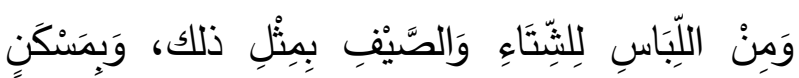

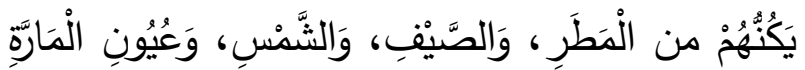

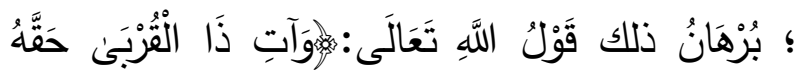

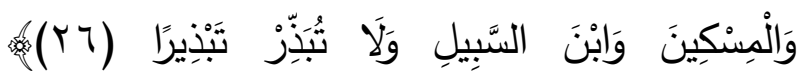

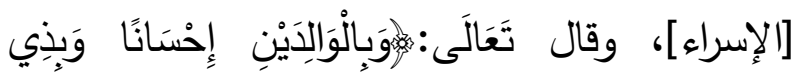

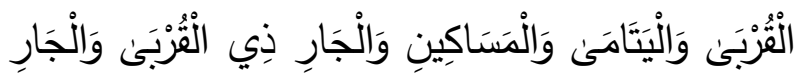

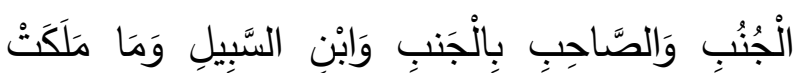

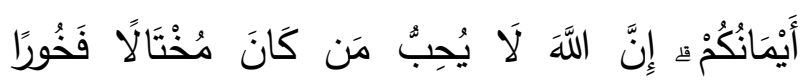

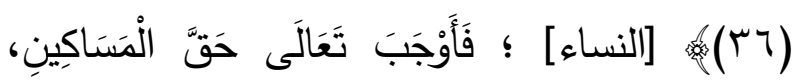

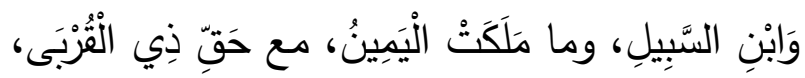

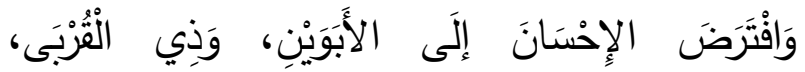

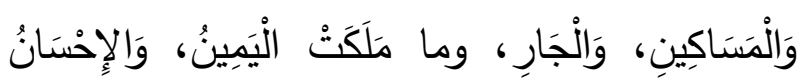

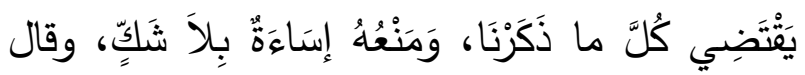

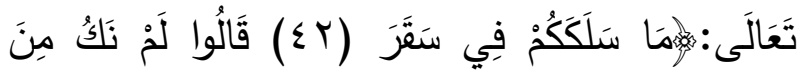

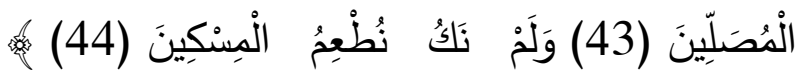

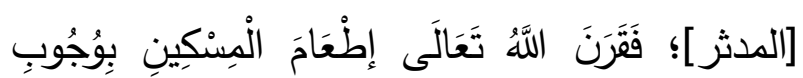

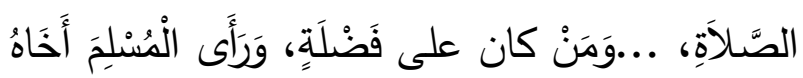

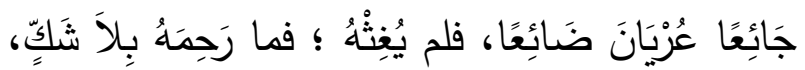

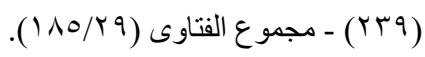

المسلمين، أو خيف ثوران الفتتة من أهل العرامة(YrT)

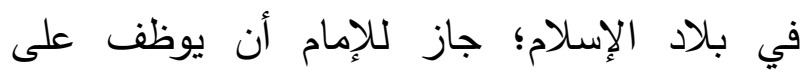

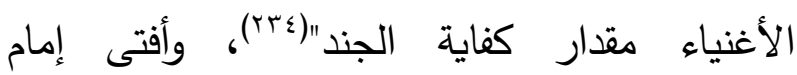
الثافعية العز الدين بن عبد السلام، الملك المظفر قطز، بجواز فرض الضرائب على الناس؛ لأجل

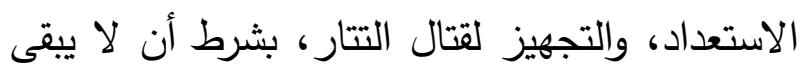

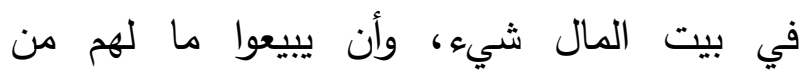

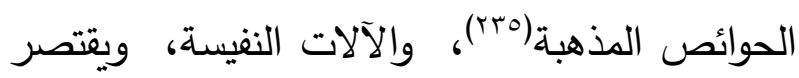

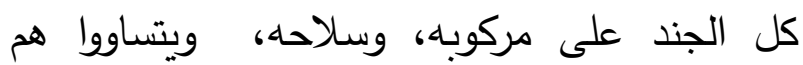

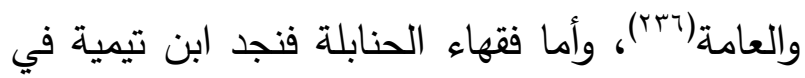
الفتاوى يقول:" وأما الزكاة ؛ فإنها تجب حقاء الله في ماله، ولهذا يقال: ليس في المال حق سوى الزكاة: أي ليس فيه حق يجب بسبب المال ؛ سوى الزكاة،

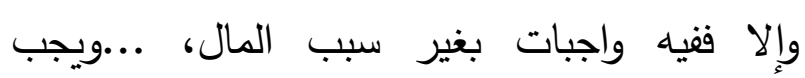

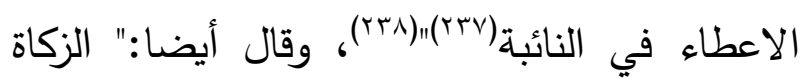
هي الواجب الراتب، التي تجب بسبب المال بمنزلة

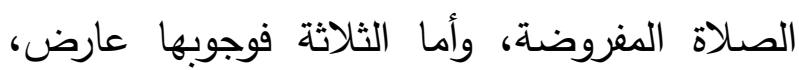
فقرى الضيف: واجب عندنا، ونص عليه الثافعي،

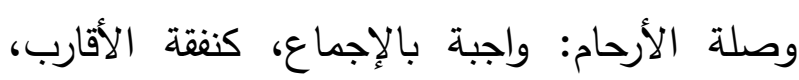
وحمل العاقلة، وعتق ذي الرحم: واجبه بالإعاع، المحرم، وإنما الاختلاف فيمن تجب صلته، وما مقدار الصلة

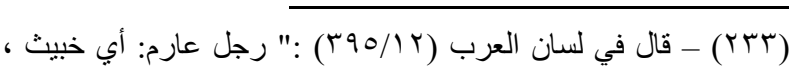
شرير ، و العر ام: ألثدة ، و القوة ، و والثراسة").

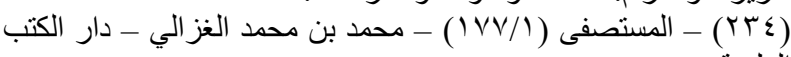

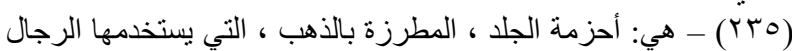

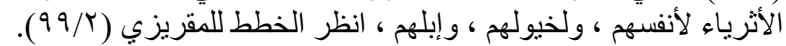
(YT)

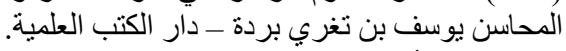

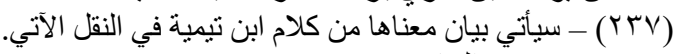
每 


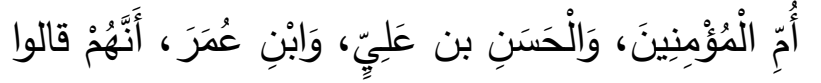

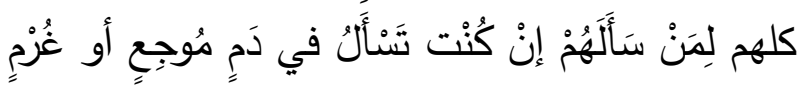

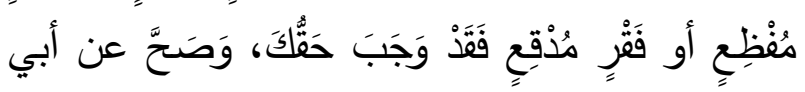

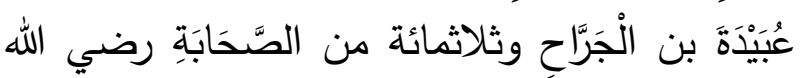

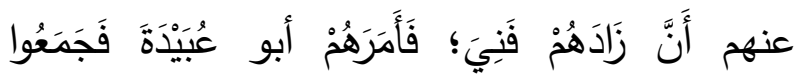

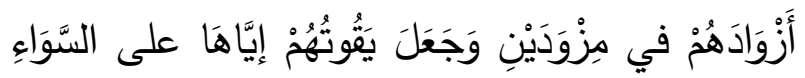

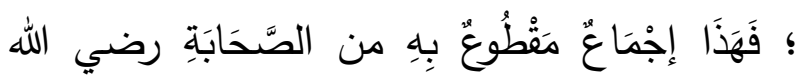

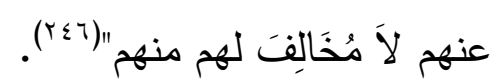
ما ذكر آنفا يقرر أن فرض الضرائب جائز بشروط أساسية:

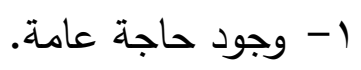
r- عدم كفاية الموارد المالية للدولة.

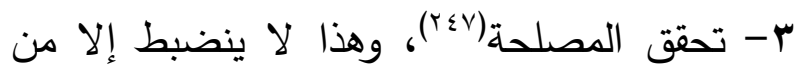
وجود موافقة من أهل الشورى، أو ما يسمى هذه الأيام بالبرلمان؛ لأن الأصل هو هو عصدة ألهان أموال الناس إلا بحق؛ وهو شيء قطعي معلوم من الدين الان الإنب

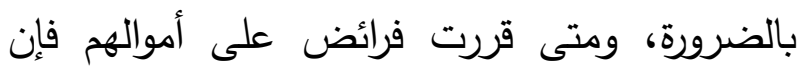

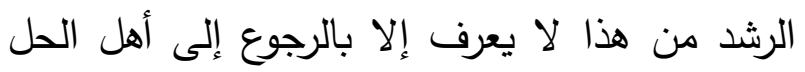

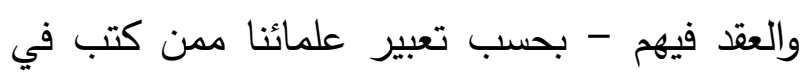
الأحكام السلطانية - وهم أهل الثورى أو البرلمان بحسب تعبيرنا هذه الأيام، والبحث في هذا ليطول وأكتفي بهذا القدر منه، ولمن أراد التوسع فله أن فئن

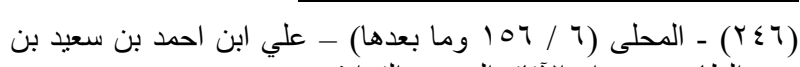
حزم الظاهري - دار الآفاق الجديدة. التراث (باث) (Y乏V)

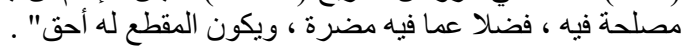

وَهَذَا خَبَرُ ...أَنَّ عَبْدَ الرحمن بن أبي بَكْرِ الصِّدِّيقِي

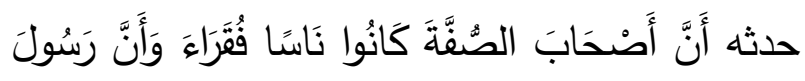

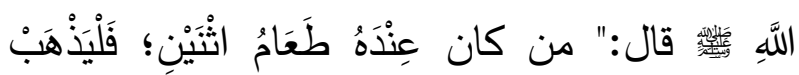

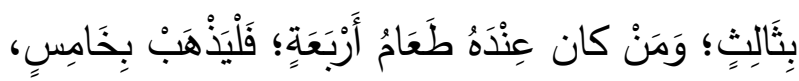

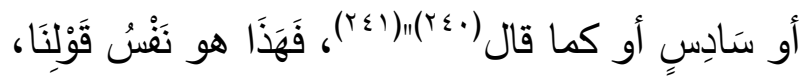

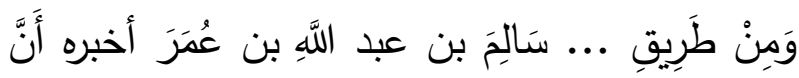

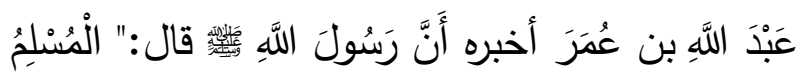

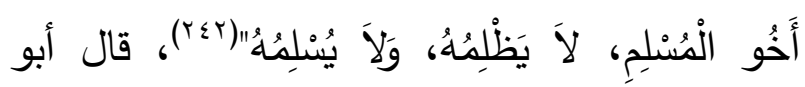

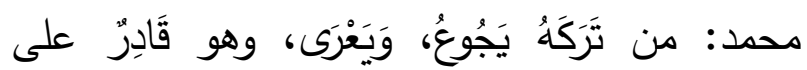

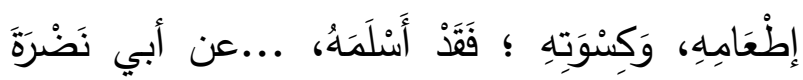

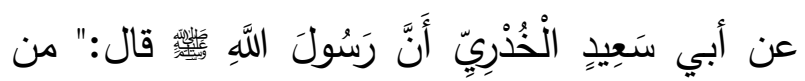

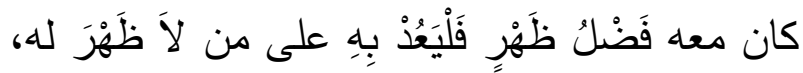

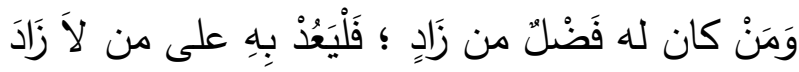

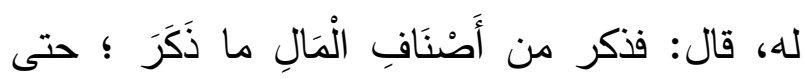

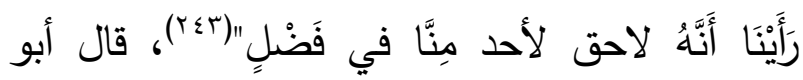

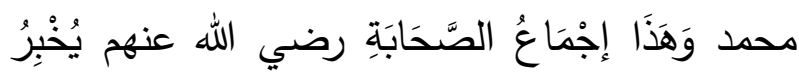

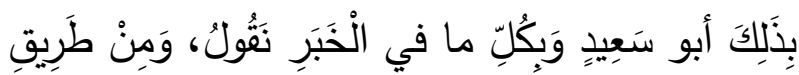

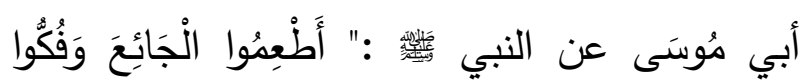

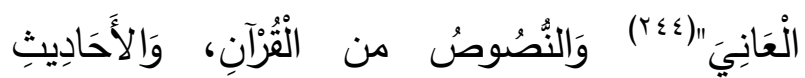

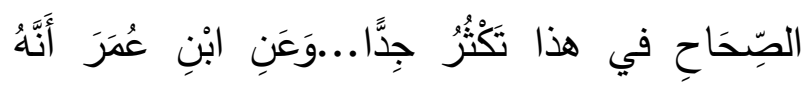

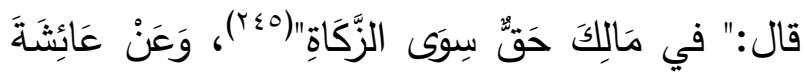

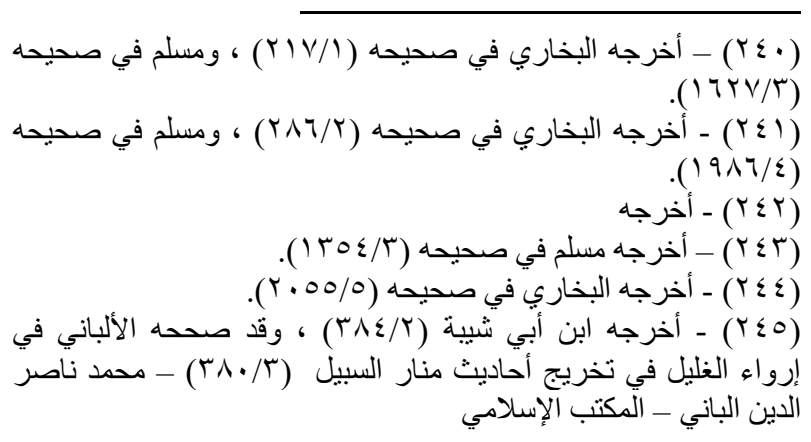


يقبل شرعا، أو عقلا، أن تفرض على المهني ضريبة لا تفرض على من يماثله، فمثلا لو تم تطبيق ضريبة القيمة المضافة، على المهني، فئل فإنها

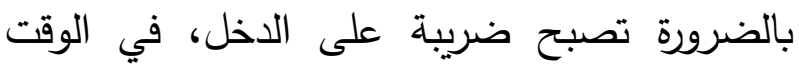
الذي لا تغرض ضريبة دخل على الآخرين ؛ لأنه وبالضرورة العقلية ؛ أية ضرائب تفرض على الته المهني هي ضرائب مفروضة على دخله، وهي لا تتثبه

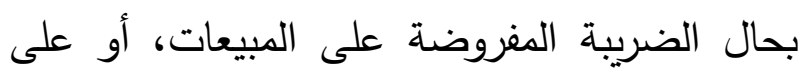
الاستهلاك، أو نحو ذلك، فليس عدلا تحميل المهني

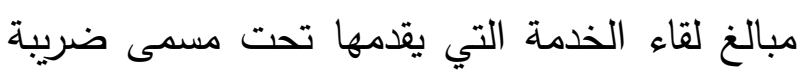
القيمة المضافة؛ لأن ما يأخذه عائد الجها الذي بذله فئل

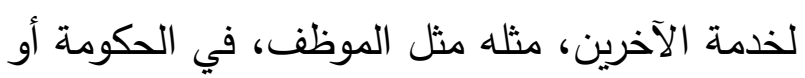

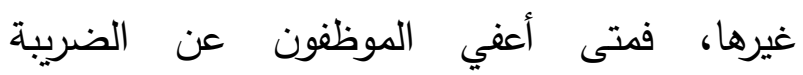
فبالضرورة يصبح من حق المهني الإعفاء ذاته، فكلاهما يتقاضى مقابل الخدمة التي يبذلها للآخرين، وما ينالونه جميعا هو ثمرة جهابهم المباشر، وهو لأليان مهما بلغ لا يزال مرتبطا بمقدار ما يبذلانه من جهد،

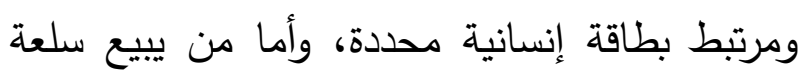
فهو يدفع الضريبة بتوسط شيء آخر، والعائد منه لا لا

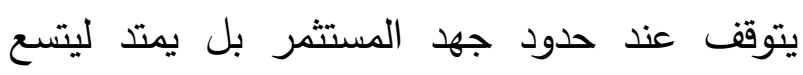
للخول مجهودات أخرى متراكمة تحقق العوائد الكبيرة؛ فالتعويض يتم بواسطة سلعة يتم تداولها

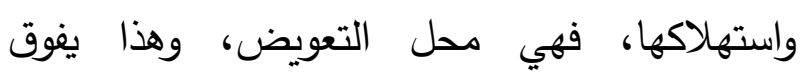

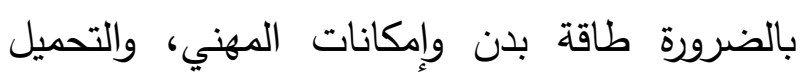
على بدنه لا على سلعة يبيعها، والسلعة يمكن أن الن النيان تمتد العوائد المتحققة منها امتداد كبيرا.
يرجع إلى مؤلفات عدة حررت في هذا

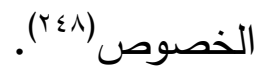

الفرع الخامس: وكيف ينبغي أن تكون الضريبة على المهني باعتبارها بديلا للزكاة.

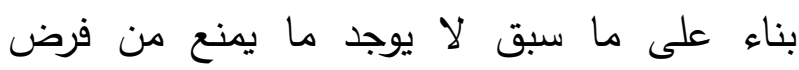

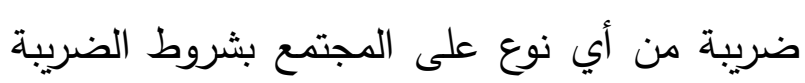

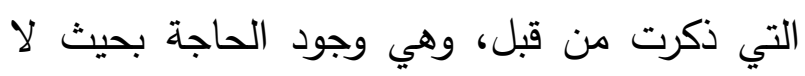

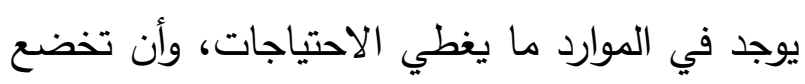
لقرار يصدر عن هيئة تشريعية كمجلس نواب أو الواتيات مجلس شورى غايتها رعاية مصالح الناس، ولها دور في مراقبة أوجه الإنفاق وتراقب حسن التنفيذ، وهذا لو توفر سيكون محل قبول الكافة، وسيكون عادلا بالضرورة، وقد أسلفت بييان حكم الثرع في هذا من عن

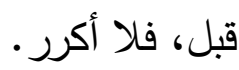
غير أننا ولاى النظر في شروط الضريبة وقواعدها التي سبق ذكرها، نجد منها قاعدة العدالة (قاعدة المساواة) أو (العومية) وهي تعني عدالة أفقية: تعني معاملة المكلفين المتشابهين في الظروف معاملة الطية مثشابهة، وعدالة رأسية: تعني معاملة الدكلفين المختلفين في الظروف معاملة مختلفة، ولن يكون عسيرا على الجهات التتفيذية، وضع الأدوات التي

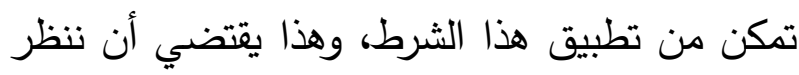
إلى الضريبة التي تفرض على المهني ؛ فلا تكون مفروضة عليه على نحو ينتقر إلى العدالة، إذ لا لا لئان

(Y乏^)

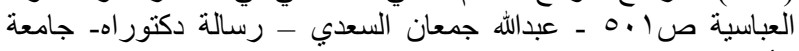
الأزهرك، 


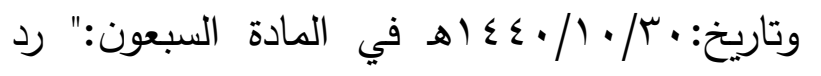
الضريبة إلى الأشخاص المعينين 1-دون الإخلال بالاتفاقية والنظام، للهيئة أن تسمح الإنين

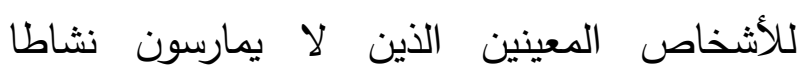
اقتصاديا أو الذين يعملون في نشاط اقتصادين لادين معين، تقديم طلب استرداد الضرائب التي يسددونها

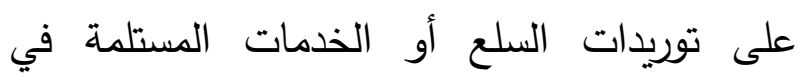
المملكة، ولوزير المالية أن يصدر من وقت لأخر الخر قائمة بأسماء الأشخاص المؤهلين لاسترداد الضريبة،

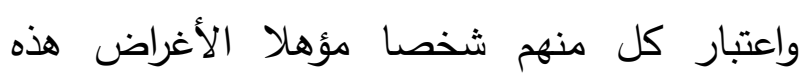

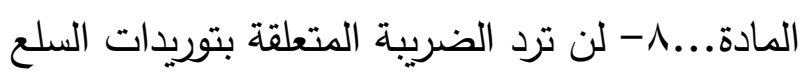

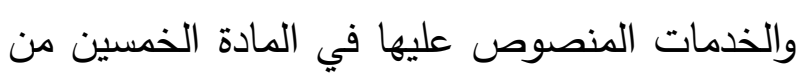
هذه اللائحة والتي لم يتم تكبدها في سياق ممارسة

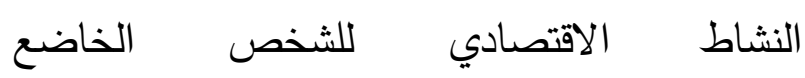
للضربية..."انتهى. ذكرت المادة فئتين يجوز لهما طلب الاسترداد، وهما: 1- من يحددهم وزير المالية، في حالة أن لم يكن

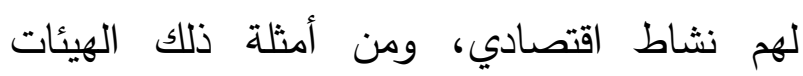
الأجنبية ونحو ذلك مما يستثنيه وزير المالية.

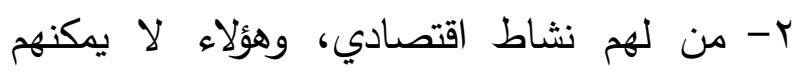
الاسترداد، إلا في سياق ممارسة النشاط الاقتصادي لإهاء

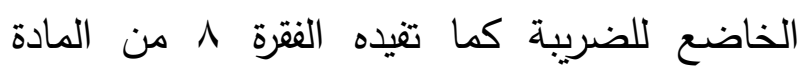
سبعين أعلاه.

ولما كان المهني لا يكاد يشتري لمصلحة مهنته شيئا

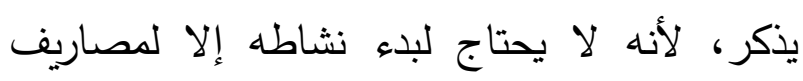

لكل ما سبق، وللحفاظ على قاعدة العدالة في فرض

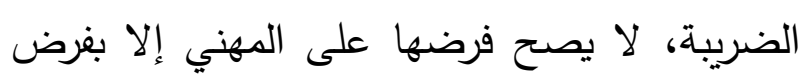

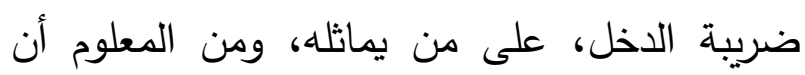

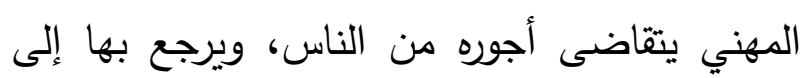

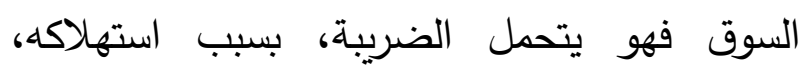
كسائر الناس، في الوقت الذي لا يجد وسيلة ناجعة

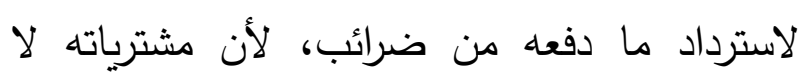
ترتبط بعمله غالبا، ما يجعله ضحية للازدواج

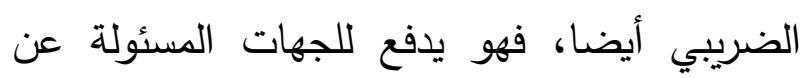

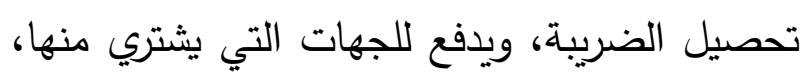
ما يوقعه بالضرورة في الازدواج الضريبي ؛لأن الوعاء في الحالتين هو جهده، فليس سائغا أن نسمي بلفي ما يدفعه حالتئذ بضريبة القيمة المضافة، لأن القواعد التهاء القانونية الخاصة بضريبة القيمة المضافة، تمنح الحق في استرداد الضريبة التي دفعها من الوعاء الضريبي الذي سيدفعه، بشرط أن يكون الوعاء

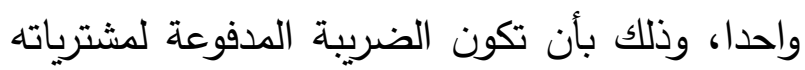
أكثر من الضريبة المدفوعة لمبيعاته، فعندها يصبح

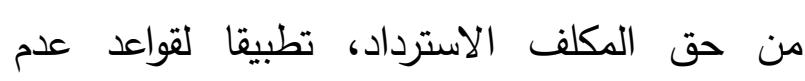
الازدواج الضريبي، ونصت اللائحة التنفيذية لنظام ضريبة القيمة المضافة الصادرة بموجب قرار مجلس ونس الهردي

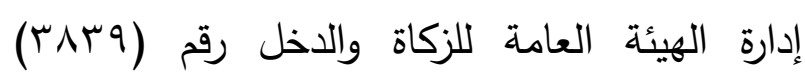

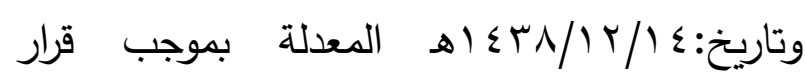

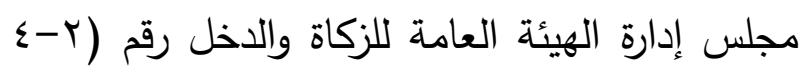

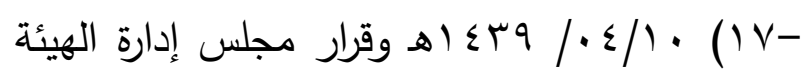

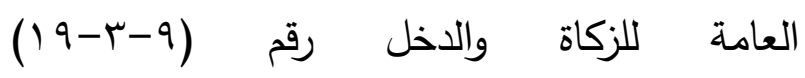




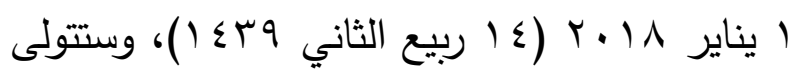

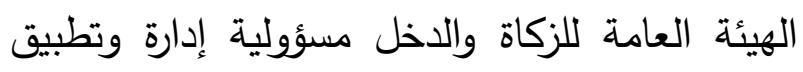
ضريبة القيمة المضافة في المملكة العربية السعودية،

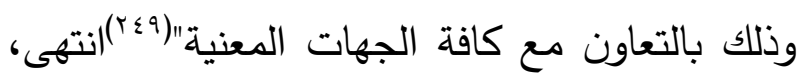

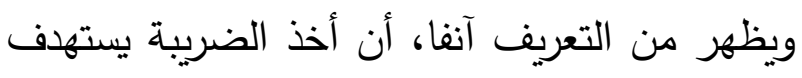

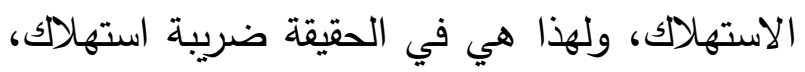

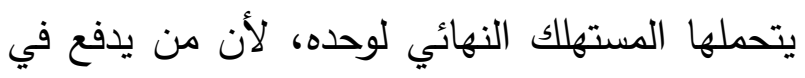

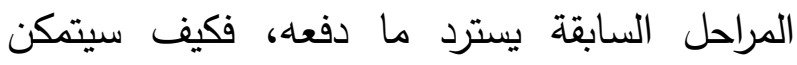

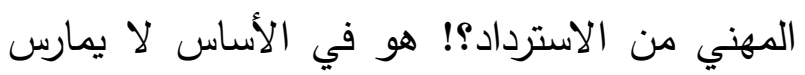

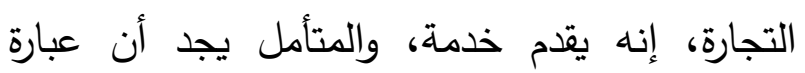

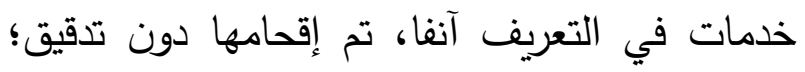

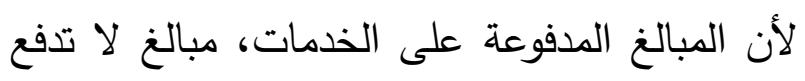

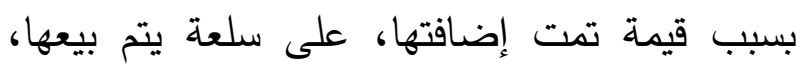

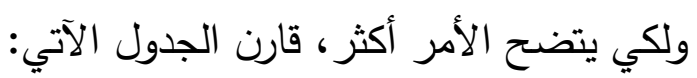

https://gazt.gov.sa/ar/RulesRegulations/VAT/Pages/Abo
التأسيس، وأما مصاريفه للتشغيل فلا يؤبه لها، وعليه

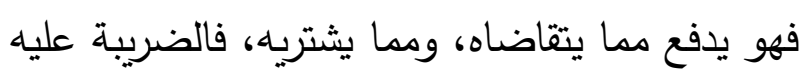

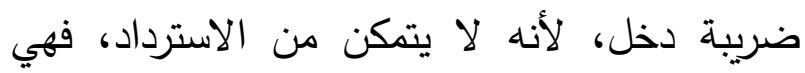

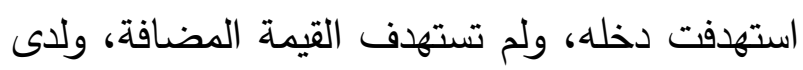
النظر في تعريف القيمة المضافة المبين في موقع هيئة الزكاة والدخل، نجد أنها:"ضريبة غير مباشرة تُفرض على جميع السلع والخدمات التي يتم شراؤها

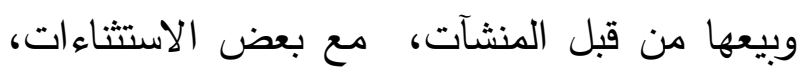
وتُطبق ضريبة القيمة المضافة في أكثر من . 17

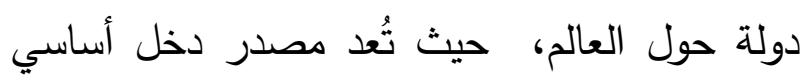

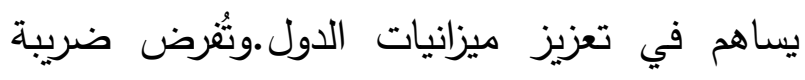
القيمة المضافة في كل مرحلة من مراحل سلسلة

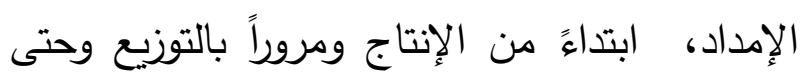

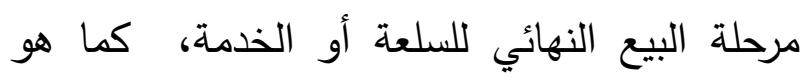
موضح أدناه؛ ويدفع المستهلك تكلفة ضريبة القيمة المضافة على السلع والخدمات التي يشتريها، أما المنشآت فتدفع للحكومة ضرببة القيمة المضافة التي يتم تحصيلها من عمليات شراء المستهلكين، وتسترد

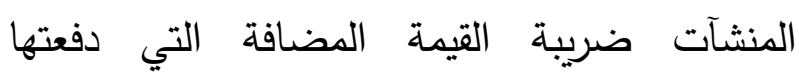

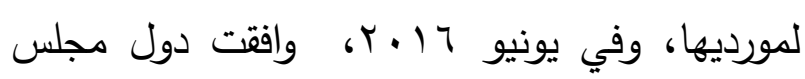
التعاون الخليجي على اعتماد ضريبة القيمة المضافة ولئ دوني

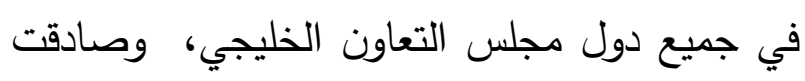
المملكة العربية السعودية على الاتفاقية الموحدة لهنية

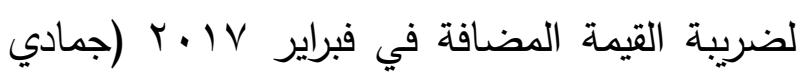

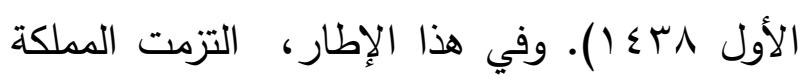

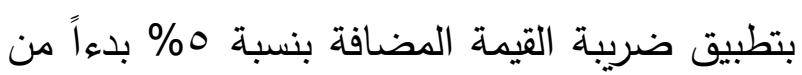




\begin{tabular}{|c|c|c|c|c|c|c|c|c|}
\hline الصافي & الاسترداد & مشتريات & تاجر ملابس & الاسترداد & 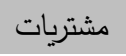 & محامي - طبيب - مستشار مالي & & الشخص \\
\hline \multirow[t]{2}{*}{1000} & 4000 & 80000 & 100000 & 0 & 0 & 100000 & المبيعات & 1 \\
\hline & & 4000 & 5000 & & & 5000 & الضريبة & \\
\hline \multirow[t]{2}{*}{1000} & 3000 & 60000 & 80000 & 0 & 0 & 80000 & المبيعات & 2 \\
\hline & & 3000 & 4000 & & & 4000 & الضريبة & \\
\hline \multirow[t]{2}{*}{1000} & 2000 & 40000 & 60000 & 0 & 0 & 60000 & المبيعات & 3 \\
\hline & & 2000 & 3000 & & & 3000 & الضريبة & \\
\hline 1000 & 1000 & 20000 & 40000 & 0 & 0 & 40000 & المبيعات & 4 \\
\hline 2000 & & & 2000 & & & 2000 & الضريبة & \\
\hline 6000 & & & & & 14000 & & 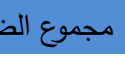 & \\
\hline
\end{tabular}

هذا الجدول يوضح على نحو تقريبي، بل فيه قدر اليها السلعة، لأنه يسترد ما دفعه للمرحلة التي تسبق

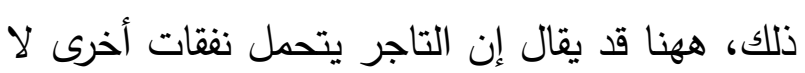

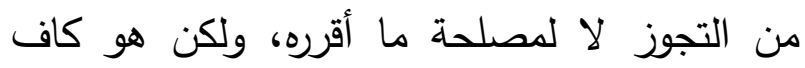

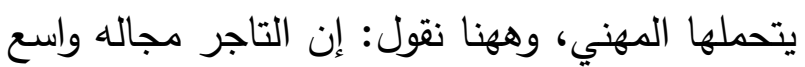

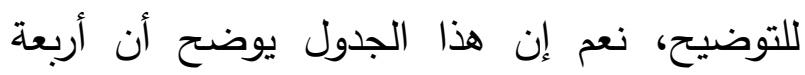

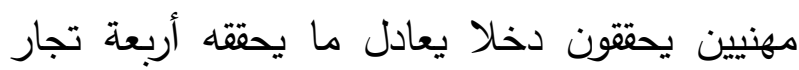

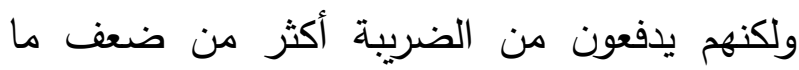

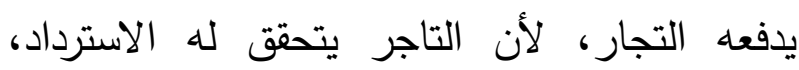

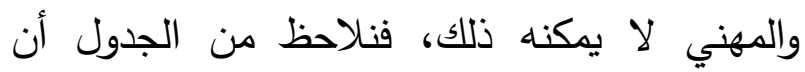
التاجر رقم (1) حقق مبيعات بمائة الف، ودفن لهن ضريبة 0\% وهو اشترى من تاجر قبله بمبلغ ثمانين ألفا، فمن حقه استرداد الضريبة المدفوعة لهذا التاجر

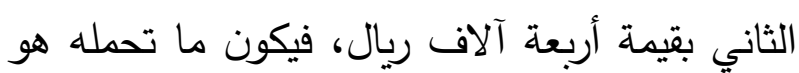
ألف ريال فقط، وهكذا في باقي المراحل كما واضح (Y0.) - نعم هناك نظام ضريبة للاذل عندانا ، وهو الصادر بالمرسوم

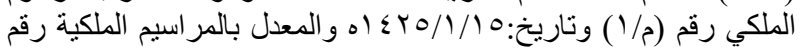

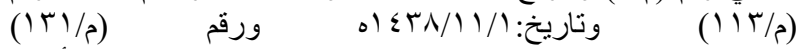

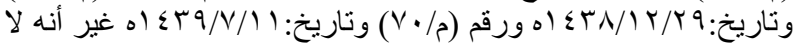

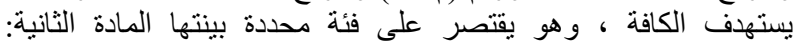

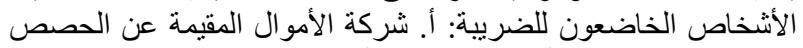

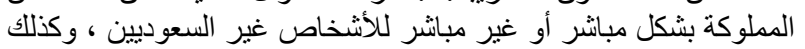

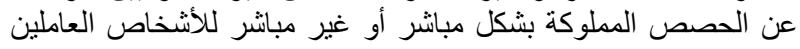

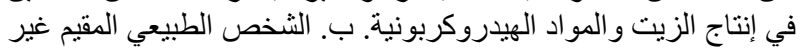

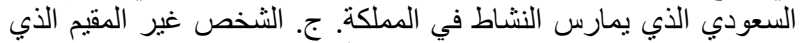

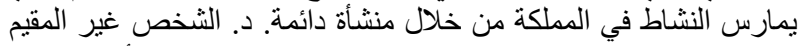

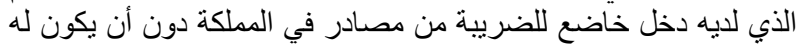

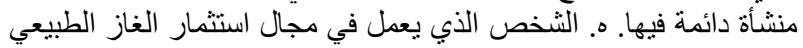
في الجدول، فكأن كل تاجر دفع ضريبة تعادل المبلغ

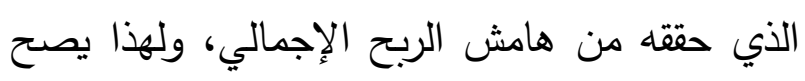

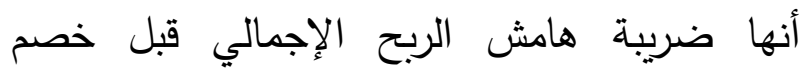
المصاريف العمومية والإدارية، وهذا يفسر القيمة

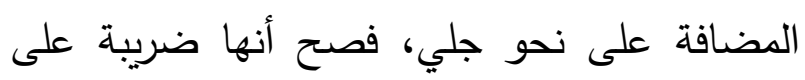

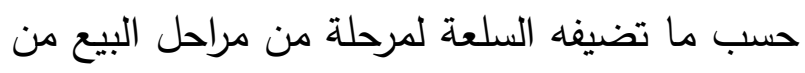

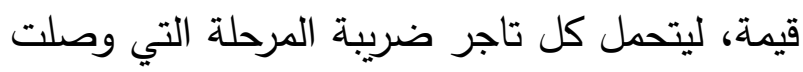


نوعها، وطريقة تحصيلها، فقد تحفز الاستثمار، وقد تحبطه، وقد تقيد الاقتصاد، وقد تضره، وقد تزيد البطالة وقد تقللها، وقد تزيد التضخم، وقد تضبطه. ج- الزكاة تبذل بدافع الرقابة الذاتية بصفة أساسية ؛ فيدفعها المكلف من تلقاء نفسه بافتراض عدم طلب الحكومة، الضريبة تبذل برقابة حكومية بصفة أساسية، ولن يدفعها المكلف من تلقاء نفسه لو وجد فرصة للتهرب منها، صحيح يوجد من يدفعها عن رضا واختيار وبطيب نفس بل يتقرب بها إلى الله، ولكنهم قلة ؛ لاعتقاد كثيرين أنه فرضت اعتباطا أو نحو ذلك. V- يجدر القول ههنا بأن علماء الشريعة فرقوا بين نوعين من المال من جهة ولاية التحصيل، حيث جعلوا ولاية تحصيل الزكاة للسلطات الحاكمة في الأموال الظاهرة(Y0)، وأما الأموال الباطنة فلمكلف ولاية في بذلها، مع الاتفاق أنها تجزئ متى التى أعطيت للسلطات الحاكمة(YOY)، وأما في الضريبة

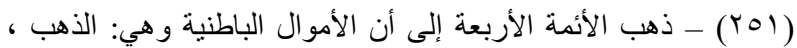

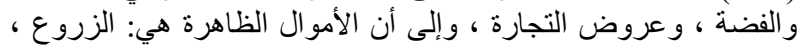

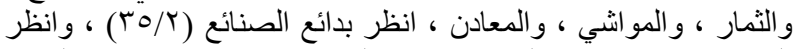

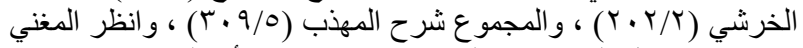

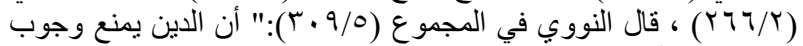

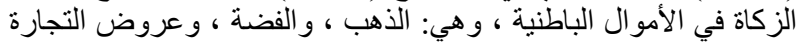

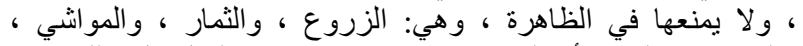

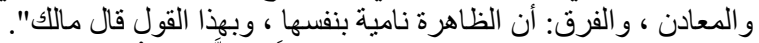

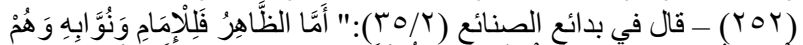

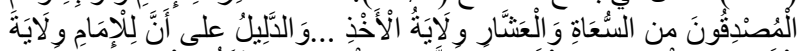

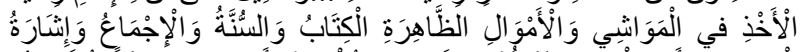

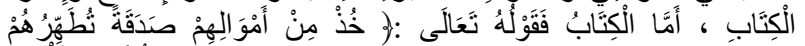

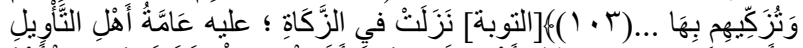

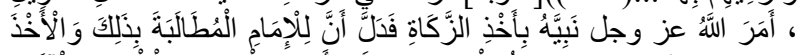

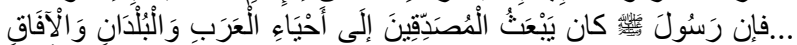

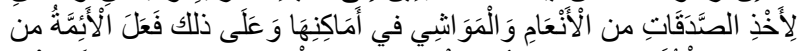

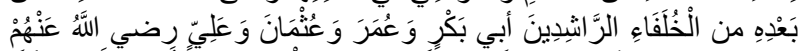

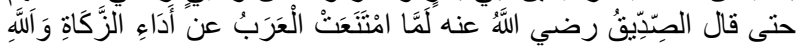

ضريبة قيمة مضافة، لأنها حينئذ ليست ضربية قيمة مضافة بل ضريبة دخل. وبهذا أكون قد أتيت على أهم ما يمكن أن يقال في صدد الحديث عن الضريبة البديلة التي يمكن أن تفرض على المهني، وهي الضريبة التي تفرض على الدخل، بشرط فرضها على دخول الآخرين، وإلا فهو فرض غير عادل. المبحث الثالث: الفرق بين الضربية والزكاة. هنالك فروق عديدة بينهما، وهي مذكورة في عدة بحوث، ومقالات، وسأذكرها على نحو مختصر، ولكن سأركز على الأثر الاقتصادي، نظرا لاهتمامي البالغ باه منطلقا من الفقه الإسلامي، ولدى النظر نجد الفروق الآتية: - ت ن 1- الزكاة فريضة إلهية، أما الضربية فتلزم بها

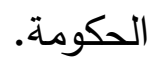
Y- الزكاة محددة المقدار، أما الضريبة فليست كذلك، بل تترك لتقديرات الجهات الحاكمة. r- الزكاة في أموال محددة، أما الضرببة فليست كذلك، بل تترك لتقديرات الجهات الحاكمة. ع- الزكاة لها مصارف (بالتعبير المعاصر موجهة لتمويل) جهات محددة، أما الضريبة فليست كذلك، بل تترك لتقديرات الجهات الحاكمة. ه- الزكاة في كفة وتحريم الربا في كفة أخرى قرينان محفزان للاستثمار، ونافعان على المستوى الاقتصادي، ويقللن من البطالة، ويضبطان التضخم بصفة دائما، أما الضريبة فتختلف آثارها بحسب 
فولاية التحصيل مناطة بالسلطات مطلقا ؛ ولا يليها المكلف إلا طبقا لنص قانوني، ووفق شكليات محددة . وإلا فلا يبرأ منها.

هذه أهم الفروق بين الزكاة والضريبة، وليس هذا

البحث مخصصا للحديث على نحو مفصل عن هذا الشأن، ولكن يحسن أن أذكر أن اقرب نوع من أنواع

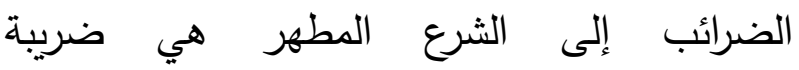

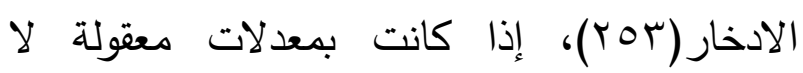

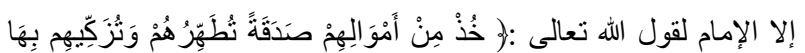

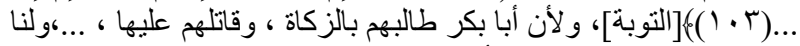

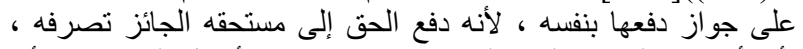

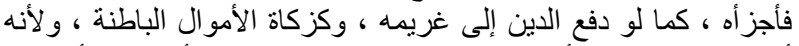

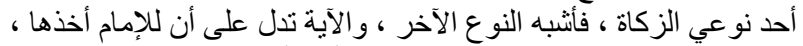

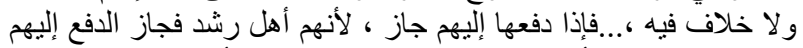

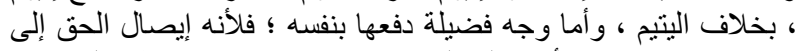

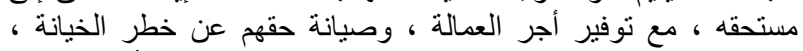

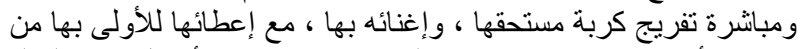

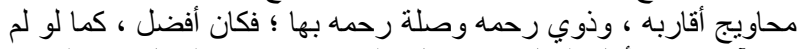

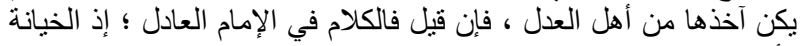

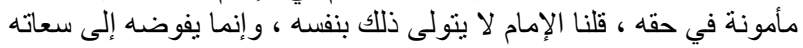

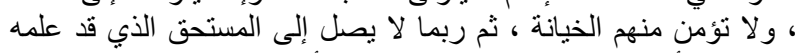

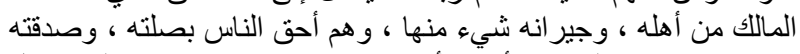

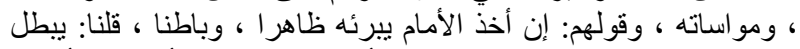

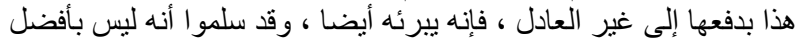

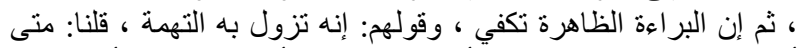

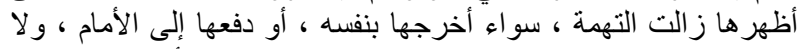

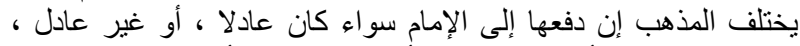

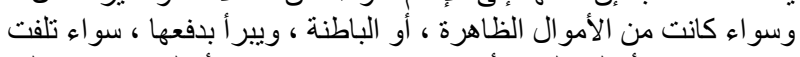

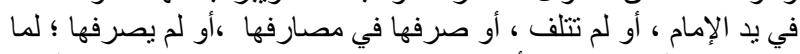

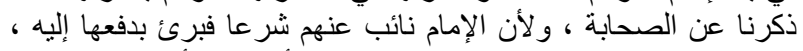

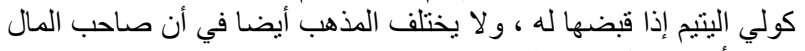
يجوز أن يفرقها بنفسه" انتهى.

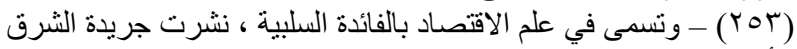

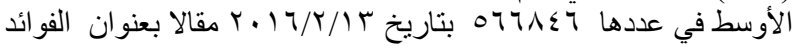

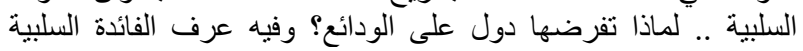

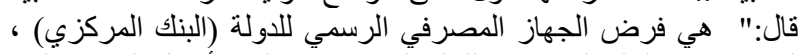

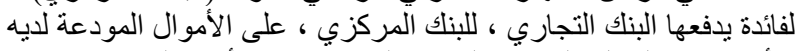

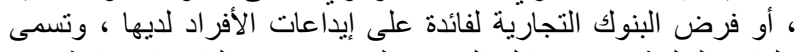

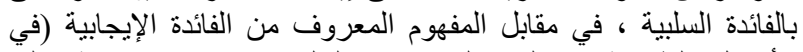

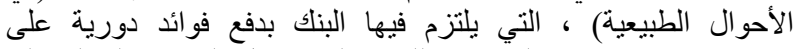

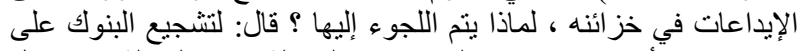

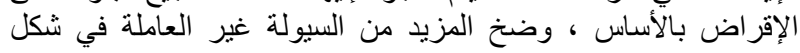

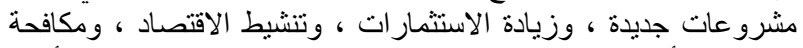

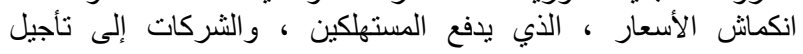

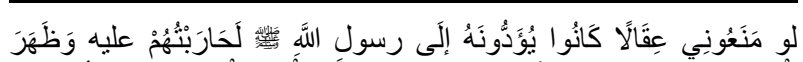

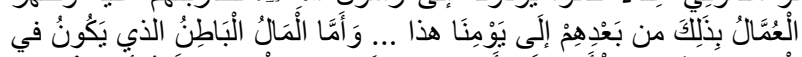

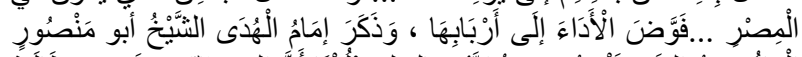

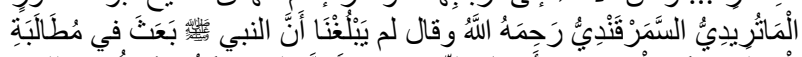

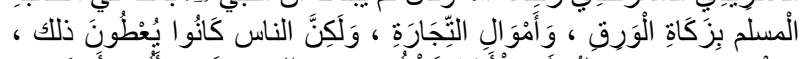

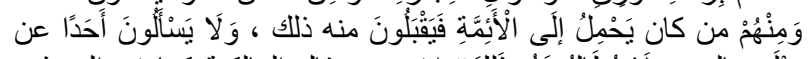

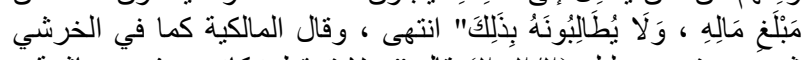

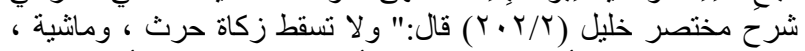

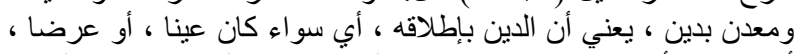

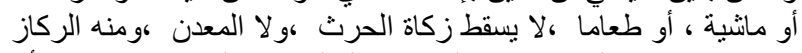

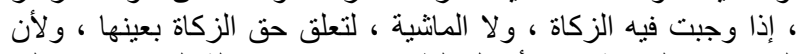

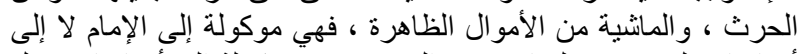

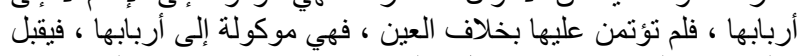

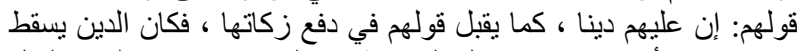

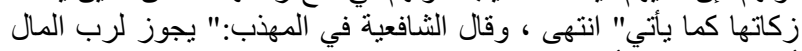

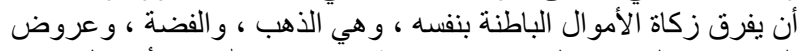

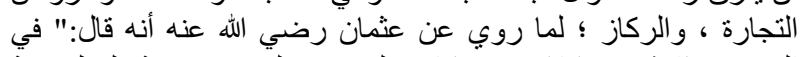

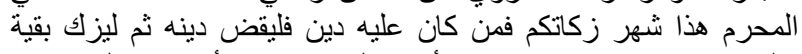

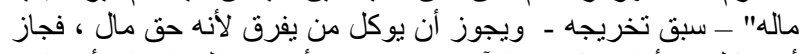

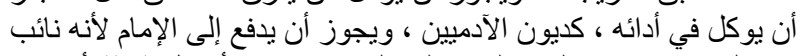

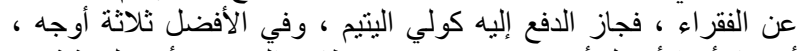

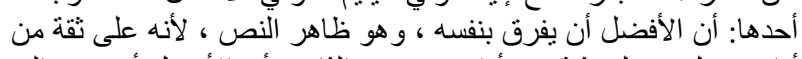

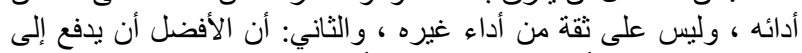

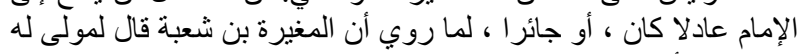

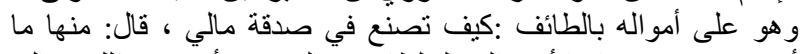

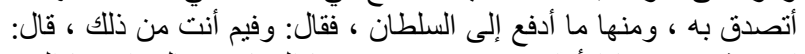

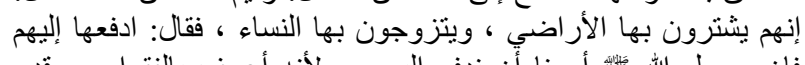

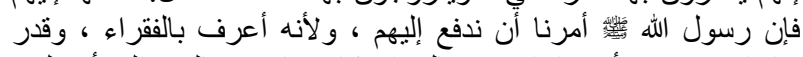

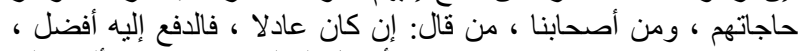

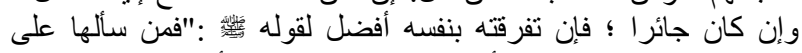

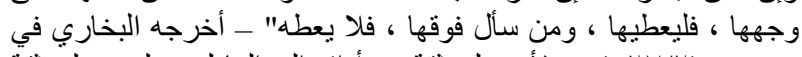

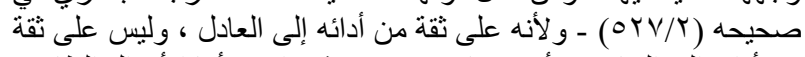

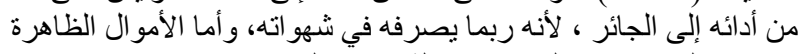

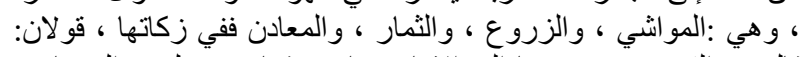

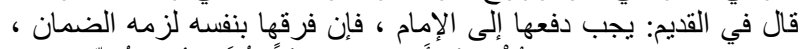

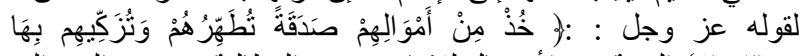

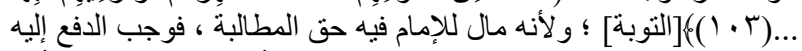

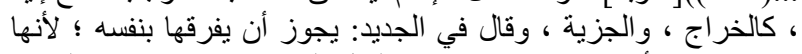

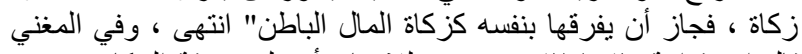

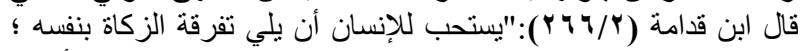

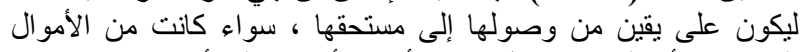

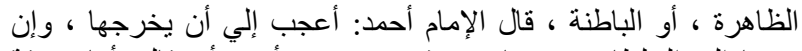

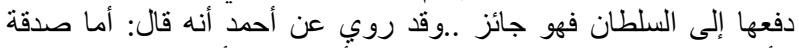

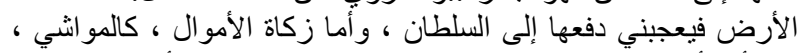

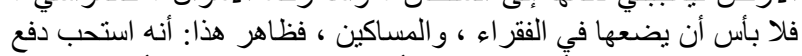

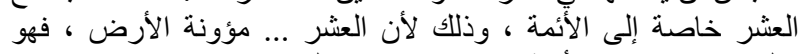

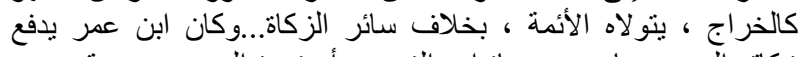

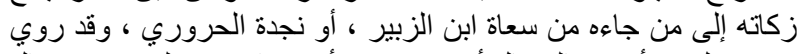

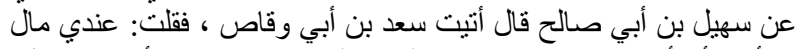

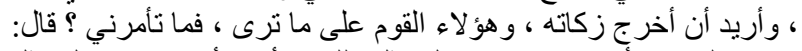

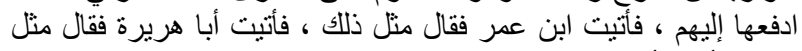

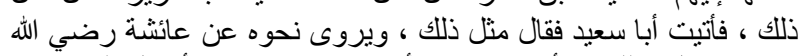

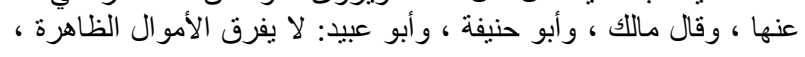


المرجوة لبني البشر لاى سن القوانين، ولله الأمر من قبل ومن بعد.

بهذا أكون قد أتيت على أهم ما يمكن أن يقال في صدد الحديث عن فرض الزكاة في دخول المهنيين، وتجاوزت ذلك للحديث عن فرض الضرببة ؛ باعتبارها بديلا مقترحا لمساهمة المهنيين لمصلحة الاقتصاد الوطني، وآن ذكر الخاتمة، وأهم النتائج، سائلا الله تعالى حسن الختام. الخاتمة وأهم النتائج. الخاتمة وأهم النتائج. بحمد الله تعالى تم في هذه الدراسة بيان مختصر يتعلق بالزكاة وهو الفصل الأول بتمامه ؛ إذ بينت معنى الزكاة، وأركانها، وشروط كل ركن، وإذا كان من جديد هنالك فهو يتعلق بتصنيف شروطها ؛ إذ جعلتها شروطا تتعلق بالركن، وهذا تصنيف حادث، غير أنه أقرب منالا، وأقعد ؛ لأنه يربط الشرط بركنه، ولهذا كانت أركان الزكاة بشروطها هي: ا . باذلها "المكلف"، وشرطه الإسلام، والحريـة . r. المبذولة إليه وهو: مستحقها "مصرفها"، وشرطه قيام وصف من الأوصاف الثمانية المذكورة في آية الصدقات، وألا يكون من آل محمد لَ. r. المال المبذول "الأموال الزكويـة"، وشرط ذلك: أ- أن يبلغ المال الزكوي المملوك نصابا. ب- أن يحول عليه الحول في غير الزروع، والثمار والمعدن، فزكاتهما بعد الحصاد والتنقية.
تتجاوز الزكاة ؛ لأنها حينئ تشبه الزكاة وليست هي على أي حال. وقبل أن أنهي هذه الدراسة، أجزم أن الأخذ بالمبادئ الاقتصاد الإسلامي كفيل برفع كل الضرر الذي يمكن أن يتعرض له الاقتصاد، وتحقيق أعظم المنافع

مشترياتهم ، و استثمار اتهم ؛ بانتظار احتمالية تدني الأسعار بشكل أكبر في

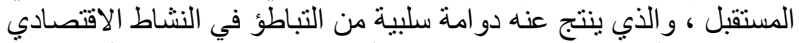

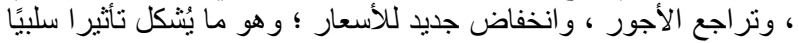

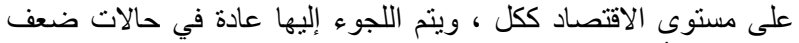

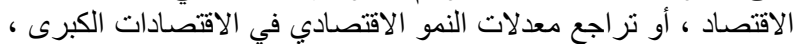

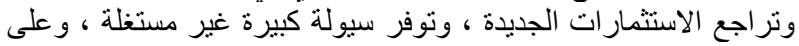

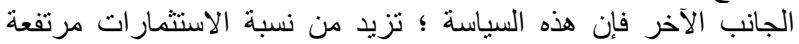
المخاطرة ، ومن أمثلة على تطبيق الفائدة السلبية أن البنائك المركزي

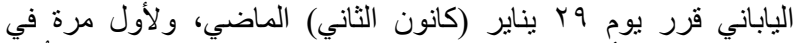

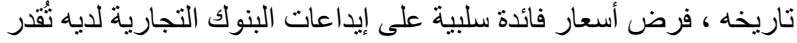

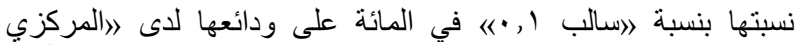

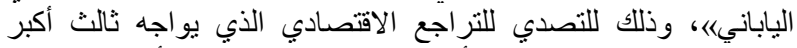

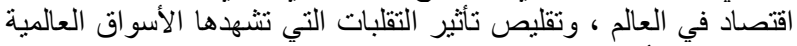

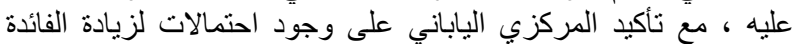

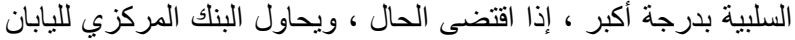

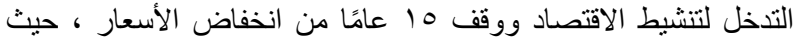

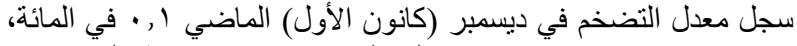

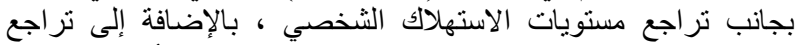

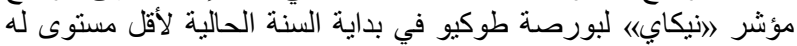

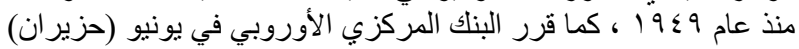

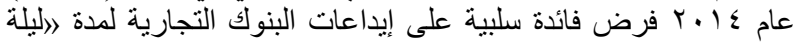

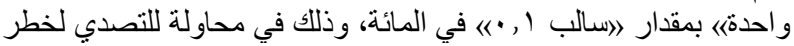

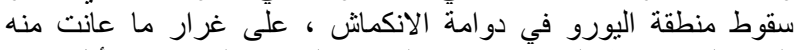

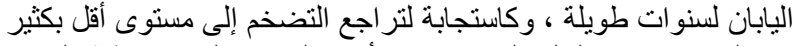

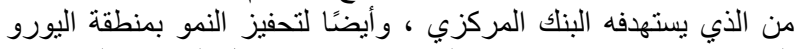

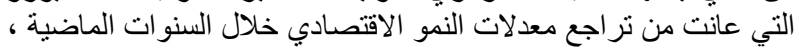

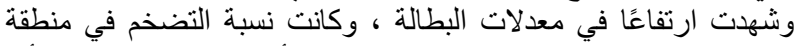

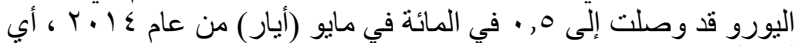

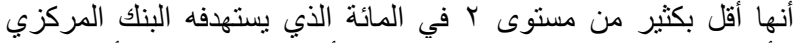

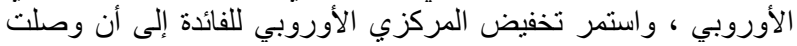

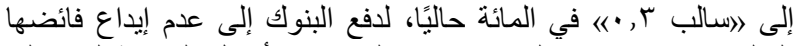

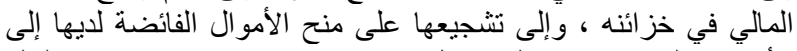

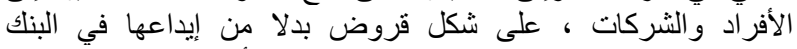

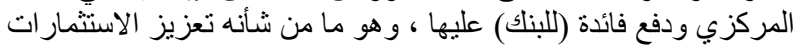

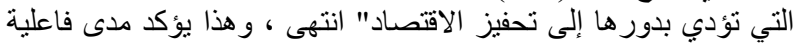

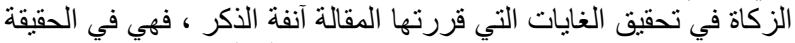

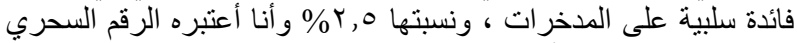

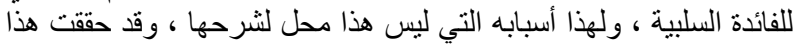

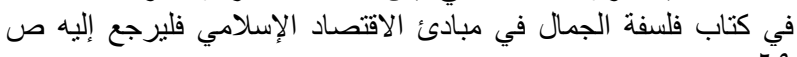


نقدي حال عليه الحول وهو عنده ؛ فيزكيه كما يزكي المسلم زكاته في النقد المدخر لو حال عليه حول، بوصفه مالا مدخرا، هذا هو مقتضى الفقه

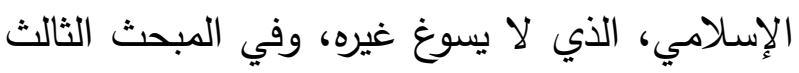

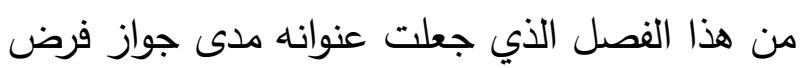
الضريبة على المهني، تحدثت عن مفهوم الضريبة، والمنطلقات العقائدية "الفكرية" التي تحكم فرضها، وأوضحت أن فرض الضربية ينطلق منطقيا من الطبيعة الفكرية التي يؤمن بها النظام، وليست أمرا اعتباطيا، وأن النظم التي تحكم، تضع قواعدها المنسجمة مع فكرها نصب عينيها، وهي تقرر أي

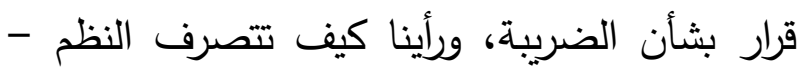
على اختلافها - بشأن الضربية، فهناك النظام الإقطاعي، الذي تقوم بنيته على النشاط الزراعي

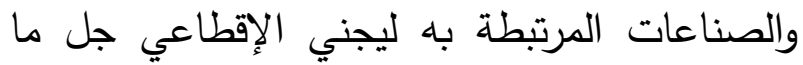

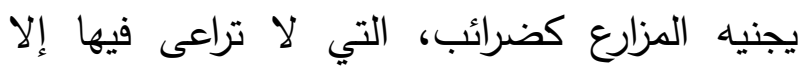
مصالح الإقطاعيين وأسيادهم، ولا يترك من الثروة لإنيك بيد الأغلبية إلا القدر الذي يجعلهم قادرين على لإعلى

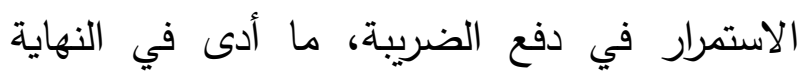
للقضاء على النظام الإقطاعي، ليحل مكانه النظام

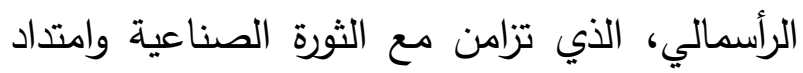
النشاط التجاري وتوسع كبير في نطاق المدن

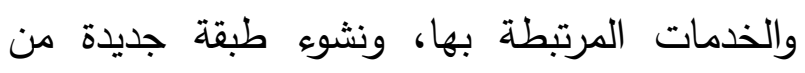

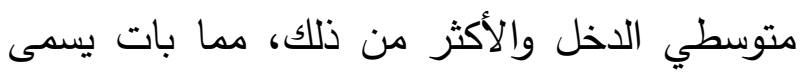

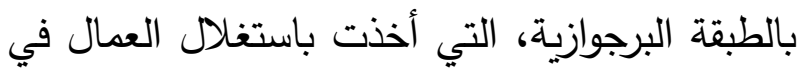

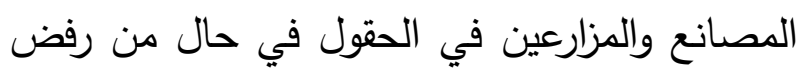

ت- أن يكون الملك تاما، فلا تتعلق به مستحقات

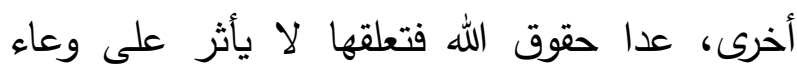

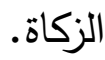
ث- أن يخرج عن دورته الاقتصادية بالإرادة، فانن

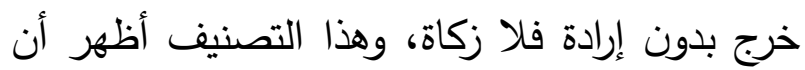
قيام شرطي العقل والبلوغ في المكلف ليس هما مناط الوجوب، وأن الثرط المناسب للحكم هو خروج المال عن دورته الاقتصادية بالإرادة، فمتى تم إخراج المال

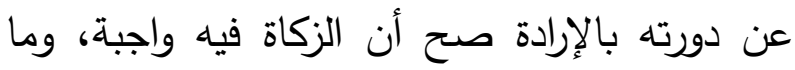
ليس كذلك لا تجب فيه الزكاة، لأن الزكاة تطهير للمال، وبتعبير آخر ضريبة تعطيل المال، وليس مناسبا فرضها على من لم تقم به إرادة في هذا

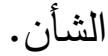
وأما الفصل الثاني فهو محل العناية وفيه تحدثت عن تعريف المهني، وإمكانية تخريج المهنة طبقا لفقه

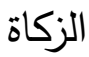

وأقوال الفقهاء بشأنه، وأوضحت أنه لا يوجد أصل

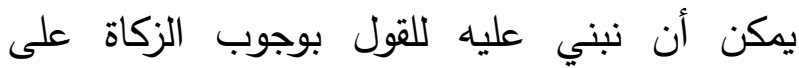

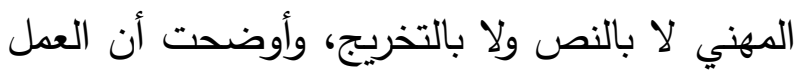
المهني قديم قدم البشرية، ولو وجب عليه شيء من الفراض الشرعية من جهة كونه مهني، لتم ذكره سواء

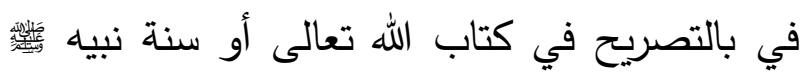
أو بالتلميح، وهذا لم يكن، فدل ألا زكاة على المهني بوصفه صاحب مهنة، وأن الزكاة لو وجبت عليه فإنها تجب عليه في حالة ادخار شيء حال عليه الحول من النقد فحينها يزكي بوصفه مالكا لنصاب 
بعدم تدخل الدولة، وبعدم فرض ضرائب إلا في

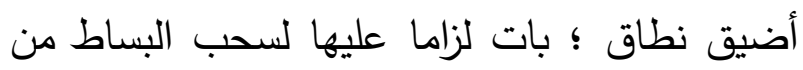

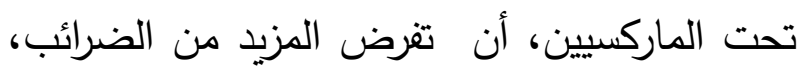

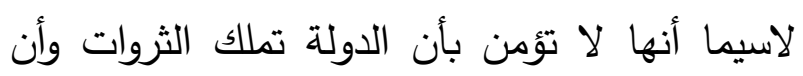

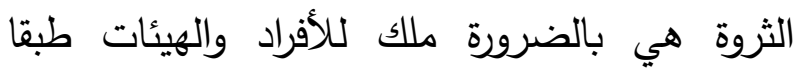
للقانون، وظهرت تزامنا مع هذا الفكر قواعد تحكم فرض الضريبة، لأنها في الأساس فرضت لهان لإيجاد

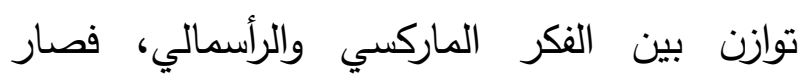
للضريبة شروطا لتعتبر جيدة ولتحقق غاياتها "وظائفها"، ومن أهم تلك الشروط أن تتصف بتُبئ بالعدالة

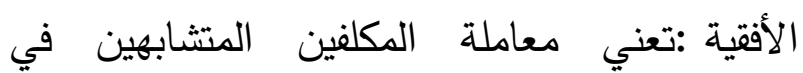
الظروف معاملة متشابهة، وبالعدالة الرأسية: تعني معاملة المكلفين المختلفين في الظروف معاملة ملتهابها مختلفة، وهذا ما تم التأكيد عليه بعد أن بينت حكم فرض الضريبة في الإسلام ؛ إذا بينت جواز ذلك

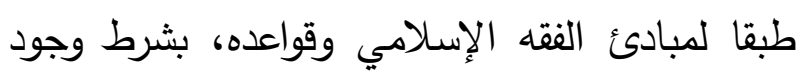

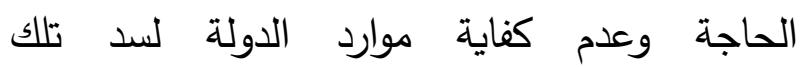
الاحتياجات، بالإضافة لسنها بمعدلات تجيزها

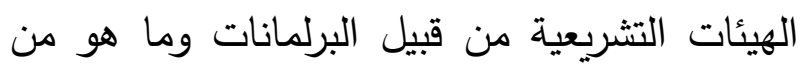
هذا القبيل، من الجهات التي تراعي كافة الظروف للى سنها، وتقوم بالتدقيق لدى التنفيذ، فلا يكون

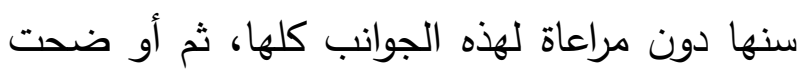

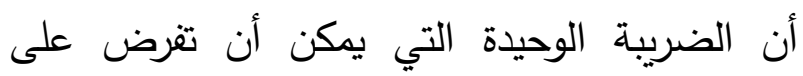
المهني، هي ضريبة الدخل، ولا يقبل فرضها عليه ؛

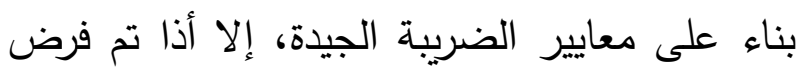
ضريبة الدخل على الآخرين طبقا لقاعدة العدالة
تدخل الدولة في الاقتصاد، ولتكون الثروة بيد الناس،

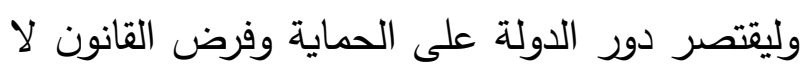

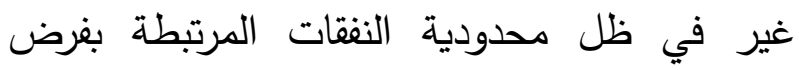
القانون والحماية، ما يعني القليل من الضرائب، ما يعني تخلي الدولة عن دورها في الرعاية، ما زاد من

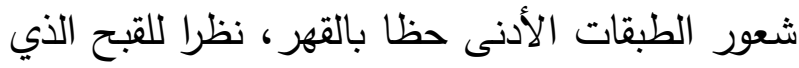
عبر عنه الرأسماليون، وتجاهلهم التام لحقوق العمال

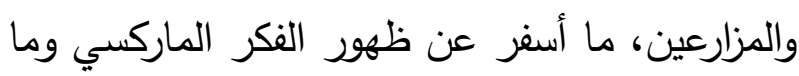
اقترحه من قيام النظام الثيوعي، والاشتراكي، اللذان

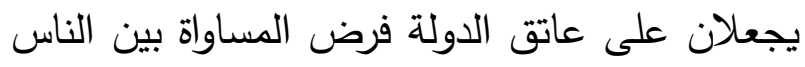

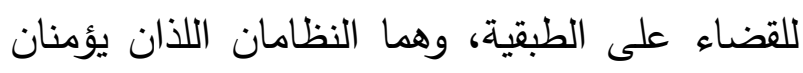
بأن للدولة الحق في التصرف بكل الثروات، وبكل عوامل الانتاج، وبعدم وجود ملكية للأفراد أو لغيرهم من الهيئات إلا للدولة، وهذا الفكر الذي تؤمن به وديه

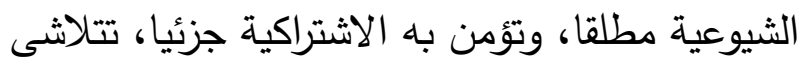

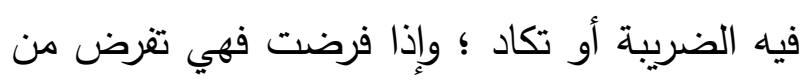

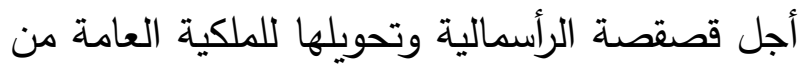
الطريق الخلفي، حتى تزول نهائيا، تلك المثل التي تزعمها الماركسية، ضرب الرأسمالية في مقتل، لانيا، لانيل سيما بعد نجاح سيطرة الماركسيين على عدة بلدان، ما معل الخطر الكبير يحدق بالرأسمالية والرأسماليين، ما أسفر عن نظم مختلطة هي التي تحكم في معظم بقاع الدنيا الآن، لتصبح معظم الدول رأسمالية اشتراكية، وترفع شعار دولة الرفاهية، التي هي بالضرورة دولة رعاية، وحماية، ما يعني أن الرأسمالية التي تؤمن بالملكية الشخصية، وتؤمن ودن 
إرواء الغليل في تخريج أحاديث منار السبيل - محمد ناصر الدين الباني - المكتب الإسلامي لخي الإنصاف في معرفة الراجح من الخلاف على مذهب الإب الإسي الإمام أحدد - علي بن سليمان المرداوي - دار إحياء التراث. بحث في طبيعة وأسباب ثروة الأمم واسمه الثائع

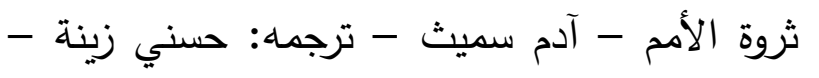
معهد الدراسات الاستراتيجية البحر الرائق شرح كنز الدقائق - زين الدين بن

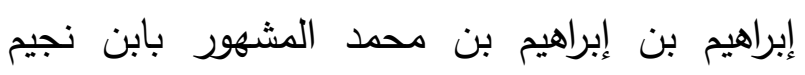
الحنفي - دار المعرفة. بدائع الصنائع في ترتيب الشرائع - علاء الدين ابي بكر بن مسعود الكاساني الحنفي - دار الكتاب

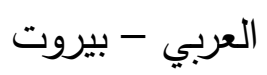

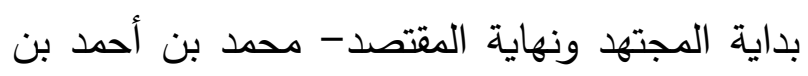
محمد بن رشد - دار الفكر - بيروت تبيين الحقائق شرح كنز الدقائق - فخر الدين

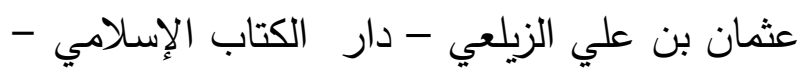

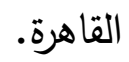
التعريفات - علي بن محمد الجرجاني - دار الكتاب العربي.

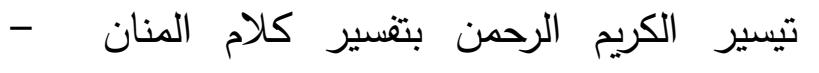
عبدالرحمن بن ناصر السعدي - ت: : عبدالرحمن لويحق المطيري - دار السلام للنشر والتوزيع. تلخيص الحبير - أحمد بن علي بن حجر العسقلاني - ت عبدالله هاشم اليماني
الأفقية المذكورة آنفا،وأما ما يتصل بفرض ضريبة

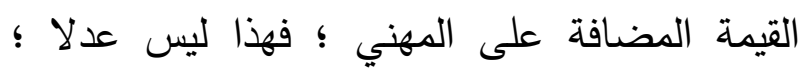
لأنها بالضرورة تصبح ضريبة دخل، وقد ذكرت سبب ذلك، وعليه لا يقبل فرضها عليه، لأنه يصبح

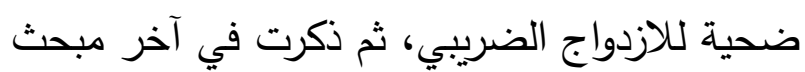
أهم الفروق بين الضريبة والزكاة، وختمته بقولي "أجزم أن الأخذ بالمبادئ الاقتصاد الإسلامي كفيل

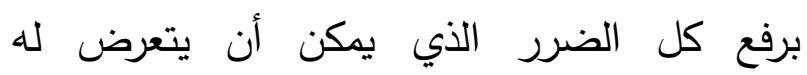
الاقتصاد، وتحقيق أعظم المنافع المرجوة لبني البشر لبر لبرض لاى سن القوانين، ولله الأمر من قبل ومن بعد". وهذه خير خاتمة سائلا الله حسن الختام.

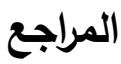

فهرس المراجع والمصادر مرتبة ترتيبا الف بائي باسم الكتاب ثم المؤلف ثماند المحقق ثم دار النشر أكتفي بذكر الكتب فقط (تهمل باست الإصلاح الاقتصادي - شريف دلاور - المكتبة الأكاديمية. الاقتصاد الوضعي والاقتصاد الإسلامي نظرة

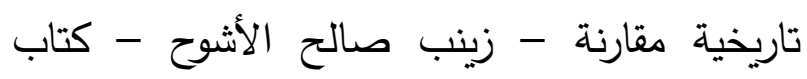

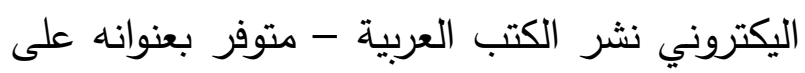
الإنترنت 
جامع البيان عن تأويل آي القرآن المشهور باسم زكاة الشركات في الفقه الإسلامي- حنان عبدالرحمن تفسير الطبري - محمد بن جرير الطبري - طبع أبو مخ - دار المأمون - عمان

سنن ابن ماجه م - محمد بن يزيد القزويني

ت:محمد فؤاد عبدالباقي - دار الفكر - بيروت بن بندئ

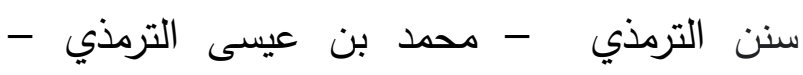
ت:أحمد شاكر - دار إحياء التراث

سنن الدار قطني - علي بن عمر الدارقطني البغدادي - ت: عبدالله هاشم يماني - دار المعرفة عمدي سياسة المال في الإسلام - عبدالله جمعان السعدي لماني - مكتبة المدارس - الدوحة الإسة الثرح الكبير - السيد أحمد الدردير أبو البركات ت:محمد عليش - دار الفكر - بيروت.

صحيح الترغيب والترهيب - محمد ناصر الدين الألباني - مكتبة المعارف.

صحيح مسلم - مسلم بن الحجاج النيسابوري- ت الدباني محمد فؤاد عبدالباقي - دار احياء التراث: العادات والتقاليد في العهود الإقطاعية- علي الزين - دار الفكر الحديث. فتح الباري - أحمد بن علي بن حجر العسقلاني دار المعرفة

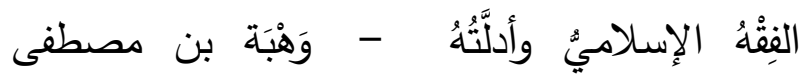

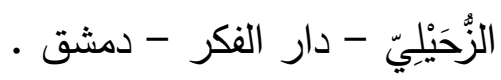

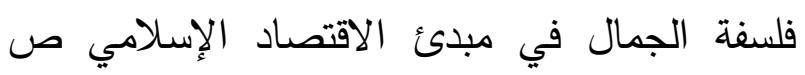

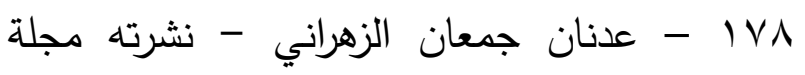
الاقتصاد الإسلامي، وهو كتاب الكتروني يمكن
تفسير الطبري - مار الفكر - بيروت بن بن جرير الطبري - طبع الجامع الصحيح المسند من حديث رسول الله وسننه

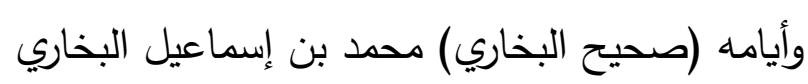
- ت: مصطفى ديب البغا - دار ابن كثير

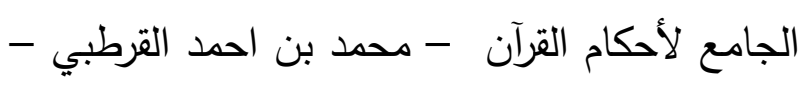

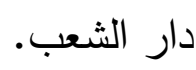
حاشية الثرح الكبير - محمد عرفة الدسوقي - مار دار الفكر • الخرشي على سيدي خليل - محمد بن عبد الله الخرشي - دار الفكر الدر المختار - - محمد بن علي بن محمد الحِصْني المعروف بعلاء الدين الحصكفي الحنفي - ت:عبد

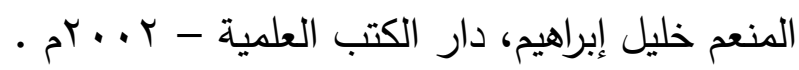
دور الدولة في الاقتصاد- حمزة الببلاوي - دار

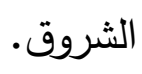
الذخيرة - شهاب الدين أحمد بن إدريس القرافي دار الغرب رأس المال - كارل ماركس - ترجمة راشد البرادي كتبة النهضة المصرية. رسالة أبي زيد القيرواني- عبدالله بن أبي زيد القيرواني - دار الفكر. الروض المربع - منصور بن يونس البهوتي مكتبة الرياض الحديثة 
مصنف عبدالرزاق - عبدالرزاق بن همام الصنعاني - ت:حبيب الرحمن الأعظمي- الككتب الإنسلامي

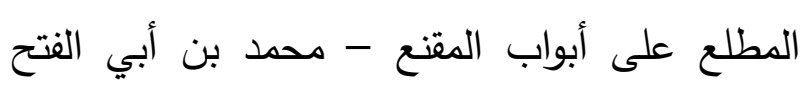
البعلي الحنبلي - ت:محمد بشير الإدلبي - الدكتب

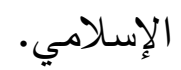

معالم السنن شرح سنن أبي داوود- حمد بن محمد الخطابي البستي - ت:عبدالسلام عبدالثافي - دار الكتب العلمية كبيروت. معجم المصطلحات السياسية والدبلوماسية والاقتصادية- حسام الدين جاد الرب - دار العلوم.

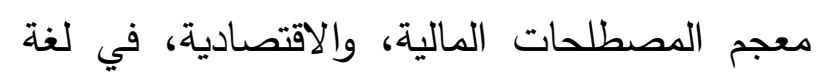

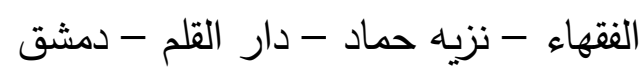
معجم مقاييس اللغة - أبو فارس أحمد بن فارس - دمن

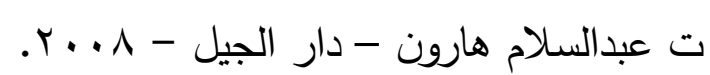
المغني - عبدالله بن أحمد بن قدامة المقدسي دار الفكر - بيروت

الدفردات في غريب القرآن - أبو القاسم الحسين بن محمد المعروف بالراغب الاصفهاني - مكتبة نزار الاز - مكة .

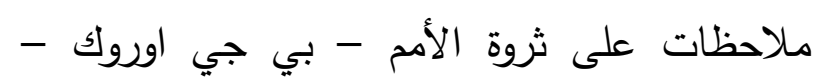
ترجمه معين الإمام - مكتبة العبيكان.

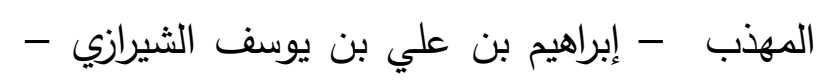

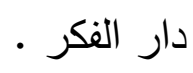

المواعظ والاعتبار بذكر الخطط والآثار المعروف بالخطط المقريزية - أحمد بن علي الدقريزي - دار الكتب العلمية
تنزيله من موقع مركز أبحاث فقه المعاملات الإسلامية،

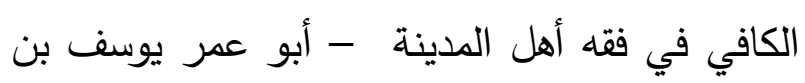
عبدالله بن عبدالبر القرطبي - دار الكتب العلمية .بيروت

كثاف القناع عن متن الإقتاع - منصور بن يونس البهوتي - دار النكر - بيروت.

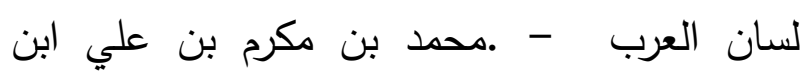

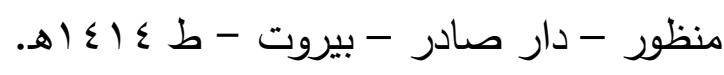
ماذا حدث للثورة الدصرية - جلال امين - دار

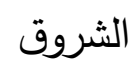
المجموع شرح المهذب - أبو زكريا يحيى بن شرف النووي - دار الفكر - بيروت

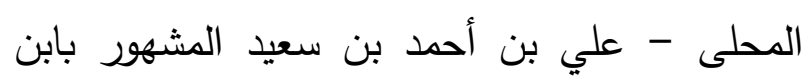
حزم الظاهري - ت: لجنة إحياء التراث - دار الآفاق الحديثة - بيروت مذاهب فكرية معاصرة - محمد قطب - دار الثروق مسند أحمد - أحمد بن محمد بن حنبل - ت أحمد محمد شاكر - دار المعارف الدستصفى- محمد بن محمد الغزالي - دار الكتب العلمية مشارق الأنوار على صحاح الآثار في شرح غريب الحديث -عياض بن موسى اليحصبي المالكي ت:إبراهيخ شمس الدين - دار الكتب العلمية. مصنف ابن ابي شيبة - ت:كمال يوسف الحوت -

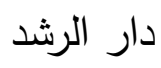


$1 \leqslant$.

القول المبين في حكم الزكاة على المهنيين؟ والضريبة عليهم كبديل؟ تأصيل ودراسة

الموسوعة الفقهية الكويتية- وزارة الأوقاف في دولة النظم المالية في الإسلام - قطب إبراهيم محمد الهيئة المصرية العامة للكتاب

$$
\text { الكويت. }
$$

النظام المالي الاسلامي في العصر الاول للدولة العباسية - عبدالله جدعان السعدي - رسالة دكتوراه-

النجوم الزاهرة في ملوك مصر والقاهرة - أبو المحاسن يوسف بن تغري بردة - دار الكتب جامعة الأزهر

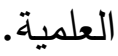

الهداية شرح بداية المبتدي - علي بن أبي بكر نصب الراية - عبدالله بن يوسف الحنفي الزيلعي المرغيناني - المكتبة الإسلامية. ت:محمد يوسف البنوري - دار الحديث - مصر تم الرجوع لعشرات المقالات، والمواقع، والدوريات. هI TOV

النظم الإقطاعية في الشرق الأوسط في القرون الوسطى- إبراهيم علي طرخان - دار الكتاب

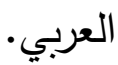




\title{
The Obvious Opinion regarding the Ruling of Zakat on Professionals? And tax them as an alternative? Fundamental Study
}

\author{
DR. Adnan Al-Zahrani
}

\begin{abstract}
God protect it, made reference in all its works and acts for the Quran and the Sunnah; as the seventh article of the Basic Law of Ruling which is issued by the Royal Decree No. A / 90 dated 27/8/1412 AH states: "The ruling in the Kingdom of Saudi Arabia derives its authority from Quran and Sunnah of the prophet and they are the rulers over this law and all state laws", and the eighth article states: "The ruling in the Kingdom of Saudi Arabia is based on justice, mutual consultation "Shura", and equality in accordance with Sharia law."

This study is an application based on this approach, which is depending on Quran and Sunnah, and based on justice, Shura, and equality between people according to the provisions of Sharia. Whilst scientific research is one of the legitimate ways which paves the way for exchanging opinions and providing advice; the researcher in his capacity as a practitioner, and has experience in this regard, and has something to add about a new topic like this which is classified within the jurisprudence of contemporary issues, especially in our country, may God protect it, considering that applications related to tax are characterized as contemporary issues, and it is still on its way to take shape and clarity; Therefore, the researcher tries to present a study in this regard because of the inaccuracy he observed in the implementation and the lack of perception according to his point of view, in which it may contribute to rationalizing the work, and leaves an influence on the development of this sector, as this presented study does not determine the principles concerning what is imposed on the practitioner, it rather determines what is beyond that where it draws attention that economic policies are nothing but a reflection of the ideological attitudes and ideas which those who determine those policies believe in, in addition to that steps in various areas should be launched in harmony with those ideological and intellectual trends.

This study determines that imposing zakat on the practitioneras a man of a profession is incorrect and there is no supporting evidence for it and no scholar has said something like that in our entire jurisprudential heritage. As for imposing tax on the practitioner, it is something that is justifiable, but with certain conditions. The most important of which is that it should be characterized by horizontal justice: It means treating similar taxpayers alike, and vertical justice: It means treating different taxpayers in circumstances differently. This was emphasized during the study, as the study showed that the only tax that can be imposed on the practitioner is the income tax, and it is not accepted to impose such tax, in accordance with good tax standards, unless the income tax is imposed on other similar professions which is in accordance to the aforementioned horizontal justice rule. As for the imposition of value-added tax on the professional, this is not fair; because it necessarily becomes an income tax, and I mentioned the reason for that, and accordingly it is not accepted to be imposed on the practitioner, because he becomes a victim of double taxation, which is discussed in this study.

I conclude this research sincerely for the sake of Allah the Almighty, His Messenger, the Muslim rulers and Muslim people.

Prayers and blessings be upon his prophet, household and companions.

Concluded at the end of Ramadan $1441 \mathrm{AH}$.

Lawyer: DR. Adnan Al-Zahrani
\end{abstract}

